\title{
Markets, Migrants and Institutional Change: The Dynamics of China's Changing Huji System, 1978-2007
}

\author{
By \\ Jason Young
}

\begin{abstract}
A thesis
submitted to Victoria University of Wellington

in fulfilment of the requirements for the degree of

Doctor of Philosophy

in Political Science
\end{abstract}

Victoria University of Wellington

2010 


\section{Abstract}

This research seeks to understand how institutions of governance are adapting to the changing conditions arising from the large scale internal migrations as a result of the growth of the market economy in China. The primary focus is explaining continuity and change in the formal institutional arrangements of the huji system over the period of study (1978-2007). During China's 'static decades' (late 1950s - late 1970s), internal migration was heavily restricted, regulated and controlled by state planning and state allocation of public resources to the point where internal migration was for most limited to political migrations. The mechanism for controlling population movements was and largely still remains the 'household registration/huji/hukou system' but since the policy of 'reform and opening', the number of people involved in spontaneous, non-sanctioned and 'outside the plan' economic migrations has grown rapidly. Most scholars agree that there are now well over 140 million nongmingong (rural workers), residing in Chinese cities without 'urban household registration'.

This research acknowledges the politico-economic dynamics of this contemporary increase, specifically the reintroduction of market economics, integration into the global economy and the geopolitical dispersion of foreign capital, and seeks to investigate how huji management has been adapted to the challenge of 'temporary' residents in urban areas. Liberal economic arguments view the huji system as a hangover of the command economic functioning of central planners and an impediment to economic growth and development. However, the sustained period of rapid economic growth over the period of study suggests the role of huji management in development needs to be reconsidered. This study seeks to ascertain what role the huji system has played in this development and explain how and why it has survived and adapted this revolutionary upheaval.

Data is generated from hukou statistics, laws, directives and regulations as well as migration, urbanisation and economic indicators to demonstrate the exact nature of the relationship between domestic economic development, the movement of migrants and changes in law, government policy and regulations regarding people's movement and residency. From this data the major changes are presented, including liberalisation of labour migration, some liberalisation of hukou transfer, decentralisation of hukou decision-making, and a general prioritising of the modern values of efficiency and equality, though far more the former than the latter. From these findings a model of formal institutional change in China's huji system is developed outlining a dynamic process of change that occurs due to a gap between informal institutional practices and formal institutional arrangements brought about by changing socio-economic conditions and an evolving institutional culture. The research gives us a better understanding of the dynamics of institutional change in a transitional society, contributes to institutionalist studies of change and provides well needed insight into the institutional foundations of the Chinese developmental state. 


\section{Acknowledgements}

I would like to firstly thank my primary supervisor, Professor Xiaoming Huang, without who it is unlikely this project would have gotten off the ground. His encouragement, guidance and critical eye drove me to complete the work and his own impressive career and work ethic provided me with a model of academia. My secondary supervisors, Dr John Leslie and Dr Kate McMillan, also provided consistent and professional advice and academic critique. I am grateful to have had supervisors with such a wide range of expertise. I would also like to generally thank all the staff of the Political Science and International Relations (PSIR) programme at Victoria University for making time to discuss my work and for providing guidance and motivation in the endeavour. Special thanks go to Dr Robert Deuchars for sparking my interest in the topic and to Professor Elizabeth McLeay for her commitment to graduate students in our department. A special acknowledgement is also necessary for the other graduate students working on projects at the same time who made completing the work a lot more enjoyable.

Secondly, special thanks go to those institutions that helped fund this research. The Victoria University of Wellington PhD Scholarship made this project possible and gave me the time and energy to dedicate myself to the endeavour. Such a generous scholarship made the project a reality and kept food on the table, so to speak. The New Zealand Asian Studies Society kindly provided me with a scholarship to conduct fieldwork in Beijing without which the project could have never been completed. China University of Political Science and Law (CUPL) in Beijing hosted me in the 2007/2008 summer and I am grateful to them for allowing me access to their library and research databases as well as providing me with office space. Special thanks are needed for those academics and students at CUPL who firstly made me welcome in Beijing and secondly provided me with critiques of my own conceptual understanding of the huji institution. Special thanks also go to the PSIR programme at Victoria for providing me with tutoring employment and to the New Zealand Contemporary China Research Centre whose founding was timely, encouraging and supportive.

Lastly, I would like to thank my family for their support and understanding throughout. My wife's encouragement and hard work kept me motivated and my daughter provided me ample inspiration to complete the task. Writing this thesis has been an experience I will never forget and one that has given me the opportunity to constantly learn for which I am most grateful. Throughout the long project many people and organisations have given their time and support. Whilst there are too many to mention in this short acknowledgement I hope I have given due thanks to those organisations and people that have been central to the completion of the work. Any omissions, inaccuracies or inconsistencies are entirely my own mistake. 


\section{Table of Contents}

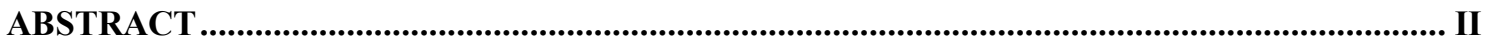

ACKNOWLEDGEMENTS ........................................................................................................III

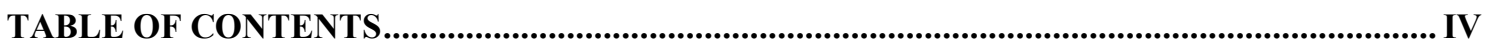

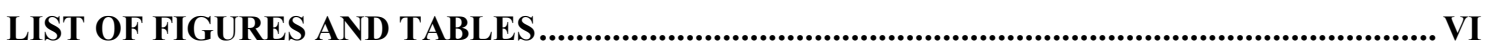

INTRODUCTION ……........................................................................................................... 1

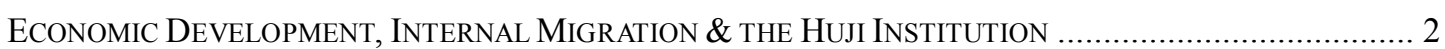

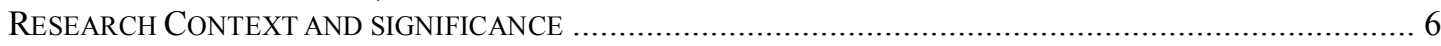

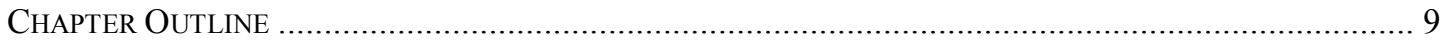

1 THEORETICAL FRAMEWORK AND METHODOLOGY ...................................................14

1.1 THEORETICAL MODELS OF ECONOMIC MIGRATION ........................................................... 14

1.2 ECONOMIC EXPLANATIONS FOR THE GROWTH OF THE MigRANT POPULATION IN ChinA .........17

1.3 THE LIMITATIONS OF ECONOMIC EXPLANATIONS .............................................................25

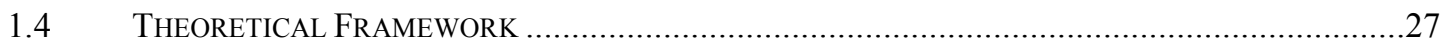

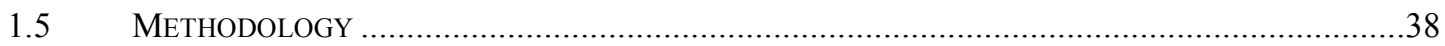

2 ECONOMIC DEVELOPMENT AND INTERNAL MIGRATION ...........................................41

2.1 ECONOMIC DEVELOPMENT AND THE REFORM ERA …...........................................................41

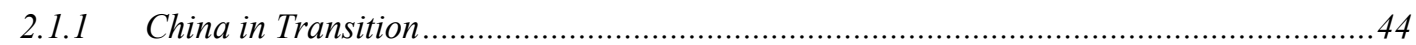

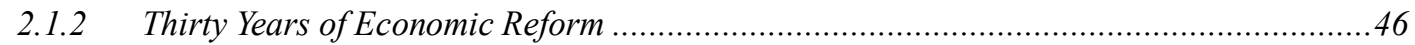

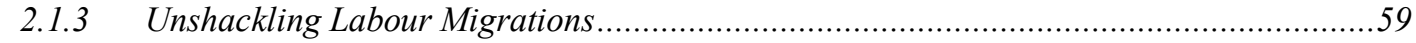

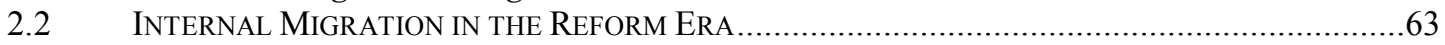

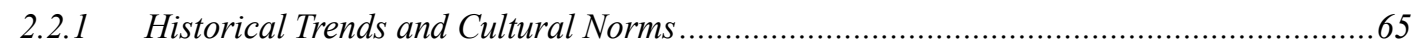

2.2.2 The Demographics of Contemporary Internal Migration.....................................................68

2.2.3 Nongmin Migrants: Discrimination, Abuse \& Exploitation?........................................... 71

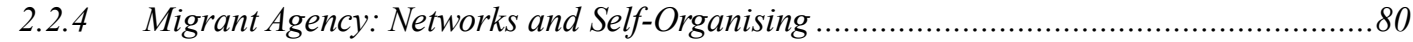

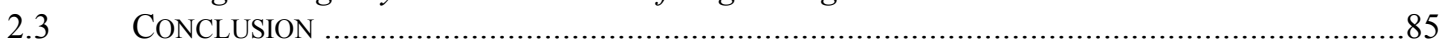

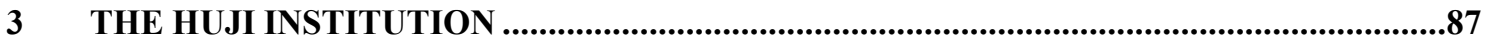

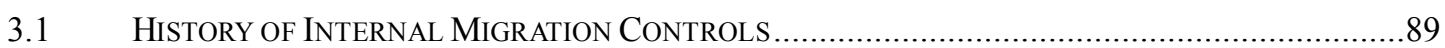

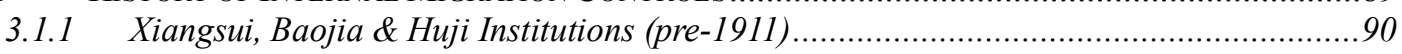

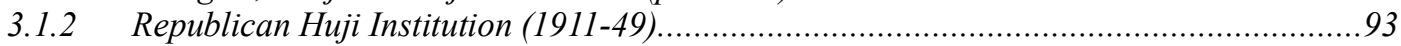

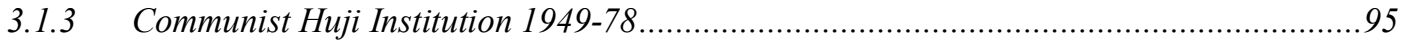

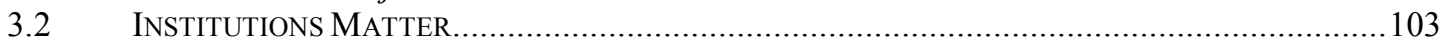

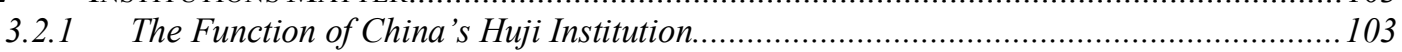

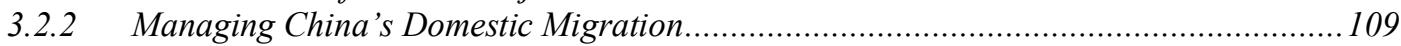

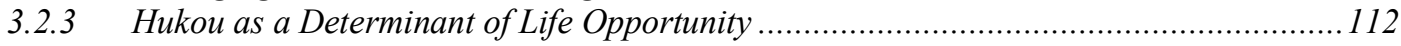

3.3 INSTITUTIONS ADAPT AND ENDURE - BUT WHY AND How? ...........................................117

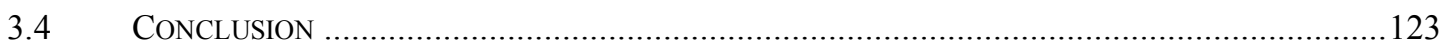

4 CASE 1: INSTITUTIONAL CHANGE AT THE NATIONAL LEVEL ..................................124

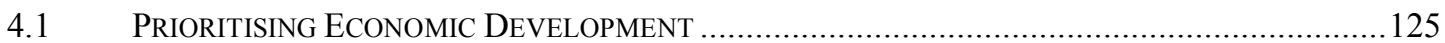

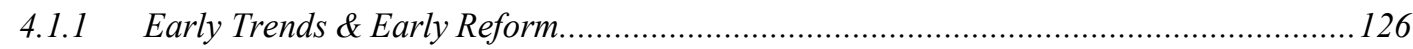

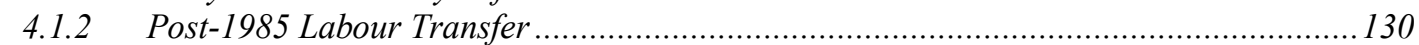

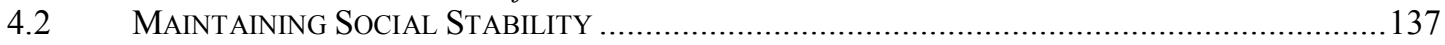

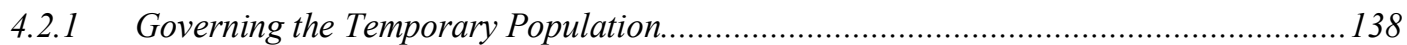

4.2.2 Permanent Hukou \& Hukou Transfer ........................................................................... 143

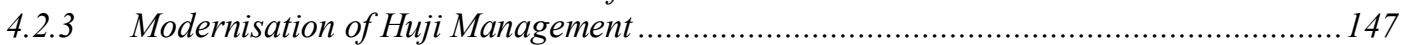

4.3 Managing \& ReStRICTING Migration \& Urbanisation.............................................. 150

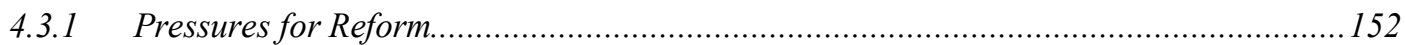

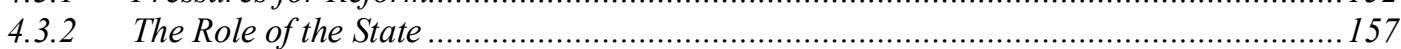

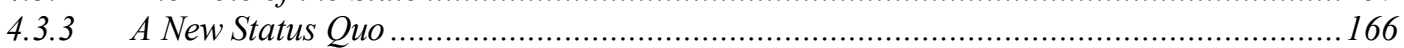

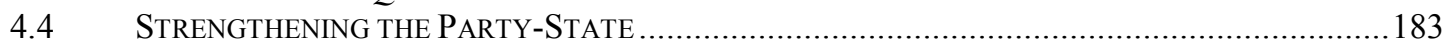

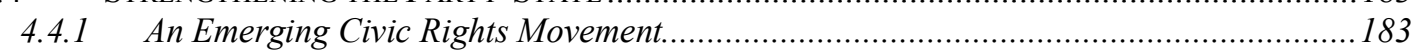

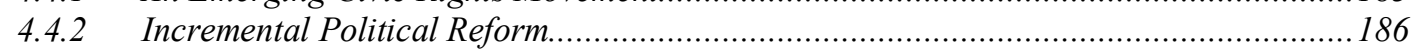

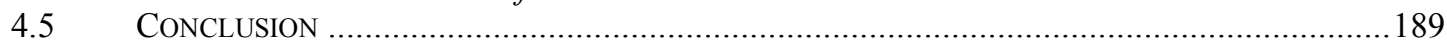




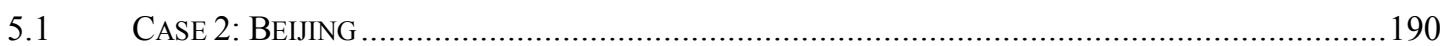

5.1.1 The Beijing Huji Population ....................................................................... 191

5.1.2 Beijing Hukou Transfer........................................................................................ 194

5.1.3 Beijing Non-Huji Residents ............................................................................ 202

5.1.4 The Institutional Challenge ............................................................................... 213

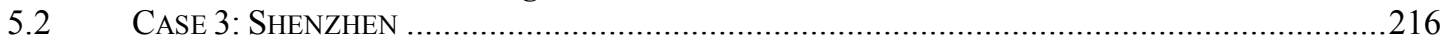

5.2.1 Migrant City .............................................................................................. 217

5.2.2 Emerging Huji Regulations ............................................................................... 221

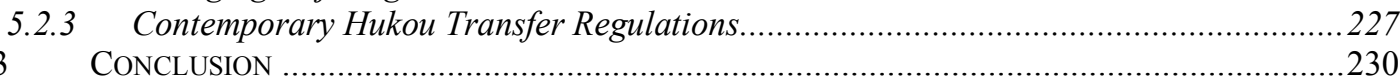

5.3

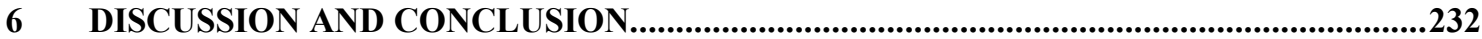

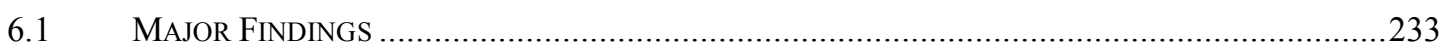

6.1.1 Major Findings from Case 1: China .......................................................................2234

6.1.2 Major Findings from Cases $2 \& 3$ : Beijing and Shenzhen .....................................245

6.1.3 Continuity and Change: Major Findings .....................................................................252

6.2 A Model of Institutional CHAnge in ChinA’s Huji System .........................................260

6.2.1 Formal Institutional Arrangements \& Enforcement in Practice ....................................263

6.2.2 Actor Interpretation \& Behaviour................................................................. 266

6.2.3 Architect Interpretation \& Behaviour .................................................................2 270

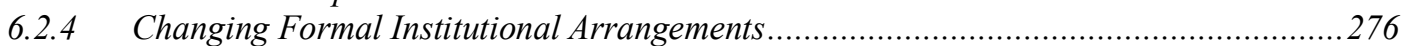

6.3 THEORETICAL SIGNIFICANCE ..................................................................................27

6.3.1 Economic Models of Migration, Solinger and Wang ...........................................2278

6.3.2 Theories of Institutional Change..........................................................................2280

6.3.3 Research Shortcomings and Future Research Questions .........................................284

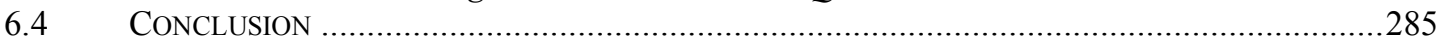

APPENDIX I - TIMELINE OF INSTITUTIONAL CHANGE ................................................289

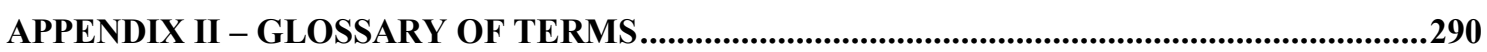

Notes on THE UsE of ChIneSE NAMES AND TERMS: .......................................................293

APPENDIX III - RELEVANT NATIONAL LAWS, REGULATIONS AND DIRECTIVES........294

APPENDIX IV - RELEVANT BEIJING \& SHENZHEN LAWS, REGULATIONS \&

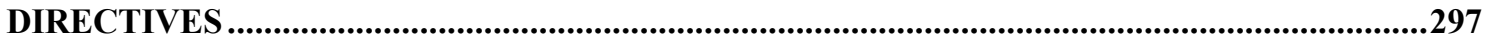

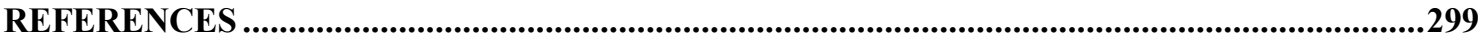




\section{List of Figures and Tables}

Figure 1: Gross Industrial Output of State and Non-State Enterprises.....................................................

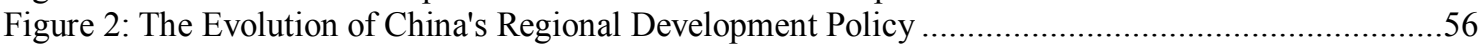

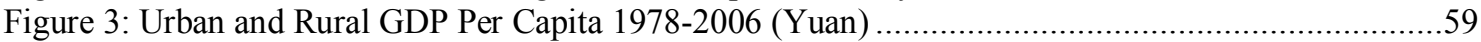

Figure 4: Percentage of Population in Rural and Urban Areas (1978-2006) .......................................61

Figure 5: Growth of the Inter-County Floating Population in China, 1982-2000 ..................................69

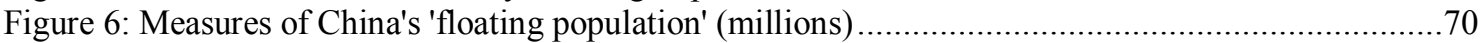

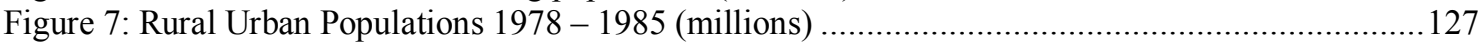

Figure 8: Employed Persons by Three Strata Industries 1978-1985 ................................................127

Figure 9: Gross Domestic Product by Three Strata Industries 1978-1985 (\%) ..................................... 127

Figure 10: Employed Persons by Three Strata Industries 1978-2007 (\%)..........................................132

Figure 11: Employed Persons by Three Strata Industries 1978-2007 (millions) ……….........................133

Figure 12: Employed Persons in Rural and Urban Areas 1978-2007 (\%) ............................................134

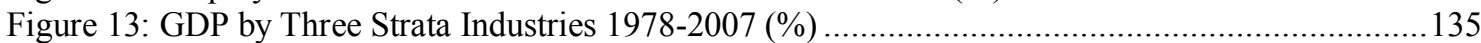

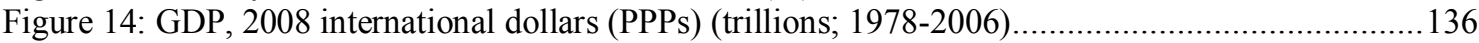

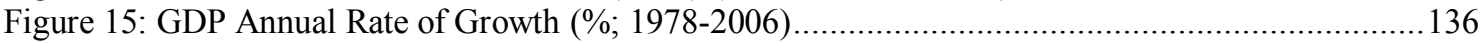

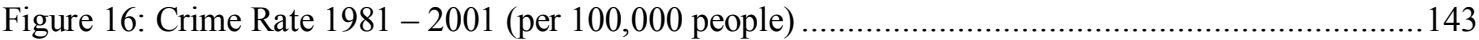

Figure 17: Digitalised Huji Management - Location of the Non-Agricultural Population .......................150

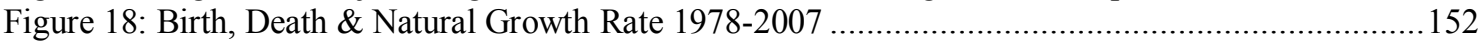

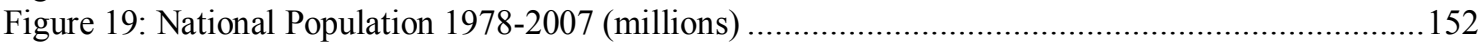

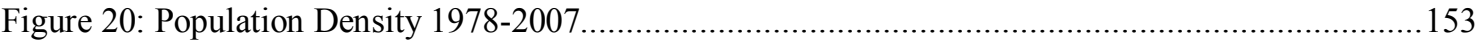

Figure 21: Per Capita Net Income of Rural and Urban Households 1978 - 2006 ..................................153

Figure 22: Real Difference in Per Capita Net Income of Rural and Urban Households 1978 - 2006 ....... 154

Figure 23: Per Capita Net Income of Rural Households as a Percentage of the Per Capita Net Income of

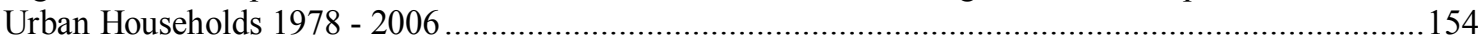

Figure 24: Rural Urban Proportion of Investment in Fixed Assets....................................................... 155

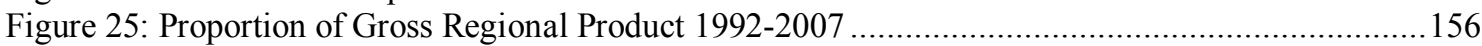

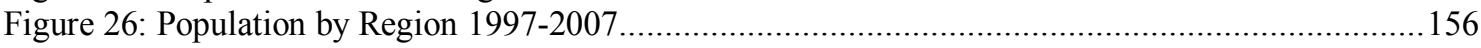

Figure 27: Proportion of Gross Regional Product Per Capita 1992-2007 ………................................. 156

Figure 28: National Floating Population 1980-2005 (millions) ................................................................ 159

Figure 29: Nongzhuanfei Settlement Quotas and Population Plans for Small Cities and Towns (1998). 164

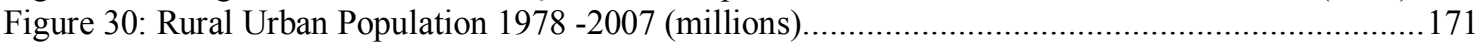

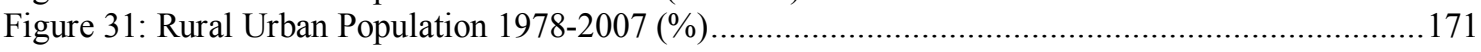

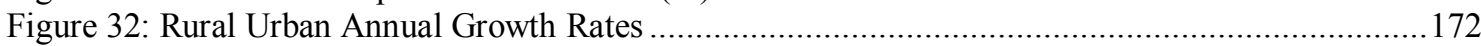

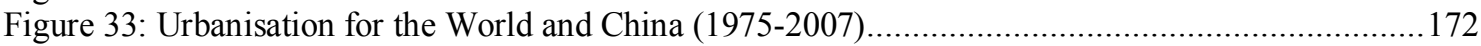

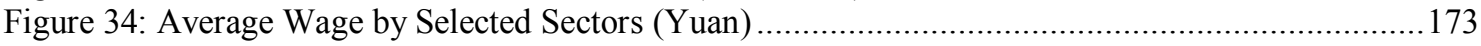

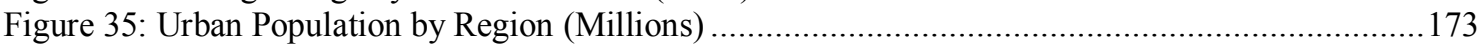

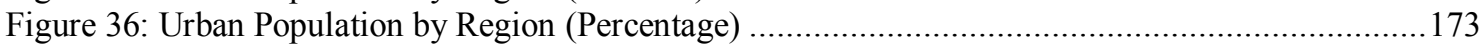

Figure 37: Non-Hukou Holders as a Percentage of the Regional Population 1996-2007........................174

Figure 38: Non-Hukou Holders as a Percentage of the Regional Population 2000, 2005 ........................174

Figure 39: Regional Population of Non-Hukou Holders in $2000 \& 2005$ (millions) ............................... 175

Figure 40: Permanent Hukou Location of Non-Hukou Population by Regions in 2000 (millions) ...........175

Figure 41: Permanent Hukou Location of Non-Hukou Population by Regions in 2000 (\%)...................176

Figure 42: Urbanisation by Non-Agricultural Hukou over 31 Regions (2007) ....................................176

Figure 43: Registered Agricultural \& Non-Agricultural Population by Region in 2007 (millions)..........177

Figure 44: Registered Agricultural \& Non-Agricultural Population by Region in 2007 (\%) ...................177

Figure 45: Non-Agricultural and Agricultural Population in Cities by Region (2007, total 619m).........178

Figure 46: Non-Agricultural and Agricultural Population in Towns by Region (2007, total $762 \mathrm{~m})$.......179

Figure 47: Non-Agricultural and Agricultural Population in Counties by Region (2007, total 689m) ....179

Figure 48: Distribution of City Population across Varying City Sizes (millions; total 619m) ................180

Figure 49: Non-agricultural Hukou Status in Cities 3-16 Million (110 million total)............................181

Figure 50: Non-Agricultural Hukou in Cities Smaller than 3 Million (509 million total)........................181

Figure 51: Average Wage of Staff \& Workers by Urbanisation in 31 Regions.....................................181

Figure 52: Average Wage of Staff \& Workers by Non-Agricultural Hukou in 31 Regions.........................182

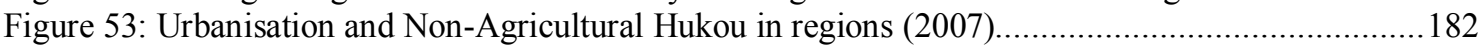

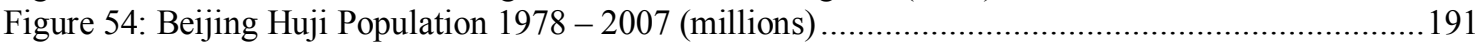

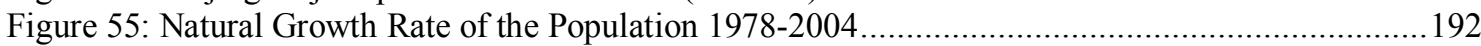

Figure 56: Natural Change in the Beijing Huji Population (2003-2007).................................................... 193

Figure 57: Natural Change Agricultural \& Non-Agricultural Beijing Huji Population (2003-2007).......193

Figure 58: Natural and Non-Natural Real Change in the Beijing Huji Population (2003-2007) ..............195 
Figure 59: Non-Natural Real Change in the Beijing Huji Population 2003-2007 (Inward - Outward

Transfer)

Figure 60: Inward \& Outward Agricultural \& Non-Agricultural Hukou Transfer in Beijing 2003-2007 195

Figure 61: Beijing Huji and Non-Huji Population 1978-2007 (millions)......................................205

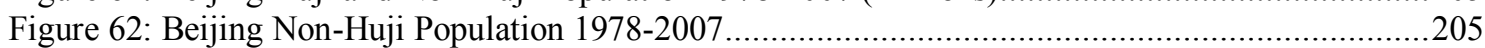

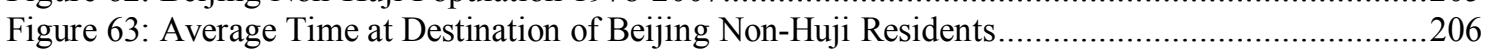

Figure 64: Comparison of Non-local \& Huji Employment Type in Beijing (\%, 2000, 2005) ...............209

Figure 65: Consumable Items per 100 Households by Hukou Status in Beijing ..............................210

Figure 66: Beijing Rural Urban Populations 1978-2007 (millions) .............................................211

Figure 67: Rural and Urban Workforce in Beijing (millions).....................................................212

Figure 68: Beijing Urban Employed Population by Type of Ownership 1978-2007 (millions) .............212

Figure 69: Foreign Direct Investment in Shenzhen 1978-2008 (trillion, USD)...............................217

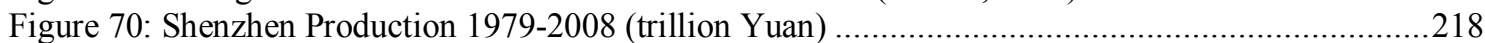

Figure 71: Shenzhen Production Growth Rate 1980-2008 (\%) ….................................................218

Figure 72: Shenzhen Huji Population 1979-2007 ......................................................................218

Figure 73: Non-Huji Population in Shenzhen 1979-2007 ...................................................220

Figure 74: Huji and Non-Huji Population in Shenzhen 1979-2007 ................................................222

Figure 75: Location of Huji and Non-Huji Populations in Shenzhen in 2007 (millions) .......................221

Figure 76: A Model of Institutional Change...........................................................................263

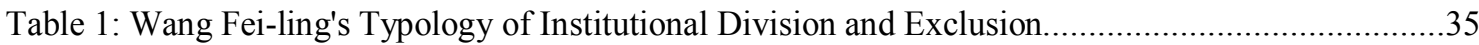

Table 2: Fermentation and Formation of the Huji Institution 1949-1957..........................................96

Table 3: Selected Summary of the 1958 PRC Hukou Registration Regulations...................................97

Table 4: Type of Urban Migrant as Defined by Hukou Status .................................................. 112

Table 5: Four Categories of Urban Workers .............................................................................. 131

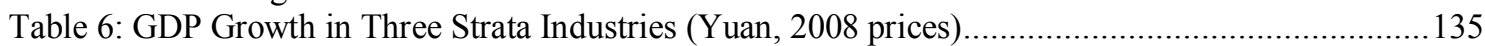

Table 7: MPS Temporary Resident Regulations..................................................................... 142

Table 8: MPS Directives to Local Government................................................................................ 144

Table 9: Shanghai Public Security Bureau Hukou Related Tasks .................................................... 145

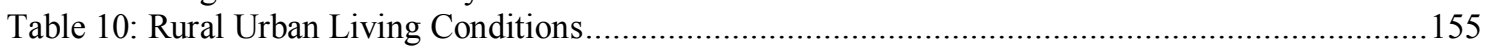

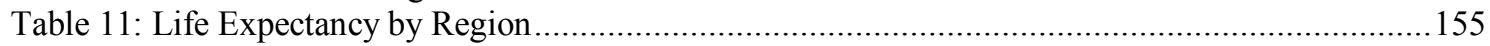

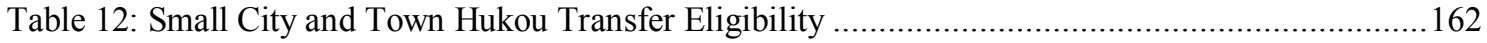

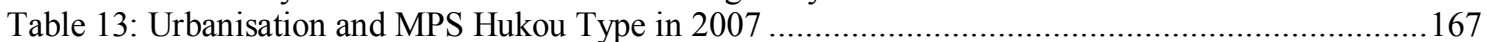

Table 14: Urbanisation and MPS Hukou Type by Region in 2007 ................................................178

Table 15: Government Departments Involved in Beijing Hukou Transfer Decisions...........................196

Table 16: Eighteen Categories of Hukou Transfer into Beijing.................................................. 197

Table 17: Meritocratic Hukou Transfer Categories and Related Regulations in Beijing .....................200

Table 18: Hukou Type of the Non-Huji Beijing Population (2005 \& 2006) ........................................207

Table 19: Community Type at Destination of the Floating Population in Beijing...............................207

Table 20: Huji and Non-Huji Population by Beijing District 2005 - 2007 (thousands).......................208

Table 21: Comparison of Huji and Non-Huji Population Employment in Beijing ..............................210

Table 22: Economic Growth Created by Nongmingong in Selected Industries in Beijing (2003) .........213

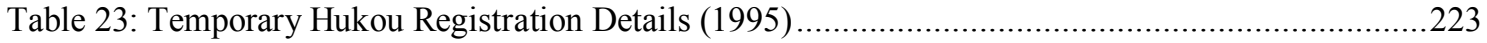

Table 24: Shenzhen Blue Chop Hukou Applicant Conditions (1995)..........................................225

Table 25: Shenzhen Inward Hukou Transfer Conditions (1995) .........................................................226

Table 26: Shenzhen Inward Hukou Transfer Categories (2007) ......................................................228 


\section{Introduction}

"Anhui is a large and populous province, an excellent source of labor. By 2000, when the central government started the experiment of changing taxes into fees and charges, there were 10 million surplus laborers in the Anhui countryside, 40 percent of the rural labor force. Agriculture has become a losing enterprise. The peasants had toiled on the soil for untold generations and had looked on the soil as the source of life itself, but now the soil had become a burden. Thus an army of peasants turned their backs on the soil and marched into the city. In the city, however, all the benefits of the urban residents such as the newly invented "basic insurance," "medical insurance," "housing benefits," and so on were beyond the peasants' reach. Since the "residence permit" forbade them permanent status in the city, the vast army of incoming peasants were doomed to remain migrants in the city."

The above section from Will the Boat Sink the Water? The Struggle of Peasants in $21^{\text {st }}$ Century China, captures many of the important elements of China's 'age of migration:'2 the dismantling of the communal farming system; the uncovering of rural underemployment and the freeing up of rural labourers; the mass movement of nongmin ${ }^{3}$ or 'peasants' into urban areas in search of work, (China's nongmingong) ${ }^{4}$ and the ongoing importance of China's 'huji institution' 5 for providing permanent residential status in cities and thus access to associated public and private services. With well over 130 million rural migrant labourers and many rural families now residing in China's once impenetrable cities, China is experiencing an unprecedented 'age of migration' with acute institutional implications. The following sections introduce the puzzle of the limited reform and overall stability of China's age-old huji institution. Increased migration is both a product of the marketization of labour, particularly rural labour, and limited liberalisation of the huji system. Explaining how, why and to what degree the huji institution has changed over the last three decades is the primary focus of this research.

\footnotetext{
${ }^{1}$ Guidi Chen and Chuntao Wu, Will the Boat Sink the Water? The Struggle of Peasants in 21st-Century China, trans. Hong Zhu (HarperCollinsPublishers, 2006). p.199.

${ }^{2}$ Zai Liang, "The Age of Migration in China," Population and Development Review 27, no. 3 (2001).

3 农民 'rural resident' often translated as 'peasant': this category is institutionally imposed at birth based on familial lineage (see Glossary of Terms).

4 农民工 - literally 'agricultural resident labourers' but often translated as 'rural workers'. The term 农民 (nongmin) categorizes and politically defines rural residents. When these rural residents move to the city most cannot become 市民 (shimin or city residents) but rather remain nongmin living and working in the city. These nongmin are termed nongmingong to distinguish them from nongmin in rural areas and shimin. 5 户籍制度 huji zhidu or 'household registration system/institution'.
} 


\section{Economic Development, Internal Migration \& the Huji Institution}

China's age of migration shows great similarities to the historical urbanisation and industrialisation trends of developed economies. Euro-American experiences during their industrial revolutions and high periods of urbanisation provide credible baselines for the Chinese experience. The starkest distinction however, comes not from the massive disparity in domestic population sizes but from the institutional tools central and local authorities utilise to manage the internal migration and settlement rights of Chinese citizens. When comparing China's Lewis Transition experience (see chapter 1) to the historical experience of developed countries and the experience of other developing states, China's hukou/huji institution stands out as a unique feature of the contemporary Chinese polity. Explaining why this once pre-modern institution has survived the establishment of the modern state, in particular the liberalised economic and migratory trends of the reform era provides well needed insight into China's politico-economic reforms and unique development model. Explaining how the institution has evolved provides well needed insight into theories of institutional change in transitional economies.

The stunning economic development of the reform era (1978-2007) has revolutionised economic and social life in China and led to the formation of a new institutional category of nongmingong labouring in the urban Chinese economy. Farmers now sell their produce in urban stalls at market prices and watch as their children leave in droves to work in the globalised secondary industries of the economic boom areas of Shenzhen, the Pearl River Delta, and Guangdong to name but a few. Like so many of the waves of internal migration and urbanisation brought on through industrialisation, modernisation and a move from premodern predominantly agrarian economic arrangements to modern economic arrangements characterised by high levels of urbanisation and a large 
secondary and tertiary industry labour market, China's 'age of migration' has profound implications not only socially and economically, but also for the institutional arrangements of the Chinese bureaucracy. Economic conditions have created an environment conducive for rural labour migration and the loosening of China's once rigid huji regulations has dismantled some of the barriers set up to prevent China's urban areas being swamped by 'excess rural workers'.

Reform remains limited however as settlement with entitlement in urban areas is still strictly controlled. Central and local officials have reformulated the goals of China's huji system and made significant changes in the day to day functioning of the institution but they have not chosen to abolish the system or weaken the importance of hukou status. Labour migration is now fundamentally different to migration under the planned economic model of the Maoist era that separated rural and urban and prevented migration between them. China is urbanising as in other developing regions of the world and is shaped by many of the same economic and social forces driving urbanisation. But in China, urbanisation is also influenced by the state. The huji institution acts as an intervening variable shaping the nature of migration, urbanisation and settlement. This intervening variable remains a key to understanding both China's changing migratory and settlement environment and the nature of the Chinese economic development model.

The rationales for the hukou regulations implemented in 1958 were to re-establish social stability, prevent uncontrolled urbanisation and to aid the development of the socialist planned economy. By 1978, the failure of the socialist planned economy and the accompanying social and political disillusionment with the disastrous Cultural Revolution (1966-1976) accumulated in a concerted effort by the Party-State to re- 
prioritise these and other goals. In hindsight, the most significant trend that emerged from 1978 was a growing consensus that the key task for China at that time was economic development and modernisation. ${ }^{6}$ The prioritising of economic development was further institutionalised as the Party-State gradually moved away from its ideological basis of legitimacy (democratic dictatorship of the proletariat) and economic success translated into not only significant domestic improvements in standards of living (first in rural areas and then predominantly in urban areas), but also to significant global praise and growing global economic power. ${ }^{7}$ Consequently, the rationales for ongoing macro-management of migration and settlement through the huji institution reprioritised and re-conceptualised 'development of the socialist planned economy' to simply 'economic development'. This now remains the primary goal of not only the huji institution but of also the ruling-party-elites who now measure social stability in terms of continuing exceptional growth and legitimize their ongoing elite-led autocracy through that growth.

Unlike urbanisation accompanying transition from pre-modern agrarian based economies to modern economic arrangements in other developing states, China's central and urban bureaucracies have attempted to macro-manage this urbanisation process by maintaining command economy powers through the huji institution to deny migrants permanent residency and access to welfare in urban areas. This creates a puzzle for researchers working from the baseline of the urbanisation trends of the developed world. In these cases, Taiwan and Japan included, rapid industrialisation and modernisation occurred in conjunction with rapid urbanisation and sustained economic development.

\footnotetext{
${ }^{6}$ Whilst Chinese academics and government officials have consistently promoted modernisation and economic development, 1978 saw a move from ideological socialist developmental rhetoric to pragmatic market-oriented rhetoric and the prioritising of economic development over all other goals (and in the service of those other goals). Economic development has become both the raison d'être of the Party-State and the means to accomplish other goals such as social stability.

${ }^{7}$ China is the second largest economy measured in GDP in international dollars (PPPs, UNData, 2007).
} 
In China, continued macro-management of economic development through the huji system provides an example of a very different development model. How that model makes use of the huji system and how the system has managed to endure has not been well explained in the existing literature on Chinese development.

The huji institution and associated hukou status is disliked by agricultural residents excluded from urban entitlements and non-agricultural residents tied to less-developed regions. It is quietly appreciated by urban elites in developed regions fearful of open competition and understood by all as the basis of one's political identity and social status. It is 'China's first credential'. ${ }^{8}$ Both central and municipal level government view it as an indispensable tool to manage the movement and settlement of Chinese citizens and as a way of allocating state services and resources to Chinese residents. Once the central government was solely responsible for the operation of the huji institution through quotas and central planning of the national labour force, of late, hukou transfer, population control and some huji policy-making has been devolved to urban bureaucracies at the local level. Accompanying this devolution has been a marketization of hukou status. This is represented by the introduction of temporary residency for unskilled rural labourers and the introduction of hukou transfer categories for those with skills, capital or assets. These themes will be explored in more depth in the case study sections and in the discussion of the dynamics of institutional change in China's huji system presented in the final chapter.

This research seeks to understand how government institutions are adapting to the changing conditions arising from the large scale internal migrations as a result of the growth of the market economy in China. The focus of the research is to demonstrate the

\footnotetext{
${ }^{8}$ Tian Bingxin 田炳新. 《中国第一证件: 中国户籍制度调查手稿》[China's First Credential: China's Huji System Research Manuscript]. 广州 [Guangzhou]: 广东人民出版社 [Guangdong People's Publishing House], 2003.
} 
nature of the relationship between economic development, the internal movement of migrants and changes in law, government policy and regulations regarding citizen's movement and residency. The institutional focus of the study is China's enduring huji institution. Overall, this research aims to provide greater understanding of the dynamic changes China's huji institution has experienced over the period 1978-2007 and to explain how and why these changes have occurred and how and why greater reform of the huji institution has not been forthcoming.

\section{Research Context and significance}

This thesis is significant for the following four reasons. Firstly, migration studies primarily study how political variables influence migration. More research is needed to understand better how migration influences institutional change (the agency and structure debate). This research aims to contribute to our knowledge of the relationship between the challenges increasing migration puts on government institutions and the changes these government institutions make to govern in this differing environment. The process of transition remains ongoing. Fundamental questions about the relationship between economic liberalisation and political liberalisation remain. China is far from democratic or pluralist and political reform and liberalisation remain the source of much critique. ${ }^{9}$ Dorothy Solinger argues transition to more liberalised market systems does not necessarily lead to political liberalisation and democratisation. ${ }^{10}$ It is however apparent that marketization has created new challenges for existing institutions in China. Furthermore, these institutions have experienced considerable reform. Understanding the nature of this reform and the relationship institutional change has with socio-economic change is an important part of understanding the broader politico-

\footnotetext{
${ }^{9}$ Yongnian Zheng, "Political Incrementalism: Political Lessons from China's 20 Years of Reform," Third World Quarterly 20, no. 6 (1999).

${ }^{10}$ Dorothy J. Solinger, Contesting Citizenship in Urban China: Peasant Migrants, the State, and the Logic of the Market (Berkley: University of California Press, 1999), ___, "The Creation of a New Underclass in China and Its Implications," (Irvine: Center for the Study of Democracy, University of California, 2005).
} 
economic changes in China over the last few decades. The creation of a labour market in China has led to the economic migration of tens of millions of nongmin to the cities and industrialised areas of China to gain relatively lucrative employment. Formal institutions in cities and those at the central government level now operate in an environment markedly different to that of 1978. At that time, the social, political and economic life of all shimin was heavily controlled by government institutions; nongmin were barred from the cities and without markets lacked the means to reside or work in urban areas. This effectively excluded them from residing and settling in urban areas. Local officials in particular have adapted the huji institution to promote economic growth and development at the local level. Whilst the traditional goals of the institution remain maintaining social order and stability, managing urbanisation and promoting economic growth, the question remains: how have China's governing institutions changed to meet the new challenges and imperatives brought about by a move to market economics? An analysis of the huji system can provide much needed insight into the greater political transition occurring in China since the policy of 'reform and opening' began. China's incremental transition provides a unique opportunity to study both the relationship between economic and political liberalisation as well as the effectiveness of incremental reform of China's political institutions and their adaptation to market conditions. This research does that through an analysis of the dynamic relationship between economic liberalisation, migrant agency and institutional adaptation of the hukou system.

Secondly, only relatively recently have scholars been granted greater access to government institutions for the purpose of social science research in China. At present, scholastic knowledge of the strategies, goals and methods the Chinese government employs to govern migrants remains understudied as does the institutional culture of the 
Chinese bureaucracy. This research aims to contribute to our understanding of how government institutions regulate and influence the movement of people in China. More specifically, it seeks to understand how and why the huji system has changed over the last two decades.

Thirdly, this study will contribute to theoretical debates in historical institutionalism by modelling the dynamics of institutional change in China's huji system (1978-2007). From this model it will be possible to extrapolate a more general theory of how and why institutions change and to comment on existing theories. This will primarily be of importance to studies of institutional change in China but it is also hoped that the model constructed may provide greater insight into institutional change in general.

Lastly, and more broadly, political science research in China attempts to understand the greater political, economic and social changes taking place in China since 'reform and opening'. This is often conceptualised as 'transition'. Much debate remains as to how China is changing, with scholars arguing 'transition' refers to a progressive move from a planned socialist state to a more liberal economic and political environment. Whilst many scholars have shown that China's politico-economic system increasingly resembles a capitalist market economy, debate continues over the political changes occurring. This research aims to contribute to this debate by analysing the institutional changes taking place due to the challenges brought about by increased migration driven by the reintroduction of markets to China. It aims to show the dynamics of institutional change in one of the most significant institutions of contemporary China, the huji system. This contributes to the overall debate regarding the development of political change in China. 


\section{Chapter Outline}

This research seeks to understand how the huji institution is adapting to the changing institutional environment and socio-economic conditions arising from the large scale rural to urban internal migrations and increasing commonality of agricultural hukou holders participating in non-agricultural employment as a result of the growth of the market economy in China. The focus is on explaining the adaptation of the primary functions of the huji institution over the period 1978 to 2007 and on explaining the dynamic relationship between hukou status, economic arrangements and socioeconomic migration and residency. At the heart of the study remains the objective to explain the dynamism between the variables: the growth of markets, the increase in migration and the institutional changes to the arrangements of the huji system. This research argues the huji institution has been maintained to meet institutional objectives but due to changing socio-economic conditions the formal regulations and their enforcement have changed significantly.

The first chapter overviews studies of the role migration plays in economic development. It looks to the economic changes in China over the transitional era for explanations of the rise in internal migration and the ongoing contribution of migrants to China's outstanding economic growth as well as studies that link this growth to political change. It presents economic theories of internal migration and arguments that utilise these theories in the Chinese context. It finds these studies fail to adequately consider the role the huji institution plays in labour mobility, economic migration and institutional change. From this three variables are identified-migration and residency, economic transition and the huji institution — and the core research questions are defined: What is the relationship between institutions and the socio-economic environment they operate within? How do institutions adapt to new institutional environments? How has 
the huji institution adapted to the transitional economy and increasing labour mobility in China? How do institutions change? It is argued current literature in this area has in general under-read the significance of hukou status to China's transitional economy and socio-political arrangements. This is followed by a discussion of the theoretical approach utilised, historical institutionalism, and an account of the methodology employed.

Chapter two begins the analysis by introducing the concept of China's transitional era (1978-2007), highlighting significant economic policy changes that have occurred and the role of internal migration over this period. This provides the needed background for a discussion of how these economic changes relate to growth in the internal migrant population, the division of agricultural/non-agricultural workers and changes to the way the huji institution now operates. The overall theme of the chapter is that China's economic reforms unleashed a dormant force within the Chinese economy, rural labourers (non-agricultural hukou status), and this force is in no small way responsible for the impressive economic growth of the reform era and China's ability to maintain a globally competitive advantage in many export sectors. Moreover, as this force was unleashed in non-agricultural sectors by Chinese residents of agricultural hukou status, this in many respects characterised, if not determined, the nature of that economic development (unskilled or low-skilled manufacturing, assemblage and construction) and significantly changed the socio-economic environment the huji institution operates in. The analysis then shifts to focus on the rise of internal migration in China. A short history of internal migration is followed by a closer look at the demographics of contemporary Chinese internal migration. This shows the overall trends of internal migration particularly focusing on the central role that nongmin (residents with agricultural hukou status) play in these migrations. A brief look at the well documented 
criticisms of the treatment and social status of these migrants is followed by the assertion that these migrants are exerting a form of agency on the existing institutional arrangements that historically bound them to the farm. The chapter concludes by restating the need to focus on institutional analysis to gain greater understanding of the nature of China's transitional era.

Chapter three moves on from constructing a picture of the changes in the institutional environment to focusing on the institutional arrangements of the huji system. It starts by looking carefully at the historical trajectory of the institution (pre-1911, 1911-1949, and 1949-1978), and shows that there is a high degree of historical legitimacy permitting the continuation of existing values, norms and rules. This is followed by a close look at the functions of China's huji institution and the ongoing efforts to macro and micro manage China's domestic migration. The next section shows the ongoing significance of the huji institution through an exploration of hukou as a determinant of life opportunity. This is followed by a summation of the most significant changes to the institution over the reform era and a re-formation of the original research question that seeks to explain how and why change has or has not occurred over the reform era.

Chapter four presents the first case study and builds the national level model of institutional change in China's huji system. New data sets are analysed to show changes in the institutional environment and these are linked to the changing application of the primary hukou functions. The link between China's economic transition and migratory patterns and changes in the way hukou regulations are formulated and applied is explored in depth over the period of study. The central argument of the chapter is that the huji institution in synchronicity with the changing socio-economic environment has experienced significant change in the application of existing goals - temporary non- 
hukou migration, the introduction of 'residency schemes' and the localisation of hukou management—but the goals themselves have not significantly changed: maintain social stability through institutional exclusion, prevent swamping of the urban areas by rural residents and promote economic development, growth and modernisation at the national level. Hukou is found to be significant in China's macro-economic management and overall national modernisation project, in rural to urban migration trends and rural/urban economic divergence and to China's deepening regional disparity. Moreover, this new socio-economic group with a unique institutional status is found to not only be limited to China's rural migrants. Details from a 2007 survey of hukou status throughout China show the problem of agricultural hukou holders living in urban areas with urban lives and non-agricultural employment is a significant problem for many existing residents swallowed by the tide of a rapidly urbanising China but failing to be granted 'urban status'. The chapter concludes by asserting the hierarchical and exclusionary nature of the huji institution remains a significant governing tool of the Party-State in contemporary China but that an emerging civic rights movement is increasingly pressuring local and central government for reforms based on the right to equality and freedom of movement and settlement.

Chapter five takes the analysis down to a lower level to show the regional variations in the changing application of the institution. Beijing and Shenzhen are each analysed and compared. This chapter shows that there is significant variation in the way hukou is applied to meet the age-old stability, prosperity and hierarchical order goals. The central theme of the chapter is that the application of these goals varies significantly depending on the environment the institution operates in. Shenzhen, an industrial zone created from farmland during the economic reform era, applies the huji institution to the above tasks in a manner significantly different to the way the Beijing bureaucracy does. Two 
findings are presented: that traditional forces dominate the functioning of the huji institution in Beijing far more than in Shenzhen; and secondly, that migration and economic reform (changing economic arrangements) are significantly correlated with the changing application of the primary hukou goals, i.e. the more significant the economic change and associated condition of 'agricultural hukou holders doing nonagricultural work,' the more significant the degree to which the application of the institutional goals have adapted.

Finally, chapter six presents the overall model of institutional change and re-evaluates the findings of the study in light of existing literature. The initial thesis is re-visited and general conclusions are made as to the process of institutional change in a transitional economy led by a corporatist Party-State. The core findings of the thesis is that the institutional objectives of the huji institution - maintain social stability, prevent urban overcrowding, promote economic modernisation and strengthen the governance of the Party-State - have been strengthened over the reform era through a process of adapting the way formal huji arrangements have been formulated and applied to meet the challenge of the rapidly changing socio-economic conditions. Secondly, these socioeconomic changes correlate with significant liberalisation of the formal institutional arrangements. Reform has prioritised economic development at the local level by liberalising huji management to allow development of skilled and unskilled labour markets. Increasing pressure from nongmin living and working in urban areas but excluded from hukou transfer continues to translate into modified formal institutional arrangements that attempt to meet the institutional objectives of local and central authorities and in some cases has led to deep reform of the institutional objectives themselves. A model of institutional change is put forward to explain these changes. The need for further research is discussed before the overall conclusions are re-stated. 


\section{Theoretical Framework and Methodology}

This research seeks to explain changes in China's huji system over the period 1978 to 2007 and develop a model of institutional change. The theoretical approach taken is historical institutionalism. This approach derives from the larger institutionalist school which is often referred to as new institutionalism. This chapter will first review theoretical models of economic migration that provide explanations for the growth of the migrant population, the focus of the overwhelming majority of scholarship in this field. Then a very brief history of the limitations and criticisms of 'old institutionalism' will be covered before discussing the theoretical concepts and three major approaches of new institutionalism. Rational choice institutionalism and sociological institutionalism will be mentioned briefly before historical institutionalism is looked at in more depth. Theories of institutional change will be conceptually outlined with particular focus on those theories that discuss change, path dependency and institutional 'stickiness'. Dorothy Solinger's use of 'agency and structure', as well as the variables identified in her influential 1999 book will be discussed. Then the institutional exclusion typology postulated by Fei-Ling Wang (2005) and the Lewis Transition theory (in conjunction with China's theory of circumvention) will be outlined and incorporated into the approach. Finally, the complete theoretical approach will be restated and the methodological approach outlined with particular reference to case studies, sampling and the limits of data collection when studying China's formal political institutions.

\subsection{Theoretical Models of economic Migration}

The marketization of China's once exclusively command economy is the impetus most scholars offer to explain growth in 'outside the plan' internal migration in China. ${ }^{11}$ The

\footnotetext{
${ }^{11}$ For example: Zai Liang and Michael J. White, "Market Transition, Government Policies, and Interprovincial Migration in China: 1983-1988," Economic Development and Cultural Change 45, no. 2 (1997).
} 
central argument views markets as drivers of migration and can be traced back to Ravenstein's analysis of the British Census of 1881. Ravenstein argued that there is an 'economic motive' in the form of a desire inherent in most people to 'better themselves in material respects ${ }^{12}$ and this assertion remains the basic assumption of economic theories of migration. The most commonly used theoretical models of the economics of Chinese internal migration are the neoclassical, the push-pull models developed from Everett Lee's 1966 work and the Lewis Transition models.

At the macro level, neoclassical economic theory argues that, “...international migration, like its internal counterpart, is caused by geographic differences in the supply of and demand for labor." ${ }^{\prime 13}$ Labour moves out of areas of oversupply and poor wages or work opportunities to areas where there is demand, higher wages and more opportunity. At the microeconomic level, neoclassical economic models of migration employ the theory of individual choice arguing that, “...individual rational actors decide to migrate because a cost-benefit calculation leads them to expect a positive net return, usually monetary, from movement... In theory, a potential migrant goes to where the expected net returns to migration are greatest..." ${ }^{, 14}$ George J. Borjas, a proponent of this approach, summarises this with striking similarity to Ravenstein, “...individual migration behaviour is guided by the search for better economic opportunities..."15

Everett S. Lee’s 1966 paper, ‘A Theory of Migration', introduces a 'general schema' for internal and international migration studies highlighting four factors that influence migration: 'factors associated with the area of origin, factors associated with the area of

\footnotetext{
${ }^{12}$ E.G. Ravenstein (1885 and 1889) cited in: Michael P. Todaro, Internal Migration in Developing Countries: A Review of Theory, Evidence, Methodology and Research Priorities (Geneva: International Labour Organisation, 1976).

${ }^{13}$ Douglas S. Massey et al., "Theories of International Migration: A Review and Appraisal," Population and Development Review 19, no. 3 (1993). p.433.

${ }^{14}$ Ibid. pp.434-435.

${ }^{15}$ George J. Borjas, "Economic Theory and International Migration," International Migration Review 23, no. 3 (1989). p.457.
} 
destination, intervening obstacles, and personal factors' ${ }^{16}$ Both origin and destination are said to hold both positive and negative forces repelling and attracting potential migrants from and to the destination and origin areas. These forces are what Lee describes as 'push' and 'pull' factors. Theoretically, the propensity to migrate is characterised by the overall 'push' and 'pull' equation and the addition of 'intervening obstacles' (such as distance to travel, racism or immigration quotas) and 'personal factors'. Differing from the neoclassical models, Lee argues that, "The decision to migrate ... is never completely rational, and for some persons the rational component is much less than the irrational." ${ }^{17}$ Lee's work, for most, has been adapted to an economic focus on the demand for labour in certain areas as a 'pull' for migrants, whilst relative deprivation of the economic dimension and overpopulation (oversupply) in other areas are described as push factors. ${ }^{18}$

The 'Lewis Transition' or Lewis-Fei-Ranis (LFR) model focuses on the role of the agricultural sector, 'surplus labour' and internal migration in developing/'third world' countries. ${ }^{19}$ It was "the received 'general' theory of the development process in 'labour surplus' Third World nations during most of the late 1950s and 1960s."20 The LFR model dichotomises the economy of developing countries into two sectors: a traditional rural subsistence sector (low productivity; 'surplus labour'), and a high productivity modern urban industrial sector. Development entails transference of 'surplus labour' from the low productivity subsistence sector to the high productivity modern urban industrial sector through growth of employment in the modern sector. The LFR model

\footnotetext{
${ }^{16}$ Everett S. Lee, "A Theory of Migration," Demography 3, no. 1 (1966). p.50.

${ }^{17}$ Ibid. p.51.

${ }^{18}$ James F. Hollifield, "The Politics of International Migration: How Can We 'Bring the State Back in'?," in Migration Theory: Talking across Disciplines, ed. Caroline B. Brettell and James F. Hollifield (New York: Rouledge, 2000).

${ }^{19}$ Gustav Ranis and John C. H. Fei, "A Theory of Economic Development," The American Economic Review 51, no. 4 (1961).

${ }^{20}$ Todaro, Internal Migration in Developing Countries: A Review of Theory, Evidence, Methodology and Research Priorities. p.21.
} 
postulates that the speed of transfer is dependent on the rate of capital investment in the modern sector and that urban wages will remain constant until the 'surplus labour' pool is used up. ${ }^{21}$ The process of structural transformation is assumed to be dependent on the transference of labour (migration) to the modern sector. Moreover, “... modern sector growth and employment expansion is assumed to continue until all 'surplus' rural labour is absorbed in the urban industrial sector. Thereafter the labour supply curve becomes positively sloped and both urban wages and employment will continue to grow. The structural transformation of the economy will have taken place with the balance of economic activity shifting from rural agriculture to urban industry.",22

\subsection{Economic Explanations for the Growth of the Migrant Population in China}

The Lewis Transition model highlights two important points for internal migration in developing economies that are particularly applicable to China: firstly, the importance of the structural and economic differences between the rural and urban sectors; and secondly, the importance of labour transfer to the development process. The Lewis Transition model predicts that migration in China will continue to flow from the rural sector to the urban sector in response to higher wages and that this is part of China's developmental transition. Push-pull models and neoclassical theory predicts labour migration will move towards wealthy high employment areas away from poorly developed rural labour markets. These theories are premised on the assumption of free markets and explain the growth in the migrant population in the following general ways: firstly, the breakdown of collectivisation, the introduction of the 'household responsibility system' (HRS), ${ }^{23}$ and the modernisation of agriculture that led to excess rural labourers seeking employment; secondly, the creation of private enterprise and

\footnotetext{
${ }^{21} \mathrm{Ibid}$.

${ }^{22}$ Ibid. p.23.

23 家庭联产承包责任制
} 
markets that allowed rural migrants to survive and participate in urban economies and provided the economic incentive to try to improve their economic livelihood; and finally, the incremental 'opening' of specific areas of China to market regulations, foreign direct investment (FDI) and joint enterprises that led to a widening of regional and socioeconomic disparity.

Firstly, migration is said to have increased due to the breakdown of collectivisation, the introduction of the HRS and the modernisation of agriculture that released many nongmin from the land creating a huge surplus labour pool. ${ }^{24}$ The policy that set-off the modernization of the agricultural sector and led to the breakdown of the commune system was not originally intended to return the right of rural people to farm the family plot; in fact, the Third Plenum of the 11th Central Committee of the Communist Party of China (Dec, 1978) specifically banned this. ${ }^{25}$ However, reducing taxes, stabilising compulsory procurement quotas, raising prices, increasing state investment in agriculture and granting greater autonomy to collectives, “...set off a complex series of interactions between peasants and government leaders that eventually led to the 'rural responsibility system' and the widespread adoption of family farming. ${ }^{26}$ Rural people began dividing land up to individual households and an unstoppable trend-supported by some influential politicians such as Zhao Ziyang, then head of Sichuan provincetowards the now standardised household responsibility system (HRS) began.

The uptake of the HRS and a return to a system more closely resembling the one prior to 1955 was swift with $0 \%$ uptake in $1978,1 \%$ in $1979,14 \%$ in $1980,45 \%$ in 1981 ,

\footnotetext{
${ }^{24}$ For a good historical summary of this argument see: Hein Mallee, "Migration, Hukou and Resistance in Reform China," in Chinese Society: Change, Conflict and Resistance, ed. Elizabeth J. Perry and Mark Seldon (New York: RoutledgeCurzon, 2000).

${ }^{25}$ Barry J. Naughton, Growing out of the Plan: Chinese Economic Reform, 1978-1993 (Cambridge: Cambridge University Press, 1995).

${ }^{26}$ Ibid. p.139 Author's Italics.
} 
$80 \%$ in $1982,98 \%$ in 1993 and $99 \%$ from 1984 onwards. ${ }^{27}$ As the change to the HRS intensified the government retrospectively gave formal blessing to the system. It is this system which is largely attributed with providing the impetus for greater efficiency, productivity and the modernization of agriculture that led to a requirement for less agricultural labourers and consequently high unemployment in rural areas. The creation of this 'excess' labour pool is commonly used as explanation for the rise in the number of nongmin migrating to the cities in search of work, often retaining their family plots of land, working dual occupations and living 'dual lives'. ${ }^{28}$ Moreover, the “...tremendous abundance of labour in rural areas is one of the most perplexing issues currently facing policy-makers in the People's Republic of China. Central and municipal authorities fear that large-scale labour movement out of rural China will have politically and socially destabilising effects on the cities and towns to which workers migrate.,"29

The breakdown of collectivisation in rural areas had a significant impact on the number of rural people migrating to urban areas as it freed them from the land and unleashed the economic advantages of China's pent up labour market conditions. This has allowed the Chinese economy to again enjoy a considerable global competitive advantage. The migratory conditions in China over the reform era support the assertions of the neoclassical and push-pull models of migration (the economic motivation to migrate) and the Lewis Transition. The creation of 'excess' rural labour and increased rural to urban migration supports the Lewis Transition's assertion that moving from a premodern economy (primarily focused on agriculture and primarily made up of a rural population) to modern economic arrangements requires the modernization of agriculture

\footnotetext{
${ }^{27}$ Justin Yifu Lin, "Rural Reforms and Agricultural Growth in China," The American Economic Review 82, no. 1 (1992). p.38.

${ }^{28}$ Xiaobu Hu, Gabe T. Wang, and Yimin Zou, "Political Economy of the Floating Chinese Population," Journal of Contemporary Asia 32, no. 4 (2002).

${ }^{29}$ Denise Hare, "'Push' Versus 'Pull' Factors in Migration Outflows and Returns: Determinants of Migration Status and Spell Duration among China's Rural Population," The Journal of Development Studies 35, no. 3 (1999). p.45.
} 
and the transfer of labour to urban areas to take part in the modern, industrialising economy. This model also predicts that this transition will continue until 'the balance of economic activity has shifted to the urban areas,' thus predicting that transition in China is far from complete and that the large rural population will continue to be a source of rural-to-urban migration for some time to come.

Secondly, markets gave migrants the ability to survive in the cities where once they could not and provided migrants the economic incentive to try to improve their economic livelihood by seeking work in the market economy of predominantly urban areas. $^{30}$ The reintroduction of markets is seen as weakening the effectiveness of China's population control mechanism, the huji institution, as migrants can now survive 'outside the plan' in the market economy. ${ }^{31} H u k o u$ had been strictly enforced in the decades prior to reform and was successful to a large degree because of the improbability of surviving 'outside the plan' in Maoist China. This argument essentially relies on the notion that prior to the reform period politico-economic arrangements were not conducive for rural-to-urban migrations without government sanction and transfer of hukou status. Simply put, without a market economy enabling people to find employment or be entrepreneurial, to find food and shelter or to be allocated essential services such as healthcare and education, it remained virtually impossible to survive 'outside the plan'. Markets provided for these demands, creating an environment conducive to migration, with or without state sanction.

Moreover, markets not only allowed internal migration to take place, they also encouraged and in fact required it to do so. The growth of the private economy provided jobs for rural labourers compelling the state sector to also take on contract workers in

${ }^{30}$ Solinger, Contesting Citizenship in Urban China: Peasant Migrants, the State, and the Logic of the Market.

${ }^{31}$ Mallee, "Migration, Hukou and Resistance in Reform China." 
order to remain competitive with private industry. At this time the urban 'iron rice bowl', or what Solinger describes as the 'urban rationing regime' also began to be dismantled. ${ }^{32}$ As the private economy grew the demand for labour grew and migration became not only possible but desirable to both migrants and businesses requiring labour at competitive market prices. As migration increased the economy grew and as the economy grew migration was further encouraged. Both macro and micro neoclassical models of migration express the empirical situation in China as do the push-pull models which predict migration will occur in part due to economic disparity. That internal migration in China, particularly rural-to-urban migration, is positively correlated with the growth in markets in urban areas remains a central theme of nearly all studies of the floating population, as these developing urban areas provide the pull needed to compel people to leave their homes.

This is also consistent with the work of Castles and Miller who argue markets 'give rise' to migrations: "Migrations are not isolated phenomenon: movements of commodities and capital almost always give rise to movements of people..." ${ }^{, 3}$ Previously, China's planned economy and strict implementation of the huji institution prevented nearly all spontaneous migrations. Commodity and capital allocation by central government did link various regions of China, including the urban and rural worlds, but the absence of markets and strict control of the allocation of commodities, capital and labour, prevented their movements 'giving rise' to migrations. After the re-introduction of markets, migrations remained restricted (especially in settlement) but markets themselves provided a means of survival and relative prosperity. This meant that China's migration patterns have again begun to resemble international and internal

\footnotetext{
${ }^{32}$ Meaning, lifetime employment, employment allocation, rationing, state housing, universal urban healthcare and other public services for urban people were phased out to decrease the budgetary burdens of the central government and urban bureaucracies.

${ }^{33}$ Stephen Castles and Mark J. Miller, The Age of Migration (New York: Guilford Press, 2003). p.4.
} 
migration in other states; movements of commodities and capital now 'give rise' to movements of Chinese citizens. As markets grow and more and more commodities and capital flow over China, it is expected that movements of people will also increasewith or without further huji reform.

Thirdly and finally, due to the incremental nature of the reforms, market opportunities were targeted to very specific areas of China. This incremental 'opening' of specific areas of China to market forces, FDI and joint enterprises has led to a widening of regional and socioeconomic disparity, and this has created increasing economic motivation for those in underdeveloped regions or underdeveloped 'classes' to migrate and try to improve their life opportunities. Economic transition in China is by no means regionally or socio-economically balanced. C. Cindy Fan's 1995 study of the 'evolution of Chinese regional policy' closely examines China's economic 'opening' to global markets and FDI, as well as their incremental adoption of market economics and experimental use of tax concessions and favourable economic policies in certain regions. The Chinese Government actively encouraged the regionally targeted transition of the Chinese economy to a market economy. ${ }^{34}$

Studies have confirmed the importance of this regional differentiation in contributing to the rise of the nongmingong population finding that labour migrations are significantly correlated with relative incomes. ${ }^{35}$ The common Chinese saying 'the peacock flies to the south and east ${ }^{36}$ is supported by studies showing the regional increase in the size of the floating population as greatest in Shanghai, Guangdong and Zhejiang: "Despite the

\footnotetext{
${ }^{34}$ C. Cindy Fan, "Of Belts and Ladders: State Policy and Uneven Regional Development in Post-Mao China," Annals of the Association of American Geographers 85, no. 3 (1995).

35 Justin Y Lin, Gewei Wang, and Yaohui Zhao, "Regional Inequality and Labor Transfers in China," Economic Development and Cultural Change 52, no. 3 (2004).

36 孔雀东南飞: referring to a perceived tendency for migrants to seek work in coastal and southern regions.
} 
Chinese government's policy of encouraging the development of western regions of the country, China's coastal regions, and especially the province of Guangdong, experienced the largest increase in the size of the floating population." ${ }^{37}$ Calculations of GDP per capita by province also suggest there is a positive correlation between the regional density of the floating population and the regional distribution of wealth. ${ }^{38}$ Studies of China's integration into the global economy and the geopolitical dispersion of foreign capital to the coastal and urban areas of China find a positive correlation between FDI and the concentration of rural migrants. ${ }^{39}$

Confounding studies of regional inequity is rural-urban inequity. One study of rural urban inequality in Jiangsu and Sichuan found that, “...rural-urban income differentials constitute a large share of total inequality, and the widening sectoral gaps in recent years have caused the rising inequality in China. ...the rise in sectoral disparity has resulted from increased urban subsidies, investments and credits ... This urban-biased policy mix is ... detrimental to China's future growth because the sector-biased income transfers and expenditures on health, housing and education not only distort economic incentives of workers in the sectors, but will also affect the human capital attainments of their children, which may further widen the rural-urban income gap." ${ }^{40}$ A more recent study shows the Lewis Transition in effect but also notes the continuing significance of the huji institution: “...migrant labor shortage in China not only reflects a declining wage gap between what peasants receive and what migrants can earn in the cities, but also the institutional legacies of the planning era such as the hukou (household registration) system which discriminates against migrants vis-a-vis urban residents in

\footnotetext{
${ }^{37}$ Zai Liang and Zhongdong Ma, "China's Floating Population: New Evidence from the 2000 Census," Population and Development Review 30, no. 3 (2004), p.484.

${ }^{38}$ Ibid. see Appendix p.485.

${ }^{39}$ Zai Liang, "Foreign Investment, Economic Growth, and Temporary Migration: The Case of Shenzhen Special Economic Zone, China," Development and Society 28, no. 1 (1999).

${ }^{40}$ Dennis Tao Yang, "Urban-Biased Policies and Rising Income Inequality in China," The American Economic Review 89, no. 2 (1999), pp.309-310.
} 
terms of access to social insurance and other social services." ${ }^{\text {41 }}$ These studies confirm that both regional and socioeconomic inequity continue to be important forces for migration in China and suggest the huji system is an important variable in the continuation of that socioeconomic disparity.

'Push' and 'pull' economic forces, exasperated by uneven modernization and the reintroduction of individual capital gain, give the impetus for migration to urban and coastal regions. The result of uneven economic development and extreme socioeconomic disparity follows the classical economic rationale that people move to better their economic opportunities for themselves and/or their children. Denise Hare's 1999 study of 'push' and 'pull' factors in migration outflows and returns also confirms this. ${ }^{42}$ China's phenomenal but regionally and socio-economically uneven economic growth during this period provides a compelling explanation, based on the Lewis Transition and an analysis of regional economic differences, for the continued growth of the rural migrant population in urban centres. These economic models of migration look to economic transition and marketization to explain the increase in internal migration and show that newly created markets, especially the labour market, have created the impetus and provided the necessary conditions for people to migrate to areas of economic opportunity. These studies however fail to take into account the important role the huji institution plays in maintaining the continuing socio-economic disparity and regulating settlement in urban areas.

\footnotetext{
${ }^{41}$ Sijun Shao et al., "Migrants as Homo Economicus: Explaining the Emerging Phenomenon of a Shortage of Migrant Labor in China's Coastal Provinces," China Information 27, no. 7 (2007), p.27.

${ }^{42}$ Hare, "'Push' Versus 'Pull' Factors in Migration Outflows and Returns: Determinants of Migration Status and Spell Duration among China's Rural Population."
} 


\subsection{The Limitations of Economic Explanations}

Most scholars studying China's age of migration have used the transition of China's economy and the creation of markets to explain the growth of internal migration, particularly rural-to-urban migration. These studies show that regional disparity and socioeconomic disparity are important drivers of migration and provide evidence of the importance of marketization to China's increasing patterns of urbanisation and internal migration. Similarly, they find that the transfer of labour from premodern agriculturally based conditions to modern industrialised markets continues to occur and is predicted to continue for some time due to China's extremely large rural population. Finally, they contend that China's patterns of internal migration are similar to international patterns of migration characterised by large quantities of 'illegal' migration and employment, kinship networks, self-organising and patterns of chain migration. The three broad economic theories covered here go a long way to explaining the growth in urbanisation and internal migration in China. However, these explanations are limited as they generally fail to adequately incorporate the role of formal institutions in the analysis and this is a major deficit in the application of economic models and in their focus of enquiry. Other studies have broadened the enquiry and identified important interactions between the state, migrants and the market.

Fan's 1995 study of China's regional development plan shows the crucial role of the state in creating targeted economic growth and transition to market economics. Dorothy Solinger, like Hein Mallee, ${ }^{43}$ emphasises the role of migrant agency in her 1999 work, Contesting Citizenship in Urban China, and focuses on the role of the state and market in creating the migration phenomenon as well as their role in changing institutional and economic policy. Solinger argues that, “...migrants in the cities themselves - along with

\footnotetext{
${ }^{43}$ Mallee, "Migration, Hukou and Resistance in Reform China."
} 
markets-had a major influence on the unfolding of policy, on the style of administration, and the behavior of the managers..." identifying a 'reciprocally interactive relationship' and a 'mutually transforming relationship' of migrants, markets and the state. ${ }^{44}$ Similarly, the work of Fei-ling Wang and Lu Yilong identify the importance of the huji institution to China's migratory and settlement patterns as well as its politico-economic implications. ${ }^{45}$

These studies have directed this project to incorporate economic analysis, to take seriously the growing pressures migrants are bringing to bear on the current institutions in urban China and to look to the dynamic interaction between these variables and the existing institutions as a way of identifying and explaining the patterns of institutional adaptation and stability over the reform era. For this reason an institutionalist approach is well suited to this study and in fact necessary to gain a more complex understanding of the importance of the changing institutional environment to the process of institutional adaptation. This thesis does not refute the claims that changes in China's economic development model are correlated with increased migration. However, it also looks further arguing that migration and the accompanying agency is not only 'changing the face of urban China' but also creating dynamic changes in China's enduring huji institution. This approach derives from the work of many scholars who have argued that when studying transitional economies it is necessary to apply a framework which has the ability to measure important aspects of the institutional arrangements that purely economic models miss. "In transitional economies, such as those in Russia and China, that are negotiating the difficult match between plan and market, investigations of

\footnotetext{
${ }^{44}$ Solinger, Contesting Citizenship in Urban China: Peasant Migrants, the State, and the Logic of the Market, pp.278-279.

${ }^{45}$ Fei-Ling Wang, Organizing through Division and Exclusion: China's Hukou System (Stanford University Press, 2005), Lu Yilong 陆益龙. 《户籍制度：控制与社会差别》[The Huji System: Control and Social Disparity], 社会图像丛书 [Social Images Series]. 北京 [Beijing]:商务印书馆 [The Commercial Press], 2003.
} 
institutions are especially revealing. ${ }^{" 46}$ The next section outlines how this study utilises and situates the institutionalist approach with the current literature on China and institutionalism.

\subsection{Theoretical Framework}

The study of power and institutions has been the key focus of political studies throughout the development of the discipline. ${ }^{47}$ Whilst power has always remained of central concern, institutional analysis became widely unpopular in the post-war years due to criticisms of it being unscientific, subject to selection bias and overly descriptive. These criticisms were directed at the work of Marx and Weber but also to the normative stance of studies postulating 'ideal government arrangements'. On the back of such criticism, the reductionist theoretical paradigms and methodologies of the behaviourist school that imitated scientific methodologies in the hard sciences began to dominate political studies in the 60 s and 70 s. Then, starting in the early 1980 s and largely due to the failures of the behaviourist school to develop non-falsifiable predictive models, institutional analysis began again to be seen as one of the key pillars of the study of the political world and a growing literature utilising this approach was again identified and acknowledged.

New institutionalism argues that institutions matter, particularly the institutions of the polity and economy, because they shape the behaviour of actors. The most common definition of an institution is 'rules'. ${ }^{48}$ Hall and Taylor (1996) define institutions as, “... the formal or informal procedures, routines, norms and conventions embedded in the

\footnotetext{
${ }^{46}$ C. Cindy Fan, "The Elite, the Natives, and the Outsiders: Migration and Labor Market Segmentation in Urban China," Annals of the Association of American Geographers 92, no. 1 (2002), p.119.

${ }^{47}$ Stephen Bell, "Institutionalism," in Government, Politics, Power and Policy in Australia, ed. John Summers, Dennis Woodward, and Andrew Parkin (NSW Australia: Pearson Education Australia, 2002).

${ }^{48}$ Sven Steinmo, "Historical Institutionalism," (Colorado University, 2007). http://sobek.colorado.edu/ steinmo/HistoricalInstitutionalism.pdf.
} 
organizational structure of the polity or political economy." ${ }^{\text {49 }}$ Formal institutions refer to the formal rules, regulations, guidelines and laws of political and economic systems whereas informal institutions refer to the norms, ideas, values and beliefs that guide actors' choices in an institutional setting. At its core, all institutional analysis-whether formal or informal, rational, sociological or historical - argues that institutions matter because they shape the behaviour of actors within the institutional framework. Hall and Taylor (1996) argue that new institutionalism is characterised by the following general points: it conceptualises the relationship between institutions and individual behaviour in relatively broad terms focusing on what institutions do and why they persist over time; it emphasizes the asymmetries of power associated with the operation and development of institutions; it views institutions in terms of path dependence and unintended consequence; and finally, it is concerned with incorporating other kinds of factors, such as ideas, into the institutional analysis of political outcomes. ${ }^{50}$ The three main theoretical approaches of new institutionalism, whilst generally sharing these commonalities, have both ontological and methodological differences which make them mutually exclusive as theoretical approaches. These three distinctive approaches are rational choice institutionalism, sociological institutionalism and historical institutionalism. $^{51}$

Rational choice institutionalism employs a 'characteristic set of behaviourist assumptions', namely, that actors have a fixed set of preferences, behave instrumentally so as to maximise these preferences and do so through extensive calculation of the most strategic approach. ${ }^{52}$ Rational choice institutionalism postulates that institutional actors are driven by rational self-maximising choices that they exercise within the institutional

\footnotetext{
${ }^{49}$ P. A. Hall and R. C. R. Taylor, "Political Science and the Three New Institutionalisms," Political Studies 44, no. 4 (1996), p.6.

${ }^{50}$ Ibid.

${ }^{51}$ Ibid.

${ }^{52}$ Ibid.
} 
setting. Moreover, these assumptions lead rational choice institutionalists to view politics as a series of collective action dilemmas (when individual self interest leads to suboptimal collective outcomes) such as that exposed in the classic 'prisoner's dilemma'. Rational choice institutionalism is distinct from sociological institutionalism.

Sociological institutionalism developed independently of rational choice institutionalism through research in the sociology discipline. However, this theoretical approach has also come to be of interest to political science. Sociological institutionalism incorporates the concept of 'culturally specific practices', which include not only the formal rules, procedures or norms of institutions, but also the "...symbol systems, cognitive scripts, and moral templates that provide the 'frames of meaning' guiding human action." 53 Thus, sociological institutionalism not only incorporates 'cultural practices' into the institutional analysis but also breaks down the divide between institutions and culture, arguing that the two shape each other. Culture is seen as the network of routines, symbols or scripts providing the templates for behaviour. Sociological institutionalism therefore rejects the notion that people are purely selfmaximising rational beings with perfect strategic information, rather postulating that behaviour is affected by institutions due to the cultural learning of the actors. Whilst historical institutionalism has been conceptualised as a combination of both sociological and rational choice assumptions, it is also a distinct and ontologically separate approach under the new institutionalist banner. ${ }^{54}$

Historical institutionalism, the approach taken in this research, is part of the new institutionalist school because it also seeks to explain how institutions shape the behaviour of actors. It differs, however, due to the added emphasis on time, path

\footnotetext{
${ }^{53}$ Ibid, p.14.

${ }^{54}$ Colin Hay and Daniel Wincott, "Structure, Agency and Historical Institutionalism," Political Studies XLVI (1998).
} 
dependence, change and ideas. ${ }^{55}$ So, whilst historical institutionalism is also focused on analysing and explaining how institutions shape behaviour, and can and does incorporate both rational choice and sociological concepts of actor behaviour, the distinguishing feature of this approach is the focus on institutional change over time. Historical institutionalism takes time seriously and argues that political events happen within a historical context that has direct consequence on decisions or events. Because behaviour, attitudes and strategic choices take place within particular social, political, economic and even cultural contexts it is argued that variables should be situated within these contexts. ${ }^{56}$ Historical institutionalism is a theoretical approach that does not seek to predict, but rather seeks to explain. "Prediction and the related conception of science imply a linear analysis of variables that can be distinguished from one another and which react to one another in predictable ways... For many social scientists, such analysis denies the realities of the world in which we live." ${ }^{, 57}$ Old institutionalism, such as the theories of Marx, have been highly criticised for being overly deterministic. Marx postulated a linear progression of history, arguing that there is a universal development of the economy and the polity. New institutionalism rejects such a view, rather arguing that institutions change but that change is in no way predictable and does not follow a set developmental progression. Historical institutionalist studies seek to explore and explain questions such as: why has an institutional arrangement remained stable? And, why has an institutional arrangement changed? This approach does not assume that there is a universal progression of polity and economy; rather it argues that change resides in the interaction of historical institutional arrangements (including learned strategic behaviour) and in the presence of a variety of changing variables.

\footnotetext{
55 Ibid.

${ }^{56}$ Steinmo, "Historical Institutionalism."

${ }^{57}$ Ibid, p. 16
} 
Historical institutionalism has put forward four theories of institutional stability (not changing over time/equilibrium). Firstly, historical institutionalist scholars have argued that any institution is set within a larger set of institutions and therefore changing rules in one institutional setting will be met with resistance from the broader set of institutional arrangements. Secondly, it is argued that human beings form expectations around a set of rules and due to the unpredictable nature of changing those rules they often remain resistant to such change. Thirdly, change is costly as actors have invested heavily in learning the rules and therefore there is resistance to change. Finally, as institutions shape behaviour, institutional rules can shape preferences over time. ${ }^{58}$ Institutional stability or equilibrium is often conceptualised as 'institutional stickiness' when institutional arrangements are slow to adapt to a changed environment. Furthermore, historical institutionalists argue that not only are institutions prone to institutional 'stickiness' and often remain stable over time, but also that the development or evolution of institutions remains 'path dependent'. Path dependency, “...rejects the traditional postulate that the same operative forces will generate the same results everywhere in favor of the view that the effect of such forces will be mediated by the contextual features of a given situation often inherited from the past." ${ }^{, 59}$ Institutional arrangements inherited from the past are significant because they push institutional development along a set of paths and other variables that effect the institutional arrangement are in fact themselves mediated by previous and current institutional arrangements and learned actor behaviour. Unintended consequences of previous institutional arrangements occur when institutional arrangements designed under historical circumstances then mediate and interact with a changed institutional environment. Path dependency is a useful conceptual tool for explaining the limits and likely paths of institutional change and is generally used to show the reasons for an

\footnotetext{
58 Ibid.

${ }^{59}$ Hall and Taylor, "Political Science and the Three New Institutionalisms." p.9.
} 
institution remaining stable over a period of time even when the institutional environment has changed, sometimes significantly.

Whilst historical institutionalism is focused on explaining how and why institutions change or remain stable, most work has been done theorising how institutions remain stable and theories of change remain few and understudied. Theories of change include the idea that institutions remain stable (at equilibrium) until they are faced with an exogenous shock. This idea has been criticised as limiting because at times institutions change without any recognizable exogenous shock. ${ }^{60}$ Endogenous institutional change theories (those that account for change without relying on the presence of an external shock variable) remain few. Streeck and Thelen (2005) provide a thorough review of studies focusing on the question of change, delineate informal and formal institutions and put forward the notions of 'gaps' between the formal institutional arrangements and the 'enactment' of institutions. From their review of the literature and other chapters in the same book they suggest there are five broad modes of gradual but transformative change. These are displacement, layering, drift, conversion and exhaustion. These modes of gradual transformation are used to frame the question of liberalization in advanced political economies. This thesis takes seriously their observation that there “... is a tendency in the literature to understate the extent of change, or alternatively to code all observable changes as minor adaptive adjustments to altered circumstances in the service of continuous reproduction of existing systems. ${ }^{\prime 61}$

How, why and to what degree institutions change, remains the most exciting area of historical institutionalist research. This thesis seeks to explain institutional change

\footnotetext{
${ }^{60}$ Steinmo, "Historical Institutionalism."

${ }^{61}$ Wolfgang Streeck and Kathleen Thelen, "Introduction: Institutional Change in Advanced Political Economies," in Beyond Continuity: Institutional Change in Advanced Political Economies, ed. Wolfgang Streeck and Kathleen Thelen (New York: Oxford University Press, 2005), p.3.
} 
within China's huji system and construct a model of institutional change from these observations. The focus is on both how and why there is overall stability and continuity and on how and why certain aspects of the formal institutional arrangements have changed. Hay and Wincott (1998) postulate that it is the relationship between 'structure and agency' that is crucial to understanding how and why institutions change over time. This thesis also utilises a 'structure and agency' approach modelled on Dorothy Solinger's influential 1999 book, Contesting Citizenship in Urban China: Peasant Migrants, the State, and the Logic of the Market. Solinger outlines three institutions in China: the exclusive migration control hukou system; a set of urban bureaucracies; and, a regime of planning and rationing that favoured the privileged urban group. Migrant 'agency' is then looked at as Solinger shows how markets have made it possible for 'peasants' to survive in China's once protected urban areas and highlights how this agency is affecting the running of the three institutions previously mentioned, which were designed to keep peasants out of the cities. ${ }^{62}$ Solinger concludes that:

"... [T]hree older institutions_policies promulgated by officialdom, the
cumbersome and well-entrenched bureaucracy, and the urban rationing
regime-that had worked together to shore up citizenship, remained in the
reform era to contort the substance of that concept. And yet the migrants in the
cities themselves_along with markets—had a major influence on the unfolding
of policy, on the style of administration, and on the behavior of the managers,
even as their presence and praxis contributed to refashioning the modes of
distribution in the city. This reciprocally interactive relationship was apparent
especially in the ways migrant workers created their own labor markets and in
how some of them used markets to scrape together services central to survival
in the cities, in the process of depriving the state of its old ability to dispose of
the work force and to distribute to the city populace exactly as it chose..03

Solinger argues that through a process of interaction between both structure (top-down institutional changes) and agency (markets and economic migration) there have been changes to the way the hukou system operates, as well as the operation of the urban bureaucracy and urban rationing regime. However, Solinger's focus is primarily on the

\footnotetext{
${ }^{62}$ Solinger, Contesting Citizenship in Urban China: Peasant Migrants, the State, and the Logic of the Market.

${ }^{63}$ Ibid, pp. 278-279
} 
citizenship rights of the rural migrants. Her study clearly shows that, whilst rural migrants are 'contesting citizenship' and there have been some institutional changes, rural migrants are yet to be accorded the same citizenship rights as registered city residents. ${ }^{64}$ Whilst this second conclusion is of grave significance to the present and future social harmony of China, it is the first of Solinger's conclusions, that institutional change has occurred, that is of direct relevance to this study.

This research seeks to further our understanding of the inter-dependent relationship between markets, migrants and the formal state institution - the huji system - in China, focusing on the question, 'how and why has the huji system changed over the period 1978 to 2007?' Solinger's study shows the significance of two new forces in contemporary China: markets and migrants. ${ }^{65}$ She argues that whilst before the $1980 \mathrm{~s}$ markets and migrants did exist, they were minimal in the strictly controlled Maoist state. Post-1980, however, both markets and migrants have grown extremely fast, allowing certain economic and migratory freedoms for both rural and urban people, ${ }^{66}$ and creating challenges to the institutional arrangements of the huji system. The growth of markets has created an environment more conducive to migration and the agency of migrants has played an important role bringing about institutional change in China's huji system. This thesis seeks to add to the debate over institutional development/change by seeking to explain the inter-dependent relationship between strategic action on the part of economic migrants (agency) and the institutional arrangements of the huji system (structure). To aid the modelling of the temporal contextual interrelations between these variables, the type of institutional change that

\footnotetext{
64 Ibid.

65 Ibid.

${ }^{66}$ Before China's markets re-emerged 'peasant migrants' could not survive in the cities because they were excluded from the allocation of state resources, what Solinger calls the 'urban rationing regime', and lacked markets to buy necessities and make a living. Now, whilst still for most denied state assistance, 'peasant migrants' can now at least maintain subsistence levels in the market economy.
} 
China's huji system has been going through over the period 1978 to 2007 is conceptualised as the adaptation of a geopolitical and command economy model of institutional exclusion to the demands of a market economy through the addition of economic migrations. This conceptualisation follows the findings of Dorothy Solinger and also incorporates the more recent findings of Fei-ling Wang (2005).

Wang's 2005 book, Organizing through Division and Exclusion: China's Hukou System, argues that, "Human organization through division necessarily produces exclusion. Institutional division and exclusion refer to the fundamental fact of any human grouping: people are divided and then organized into hierarchical layers and horizontally coexisting but separated subgroups. ${ }^{, 67}$ Wang offers a typology of institutional division and exclusion that postulates four forms of institutional exclusion. According to Wang, people are divided and excluded because of: 'who they are' (Type 1); 'what they have' (Type 2); 'where they are' (Type 3); or, 'what they have done or do' (Type 4). (Refer to Table 1).

Table 1: Wang Fei-ling's Typology of Institutional Division and Exclusion

\begin{tabular}{|c||c|c|}
\hline Type & People are Divided \& Excluded because of & Examples \\
\hline Type I & Who they are & $\begin{array}{c}\text { Racial, ethnic, linguistic, sexual, \& } \\
\text { religious difference (apartheid \& caste) }\end{array}$ \\
\hline Type II & What they have & $\begin{array}{c}\text { Skills and ownership of resources and } \\
\text { property (wealth) }\end{array}$ \\
\hline Type III & Where they are & $\begin{array}{c}\text { Family associations and their physical } \\
\text { location or birthplace (citizenship \& } \\
\text { hukou) }\end{array}$ \\
\hline Type IV & What they have done or do & Individual work and behaviour (crime) \\
\hline
\end{tabular}

Source: Adapted from Fei-ling Wang (2005) p.10

The Lewis Transition theory is also used by Wang to show the challenges China faces with its massive economic modernisation process. The Lewis Transition states that for

\footnotetext{
${ }^{67}$ Wang, Organizing through Division and Exclusion: China's Hukou System, p.4.
} 
an economy to move from premodern economic arrangements (characterised by a large agricultural population) to modern economic arrangements, the surplus labour created by the modernisation of agriculture must be absorbed in newly created industrial and urban employment through a process of urbanisation. ${ }^{68}$ Wang shows that in China, where there is extreme regional and rural urban economic disparity, ${ }^{69}$ the challenge of the Lewis Transition is managing that urbanisation so the predominantly rural population do not swamp the cities and bring down wages for the newly industrialising areas as predicted by 'push and pull' models of migration. ${ }^{70}$ The PRC government maintains the role of the huji system to avoid this problem in its urban areas by severely limiting permanent migrations through quotas and attempting to circumvent the Lewis Transition. ${ }^{71}$ By focusing on what has been described as 'urbanisation from below', the PRC government has attempted to circumvent the Lewis Transition so as to protect the newly industrialised areas of the economy from the excess labour pool. ${ }^{72}$ They have done this through the creation of town and village enterprises (TVE), ${ }^{73}$ and the blocking of permanent hukou changes from rural to urban areas. Wang argues that the hukou system, “...has allowed the PRC to circumvent the so-called Lewis Transition and hence to enjoy rapid economic growth and technical sophistication in a dual economy with the existence of a massive surplus labor..." ${ }^{, 74}$ However, the advent of the "floating population' (non-hukou permanent migrants and sojourners in urban areas) has shown that the huji system, whilst effectively maintaining control of permanent migration in China, is also facing severe strains due to non-compliance.

\footnotetext{
${ }^{68}$ W. A. Lewis, The Theory of Economic Growth (London: Allen and Unwen, 1955).

${ }^{69}$ Fan, "Of Belts and Ladders: State Policy and Uneven Regional Development in Post-Mao China."

${ }^{70}$ Lee, "A Theory of Migration."

${ }^{71}$ Wang, Organizing through Division and Exclusion: China's Hukou System.

${ }^{72}$ Laurence J. C. Ma and Chusheng Lin, "Development of Towns in China: A Case Study of Guangdong Province," Population and Development Review 19, no. 3 (1993).

73 乡镇企业

${ }^{74}$ Fei-Ling Wang, "Brewing Tensions While Maintaining Stabilities: The Dual Role of the Hukou System in Contemporary China," Asian Perspective 29, no. 4 (2005), p.99.
} 
Wang cautions against viewing the huji system as a temporary feature of the Chinese bureaucracy and shows through historical analysis the long history of the huji system in China and concurrently the legitimacy that brings. Wang conceptualises the huji system as a predominantly Type III form of institutional exclusion that excludes (and includes) people on the basis of 'where they are'. Wang further argues that the huji system, since the advent of China's 'reform and opening' in the early 1980s, has begun to incorporate Type II forms of institutional exclusion and now also excludes (and includes) people on the basis of 'what they have'. Two of Wang's overriding conclusions are that firstly, China's huji system has a long historical legacy, with many people having invested interests in the system and for this reason the huji system is likely to remain for the foreseeable future. Secondly, "[t]he PRC hukou system, as a Type 3 institutional exclusion based on location differences (where one is), is gradually shifting toward a Type 2 institutional exclusion based on fault lines between haves and have-nots (what one has)." 75 The first of Wang's conclusions directs this study to take note of path dependence and institutional stability/'stickiness'. The second of Wang's conclusions directs this study to utilise Wang's conceptualization of change (the move from exclusive Type III institutional exclusion to Type III institutional exclusion with elements of Type II institutional exclusion) as the conceptual framework for institutional change in China's huji system over the period 1978 to 2007. Wang argues that further research is needed to study the 'adjustments, political dynamics and evolution of the institutional arrangements' ${ }^{76}$

This research seeks to directly address this deficit by seeking to explain the dynamism of change in institutional arrangements of the huji system by utilising Solinger's variables (markets, migrants, the huji system) and the theoretical concept 'agency and

\footnotetext{
${ }^{75}$ Wang, Organizing through Division and Exclusion: China's Hukou System, p.26.

${ }^{76}$ Ibid, pp.30-31.
} 
structure', as well as Wang's typology of institutional exclusion and the incorporation of Type II (what you have) institutional exclusion to the predominantly Type III form of institutional exclusion. This conceptual model of change in China's huji system over the period 1978 to 2007 will be used to structure the collection of data from which to build a theoretical model of the dynamics of this change. This approach is both conducive to the largely inductive methodology of the historical institutionalist approach and to the theoretical and methodological postulates of the grounded theory approach often utilised in studies of Chinese politics.

\subsection{Methodology}

This thesis approaches theoretical model building and field observation by utilising the grounded theory approach. This approach was first identified by Glaser and Strauss. ${ }^{77}$ Kevin J. O'Brien argues that this approach is highly suited to both the unpredictable nature of doing fieldwork in China and to the challenge of applying and testing theory, for most, developed from Euro-American data and observations. ${ }^{78}$ The approach does not set out to falsify (or verify) pre-existing theory but rather requires the researcher to remain open to 'discovery'. For precisely this reason, the conceptual framework outlined above intentionally does not postulate a hypothesis that argues how and why the huji system has changed during the period 1978 to 2007 . Rather, it identifies three interdependent variables (markets, migrants and the huji system itself) and seeks, through field observation and data collection, to explain how formal institutional change is related to these other variables. The 'discovery' of how these variables relate to each other will form the basis of the construction of a theoretical model of institutional change in the huji system over the period 1978 to 2007.

\footnotetext{
${ }^{77}$ Barney G. Glaser and Anselm L. Strauss, The Discovery of Grounded Theory: Strategies for Qualitative Research (New York: Aldine, 1967).

${ }_{78}$ Kevin J. O'Brien, "Discovery, Research, (Re)Design and Theory Building," in Doing Fieldwork in China, ed. Maria Heimer and Stig Thogersen (Honolulu: University of Hawai'i Press, 2006).
} 
Theoretical model building will be based on findings from existing studies and empirical data from three cases. Documentary and written sources will be collected in China and data generated from the raw materials to demonstrate the exact nature of the relationship between the movements of migrants and changes in law, government policy and regulations regarding people's movement and residency. The first case study will be at the central government level and the remaining two city level case studies in Beijing and Shenzhen. The second and third case studies are chosen because of their varying socio-economic status and divergent politico-economic arrangements. The rules and operation of the huji system in 1978 will be used as a baseline for identifying formal institutional change. Significant deviations from this baseline model are indicated by a change of policy, a change of implementation of policy or a change in the institutional objectives of the designers of the institutional policy. This will be measured by analysis of central and local government directives, local and central government plans, hukou registration statistics (agricultural/non-agricultural, huji/non-huji) and inward hukou transfer rates and nongzhuanfei. Economic change will be measured rural/urban growth rates, regional growth rates (east, central, west), employment and growth by three strata industries, national GDP growth and factors indicating the Lewis Transition. Migration and urbanisation will be measured primarily by rural urban population growth and intra and inter provincial migration rates.

Collecting data and doing fieldwork in the PRC is subject to the general problems in quantitative research (availability of data; quality of data; selection of data), but also has the added challenge of being 'subject to many political restrictions' ${ }^{79}$ Therefore, access to data and interviews with officials in the PRC remains problematic. For this reason the grounded theory approach and a wide variety of differing data collection methods will

\footnotetext{
${ }^{79}$ Stig Thogersen and Maria Heimer, "Introduction," in Doing Fieldwork in China, ed. Maria Heimer and Stig Thogersen (Honolulu: University of Hawai'i Press, 2006), p.3.
} 
be utilised. Fieldwork will be utilised to gain a better understanding of how officials and migrants experience and conceptualise China's transition, to avoid excessive western bias and to gain invaluable insight into the political changes occurring in China. Economic development and the reintroduction of markets will be measured using standard economic indicators. Economic migrations will be measured using census studies and statistics from the National Bureau of Statistics of China. However, statistics of migration levels vary greatly. ${ }^{80}$ Whilst the analysis of this data relies on 'discovering' the relationship between the three variables, it is also accepted that the explanation of the dynamism of institutional change has often been criticised as deterministic and open to selection bias. For this reason, the conceptual framework outlined above will remain secondary to the arguments, insights and causal attributions of those institutional actors and institutional architects of the system itself. This research is not intended to establish a theory of development but rather to put forward an explanation for the formal institutional change in the huji system. It is hoped that through this study the dynamics of institutional change in the huji system will be illustrated and provide some insight into areas of future research that can undertake more in-depth studies of China's development model. This research will allow us to have a better understanding of the dynamics of institutional change in a transitional society.

\footnotetext{
${ }^{80}$ Daniel Goodkind and Loraine A. West, "China's Floating Population: Definitions, Data and Recent Findings," Urban Studies 39, no. 12 (2002).
} 


\section{Economic Development and Internal Migration}

This chapter is an overview of the changes that have occurred in the institutional 'environment' of the huji institution. The focus is on explaining the major socioeconomic changes that have occurred over the reform era. The first section looks at economic development and is structured into three parts. The first part takes a broad look at the concept of transitional economies. This is then followed by a more detailed overview of the thirty years of economic reform highlighting the most significant economic changes that have occurred. The last part puts forward a central tenant of this thesis, that these economic reforms have unshackled massive rural to urban and west to east labour migrations. The second section focuses on internal migration in China. A brief history is followed by a summation of the demographics of contemporary internal migration patterns. A closer look at nongmin migrants and the well documented claims that these migrants are subject to discrimination, abuse and exploitation in China's urban areas is followed by an overview of migrant agency, migrant networks and examples of migrants self-organising outside the formal institutional arrangements of urban governments. Finally, a brief conclusion summarises the major findings of the chapter.

\subsection{Economic Development and the Reform Era}

China's stunning economic development over the period of reform and opening has caught the eye of developing and developed countries alike. For the developing world, China's model of growth, like Japan's, Taiwan's and Korea's previously, has come to form the economic basis of what many developing countries are hoping to emulate in their own development projects. For the developed world, China is no longer dismissed 
as the 'sick man of Asia" ${ }^{81}$ and is now an integral part of the global economic system attracting high levels of FDI and maintaining high levels of economic growth as well as healthy balance of trade surpluses and loans with the developed world. China's economic success is particularly striking when considering the situation prior to the reform era. Whilst many successes were experienced in the pre-1978 period, such as improving literacy and abolishing discriminative pre-modern practices such as foot binding, much slavery and polygamy, since China's self-professed drive to modernisation began in the 1840s China has experienced many setbacks, impediments and false starts.

In 1792 Lord Macartney led an embassy to China to negotiate a treaty of commerce and establish a British Embassy in Beijing. At that time China was the largest and most significant economy in the world and the Qianlong Emperor, stating that China had all things, saw no need for British manufactures and rejected all of Macartney's requests. ${ }^{82}$ China was experiencing one of its most expansive eras (conquering Xinjiang and Tibet, defeating the Western Mongolians and forcing concessions in the South), and the Qianlong Emperor presided over an inward looking confident 'Middle Kingdom' that viewed non-Chinese civilisation as uncivilised, barbaric and backward in comparison to the Confucian standards of China's long and glorious civilisation. In hindsight it appears that, “...China was pressing up against the limits of economic possibility given traditional technologies — creating severe crisis_-just at the time when a massive challenge was developing from the West." ${ }^{.83}$ The defeat of China's forces at the hands of the British Empire in the First Opium War (1839-42) and a combined set of forces in the Second Opium War (1856-60), the Taiping Rebellion that swept over southern

\footnotetext{
81 亚洲病夫 The 'sick man of Asia' is a term referring to a weakened China after the Qing Dynasty defeats and concessions at the hands of Western and Japanese powers.

${ }^{82}$ Macartney's mission also refused to follow Chinese protocol governing tribute missions.

${ }^{83}$ Barry Naughton, The Chinese Economy: Transitions and Growth (Cambridge: MIT Press, 2007), p.40.
} 
China in the 1860 s, the colonisation of much of China's tributary regions and the First Sino-Japanese War (1894-95) all pressed the need for reform in China. The 'SelfStrengthening Reforms' that began in the 1860 s followed the philosophy of 'Chinese studies for the base, Western studies for use' but ultimately the failure of the 'Hundred Days of Reform' (suspended before being totally implemented) illustrated the ruling Dynasty's inability to incorporate new forms of foreign science, technology and philosophy and reform the basis of Chinese governance and economy. ${ }^{84}$ The ailing Qing Dynasty fell in 1911, ushering in one of China's most unstable and revolutionary eras.

Post-revolution China became a divided and contested sphere further postponing any modernisation attempts. Warlordism, the foreign concessions, the disastrous Second Sino-Japanese War (1937-45) and the crippling Civil War (1927-50) between the Nationalists and Communists again delayed China's modernisation projects and its ability to steadily build up its economic infrastructure and grow the economy. During this period 'Constitutionalism', the 'May Fourth Movement', the 'Three Principles of the People' and the 'New Life Movement' all attempted reforms but were severely hampered by the political environment. ${ }^{85}$ After the establishment of 'New China' (1949) further setbacks were experienced as the new government maintained an isolationist and reactionary international position and embarked on an overly ambitious and ultimately restrictive model of state socialism and economic planning following the revolutionary political philosophy of Marxist-Leninism and Mao Zedong Thought. Mao's proclamation that 'letting a hundred flowers blossom and a hundred schools of thought contend' was the way to ensure progress during the 'hundred flowers campaign' was quickly retrenched in favour of stability and control. ${ }^{86}$ The ideological alignment with

\footnotetext{
${ }^{84}$ 自强改革、中体西用、百日维新.

85 宪法主义、五四运动、三民主义: 民生、民权、民族 (Three Principles of the People: livelihood, democracy, nationalism)、新生活运动.

${ }^{86}$ 百花齐放, 百家争鸣; 百花运动.
} 
the Soviet Union and the focus on socialist modernisation encapsulated by the slogan 'the Soviet Union today is our tomorrow' also faded as relations between the two powers worsened after the death of Stalin. The Great Leap Forward (1958-60) and the Great Proletarian Cultural Revolution (1966-76) saw pragmatic considerations put aside in favour of ideological fervour with disastrous consequences. Emerging from decades of stunted politico-economic development after the death of Mao in 1976 and the reinstatement of civil order and the constitution, China embarked on an ambitious series of reforms that over a short 30 year period took the nation by storm and revolutionised the way of life in China.

\subsubsection{China in Transition}

The period 1978-2007 is widely regarded and described as China's ongoing 'transition' period. ${ }^{87}$ The period of transition begins as liberal reformers within China's party-state slowly gain the upper hand and with the guidance of paramount leader Deng Xiaoping introduce a series of policy changes often termed the policy of 'reform and opening'. These policies have done much to integrate China into the global economy and led to dynamic changes within China's domestic economy. Whilst the term transition is often left undefined and open-ended, a brief survey of the literature shows that its use generally refers to a move from a planned economy and autocratic governing regime (as well as a reactionary international power) towards a more liberalised economy and polity integrated and participating in the existing international economic and political structure. The term is commonly used when describing the move in Russia and Eastern Europe towards a more liberalised economy and polity after the fall of the socialist

\footnotetext{
${ }^{87}$ See for example: Lisa A. Keister, "Adapting to Radical Change: Strategy and Environment in PieceRate Adoption During China's Transition," Organization Science 13, no. 5 (2002), Steven M. Goldstein, "China in Transition: The Political Foundations of Incremental Reform," The China Quarterly, no. 144 (1995), Peter Nolan, Transforming China: Globalization, Transition and Development, Anthem Studies in Political Economy and Globalization (Anthem Press, 2004), Dorothy J. Solinger, "China's Urban Transients in the Transition from Socialism and the Collapse of the Communist 'Urban Public Goods Regime'," Comparative Politics 27, no. 2 (1995), Zhongwei Zhao and Fei Guo, eds., Transition and Challenge: China's Population at the Beginning of the 21st Century (New York: Oxford University Press, 2007).
} 
regimes. ${ }^{88}$ Communism, command economics and socialist governance came to an abrupt end in these states making the transitional period revolutionary in character.

In China, however, there was no 'big bang' and the economy has incrementally liberalised and markets flourished with steady adaptation to market conditions but limited political liberalization. China's transitional era and the reforms that created the 'socialist market economy' ${ }^{89}$ prioritised agricultural modernisation, development of the private economy, greater use of surplus labour, and the attraction of foreign direct investment in China's coastal urban areas and industrial parks whilst concurrently maintaining many of the organs and institutions of the socialist planned economy. "Those who conceived the reform process in China believed in creating the new economic system around the old. They did not begin by destroying the old institutions and structures so that the new ones could supplant them. Hindsight reveals that this strategic philosophy served China exceedingly well." 90 Rather than dismantling the existing economic planning arrangements the market economy grew alongside the existing command economy, a phenomenon Barry Naughton termed 'growing out of the plan'. ${ }^{91}$ Naughton's influential 1995 book analyses these structural changes over the early reform period and describes the dual-track approach Chinese planners took to reform. Naughton argues that their intention was to avoid the 'big bang' model of reform in order to avoid the risk of compromising the stability of their leadership through short-term inflation and high unemployment and instead chose to freeze the absolute size of the centrally planned economy whilst allowing the market economy to grow alongside it. "Given the obvious fact that the economy was growing rapidly, this

\footnotetext{
${ }^{88}$ See for example: Arch Tait, Russia--Lost in Transition : The Yeltsin and Putin Legacies (Washington, D.C.: Carnegie Endowment for International Peace, 2007).

89 社会主义市场经济.

${ }^{90}$ Dilip K. Das, The Chinese Economic Renaissance: Apocalypse or Cornucopia? (New York: Palgrave MacMillan, 2008), p.9.

${ }^{91}$ Naughton, Growing out of the Plan: Chinese Economic Reform, 1978-1993.
} 
implied that the plan would become proportionately less and less important until the economy gradually grew out of the plan." 92 Due to the freeze on the traditional planned economy any future growth in state companies and private industries would rely on the market, making the dual-track model a transitional model for the marketization of China's economy. Since the reform period began China has experienced 30 years of reform and transition with stunning material results.

\subsubsection{Thirty Years of Economic Reform}

"While the transition process still has a long way to go, the Chinese economy underwent multiple and sizeable transformations, namely, from a command economy to a private-sectorled decentralized market-orientated economy, from a rural-agrarian to an urban-industrial society, from a low-income to a lower-middle-income (as defined by the World Bank) economy and from an autarkic to an open economy. ${ }^{\prime \prime 3}$

The reform era can be seen as a continuation of the 'four modernisations' programme (agriculture, industry, defence and science and technology), first envisaged and implemented by Premier Zhou Enlai in 1964 but interrupted by the anarchy of the Cultural Revolution. After order was again established and paramount leader Mao Zedong had passed away, the necessity of reform was again revisited. The urgency of China's economic situation spurred the Chinese leadership to take a different approach to the question of modernising China. The failure of the Cultural Revolution and the deep dissatisfaction it created amongst the people of China allowed the Party to distance itself from the old revolutionary guard and to put aside old ideological bias. The failures of the planned economy, the stunning successes of the 'Four Tigers' (Taiwan, Hong Kong, Singapore and South Korea), and the untold waste of the ideological campaigns of Mao and the Gang of Four, all “...demonstrated to the Chinese government officials and the Chinese people that a market economy works better than a planned economy." 94

\footnotetext{
92 Ibid, p.9.

${ }^{93}$ Das, The Chinese Economic Renaissance: Apocalypse or Cornucopia? p.3.

${ }^{94}$ Gregory C. Chow, China's Economic Transformation: Second Edition (Oxford: Blackwell Publishing, 2007), p.46.
} 
Through experimentation, ${ }^{95}$ pragmatism, ${ }^{96}$ tenacity and hard work, the people of China have successfully transformed an ailing planned economy into a dynamic market economy for enormous material and social gain.

The reform era policies are now well known and extensively written about. ${ }^{97}$ The following is a brief review of the most significant of them paying particular attention to those related to migration trends. Reform came about through a combination of topdown central government policy and regulation changes and the efforts of the Chinese people and local governments to improve their economic situation. ${ }^{98}$ China's gradual move from an isolated command economy to a dynamic and open market-orientated economy was achieved through agricultural and state-owned enterprise reform and a regional developmental model. Foreign trade and foreign direct investment have been stimulated and the non-state economy has created market conditions leading to price reform, banking system reform, education and legal reform as well as the diffusion of market-orientated economic practice. One reform central to the growth of the internal migrant population was the early reform of China's agricultural sector.

Mao's collectivisation of China's agricultural sector is regarded as a failure even if the tragedy of the Great Leap Forward (1958-60) is put aside. By collectivising the rural labour force Mao tried to bring as much of the productive forces under central and local leadership as possible to improve rural efficiency through a socialist division of labour and by conferring on central planners the means to direct and plan economic exchange.

\footnotetext{
95 实事求是 Seek Truth From Facts; 摸着石头过河 Crossing the river by feeling for stones.

96 不管白猫黑猫, 会捉老鼠就是好猫 One should not care if a cat is black or white as long as it catches mice.

${ }^{97}$ See for example: Naughton, The Chinese Economy: Transitions and Growth, Chow, China's Economic Transformation: Second Edition, Das, The Chinese Economic Renaissance: Apocalypse or Cornucopia, Kevin Honglin Zhang, ed. China as the World Factory, Routledge Studies in the Growth Economies of Asia (New York: Routledge,2006), Loren Brandt and Thomas G. Rawski, eds., China's Great Economic Transformation (New York: Cambridge University Press,2008).

${ }^{98}$ Chow, China's Economic Transformation: Second Edition.
} 
However, collectivised farms continually failed to produce the expected gains in productivity. After they were dismantled it became clear that they were far less productive than family/individual farming which increased China's food production almost immediately after reintroduction. Formal reintroduction began with Zhao Ziyang's experiments in Sichuan where decollectivised farming methods were a success in the 1970 s and Deng Xiaoping sought to emulate this. Overall, the process was predominantly bottom-up and officially adopted by the Fourth Plenum of the Eleventh Central Committee of the Communist Party in September 1979.

"Farmers attempted unorganized decollectivization, or surreptitious grassroot land reform in many parts of rural China throughout the 1960s and 1970s. Their efforts finally succeeded in the late 1970s and came above ground when Deng Xiaoping eventually accepted this alternative to Mao's collectivism. He named it the 'household production responsibility system' in order to avoid the term 'decollectivization.",99

Once China's rural areas returned to family-based farming practices and rural people were again allowed to sell above quota grain in markets and raise their own stock as sideline businesses (banned during the Cultural Revolution as capitalist), China's rural areas were swept by a wave of entrepreneurialism and a return to China's long tradition of rural and town markets began. New efficiency and the modernisation of existing practices uncovered the unemployed and underemployed pool of rural labourers. It is unclear if Deng also believed this reform would provide the labour force for China's economic development. If so, it was a stroke of political genius on his part, especially considering the institutionalised division of rural and urban worlds and the legacy of state planning he inherited. It is perhaps more likely, as Hein Mallee argues, that Deng was experimenting and reacting to existing trends of rural workers migrating in search of casual work. Irrespective of Deng's motivations, the effect of returning to familybased farming was to unshackle China's most significant natural resource, its large rural

\footnotetext{
${ }^{99}$ Daming Zhou, How the Farmers Changed China: Power of the People (Boulder: Westview Press, 1996), pp.4-5.
} 
labour force. By also undergoing significant state enterprise reform and encouraging a market economy to grow the Chinese leadership created the institutional environment conducive to the realisation of the value of that resource.

Before the reform period the state sector was the only significant driver of the urban economy. Morris Bian (2005) argues that this system of centrally-planned state-owned production, the bureaucratic governance structure, the management and incentive systems and the provision of social services and welfare (what Solinger describes as the 'urban rationing regime'), developed during the crisis of the Second Sino-Japanese War (1937-45) and is not a legacy of the Soviet planners as commonly attributed. Bian argues that this crisis forced the Nationalist elite to recognise the inadequacy of China's institutional arrangements and to develop new shared mental models, including the ideology of a development state. This took form during the war and became the underpinnings of the state enterprise system. ${ }^{100}$ This system functioned within the command economy and led New China's development and modernisation goals. However, by the 1970s it was clear to many that the system was inefficient, under producing and not delivering economic growth to develop China and provide for its people. Again, Deng's leadership and the policymakers of the day chose experimentation as the way of finding the best way forward.

"Industrial reform had begun in late 1978 with six pilot enterprises in Sichuan Province. By the end of June 1980, 6,600 industrial enterprises that had been allowed to make certain output, marketing, and investment decisions through partial profit retention had produced in value 45 percent of the output of all state-owned industrial enterprises. By the end of 1981 some 80 percent of state-owned industrial enterprises were involved in the reform experiment. ${ }^{, 101}$

Even though experimentation, as with agriculture, proved successful, many members of the Party were unwilling to privatise the state sector fully as they were unwilling to

\footnotetext{
${ }^{100}$ Morris L. Bian, The Making of the State Enterprise System in Modern China: The Dynamics of Institutional Change (Cambridge: Harvard University Press, 2005).

${ }^{101}$ Chow, China's Economic Transformation: Second Edition, p.50.
} 
surrender control and ownership of state assets and did not want to see private interests retain profits. Furthermore, state enterprises were an integral part of the command economy and so it was not possible to privatise them fully without also reforming the entire economic planning system, including price fixing, the banking system and financial system. Planners instead chose to give individual state enterprises more autonomy in decision making (planning, output, investment), introduce an 'economic responsibility system, ${ }^{102}$ (units within the enterprise were paid according to productivity), introduce limited supply and demand forces and encourage a move towards collective ownership of the enterprises (as opposed to state ownership), what Das describes as a 'process of creative destruction. ${ }^{103}$ They created the conditions for the development of new private industry that replaced the old state sector industry gradually allowing the importance of SOEs to be wound down slowly.

On October 20, 1984 the Twelfth Central Committee of the Chinese Communist Party nationalised the policies of the reform experiment. They gave individual state enterprises autonomy in decisions regarding production, supply, marketing, pricing, investment and personnel 'to function as profit-seeking economic units'; they reduced the scope of central planning, except in major projects, and changed planning from mandatory to guidance planning; they allowed prices of more products to be determined by the forces of demand and supply rather than central control; they developed macroeconomic control mechanisms through the use of taxes, interest rates, and monetary policy under an improved banking and financial system; they established various forms of economic responsibility systems within individual enterprises to promote efficiency and to institute differential wage rates to compensate for different kinds of work and levels of productivity; they fostered the development of individual

\footnotetext{
102 经济责任制.

${ }^{103}$ Das, The Chinese Economic Renaissance: Apocalypse or Cornucopia?
} 
and collective enterprises as supplements to state enterprises; and they expanded foreign trade and investment and promoted technological exchanges with foreign countries. ${ }^{104}$

The 'contract responsibility system' adopted in 1987 and calls from Jiang Zemin in 1997 and others earlier, such as Zhao Ziyang who promoted the idea of private shareholders for state enterprises, further changed the way state enterprises operated. At the same time, private enterprises (individual-owned, collective-owned and foreign joint ventures), further changed the way state enterprises operated by introducing market imperatives to the overall economy. Figure 1 shows the increasing importance of private industry relative to state sector industry over the first two decades of the reform era with state enterprises dropping from close to $80 \%$ of all industrial output in 1978 to under $25 \%$ in 1996.

Figure 1: Gross Industrial Output of State and Non-State Enterprises

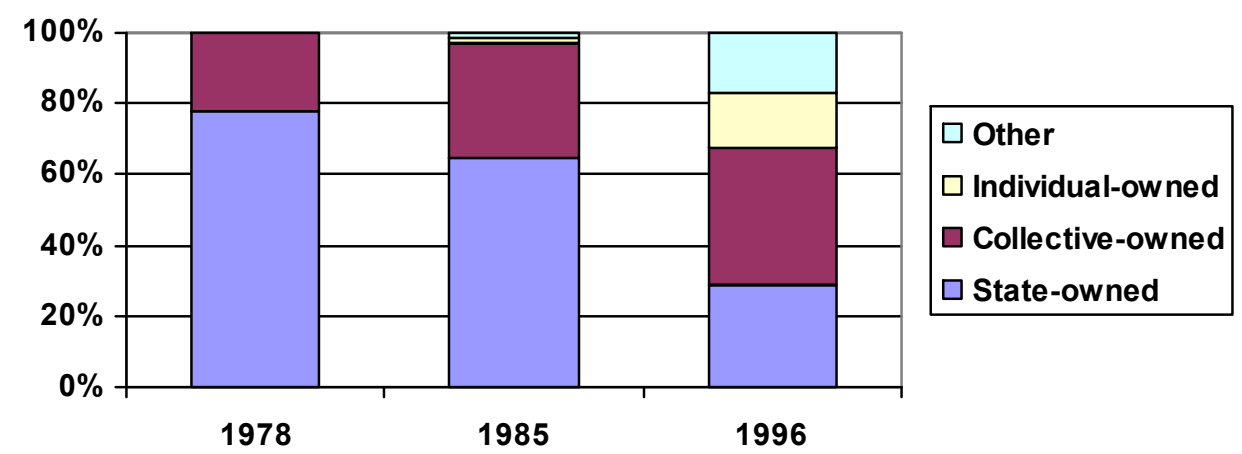

Source: Adapted from Table 3.1 of Chow (2007)

As the private economy has grown, banking, price and finance reforms have been implemented. Price reform began with an October 1984 decision by the Central Committee of the Communist Party. Its main objective was to decontrol the administratively determined prices gradually and allow prices to be determined by market forces. As with state sector reform, a two-tiered system was employed. Fixed prices were maintained but limited as market prices were introduced. State enterprises

${ }^{104}$ Chow, China's Economic Transformation: Second Edition. 
that wanted to buy/sell above their planned production could do so within the market. Private industry could also utilise market prices. Fixed prices were diminished gradually so as to minimalise the disruption to state enterprises and the urban public accustomed to set prices for food and products, subsidised housing and life essentials. Gradually market prices have come to be the dominant price system in the Chinese economy.

Banking reform also occurred in the early reform era. In 1983, the only bank in China at the time, the People's Bank of China, was transformed into a centralised bank and a group of specialised banks with autonomy to extend credit. This led to the rapid supply of currency financing the reform era. Then in 1993, the Third Plenum of the Fourteenth Central Committee of the Communist Party gave more independence to the central bank and transformed the specialised banks into commercial banks. The 1995 Law on the People's Bank of China and the Commercial Banking Law provide a blueprint of the Chinese banking system. It is noted, however, that banking sector reform is still required in China and that even after thirty years of reform the provisions of the 1995 laws are not actually carried out in practice. This is but one example from China that "demonstrates the rule that institutions cannot be changed through legislation alone." 105 The reform of the Chinese state sector is another example. As the state sector went through the reform process it was clear that its success was determined not only by government leadership but also by the work of people in state enterprises and local governments. The growth of private industry is a dramatic example of how the people of China pushed for and responded to government encouragement of private industry, commerce and trade and created one of the most dynamic private economies of the contemporary world from a stagnating command economy.

${ }^{105}$ Ibid, p.54. 
China's leadership has successfully given more individual autonomy to the state sector and gradually introduced market reforms. Even though these reforms have not been entirely successful this form of gradualism has allowed the private sector to grow and given China's rural migrants the opportunity to be involved in a dynamic and growing market economy. Without the growth of the private economy this would not have been possible. The growth of the private sector stems from the collectivisation of existing state owned enterprises. Collective enterprises were often originally state owned before transfer to a collective and then leased to private or collective owners who operated at a profit. TVEs in rural areas were established with the support of local governments (looking for increased revenue). Local officials were often involved to ensure contracts were honoured and red tape was avoided as well as to stimulate local development (corruption was also rife). New collective commercial and industrial enterprises were also formed in urban areas. These enterprises have been very successful and have come to represent more value creation for China than the once exclusive state sector.

The growth of the private sector has been particularly impressive on the eastern coast of China due to a regionally targeted planned opening to market forces and international finance and trade markets. During the Mao era China's regional development policy was driven by two goals: regional equity (involving redistributive policies that moved wealth from the coast to the interior) and defence (involving development of Third Front regions in the interior less vulnerable to foreign attacks). Mao's policies, whilst bringing some regional equity to China, failed to promote productivity or efficiency and thus this development model was a disaster for China's developing economy. In postMao China, policymakers adapted Chinese socialism to the government's new priorities and coined the theory of the 'primary stage'. Policy makers argued that because the communist revolution occurred whilst China was economically underdeveloped and 
'full socialism' presumes 'mature socialist societies', the primary stage of 'socialism with Chinese characteristics' required an acceleration of national economic growth to alleviate poverty. In 1984 Deng Xiaoping described the policy as follows:

"We have said that socialism is the primary stage of communism and that at the advanced stage the principle of from each according to his ability and to each according to his needs will be applied. This calls for highly developed productive forces and an overwhelming abundance of material wealth. Therefore, the fundamental task for the socialist stage is to develop the productive forces." 106

The theory of the 'primary stage' led to an emphasis on efficiency rather than equity and on open-door rather than self-reliance; ${ }^{107}$ a curious adaptation of socialist ideology and rhetoric to incorporate neoclassical economic theories and other western developmental models. Efficiency for Deng meant promoting modernisation (the Four Modernisations) and the development of markets ('Poverty is not socialism. To be rich is glorious.'). Deng and his policymakers argued that 'some will get rich first' utilising, but never publicly acknowledging, classic capitalist rationale that if some regions or some people get rich first, then they will set an example and create the wealth needed for other regions to follow; meaning a sacrifice of initial economic divergence in the short term for convergence in the long term. The focus on open-door policy was premised on the 'theory of the grand international cycle'. ${ }^{108}$ Chinese policy makers argued that developed countries and the newly industrialised nations were increasingly specialising in non-labour intensive sectors and so China could utilise its large labour force by specialising in labour-intensive export-orientated industries to bring in foreign capital. These priorities, efficiency and open-door, drove the regional development model in the post-Mao years creating stark changes from the Mao era which was driven

\footnotetext{
${ }^{106}$ Xiaoping Deng, "Building a (Sic) Socialism with a Specifically Chinese Character," in Excerpt from a talk with the Japanese delegation to the second session of the Council of Sino-Japanese NonGovernmental Persons (China: People's Daily, 1984).

${ }^{107}$ Fan, "Of Belts and Ladders: State Policy and Uneven Regional Development in Post-Mao China."

${ }^{108}$ Ibid; 国际大循环理论.
} 
by notions of equity, defence and self-reliance. ${ }^{109}$

The sixth and seventh Five Year Plans (1981-1985 \& 1986-1990) first proposed and then formally adopted a three-belt model of development in China. The Eastern Region was to specialise in export oriented industries and foreign trade; the Central Region was to concentrate on agriculture and the energy sector; the Western Region was to focus on animal husbandry and mineral exploitation. The goal of the three belt model was to grow the Eastern Region and have FDI accumulate there and then diffuse to central and western areas. The Eastern Region was targeted for development through a series of 'open zones' to attract foreign investment, ${ }^{110}$ fourteen 'open coastal cities' created in 1984, ${ }^{111}$ and various other open zones. ${ }^{112}$ "In these designated locations, foreign investors were accorded special treatment such as tax exemptions and tax 'holidays'. To promote these zones, the state allocated large investment to enhance their infrastructures; and as state and foreign investments boosted economic growth, these zones became China's newest growth poles or, more vividly, its 'golden coastline'..." ${ }^{\prime 13}$ Figure 2 illustrates these changes.

\footnotetext{
109 Ibid.

${ }^{110}$ Four 经济特区 Special Economic Zones were created in 1979 (深圳 Shenzhen, 珠海 Zhuhai, 汕头 Shantou, 厦门 Xiamen) and one in 1988 (海南 Hainan).

111 秦皇岛 Qinhuangdao, 大连 Dalian, 天津 Tianjin, 烟台 Yantai, 青岛 Qingdao, 连云港 Lianyungang, 南通 Nantong, 上海 Shanghai, 宁波 Ningbo, 温州 Wenzhou, 福州 Fuzhou, 广州 Guangzhou, 湛江 Zhanjiang, 北海 Beihai.

112 Including: 长江、珠江、闽南三角 Yangzi, Zhujiang (Pearl River), and Minnan deltas.

${ }^{113}$ Fan, "Of Belts and Ladders: State Policy and Uneven Regional Development in Post-Mao China." p.426.
} 


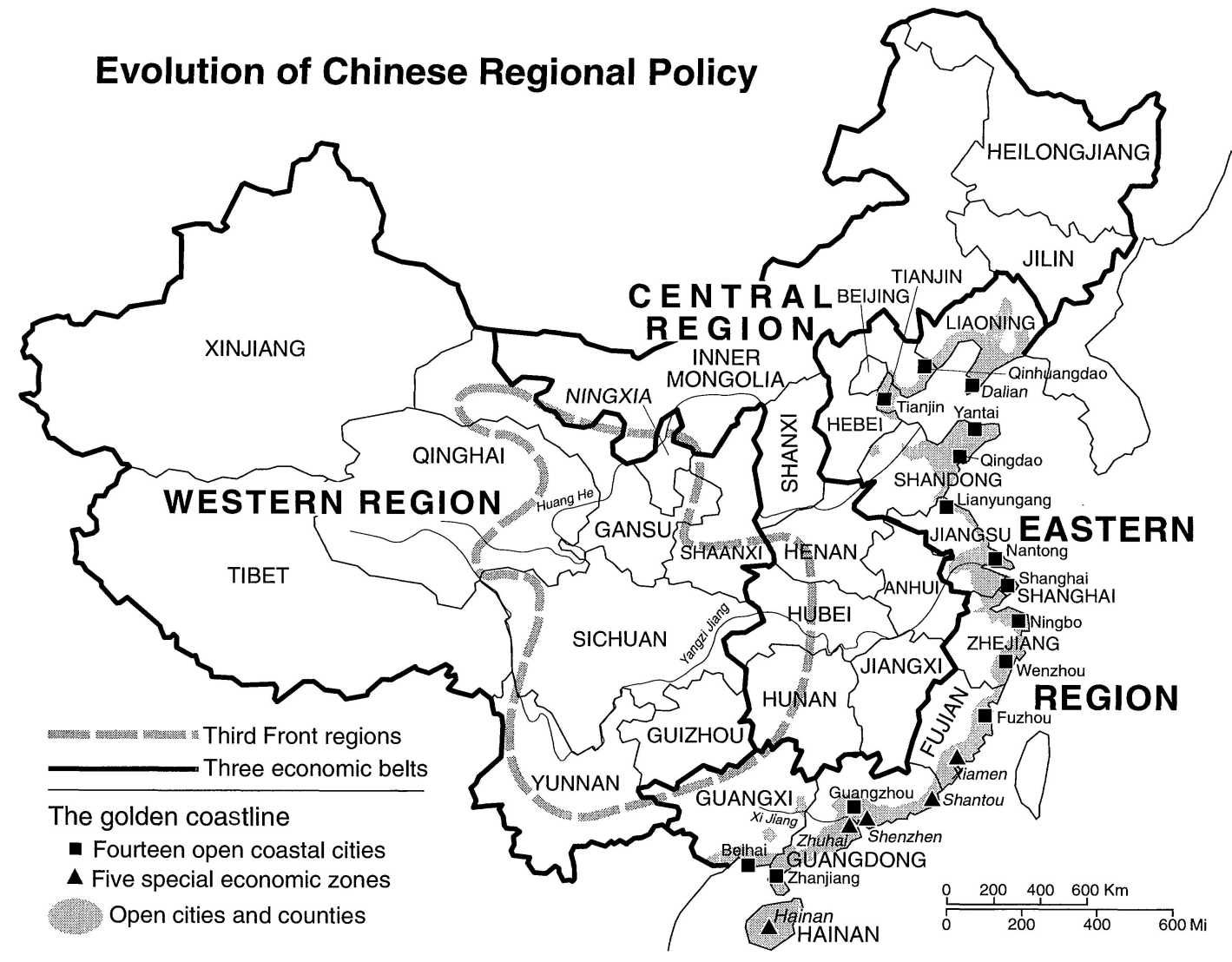

Figure 1. Evolution of Chinese regional policy. Sources: Beijing Review 1986b; Naughton 1988; and People's Daily 1992.

Source: Fan (1995) $)^{114}$

The Eastern Region had five 'preferential policies' 115 to encourage its economic development: firstly, the investment policy meant coastal provinces received more investment from the state; secondly, the foreign-exchange retention policy meant open zones enjoyed higher foreign exchange retention rates; thirdly, the revenue-remittance policy meant some coastal provinces were allowed to remit smaller proportions of their gross revenue to the state; fourthly, the price policy meant primary and agricultural goods were priced substantially lower than finished and industrial products (the 'scissors differential'); and finally, the financial policy meant all provinces were given greater financial autonomy but that coastal provinces and open zones enjoyed greater

\footnotetext{
${ }^{114}$ Ibid. p.423.

115 倾斜政策.
} 
freedom in currency circulation, credits and loans, issuance of construction bonds, and in the establishment of private financial institutions. ${ }^{116}$ This long list of preferential treatment shows the role of the state in this development is crucial to understanding the Chinese economic miracle and the creation of regional differences that act as push and pull drivers of migration.

China's economic reforms have been impressive by any standard. Their success has been attributed to pragmatic leadership not overly subject to ideological constraints; experimentation with programmes to see what works before full implementation; gradualism as opposed to 'shock therapy'; political stability during the reform process; and the support of the Chinese people and government officials who experienced the failure of economic planning. ${ }^{117}$ China's trade grew at an average rate of 15 percent annually between 1978 and 2006. Multilateral trade grew at an average rate of 7 percent over the same period. The growth rate of manufactured exports was 16.9 percent per annum for China over the period 1990-2000. Comparing this to the world average of 6.4 percent, the developing country average of 12 percent and the rest of East Asia at $10 \%$, China's export growth has been nothing short of spectacular. ${ }^{118}$ In 2008, China's economy became the $4^{\text {th }}$ largest in GDP terms measured using the market exchange rate. In PPP terms (Purchasing Power Parity) it is the second largest. It is the third largest trader in the world and it has accumulated the largest foreign exchange reserves of any nation (World Bank, 2008).

China is however still a developing country with a predominantly rural population, weak economic foundation and underdeveloped productivity. The Chinese 'economic

\footnotetext{
${ }^{116}$ Fan, "Of Belts and Ladders: State Policy and Uneven Regional Development in Post-Mao China." p.426.

${ }_{117}$ Chow, China's Economic Transformation: Second Edition.

${ }^{118}$ Das, The Chinese Economic Renaissance: Apocalypse or Cornucopia?
} 
miracle' has radically improved China's material and social wealth but many problems remain and along with the added wealth new problems have been created. Reforms have caused inflationary pressures on the Chinese economy; ${ }^{119}$ they have afforded officials the opportunity to extract bribes through their control of state assets and rights to issue permits; the Asian Financial Crisis (1998) showed a need for further reform in the banking sector; entrance into the WTO has brought to the fore anti-competition suits with the EU and US in relation to dumping; the balance of trade imbalance with the developed world causes friction and some anti-Chinese sentiment. However, perhaps the most pressing issue China faces as a consequence of the reforms is that some in China have gotten rich whilst others have merely risen above the poverty line. Rural poverty and the growing income gap between rural and urban residents have created increasing discontent amongst certain sectors of the Chinese population even though incomes in rural areas have improved substantially since the reform era began. Many rural residents and residents of poorer regions of China argue the central government has treated rural residents unfavourably compared to urban residents and prioritised the development of urban and eastern areas at the expense of the rural people. The rural/urban and regional wealth gaps are important drivers of China's migratory patterns and will form an important part of the case studies explaining adaptation of the huji institution in latter chapters. Figure 3 illustrates the growing rural/urban wage gap.

\footnotetext{
${ }^{119}$ The most spectacular of which occurred prior to the student unrest at Tiananmen: In the late 1980s the banking reforms and monetary policy allowed the rapid increase of the money supply, by 50 percent in 1984 and over 30 percent per year in 1986-8, leading to inflation at an annual rate of 30 percent in the fall of 1988. See: Ibid.
} 
Figure 3: Urban and Rural GDP Per Capita 1978-2006 (Yuan)

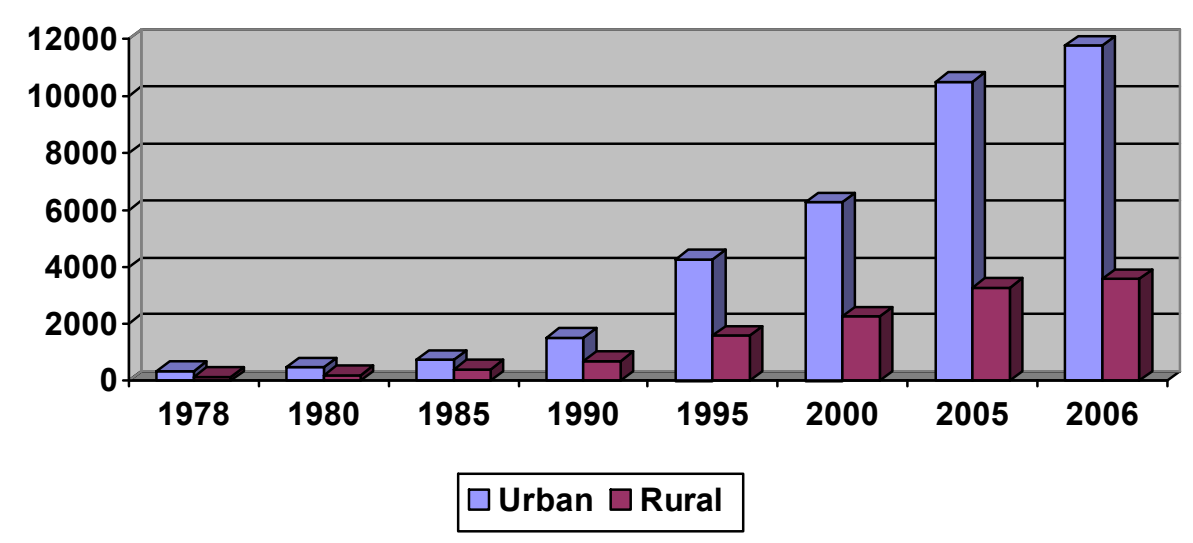

Source: National Bureau of Statistics of China ${ }^{120}$

In light of the growing rural/urban divide, then Premier Zhu Rongji's 2001 comment that continued economic growth is "the key to resolving all problems" is in need of some modification. For China to continue its steady rise out of poverty, greater government focus on the development of rural areas and the central western regions is needed. Government efforts to date include identifying the 'three rural problems" ${ }^{121}$ and a focus in the Eleventh Five Year Plan (2007-2012) to develop rural, central and western regions, including sorely needed infrastructure development. To date, the gap between rural and urban wages still remains one of the highest in the world.

\subsubsection{Unshackling Labour Migrations}

"Since the late 1970s, China benefited from a strong increase in human resources, that is raw labor force. Rural areas in China had considerable surplus of unskilled labor, which still persists. Rural areas have had higher unemployment rates than urban; also large disguised or hidden unemployment has persisted. Therefore, rural areas had, and continue to have, an almost perfectly elastic supply of labor, whose opportunity cost was exceedingly low, almost negligible. This was in keeping with the well-known Arthur Lewis model of economic development. Rural to urban movement of labor has been on the rise. It has helped China in building up and reinforcing its manufacturing-based economic success. ${ }^{1122}$

Chapter one summarised the reforms that unshackled and drove the labour migrations of the reform era into three categories: the end of collectivisation and a return to household

\footnotetext{
${ }^{120}$ National Bureau of Statistics of China, China Statistical Yearbook 2007 (Beijing: China Statistics Press, 2007).

121 三农问题: 农业、农村、农民 Three Rural Problems: agriculture, rural villages and rural people.

${ }^{122}$ Das, The Chinese Economic Renaissance: Apocalypse or Cornucopia? p.15.
} 
farming which unshackled the rural labour population creating a labour surplus; the allowance and acceptance of markets that allowed the rural population to find work, accommodation and purchase the necessities of life in the urban areas; and finally the uneven regional development of China that created push and pull forces directing labour migrants to move to the predominantly coastal regions of high economic growth, high FDI and more private sector activity. The critical shift in economic policy that made so much difference to China's patterns of internal migration came at the very beginning of the reform era, or as some scholars have argued, existed prior to the reform period but remained unseen. ${ }^{123}$ Hein Mallee has argued that migrants took the initiative in the early reform period without government sanction, creating markets in urban areas and becoming involved in the burgeoning market economy and that they were part of the impetus for the reform era policies. ${ }^{124}$ However, in general most scholars mark the beginning of the $1980 \mathrm{~s}$ as the period when internal migration patterns changed as the growth of markets along China's east coast required more labour than the registered urban population could provide (as well as noting that many urban residents were not willing to do many of the newly created low-end jobs).

China's stunning economic growth is predicated on this movement of rural labourers from low-productivity agrarian work to high-productivity manufacturing work. Workers have left the land and moved to the cities at an increasing pace. In 2005 estimated output per worker in agriculture was $\$ 800$ but in industries, manufacturing and utilities it was more than $\$ 5,900$ - more than seven times higher than that in agriculture. ${ }^{125}$ This shows the transfer of labour from agricultural to non-agricultural production has contributed enormously to China's productivity at the macro level, and at the micro

\footnotetext{
${ }^{123}$ Dianny Lary, "The "Static" Decades: Inter-Provincial Migration in Pre-Reform China," in Internal and International Migration: Chinese Perspectives, ed. Frank N. Pieke and Hein Mallee (Cornwall: Curzon Press, 1999).

${ }^{124}$ Mallee, "Migration, Hukou and Resistance in Reform China."

${ }^{125}$ Das, The Chinese Economic Renaissance: Apocalypse or Cornucopia? p. 19.
} 
level it has given China's rural residents ample incentive to migrate to urban areas. As Chen and $\mathrm{Wu}$ (2005) put it, 'Agriculture has become a losing enterprise. ${ }^{126}$ There is strong evidence that the Lewis Transition is operational as shown by the rate of urbanisation over the reform era (see figure 4). ${ }^{127}$ In 1978 roughly $80 \%$ of the population resided in rural areas but by 2005 that number had dropped below $60 \%$.

Figure 4: Percentage of Population in Rural and Urban Areas (1978-2006)

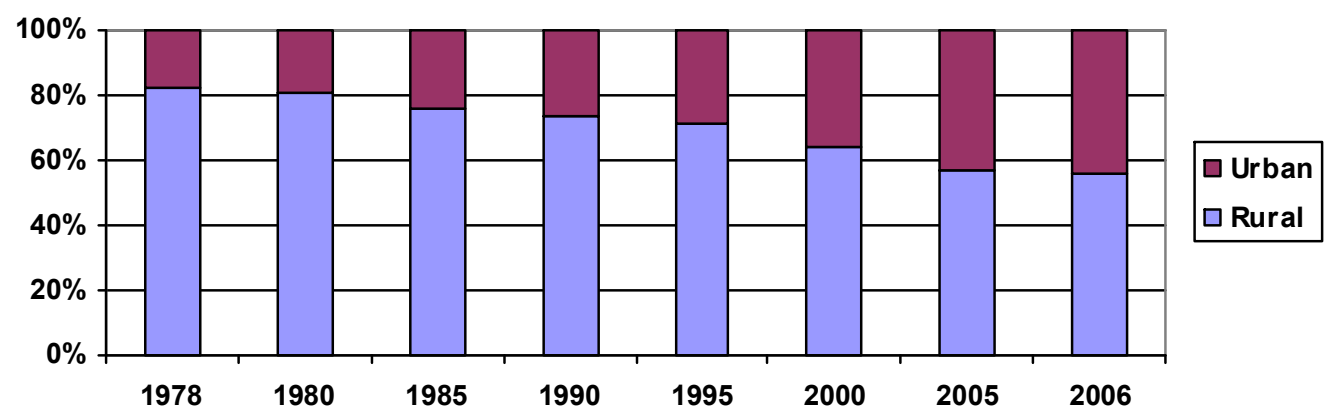

Source: National Bureau of Statistics of China ${ }^{128}$

Xianbi Huang's 2008 study of China's emerging job market also provides evidence that labour is moving from a predominantly planned allocation to the development of a labour market. Huang divides the reform era into two sub-eras: the early reform period (1980-92) featuring the return and emergence of labour markets and the trialling of 'labour contracts'; and the 'further reform period' (1993 on) characterised by the widespread and growing prevalence of job markets, increased voluntary and involuntary job mobility and the advent of massive numbers of rural migrants increasingly competing for jobs with urban residents. ${ }^{129}$

These studies suggest that China is urbanising, modernising and liberalizing but fail to account for the importance of hukou status and its institutional legacy. Many scholars

\footnotetext{
${ }^{126}$ Chen and Wu, Will the Boat Sink the Water? The Struggle of Peasants in 21st-Century China. p.199.

${ }^{127}$ Note: the rate of urbanisation here does not refer to hukou status as determined by the Ministry of Public Security but rather to the population of the urban and rural areas.

${ }^{128}$ National Bureau of Statistics of China, China Statistical Yearbook 2007.

${ }^{129}$ Xianbi Huang, "Guanxi Networks and Job Searches in China's Emerging Labour Market: A Qualitative Investigation," Work, Employment and Society 22, no. 3 (2008).
} 
within China now argue that in order to deepen the reforms and to continue economic development and modernisation, reform of the population control mechanisms is required. They turn their attention to the huji institution as a barrier to continued economic growth and as a hangover of the command economy era. Now that China's economy is market-oriented scholars are questioning the utility of the huji institution and critiquing it as a form of government meddling in the workings of the market, an impediment to greater economic liberalisation:

"China's existing huji institution came into being under the planned economic system and during a special historical period. It is already out of step with the changing situation and falls short of the requirements of reform and opening. It must be reformed as soon as possible. We must smash the urban rural discrimination of the huji system and establish a uniform identity card system.,130

"The huji system and the planned economy are closely linked. The planned economy provided the institutional environment for the huji institution and the huji institution maintains the stability of the planned economy. Since reform and opening, the role of markets in the economy has exerted an ever increasing effect. Structural transition has increased economic efficiency and primed the economy which has also enabled the villages to go through profound changes. However, after releasing short-lived productivity village reform became stagnant. Requirements for further deep reform of the villages have generated demands to reform the huji system ... As long as the huji system exists, a true market economy cannot become established. As a result, huji system reform and complete economic structural reform are unanimous." ${ }^{131}$

However, as later chapters will show, the huji institution is also an indispensable tool for central and local government officials seeking to promote the development of their market-oriented economies. This suggests that the huji system has adapted to the new economic structure but maintained the original function of promoting economic growth, albeit within a vastly different economic development model. China's economic reforms are fundamental to understanding changes to both patterns of internal migration and the functioning of the huji institution. The economic reforms unshackled a dormant force in the Chinese economy-China's rural labourers - and this force is in no small

\footnotetext{
${ }^{130}$ Duan Minfang 段敏芳. "中国人口变迁流动现状及发展趋势" [Current Trends in the Development of China's Migration Flows]. 《中南财经政法大学学报》[Journal of Zhongnan University of Economics and Law] 6, no. 141 (2003), p.20.

${ }^{131}$ Chi Jianyu 池建宇, and Yang Junxiong 杨军雄. "中国户籍制度变迁的供求分析--从农村经济改革 角度作出的一种解释" [Analysis of Supply and Demand in China's Transitional Huji System: An Explanation from the Perspective of Rural Economic Reform]. 《经济体制改革》[Reform of Economic System] no. 3 (2003), p.71.
} 
way responsible for the successes of the reform era. However, by unleashing this force the reforms have also created new challenges for the current leadership, in particular adapting China's age-old huji institution to the new internal migration patterns driven by economic imperatives and the functioning of China's growing market economy. How government officials have responded to these challenges is the subject of later chapters. The next section will briefly overview the demographics of these contemporary migrations and of China's newest socio-economic group (nongmingong) in order to develop in more detail the nature of internal migration during the period of study (1978 - 2007).

\subsection{Internal Migration in the Reform Era}

'Urban China cannot afford to 'open its borders,' nor can it do without the rural labor that crosses them. The Chinese seem to be walking a very fine line between social control and constriction of the urban economy, much as did the United States during the many years when it was illegal to work in the United States without documents, but not illegal to hire someone who didn't have them...." 132

China is experiencing an 'age of migration' of global proportions. China's internal floating population is greater than the population of all but nine of the world's nationstates. ${ }^{133}$ In China's urban areas, as in the receiving states of the global migration wave, a vocal debate has emerged covering issues of citizenship, cultural identity, labour competition, state sovereignty and the relationship between the free movement of capital and trade and the movement of labour. ${ }^{134}$ A comparison of China's 'tidal wave' of migrant labour and Mexican undocumented migration to the United States finds commonality in three general areas: the migration process, the economic and social position of migrants at their destination and the agrarian structure and process of

\footnotetext{
${ }^{132}$ Kenneth D. Roberts, "China's 'Tidal Wave' of Migrant Labor: What Can We Learn from Mexican Undocumented Migration to the United States?," The International Migration Review 31, no. 2 (1997), p.281.

${ }^{133}$ Japan, the tenth most populated nation-state, has a population of nearly 128 million. China's floating population is over 130 million.

${ }^{134}$ See: Ingrid Nielsen, Russell Smyth, and Marika Vicziany, eds., Globalisation and Labour Mobility in China (Victoria: Monash University Press, 2007).
} 
agricultural development perpetuating circular migration. ${ }^{135}$ Moreover, the residency status of China's internal migrants is more akin to that of international migrants with temporary work visas or the illegal migrants increasingly prevalent in the developed world. That academics can utilise findings from studies of cross-border migration to discuss internal migration in China highlights the unique nature of the Chinese nationstate. Fei-ling Wang (2005) argues that migration within most nation-states is influenced by economic and social factors but that in China, government law, policy and guidelines also play a very significant role through the huji institution. ${ }^{136}$

Over the period 1978 - 2007 the huji system has been both enduring and adaptive as 'planned' and 'outside the plan' migration has grown from around 20 million in the early 1980 s to over 130 million in the mid-2000s. After the breakdown of rural collectivisation, China's 'excess' rural labourers moved in ever-greater numbers to urban areas becoming a fundamental ingredient in the success of China's economic growth. As is the case in the response of developed states dealing with the global 'age of migration', the huji system of 2007 has adapted to these migratory and economic conditions but maintained the fundamental function of controlling and regulating settlement. ${ }^{137}$ This section looks briefly at the history of internal migration in China, focusing on cultural norms before covering the demographics of China's 'age of migration' over the period 1978 to 2007. It discusses the question of rights and exploitation of the new 'army' of non-registered migrant workers and concludes by focusing attention on the agency migrants bring to bear on the institutional arrangements of the huji system through migrant networks and self-organisation.

\footnotetext{
${ }^{135}$ Roberts, "China's 'Tidal Wave' of Migrant Labor: What Can We Learn from Mexican Undocumented Migration to the United States?.", Kenneth D. Roberts, "The Changing Profile of Labor Migration," in Transition and Challenge: China's Population at the Beginning of the 21st Century, ed. Zhongwei Zhao and Fei Guo (New York: Oxford University Press, 2007).

${ }^{136}$ See Wang's 'typology of institutional exclusion': Wang, Organizing through Division and Exclusion: China's Hukou System.

137 _ Contemporary China."
} 


\subsubsection{Historical Trends and Cultural Norms}

"The search for demographic data has not yet uncovered good materials to study internal migration. We know the larger parameters of the picture: the late Ming and Qing societies were 'on the move,' where individuals and families migrated in search of better opportunities to earn a living, and where localities developed long-run strategies of temporary emigration (Skinner 1976). The lure of the copper mines caused the population of Yunnan and Guizhou to more than double in the period 1700-1775 (Lee 1982:720). Migration enabled the population of Sichuan, devastated during the Ming-Qing interregnum, to grow rapidly throughout the Qing dynasty (Smith 1988). Taiwan received large numbers of migrants from Fujian, and became sinicized in Qing times. These migrations were part of a large-scale settlement of the frontiers that was a major element of Qing history."138

Internal migration played an important role in China in pre-modern times. Through war, natural disaster and colonisation people have been forced, encouraged or have chosen to migrate to avoid danger or to pursue a better way of life. An early example of this is what William H. McNeill (1984) describes as the best example of civilised agricultural pioneering - the colonisation of what is now central and southern China through superior rice paddy agriculture and water engineering. ${ }^{139}$ An early example of migration for political expansion is the colonial migrations of Han Chinese during the reign of Qin Shihuang to southern China following the unification of China. ${ }^{140}$ However, the extent and details of premodern migrations remains unclear. What is clear is that migration occurred in opposition to various cultural norms. "In China, Confucian values reinforce the relative lack of mobility among the traditional population..." ${ }^{141}$ The common Confucian proverb when your parents are alive, one should not stray far from home, ${ }^{142}$ highlights a traditional propensity of people in China to view migration as undesirable. This is explained by Liang and Ma (2004) as an integral part of the Confucian value 'filial piety'. ${ }^{143}$ Mara Caira (2008) extrapolates on this theme and argues that the act of internal migration in China, then and today, means going against the dictates of the state (defined as legal and illegal migration) and in most cases creates issues for the migrant

\footnotetext{
${ }^{138}$ Evelyn S. Rawski, "Research Themes in Ming-Qing Socioeconomic History--the State of the Field," The Journal of Asian Studies 50, no. 1 (1991), p.94.

${ }^{139}$ William H. McNeill, "Human Migration in Historical Perspective," Population and Development Review 10, no. 1 (1984).

${ }^{140}$ J. A. G. Roberts, A History of China, 2nd ed. (New York: Palgrave Macmillan, 2006). p.24

${ }^{141}$ Liang and Ma, "China's Floating Population: New Evidence from the 2000 Census." p.475.

142 父母在不远游 cited in Ibid, p.475.

143 孝顺、孝道.
} 
due to ethnic identities and family ties.

"Separation from ancestral land was felt as a deep chagrin because of the strong link to familiar and clan relations, which all Chinese have and which gave (and still give) social and personal identity to Chinese individuals. Loosening this network of relations means, as is well known, diminishing one's 'social face' at the risk of 'vanishing'.,144

This idea is also reinforced by the contemporary use of terms 'tramp/hooligan', 'blind flow', 'peasant worker wave' and 'floating population', ${ }^{145}$ by urban locals fearing the 'disorderly' and 'chaotic' nature of migrants. ${ }^{146}$ Such terms are akin to the commonly encountered disdain some urbanites have for rural people, or what many term 'country bumpkins' and 'peasants'. ${ }^{147}$ The term, 客民 kemin is a traditional label describing someone who 'settles or lives in a strange place; someone who is a stranger', ${ }^{148}$ and a further term 客家人 Kejiaren, is the name given to a special group of Han Chinese with their own Chinese dialect (the Hakka), and literally translates as 'guest people'. The Hakka people once resided in central China but consecutive wars forced them on a series of waves of migration, leaving most Hakka descendants residing in parts of Fujian, Guangdong, Guangxi, Taiwan, Southeast Asia, and scattered all over the world. Due to their continuous waves of migrations, the Hakka have been described as the 'Jews of the Orient' and like the Jewish diaspora, the Hakka people have often borne the brunt of negative stereotyping of migrants in China and overseas.

However, it is perhaps unsurprising to find evidence that these traditional cultural norms are less a hindrance to the process of migration in contemporary China. For many people migration for employment reasons is now seen as a 'sign and avenue for

\footnotetext{
${ }^{144}$ Mara Caira, "The Concept of Migration and Clandestinity in the Chinese Culture," Social Science and Information 47. no.4 (2008), p.624.

145 流讯、盲流、民工潮、流动人口.

146 无序、乱; Mallee, "Migration, Hukou and Resistance in Reform China."

147 乡巴佬、乡下人 or 农民 (nongmin).

${ }^{148}$ Stephen C. Averill, "The Shed People and the Opening of the Yangzi Highlands," Modern China 9, no. 1 (1983), p.87.
} 
success', gaining positive connotations in the minds of the rural population especially. ${ }^{149}$ This can be illustrated through the shift in the importance of the influence of guanxi networks on migration and the labour market. ${ }^{150}$ Xianbi Huang argues that guanxi networks are still influential in the state sector in jobs that are highly desirable, that are soft-skilled or where job performance is hard to measure but that the “...influence of guanxi networks is ... limited, resisted or eliminated when large corporations, mostly in the non-state sector, adopt transparent and standardized procedures to screen and recruit the most qualified candidates." ${ }^{151}$ This is an encouraging trend but we must be careful not to negate the influence of migrant networks based on familiar and local relations, especially when discussing the lower end jobs that the vast majority of China's internal migrants engage in. What we can take from this is the beginning of a new trend in migration that is less determined by traditional cultural ties and more meritocratic and determined by employers' needs to find the most suitable workers for their business. It is also important to note that the role of cultural norms and informal institutions (the social and cultural 'rules') have also dissuaded the act of internal migration in China. It is important to acknowledge that these social and cultural norms, values and 'rules', whilst influential, are not absolute and recent trends suggest they are in many cases becoming supplanted by different values and norms as internal migration, the dislocation of tens of millions of people from their traditional way of life, becomes more common and viewed in the interests of China's vast population. For the vast majority of China's internal migrants, known as nongmingong, migration has increasingly become a way of life and a chance to improve their economic fortunes.

\footnotetext{
${ }^{149}$ Caira, "The Concept of Migration and Clandestinity in the Chinese Culture." p.627.

150 关系网 (guanxi wang): A person's network of relations.

${ }^{151}$ Huang, "Guanxi Networks and Job Searches in China's Emerging Labour Market: A Qualitative Investigation." p.467.
} 


\subsubsection{The Demographics of Contemporary Internal Migration}

"During the 1950s and 1960s life expectancy at birth substantially increased. The 1970s and early 1980s were marked by a sharp decline in fertility. The late 1980s and the 1990s may be characterized as a period of great migration. Today in every major Chinese city migrants are found in many occupations-as taxi drivers, construction workers, restaurant workers, and petty traders in free-market enterprises. Migrants are changing the face of urban China." ${ }^{152}$

Zai Liang's census and survey studies provide detailed empirical evidence of the rapid increase in internal migration from the early 1980s onwards distinguishing 'temporary' and permanent migrations. ${ }^{153}$ Permanent migrations involve the Public Security Bureau (PSB) officially transferring a migrant's permanent hukou to their place of destination. Various scholars also refer to these migrants as hukou or huji migrants. 'Temporary' migrations refer to migrations in which the migrant has stayed in the place of destination for more than six months but does not have local hukou status in the area they are living. Scholars also describe these migrants as 'non-hukou' migrants. This distinction is critical to understanding the importance of the huji institution and to avoiding the assumption that because of the increase in 'temporary/non-hukou' migration in China in recent years the huji institution is no longer an impediment to migration or settlement. Zai Liang also describes 'temporary' migrants using the Chinese term the 'floating population'. This term is a reference to the status of nongmin who migrate without changing their permanent hukou locality. Because they no longer live at their registered location and migrate to areas all over China, they have become known as the 'floating population'; a reference to their dubious political status and tendency to move spontaneously within China often in search of low-end/3D (dirty, dangerous and demeaning) contract work in both the state and private economy. The term nongmingong (or mingong) is also commonly used and refers to nongmin who

\footnotetext{
${ }^{152}$ Liang, "The Age of Migration in China." p.499.

153 Ibid, Liang and Ma, "China's Floating Population: New Evidence from the 2000 Census."
} 
migrate in search of work and residence outside of their permanent hukou locality and who fail to transfer their permanent hukou location. ${ }^{154}$

Liang and Ma's 2004 study of the 2000, 1995, 1990 and 1982 full and sample Chinese Population Censuses provides data on all citizens in China who have lived over six months outside the county of their permanent hukou location. ${ }^{155}$ Figure 5 illustrates the dramatic rise in census recordings of 'temporary/non-hukou/floating population/nongmingong' migrations over county borders from 1982 to the year 2000 .

Figure 5: Growth of the Inter-County Floating Population in China, 1982-2000

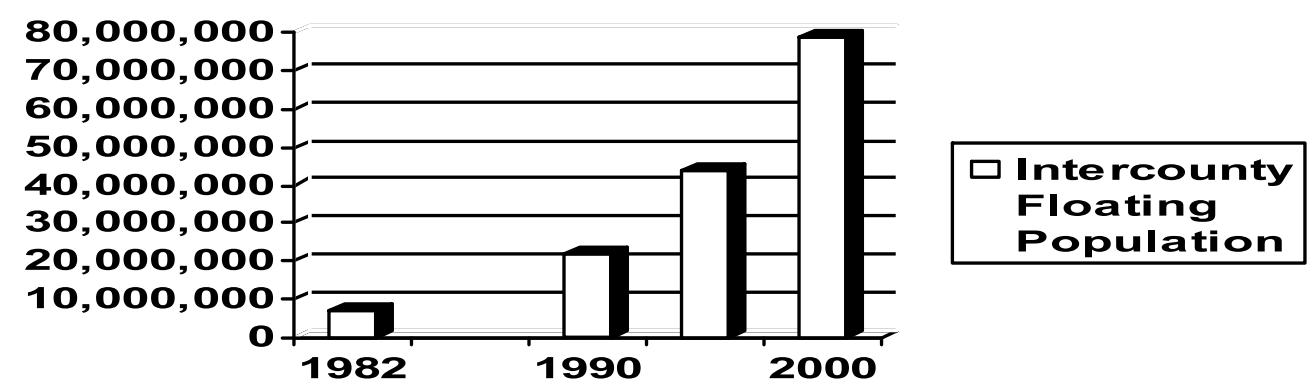

Source: Adapted from Liang and Ma (2004) p.471

Liang and Ma's 2004 study highlights the dramatic growth in internal migration captured by the census data. Goodkind and West (2002) provide a range of estimates and definitions of China's floating population and discuss the ambiguity surrounding the concept noting that in China the term is widely used in media and state addresses but there remains no official definition of the term. ${ }^{156}$ They also define the floating population as migrants' living away from their permanent hukou location (nonhukou/temporary migrants) and note that census studies in China have not maintained a

\footnotetext{
154 农民工/民工 - 'Rural Labourer'.

155 The county is a medium level political division in China The division of administrative areas in China is as follows: Provinces, Autonomous Regions and Municipalities; Prefectures (both regions and cities); Counties (regions, cities and districts under the jurisdiction of cities); Townships (regions, street communities and towns). As of 2006 there were 4085 counties in China, see: National Bureau of Statistics of China, China Statistical Yearbook 2007.

${ }^{156}$ Goodkind and West, "China's Floating Population: Definitions, Data and Recent Findings."
} 
standard definition with earlier censuses using a 12 month period to determine the floating population and latter censuses using a shorter 6 month period. Studies have also utilised different spatial levels of analysis, with some measuring moves across provinces, others moves across counties and others still defining a migrant as anyone living away from their permanent hukou location. Goodkind and West's summary of census and Ministry of Public Security data shows the different results forthcoming when criteria of the floating population are not standardised across all studies. Figure 6 shows estimates of China's floating population from two institutions in China, the State Statistical Bureau and the Ministry of Public Security.

Figure 6: Measures of China's 'floating population' (millions)

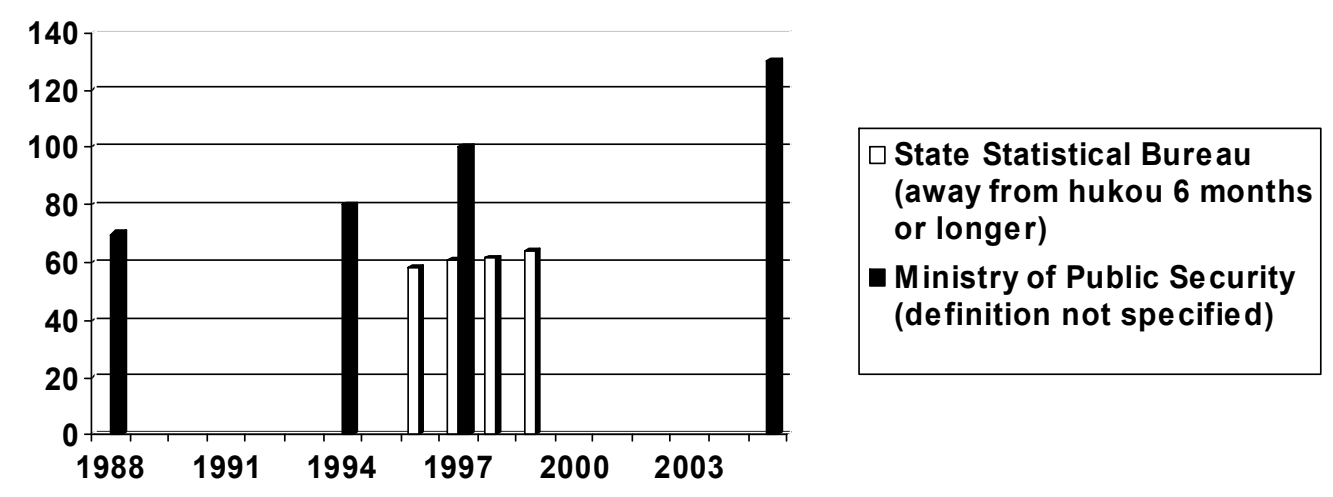

Source: Adapted from Goodkind and West (2002) ${ }^{157}$

Data from Liang and Ma (2004) and Goodkind and West (2002) show the size of the floating population (the amount of people living away from their permanent hukou location for six months or more) is steadily increasing. Liang and Ma's estimates show that since 1982 the intercounty floating population has increased over tenfold, growing from 7 million in 1982 to 79 million in 2000. The Ministry of Public Security estimates the number to have increased to an all time high of 130 million in 2005. Huang and Zhan (2005) quote government figures of 140 million in $2003 .{ }^{158}$ Amnesty International

\footnotetext{
${ }^{157}$ Data extracted from Table 1 of Ibid, p.2241.

${ }^{158}$ Ping Huang and Shaohua Zhan, "Internal Migration in China: Linking It to Development," in Regional Conference on Migration and Development in Asia (Lanzhou, China: People's Republic of China Ministry of Foreign Affairs, 2005).
} 
state similar figures and estimate the number of nongmingong will increase to 300 million by $2015 .{ }^{159}$ Chinese media and the response of government organs attest to their growing presence in urban areas.

\subsubsection{Nongmin Migrants: Discrimination, Abuse \& Exploitation?}

The vast majority of China's internal migrants are nongmin, migrating to urban centres but not receiving permanent urban hukou status in that location. The 2005 Regional Conference on Migration and Development in Asia, presented statistics from the Commission of Population and Family Planning and the Ministry of Agriculture showing that, "In 2003, the so-called floating population, i.e. people who are not permanently registered in their current place of residence, reached 140 million [of which] as many as 114 million rural labourers participated..."160 Studies that compare shimin and nongmin migrants show that general demographic characteristics differ markedly. Shimin migrants are the most affluent group of migrants in China, the most highly educated, the most likely to obtain permanent and well-paying employment and the most likely to be able to transfer their permanent hukou status from origin to destination. Nongmin migrants are the poorest, the least well educated and skilled, the least likely to obtain affluent employment and the least likely to obtain permanent hukou transfer through migration. It is this later group of migrants that most studies have focused on and which are also of primary interest in this study of formal institutional change in the huji system. Nongmin migrants are predominantly young in their late teens to early thirties, ${ }^{161}$ and migrate to earn a wage in the relatively affluent urban workforce.

\footnotetext{
${ }^{159}$ Amnesty International, "People's Republic of China: Internal Migrants: Discrimination and Abuse, the Human Cost of an Economic 'Miracle'," (New York: Amnesty International, 2007).

${ }^{160}$ Huang and Zhan, "Internal Migration in China: Linking It to Development."

${ }^{161}$ Liang and Ma, "China's Floating Population: New Evidence from the 2000 Census."
} 
The National Bureau of Statistics of China calculates the total number of China's floating population that migrate for 'work or business' reasons as $73 \%$ of the national group. ${ }^{162}$ The type of work nongmingong are commonly involved in differs for men and women but both are generally found in 3D work. Knight et al found that most migrants are located in service and construction industries. ${ }^{163}$ In a later study Wong et al found that, “...most migrant workers take up physically demanding jobs as manual labourers, textile and garment factory workers, toy factory workers and service workers." 164 Roberts argues that nongmingong are 'willing to do jobs that residents don't want' but that these 'willing workers' remain 'invisible residents' in China's urban areas. ${ }^{165}$ Nongmingong work in both state and private enterprises but there is some regional variation. A survey from 1999 showed that the state sector employed $76 \%$ of rural migrant workers in Beijing whereas in Shenzhen the state only employed $45 \%{ }^{166}$ Studies and Chinese news articles also suggest migrant workers are overrepresented in illegal exploitative work, such as gangs and prostitution rings. Zhao and Kipnis argue that most of these appraisals are 'blatantly biased' and that while nongmin are overrepresented in crime there is “...an overemphasis on crime prevention and constricting migration and a lack of emphasis on providing services." ${ }^{167}$ These studies suggest that nongmingong remain at the bottom of the socioeconomic heap where opportunities are limited and exploitation more common. This is the case for both male and female rural migrants.

\footnotetext{
${ }^{162}$ National Bureau of Statistics of China Department of Population and Employment 国家统计局人口就 业司. 《2005 中国人口》[2005 China Population]. 北京 [Beijing]: 中国统计出版社 [China Statistics Press], 2006, p.127.

${ }^{163}$ John Knight, Lina Song, and Huaibin Jia, "Chinese Rural Migrants in Urban Enterprises: Three Perspectives," The Journal of Development Studies 35, no. 3 (1999).

${ }^{164}$ Daniel Fu Keung Wong, Chang Ying Li, and He Xue Song, "Rural Migrant Workers in Urban China: Living a Marginalised Life," International Journal of Social Welfare, no. 16 (2007), p.34.

${ }^{165}$ Kenneth D. Roberts, "Rural Migrants in Urban China: Willing Workers, Invisible Residents," Asia Pacific Business Review 8, no. 4 (2002), p.143.

${ }^{166}$ Knight, Song, and Jia, "Chinese Rural Migrants in Urban Enterprises: Three Perspectives."

${ }^{167}$ Shukai Zhao and Andrew Kipnis, "Criminality and the Policing of Migrant Workers," The China Journal, no. 43 (2000), p.101.
} 
Rural male migrants often work long hours on construction sites or are involved in other low-paid menial tasks such as guard duty, garbage collection or labouring. Women work in electrical manufacturing and assembly, processing work and service work as nannies and maids or work in restaurants and hotels. As in most countries, Chinese female migrant workers are yet to receive pay parity with their male counterparts. Studies have shown that women are paid $10 \%$ less than men for the same work. ${ }^{168}$ “According to the 1990 China Population Census, migrant women account for $46 \%$ of intraprovincial migrants and $42 \%$ of interprovincial migrants in China. The most recent data from the 2000 Chinese census show that $52 \%$ of migrants are women." ${ }^{169}$ Female migrants are often young single workers (nicknamed dagongmei) ${ }^{170}$ but also include mothers that migrate with their family and have a higher tendency to remain at destination for longer periods of time. ${ }^{171}$ Pun Ngai's 2004 article explores and critiques the labour conditions migrant women toil under arguing aside from a lucky few they work under poor conditions in both local and transnational corporations. ${ }^{172}$ In an earlier study, Tamara Jacka (1998) covers the discrimination migrant women in China's urban areas bear and chronicles their story and their fight to be treated with dignity by urbanities. $^{173}$

Nongmingong on average have a lower level of education and work skills in comparison to shimin but relative to nongmin (who remain at their registered rural hukou location) their levels are higher. ${ }^{174}$ Even though migrants in China tend to be much younger than

\footnotetext{
${ }^{168}$ Knight, Song, and Jia, "Chinese Rural Migrants in Urban Enterprises: Three Perspectives."

169 Zai \& Yiu Por Chen Liang, "Migration and Gender in China: An Origin-Destination Linked Approach," Economic Development and Cultural Change 52 (2004), p.423.

170 打工妹 (a combination of 'part-time worker' and 'little sister' meaning a young female employee).

${ }^{171}$ Kenneth D. Roberts, "Female Labor Migrants to Shanghai: Temporary 'Floaters' or Potential Settlers?," The International Migration Review 36, no. 2 (2002).

${ }^{172}$ Pun Ngai, "Women Workers and Precarious Employment in Shenzhen Special Economic Zone, China," Gender and Development 12, no. 2 (2004).

${ }^{173}$ Tamara Jacka, "Working Sisters Answer Back: The Representation and Self-Representation of Women in China's Floating Population," China Information 13, no. 43 (1998).

${ }^{174}$ Delia Davin, Internal Migration in Contemporary China (London: MacMillan Press, 1999).
} 
the rest of the origin population their generally higher education levels supports the general assumption that education promotes migration. Studies also suggest that nongmingong are increasingly better educated and skilled. Their presence in urban areas competing for employment with local residents has raised the employment aspirations of local residents who have turned to adult and higher education in order to distinguish themselves from skilled and educated migrant workers who will work for less pay and under poorer conditions. ${ }^{175}$ Institutional barriers to nongmin education levels also exist (see next chapter).

The general pattern of nongmin migration is from rural to urban and from western/central provinces to coastal provinces. ${ }^{176}$ Nongmin migrations are generally correlated with relative incomes. Income in urban areas is far higher than in rural areas and this gap continues to grow, further perpetuating the economic motivation to migrate. ${ }^{177}$ Regional inequality is also growing with most of China's wealth accumulating in the more developed eastern provinces. This perpetuates the trend towards migrating to the east, as "...migrants (temporary migrants especially) are more likely to choose provinces with high levels of foreign capital investment as destinations." 178 Moreover, anticipated "...spillover effects have been insufficient to ameliorate regional inequality in China. This failure threatens Chinese social stability and increases the risk of political and social fragmentation and massive interregional migration." 179 Whilst it is not uncommon for nongmingong to migrate against this

\footnotetext{
${ }^{175}$ Kai-Ming Cheng, Xinhuo Jin, and Xiaobo Gu, "From Training to Education. Lifelong Learning in China," Comparative Education 35, no. 2 (1999).

${ }^{176}$ Lin, Wang, and Zhao, "Regional Inequality and Labor Transfers in China.", Liang, "Foreign Investment, Economic Growth, and Temporary Migration: The Case of Shenzhen Special Economic Zone, China."

${ }^{177}$ Yang, "Urban-Biased Policies and Rising Income Inequality in China."

${ }^{178}$ Liang and White, "Market Transition, Government Policies, and Interprovincial Migration in China: 1983-1988." p.334.

179 J.F. Brun, J.L. Combes, and M.F. Renard, "Are There Spillover Effects between Coastal and Noncoastal Regions in China?" China Economic Review 13 (2002), p.168.
} 
general trend, China's economic developmental model suggests that these two general patterns will continue for some time.

The plight of millions of nongmingong has been recognised by NGOs such as Amnesty International as a human rights problem that is rapidly exasperating. Amnesty estimates the number of nongmingong in urban areas will rise from a mere two million in the 1980s to an expected 300 million in 2015. NGOs note efforts made by the Chinese government but critique the implementation of these efforts and argue that far more needs to be done to provide public services and to ensure migrants' legal rights as Chinese citizens are upheld. Amnesty in particular argues this special social group is open to discrimination, abuse and exploitation from employers, city residents and even urban bureaucracies:

"Tens of millions of migrants are denied rights to adequate health care and housing, and are excluded from the wide array of state benefits available to permanent urban residents. They experience discrimination in the workplace, and are routinely exposed to some of the most exploitative conditions of work. Internal migrants' insecure legal status, social isolation, sense of cultural inferiority and relative lack of knowledge of their rights leaves them particularly vulnerable, enabling employers to deny their rights with impunity. The children of internal migrants do not have equal access to free, compulsory, education, and many of them have to be left behind in the countryside."180

Migrant concerns with these issues as well as the issuing of temporary hukou or processing hukou have at times turned to violent rioting and protest. Common complaints include corruption by government officials that charge extortionist fees, poor working conditions and the withholding of wages or failing to pay nongmingong in full. ${ }^{181}$ Complaints generally stem from a concern that, "the costs and the benefits of reform increasingly have been allocated not by impersonal market forces nor the

\footnotetext{
${ }^{180}$ Amnesty International, "People's Republic of China: Internal Migrants: Discrimination and Abuse, the Human Cost of an Economic 'Miracle'." p.2.

${ }^{181}$ See for a recent example: Chris Buckley, "Migrant Workers Protest and Riot for 3 Days in East China," Reuters(14.07.2008), www.reuters.com/.
} 
authority of the party but by corruption and favoritism." ${ }^{\prime 12}$ Some migrant workers will go to extraordinary lengths to have their protests heard by the central government. ${ }^{183}$ Drawing on two recent reports, the first from Amnesty International and another from the International Labour Organisation, critiques of the huji institution fall into the following categories: legal issues; class issues; work issues; health issues; and education issues.

Firstly, regarding the legality of the huji institution with respect to international legal standards and the right to equality, the International Covenant on Economic, Social and Cultural Rights (ICESCR), to which China is a state party, clearly states that the rights enunciated in the covenant will be exercised without discrimination of any kind. The huji institution fundamentally distinguishes between the rights of Chinese citizens based on the location of their permanent hukou and yet "social origin' is explicitly listed as an unlawful basis of discrimination". ${ }^{184}$ The rise of nongmingong in China's once protected urban areas has brought many challenges to China's urban institutions. Accommodating nongmin in urban areas within the existing institutional arrangements is a challenge the government has a governing, legal and moral duty to address, for failure to do so is clearly a breach of the right to equality enshrined in the PRC Constitution (see: 'Article 4: All nationalities in the People's Republic of China are equal'). ${ }^{185}$

Secondly, informal institutional arrangements also lead to economic, social and cultural

\footnotetext{
182 T. David Mason, "Modernization and Its Discontents Revisited: The Political Economy of Urban Unrest in the People's Republic of China," The Journal of Politics 56, no. 2 (1994), p. 400.

${ }^{183}$ In September 2005 a migrant worker is reported to have killed 4 people to get his unpaid wages, see: AsiaNews.it, "Migrant Worker Condemned to Death: He Killed to Get His Wages," (AsiaNews, 06.09.2005). In July 2006, a migrant worker set himself on fire in Tiananmen Square to protest unpaid wages, see: AsiaNews.it, "Migrant Worker Sets Himself Ablaze in Tiananmen Square," (AsiaNews, 21.07.2006).

${ }^{184}$ Amnesty International, "People's Republic of China: Internal Migrants: Discrimination and Abuse, the Human Cost of an Economic 'Miracle'." pp.3-4.

${ }^{185}$ Standing Committee of the National People's Congress, "Constitution of the People's Republic of China," (People's Daily Online, 1982). Viewed on 29/09/2008 at the website:

http://english.peopledaily.com.cn/constitution/constitution.html.
} 
class status accompanying hukou. Nongmingong often bear the social brunt of being looked down upon and of being exploited by urban residents. Urban residents not only receive state benefits that migrants do not, they also use their position of relative power to further exploit those trying to make it in the city. With only an estimated $40 \%$ of internal migrants having a temporary or permanent resident permit, ${ }^{186}$ their dubious legal status make this exploitation possible, but so does the informal workings of the huji system that has distinguished between urban and rural people, local and 'foreigner' ${ }^{187}$ for centuries. There is a psychological, class and socio-economic status associated with hukou status. Studies of illegal migrants and many legal migrants in countries such as the United States show that migrants often live in the poorest conditions, do the so-called 3D jobs (dirty, dangerous and demeaning), are relatively less educated and skilled than existing locals and bear the brunt of stereotyping and ethnic discrimination. ${ }^{188}$ In China, 'provinciality' and rural roots can be an insurmountable barrier to acceptance and equal treatment in the cities by local urbanites. This problem is institutionalised by the huji system which legitimises these informal prejudices by preventing migrants changing their birth status. ${ }^{189}$ Or as Wang Sujun, a guard at a district office in Beijing states:

"I've been disappointed here in Beijing. The people from the city hear immediately whether you're one of them or not. They have no respect for people from the provinces.

Thirdly, the working rights of nongmingong have been severely criticised over cases of denial of labour contracts; forced overtime; denial of holidays; the use of fines by

\footnotetext{
${ }^{186}$ Max Tunon, "Internal Labour Migration in China: Features and Responses," (Beijing: International Labour Organisation, 2006), p.7.

187 外地人 waidiren: this phrase means 'foreigner' in the sense of someone from a foreign place, not necessarily from a foreign country as is generally the meaning when foreigner is used in English. 外国人 waiguoren is used when specifically talking about people from a foreign country.

${ }^{188}$ See for example: Philip Kasinitz et al., "Becoming American/Becoming New Yorkers: The Second Generation in a Majority Minority City" (Migration Policy Institute, 2006).

${ }^{189}$ See: Fan, "The Elite, the Natives, and the Outsiders: Migration and Labor Market Segmentation in Urban China."

${ }^{190}$ Wang Sujun cited in: Floris-Jan van Luyn, A Floating City of Peasants (New York: The New Press, 2008), p.115.
} 
managers; unpaid wages; financial penalties and the obstruction of the right to leave employment; and grossly inadequate housing arrangements for workers. ${ }^{191}$

"Internal migrant workers, due to their insecure legal status, social isolation, their sense of cultural inferiority, and relative lack of knowledge concerning their rights, labour under some of the worst working conditions and experience some of the worst abuse in the work place. In factories with high concentrations of migrant workers one finds widespread denial of workers' rights to a fair wage, to safe working conditions, to organize and join labour unions of their choice, to freedom of movement, as well as to state-mandated workers' benefits." ${ }^{\prime 192}$

The exploitation of migrant workers is partially possible due to their relatively low level of education and work skills (relative to the urban population but higher than the rural population) but is also possible because of their institutionally defined hukou status:

"...in a climate of intense national and international competition, local governments can better attract investment by forfeiting workers rights and company's social security payments. In this 'race to the bottom', migrant work is typically limited to jobs that the urban population find too hard or demeaning. Discrimination plays a role in preventing migrant workers from obtaining certain types of employment: some urban authorities, particularly those struggling to re-employ laid-off staff from SOEs, maintain protectionist labour policies that safeguard the better jobs for permanent residents. "193

Fourthly, nongmingong are also shut out of health care because they, “...are typically not eligible for the new urban health insurance schemes being established in the cities, cannot afford the expensive new private insurance schemes ... and cannot pay out of pocket for health care that has sky-rocketed in cost in recent years." ${ }^{194}$ Whilst city residents have available a variety of welfare schemes and rural residents have a plot of land, there remains a policy gap in-between to provide social protection to rural labourers in towns and cities. The social welfare system excludes migrants in the following three areas: social insurance; healthcare; and education. For social insurance-including pension schemes, medical care, unemployment insurance, employment injury insurance and maternity leave-estimates range from $33 \%$ to $5 \%$

\footnotetext{
${ }^{191}$ Amnesty International, "People's Republic of China: Internal Migrants: Discrimination and Abuse, the Human Cost of an Economic 'Miracle'."

192 Ibid, p.7.

193 Tunon, "Internal Labour Migration in China: Features and Responses." p.10.

${ }^{194}$ Amnesty International, "People's Republic of China: Internal Migrants: Discrimination and Abuse, the Human Cost of an Economic 'Miracle'." p.15.
} 
participation by migrant workers. For healthcare, $80 \%$ of the rural population have no health insurance. ${ }^{195}$ Nongmingong largely remain outside of the state health policies that distribute information and programmes that have improved the health of China tremendously in recent decades.

Lastly, children of nongmingong also face further institutionalised exclusion by their inability to receive compulsory education in the areas their parents are working and residing without paying a hefty 'donation' to the state school (estimated at around $12,000 \mathrm{RMB}$ in Beijing). Over half of migrant children's parents cannot pay the 'donation' and therefore fail to enrol their children in a state school in the area they are residing. This leaves three options: have their children attend school in the location of their permanent hukou (separate the family); have them attend a 'migrant school' that is poorly resourced but a lot cheaper and subject to closure; ${ }^{196}$ or, avoid the education authorities. ${ }^{197}$ Moreover, all children must return to their permanent hukou location to sit national university entrance examinations. Depending on the location of the exam (as defined by the location of one's hukou) different scores on the exam are required to attend the best universities. ${ }^{198}$ Students that attend university outside of their hukou location must transfer their hukou status and upon graduation transfer it again, a situation described as akin to 'command economy conditions for student hukou management'. ${ }^{199}$ Even after graduating, students without local hukou still bear the brunt of discrimination when looking for work. It is common for employers and danwei (government employers including SOEs and companies with government contracts) to

\footnotetext{
195 Tunon, "Internal Labour Migration in China: Features and Responses."

196 See: Shanghai Daily, "Beijing to Aid Migrant Schools," (China.org.cn, 08.09.2006), Zhipeng Mao and Bo Ren, "Closure of Migrant Children Schools Exposes Education Deficiency," (Caijing.com.cn, 2004). ${ }^{197}$ See: China Daily, "Migrant Children Stay Bottom of Class," (People's Daily Online, 04.11.2004).

${ }^{198}$ Yan Wenhua 燕文华. "高考招生制度不平等拷问法律公平" [University Entrance Examination and Student Recruitment System Is Unequal and Questions the Impartiality of the Law]. 《牡丹江大学学 报》[Journal of Mudanjiang University ], 16, no. 4 (2007).

${ }^{199}$ Lantai World 兰台世界. "高校户籍档案管理模式初探" [Elementary Exploration of the University Huji Archive Management Model]. 《兰台世界》[Lantai World], no. 15 (2007).
} 
request that applicants have, amongst other things, a local hukou. ${ }^{200}$

And so, whilst in a developing nation the advent of increased internal migration, especially rural-to-urban migration is not uncommon as the society moves from premodern arrangements to modern arrangements characterised by a predominantly urban population, in China the huji institution acts to ensure these migrants remain 'outsiders' unable to gain permanent hukou status in their new area of residence and employment. Whilst discrimination and exploitation of new residents in urban areas has occurred in most developing nations the permanent 'outsider' status of China's internal migrants makes them more susceptible to this discrimination and unlike in other nations their children also inherit 'outsider' status. That migrations still occur in this institutional environment shows a desire on the part of nongmingong to contest the traditional premodern $^{201}$ arrangements of this institution. The act of migration is a form of migrant agency that contests China's state planning system, the top down migration strategies of the central planners and opens up a space for migrant endeavours. As the state has been slow to acknowledge and accommodate these new agents in society, migrants themselves have turned to self-organising.

\subsubsection{Migrant Agency: Networks and Self-Organising}

These migrations have led to some scholars arguing that rural migrants have created their own political space and are increasingly influencing policy decisions in urban areas; that they are exerting agency on the structure of the traditional huji system and the protectionist in-group nature of the urban bureaucracies and societies that they live and work within. Rural migrants, facilitated by the market, now spontaneously move to urban areas in search of employment and life opportunities for themselves and their

\footnotetext{
${ }^{200}$ Liu Zenghui 刘增辉. "就业歧视--大学生心中永远的痛" [Discrimination in Finding Employment: The Never-Ending Pain of University Students]. 《教育与职业》[Education and Vocation], no. 1 (2007). ${ }^{201}$ See: Chen and Wu, Will the Boat Sink the Water? The Struggle of Peasants in 21st-Century China.
} 
children even though they are confronted with an uncertain 'political status' and a lack of government services as well as social and class discrimination. Whilst the institutional arrangements are not set up to support internal migration, and actually operate in a way to deter movement and especially settlement, China's nongmingong have made internal migration possible through their own measures. As the common saying goes, for every policy from above, there is a countermeasure from below. ${ }^{202}$ They rely on guanxi and tongxiang relations to build their networks and self-organise in the space not filled by the state and urban bureaucracies. By doing this they exercise a form of agency that contests formal institutional arrangements and pressures the authorities to adapt and take into account the new institutional environment.

Hein Mallee's 2000 article, 'Migration, Hukou and Resistance in Reform China' emphasizes the 'role of millions of migrants in bringing about change' showing the complexity of the relation between institutional reform and social change and pointing out the important role that migrants have in 'shaping outcomes'. "More often than not, local authorities could barely stay ahead of developments and reacted relatively passively by adjusting the regulations affecting migration." 203 The 'illegality' of much rural-to-urban migration or at best the grey area of rights and access to urban goods and services, has led to informal self-organisation and resistance to state controls and management. ${ }^{204}$ Migrants are now a common element of urban life and their presence requires the state and municipal bureaucracies to take them into consideration. Belated government responses, such as now including nongmingong representatives at the 2008 National People's Congress further support this point. ${ }^{205}$

\footnotetext{
202 上有政策、下有对策 Cited in : Mallee, "Migration, Hukou and Resistance in Reform China." 203 Ibid, p.83 \& p.99.

${ }^{204}$ Ibid.

${ }^{205}$ Xinhua News Agency 新华社. 《商国是 谈履职一一记三位农民工代表的首次会面》[Discussing Important Matters of the State ... Recording the First Meeting of Three Nongmingong Representatives]. 新华网 [Xinhua Online], 04.03.2008. http://news.xinhuanet.com/photo/2008-03/04/content_7714576.htm.
} 
Forms of self-organising are outlined in a recent Nautilus Institute online policy forum document that looks at the current plight of China's rural migrant workers in the cities. The authors, Jia and Zhao (2008) distinguish between the civil society groups that are self-organising, including the Little Birds and the Panyu Migrant Workers Service Centre, and the government supported organisations, such as the Migrant Worker's House or the Nippon Village. They state that, "Self-organization is a core tenet of Chinese civil society. Thus civil society organizations play a prominent role in promoting the self-government of migrant workers ... The members of these organizations identify personally with migrant workers and provide services such as information, legal aid, cultural and sports activities, and advocacy for migrant rights."206 Both types of civil society groups have the job of promoting the self-management and protecting the rights of migrant workers. In recent times migrant self-organising and advocacy has begun to have success at promoting the rights of migrant workers and these groups are even starting to hold press conferences and utilise the media to advocate for migrant's rights. This is a positive sign as in the past all too often migrant workers were forced to take to the streets as their voices went unheard and their rights as Chinese residents went unprotected. Other studies have also noted the self-organising nature of migrant communities in urban areas.

Solinger (1999) looks at the role of 'migrant agency' through peasant (nongmin) clustering, self-organising and their general presence in the once protected urban areas. Solinger argues these rural migrants are 'contesting citizenship'; are growing more vocal; are becoming more aware of their legal and constitutional rights; are challenging the 'urban goods regime'; and are increasingly influencing the policy considerations of

\footnotetext{
${ }^{206}$ Xijin Jia and Yusi Zhao, "China Civil Society Report: Chinese Civil Society Impacts on Urban Migration," (Nautilus Institute for Security and Sustainable Development, 09.12.2008).
} 
government elites. ${ }^{207}$ Migrant agency represents a powerful force for structural change in China and sees the act of rural to urban migration as an active rather than passive force exerting pressure on existing urban-centric policies and institutions that fail to provide for China's newest urbanities. However, as Solinger and others have noted, at present the $h u j i$ “...system still denies migrant workers their fundamental right as a Chinese citizen to be treated equally." ${ }^{208}$ This suggests that migrant agency will continue to be a force for change swelling from the grassroots of Chinese migrant society for some time to come.

A related focus is the work of scholars who analyze China's migration in terms of the self-organisation of informal networks that bind migrants together. "Migrant networks are sets of interpersonal ties that connect migrants, and nonmigrants in origin and destination areas through ties of kinship, friendship, and shared community origin." ${ }^{209}$ Migration between relatively affluent receiving areas and poorer sending areas that cross state borders tends to be circular and based on kinship networks. In China networks are commonly organised along tongxiang relations, ${ }^{210}$ and self-organising migrant communities in urban areas are 'villages' in the city. ${ }^{211}$ "Family and fellowvillagers play a role in shaping, directing and perpetuating migration flows. This is why we find settlement of people from the same origin in a destination area and a tendency to rebuild community ties around pioneers. The routes of population flows are ... the same over decades and centuries ... [and] 'illegal' individuals can survive in local rebuilt 'village communities' inside larger Chinese cities.",212

\footnotetext{
${ }^{207}$ Solinger, Contesting Citizenship in Urban China: Peasant Migrants, the State, and the Logic of the Market.

208 Jiajiao Rong, "Hukou 'an Obstacle to Market Economy'," China Daily, 05-21 2007.

${ }^{209}$ Massey et al., "Theories of International Migration: A Review and Appraisal."

210 同乡 People from the 'same village', meaning people that come from the same village, town, province or region of China that share economic and cultural similarities such as dialect.

${ }^{211}$ For example 浙江村 Zhejiangcun Zhejiang Village (located in Beijing City).

212 Caira, "The Concept of Migration and Clandestinity in the Chinese Culture." p.627.
} 
Returning to the analogy of international migration patterns, the China-Mexico/US comparative migration studies of Roberts (1997 and 2007) argues that as in the case of Mexican migration to the US, 'migrant networks will mature' with three important implications: firstly, the magnitude of migration will grow, secondly, regional specificity of migrant flows between origin and destination will likely intensify, and finally, the process of settlement will likely intensify and migrants will likely cluster in specific neighbourhoods in and around the city. Case studies of Chinese internal migration support these assertions. ${ }^{213}$ Migrant network theory, the comparisons of Roberts and the accompanying case studies strongly suggest that migrant organising, migrant networks and above all migrant agency will continue to be a powerful political force. Exactly how this migrant agency interacts with formal structures (particularly the huji institution) remains an area of open debate and is a focus of the current research.

What is clear is that the fundamental functions of the huji institution remain. In the eyes of the government and party policymakers the huji institution limits pressure on urban bureaucracies and infrastructure and helps maintain social stability. ${ }^{214}$ A growing chorus of scholars, lawyers and rural and urban migrants are calling for hukou reform, in particular the abolishment of hukou dualism. ${ }^{215}$ This brief look at the criticisms and response of China's internal migrants to the traditional urban/national governing systems is designed to underlie some of the pressure central and local governments are

\footnotetext{
${ }^{213}$ Yaohui Zhao, "The Role of Migrant Networks in Labor Migration: The Case of China," Contemporary Economic Policy 21, no. 4 (2003), Biao Xiang, "Zhejiang Village in Beijing: Creating a Visible NonState Space through Migration and Marketized Networks," in Internal and International Migration: Chinese Perspectives, ed. Frank N. Pieke and Hein Mallee (Cornwall: Curzon Press, 1999), Transcending Boundaries : Zhejiangcun : The Story of a Migrant Village in Beijing, trans. Jim Weldon (Boston: Brill, 2005).

${ }^{214}$ Wei Liqun 魏礼群, and Han Changfu 韩长赋, eds. 《中国农民工调研报告/国务院研究室课题组》 [China's Nongmingong Research Report/Discussion Group of the Research Department of the State Council]. 北京 [Beijing]: 中国言实出版社 [China Yanshi Press], 2006.

${ }^{215}$ See for example: Su Zhixia 苏志霞, and Wang Wenlu 王文录. "论户籍制度的功能定位" [A Discussion of the Function of the Hukou System ]. 《河北师范大学学报/哲学社会科学版》 [Journal of Hebei Normal University/Philosophy and Social Sciences Edition ] 30, no. 2 (2007).
} 
experiencing in order to help explain the adaptations of the system and to uncover the dynamic relationship between economic development, migration and huji adaptation.

To sum up, the migration patterns of nongmin are predominantly rural to urban; ${ }^{216}$ within a province; ${ }^{217}$ from western/central China to eastern China; ${ }^{218}$ and in many cases these migrations are circular or chain migrations. ${ }^{219}$ The floating population is steadily increasing, growing from around 20 million in the early 1980 s to over 130 million in 2005, driven primarily but not exclusively by nongmin in search of work in urban areas and especially in China's booming eastern coast. Nongmingong are generally relegated to low socioeconomic status in the cities and do the work that urban residents will not; organising along tongxiang relations and resisting state regulations. Relative to their local brethren they are disproportionately young and better educated but relative to their urban competitors they remain less educated, less skilled and far less affluent. Critiques of the huji institution point to discriminatory practices and poor working conditions as well as a fundamental issue with the way the institution excludes nongmin from full participation in city life. Studies argue that rural-to-urban migration exists within migrant networks and that nongmin create 'villages' in urban areas as well as postulating that migrant agency is increasingly influencing the policy considerations and institutional arrangements of the urban centres.

\subsection{Conclusion}

This chapter has shown that studies link the 'age of migration' with China's economic development and the transitional nature of the economy. The changes that have occurred since the late 1970s have involved liberalization of the national economy and

\footnotetext{
${ }^{216}$ Solinger, Contesting Citizenship in Urban China: Peasant Migrants, the State, and the Logic of the Market.

${ }^{217}$ Davin, Internal Migration in Contemporary China.

${ }^{218}$ Liang and Ma, "China's Floating Population: New Evidence from the 2000 Census."

${ }^{219}$ Roberts, "China's 'Tidal Wave' of Migrant Labor: What Can We Learn from Mexican Undocumented Migration to the United States?"
} 
the unshackling of China's rural labour force. This has led to greater levels of internal migration, concerns for the rights of China's newest urban labourers and some evidence of self-organising. Migrant agency is used by some studies to suggest that this selforganising is having an influence on the unfolding of policy in urban areas. This suggests consideration of China's huji system is critical to understanding China's economic and political transition over the reform era. How this institution has adapted to the challenge of unregistered 'rural residents' in urban China remains central to understanding economic development, internal migration patterns and the process of formal institutional change. The next chapter takes a close look at the formal arrangements of the huji system, its institutional objectives, why it remains important and the institutional changes it has gone through over the last three decades. 


\section{The Huji Institution}

"...in the Chinese city, state institutions not only shape migration processes and labor market segmentation but are also engendering a new social order marked by institution-backed socioeconomic stratifications. The Chinese urban labor market is complex. Its complexity is due in no small part to the persistent role of the state in monitoring the way in which plan and market coexist. It is this institutional factor that undermines the applicability of existing theories. The neoclassical and behavioral approaches do not specifically address the role of institutions. The labor market segmentation theory offers a useful guide, but it needs to expand to incorporate the role of the state and state institutions. An institutional perspective is especially necessary in socialist and transitional economies in which segmentation is very much defined by institutional affiliations and status. ${ }^{, 220}$

The role of the state in migration studies remains a relatively new field of research in political science, particularly in studies of migrations that do not cross international borders. Skocpol's (1985) appeal to 'bring the state back in' to explanations of economic change is echoed by Hollifield's (2000) call to 'bring the state back in' to the analysis of international migration. ${ }^{221}$ In China nation state borders do not exist but when dealing with a population of over 1.3 billion it is not surprising to find an important role for the state in the management of migration and settlement across regions, provinces and rural/urban areas that dwarf the population size of most nationstates. This role goes further than 'creating' the politico-economic institutions that facilitate migration, ${ }^{222}$ or rural officials facilitating migration by arranging work for local residents in urban SOEs, ${ }^{223}$ state laws and urban governments oversee the migration and settlement of residents in every corner of China.

Studies show the institutional arrangements of the Chinese state, in particular the huji institution, actively shape and constrain the migration patterns of contemporary China: Solinger (1999) highlights the enduring role of the 'urban goods regime', the huji

\footnotetext{
${ }^{220}$ Fan, "The Elite, the Natives, and the Outsiders: Migration and Labor Market Segmentation in Urban China." p.120.

${ }^{221}$ Hollifield, "The Politics of International Migration: How Can We 'Bring the State Back in'?"

${ }^{222} \mathrm{Hu}$, Wang, and Zou, "Political Economy of the Floating Chinese Population."

${ }^{223}$ Lei Guang, "The State Connection in China's Rural-Urban Migration," International Migration Review 39 , no. 2 (2005).
} 
institution and the varying citizenship rights of residents in urban China; ${ }^{224} \mathrm{Lu}$ Yilong (2003) analyzes the huji system stressing its function maintaining political and social order, limiting urbanisation pressure and aiding the bureaucracy; ${ }^{225}$ Fei-ling Wang (2005) identifies the importance of the huji institution to China's changing patterns of socio-economic division and exclusion; ${ }^{226}$ and Fan $(2002,2008)$ analyzes the role of the state in migration patterns as well as the socioeconomic and regional barriers to urban citizenship and opportunity. ${ }^{227}$ Countless other studies show the importance of huji and other institutions to China's domestic migration patterns but there remains a need for further studies that look to explain changes in the huji system itself over the reform period.

This chapter focuses on how China's huji system shapes the behaviour of actors and explores the question how and why these institutional arrangements have both adapted and endured during China's transitional era. In order to create a baseline for the period of study (1978 - 2007), an overview of the history of Chinese migration and the functioning of the huji institution pre-'reform and opening' is outlined. Many readers may be surprised to learn that this requires one to venture back as far as the very origins of political life in China and that China's history of internal migration controls show startling continuity and stability over early and late parts of the premodern era, the Republican era, and the pre-reform era (1949-1978). Then the function of the huji institution and the state's role in managing domestic migration over the period of study (1978 - 2007) is discussed before looking at its enduring importance by distinguishing six categories of hukou status as a determinant of life opportunity and finally

\footnotetext{
${ }^{224}$ Solinger, Contesting Citizenship in Urban China: Peasant Migrants, the State, and the Logic of the Market.

${ }^{225}$ Lu Yilong 陆益龙. 《户籍制度: 控制与社会差别》[The Huji System: Control and Social Disparity].

${ }^{226}$ Wang, Organizing through Division and Exclusion: China's Hukou System.

${ }^{227}$ C. Cindy Fan, China on the Move: Migration, the State, and the Household, Routledge Studies in Human Geography (Oxon: Routledge, 2008), p.2.
} 
summarising reform era institutional changes and asking how and why these changes came about. As shown in this section many questions remain. These will be addressed in the final chapter which constructs a model of institutional change.

\subsection{History of Internal Migration Controls}

"The origins of the hukou system lie embedded in the baojia system of population registration and mutual surveillance perfected over a millennia. But its antecedents also lie in the $20^{\text {th }}$ century techniques of social control that were perfected in areas under Kuomintang and Japanese rule, and in the Communist-led revolutionary base areas. Equally important is the direct influence of the Soviet passbook system [propiska] and the role of Soviet advisers in creating a social order that could be mobilized in the service of socialist developmental priorities. $^{2228}$

The huji institution and its predecessor in dynastic times, the baojia system, ${ }^{229}$ have a high degree of 'historical legitimacy'. ${ }^{230}$ The importance of this to the functioning of contemporary China's huji institution becomes clear when we consider that "the human tendency to be path-dependent and the political logic of institutional inertia play a great part in legitimizing and enforcing an institutional exclusion ... older institutions tend to be internalised over time and thus form powerful forces of culture and tradition. ... Legal norms ... can often be built on the sheer power of tradition alone." ${ }^{231}$ To understand the path dependency and institutional inertia of the current huji institution and the significance of changes to this institution in contemporary times, this section will briefly outline the dynastic and republican period history of internal migration and the functioning of the huji and baojia institutions before moving on to a closer discussion of the adaptation of the huji institution for the 'purpose of restoring stability and implementing the socialist command economy ${ }^{232}$ in the early communist period (1949-1978). It is hoped this will provide the necessary understanding of the integral

\footnotetext{
${ }^{228}$ Tiejun Cheng and Mark Seldon, "The Origins and Social Consequences of China's Hukou System," The China Quarterly, no. 139 (1994), p.645.

229 保甲制度 Mutual Responsibility System.

${ }^{230}$ Wang, Organizing through Division and Exclusion: China's Hukou System.

${ }^{231}$ Ibid, p.32.

${ }^{232} \mathrm{Lu}$ Yilong 陆益龙. "1949年后的中国户籍制度: 结构与变迁" [Structure and Transition: The Household Registration System in China after 1949]. 《北京大学学报（哲学社会科学版）》[Journal of Peking University (Humanities and Social Sciences)] 39, no. 2 (2002).
} 
function this institution has played in all major Chinese governments allowing a closer examination of the institution in latter sections that cover the period of study 1978-2007.

\subsubsection{Xiangsui, Baojia \& Huji Institutions (pre-1911)}

The most thorough historical overview of China's institutionalised migratory controls in English comes from Fei-ling Wang's 2005 book, Organizing Through Division and Exclusion: China's Hukou System. ${ }^{233}$ Wang outlines in detail the development of the huji system through the early xiangsui and baojia systems, showing that the precursors of today's huji institution arose very early in China's history and were utilised for many of the same purposes it is used today. ${ }^{234}$ Wang argues that there was a systematic development of "...community-oriented, regionally based organization of families and clans for purposes of taxation and social control..." that begun as early as the Xia Dynasty $\left(21^{\text {st }}-16^{\text {th }}\right.$ century BC) with a population census and household registration and continued during the Shang Dynasty $\left(16^{\text {th }}-11^{\text {th }}\right.$ century BC) with a record of households. ${ }^{235}$ Jiang Lihua (2002) makes a similar argument, "The huji system consists chiefly of two things: one is a registration system and the other is a management system. According to oracle bone records [甲骨文记载], the Shang Dynasty had already put into force a population registration system with 'registered people' and 'registered groups' as well as a register of the temporary recruitment of soldiers. ${ }^{236}$ Following the Shang Dynasty, the ruling elites of the Western Zhou Dynasty $\left(11^{\text {th }}-8^{\text {th }}\right.$ century BC) further developed 'primitive forms of huji-like institutions', known as the xiangsui

\footnotetext{
${ }^{233}$ For Chinese sources see: chapter 2 of Lu Yi-long 陆益龙. 《户籍制度：控制与社会差别》[The Huji System: Control and Social Disparity]; pp.1-10 of Tian Bingxin 田炳新. 《中国第一证件: 中国户 籍制度调查手稿》[China's First Credential: China's Huji System Research Manuscript].; chapter 2 of Lu Yi-long 陆益龙. 《超越户口：解读中国户籍制度》[Transcending Hukou: Making Sense of China's Huji System]. 北京 [Beijing]: 中国社会科学出版社 [China Social Sciences Press], 2004.; Wang 王, Weihai 威海. 《中国户籍制度：历史与政治的分析》[China's Huji System: A Historical and Political Analysis].上海 [Shanghai]: 上海文化出版社 [Shanghai Culture Publishing House], 2006.

${ }^{234}$ Wang, Organizing through Division and Exclusion: China's Hukou System.

${ }^{235}$ Ibid, p.33.

${ }^{236}$ Jiang Lihua 江立华. "我国户籍制度的历史考察" [China's Huji System: An Historical Review]. 《人 口世界》[Population World], 2002.
} 
system. ${ }^{237}$ Then in the late Spring and Autumn period $(770-476 \mathrm{BC})$ some states, such as Qi, utilised a precursor to the full baojia system to register the population according to where they live and to block internal migration. ${ }^{238}$

However, not until the Qin (221 - 226 BC) and Han (206 BC - 220 AD) dynasties did the huji system solidify into the formal political and informal social/cultural institution that has been such an influential tool for governance in all of China's following dynasties and through into both the republican and communist eras. Lord Shang Yang, a prominent Legalist ${ }^{239}$ of the Qin court introduced the baojia system during the Warring States period (475 - $221 \mathrm{BC})$ to 'organise families into units collectively responsible for their activities to the state' and to expand the taxation base and control of society. ${ }^{240}$ After unifying China, the Qin dynasty $(221$ - 206 BC) widely imposed this system with harsh penalties for fugitives and drifters not adhering to the strict registration and controls on migration. The Qin Dynasty was soon replaced by the Han Dynasty (206 $\mathrm{BC}-220 \mathrm{AD})$ which further institutionalised this system by keeping the taxation and conscription function, adding hukou officials and issuing identification permits for travellers. Those lacking permits were imprisoned.

According to Wang, it is this Qin/Han system that with slight variations over each

\footnotetext{
${ }^{237}$ Wang, Organizing through Division and Exclusion: China's Hukou System. pp. 35-36. 238 Ibid.

239 法家 Legalism was the first philosophy to be used as a government doctrine in China with the establishment of the Qin Dynasty $(221$ - 206 BC) after the Kingdom of Qin were victorious in the Warring States period $(425-221 \mathrm{BC})$. This philosophy proposes that people are essentially selfish and the role of the state is therefore to ensure that people are made 'good' (in the sense of utilitarianism) through 'rule by (strict) law' and severe punishment. Though largely discredited and replaced by Confucianism after rebellions led to the fall of the Qin Dynasty after only 15 years in power and the establishment of the Han Dynasty, some scholars argue that the influence of Legalism continued through Confucianism and imperial rule (儒表法裹 - Confucian surface, Legalist inner) and continues in today's unitary one-party state. See: Chih-yu Shih, "National Role Conception as Foreign Policy Motivation: The Psychocultural Bases of Chinese Diplomacy," Political Psychology 9, no. 4 (1988), Kidder Smith, "Sima Tan and the Invention of Daoism, "Legalism," "Et Cetera"," The Journal of Asian Studies 62, no. 1 (2003), Edgar Kiser and Yong Cai, "War and Bureaucratization in Qin China: Exploring an Anomalous Case," American Sociological Review 68, no. 4 (2003).

${ }^{240}$ Wang, Organizing through Division and Exclusion: China's Hukou System.
} 
dynasty has remained the core foundation of China's huji institution. These variations include: replacing individual tax with household tax; varying differences in accuracy of records and enforcement of 'vagrancy' (explaining the 'countless reports of floaters, migrants and unrecorded persons who appear to have enjoyed a great degree of internal mobility' such as the Hakka); re-allocating hukou based on place of residence not place of birth after huge waves of migrations due to war or invasion; further incorporating the huji system into the overall imperial political structure during the Sui $(581-618)$ and Tang (618 - 907) dynasties; creating more detailed records; introducing strict protection of hukou data (state secrets) during the Song Dynasty (960 - 1279); introducing the issuing of hukou booklets for households and the keeping of records by both local and central government (hujizhidu) $)^{241}$ during the Ming Dynasty $(1368-1644)$; and the categorisation and treatment of different types of people. ${ }^{242}$ Furthermore, "By 1772, the Qing government stopped registering its people for taxation purposes. The millenniumold hukou system lost its tax function but continued in the form of a baojia system and became mainly a data-collection and social control institution."243

The baojia function of the huji system is the collective and mutual responsibility of households. "All families in the same bao shared a collective responsibility called lianzhuo - all were to be punishable alike if anyone was found violating the law or migrating illegally." ${ }^{244}$ It is this function of the huji institution that became an effective means of both controlling the communist insurrection in republican times and a means of social control during early communist governance, which included the use of the 'reeducation through labour system, 245 and millions of urban youth being 'sent down to the

\footnotetext{
241 户籍制度.

${ }^{242}$ Wang, Organizing through Division and Exclusion: China's Hukou System.

243 Ibid, p.39.

${ }^{244}$ Ibid. p.41; 连坐: (lianzuo) to implicate others related to the one charged or found guilty.

245 劳动教养制度.
} 
countryside $^{, 246}$ after the Cultural Revolution; both facilitated through a change of hukou status. During the late Qing period just prior to the fall of China's last traditional emperor, the Qing government legislated to install hukou laws. ${ }^{247}$ These laws were adopted in the republican period which at times and in places (for example Beijing) operated more like the dynastic governing system than a modern state. For over two millennia the centralised state utilised the huji system to manage the population, maintain social stability and restrict the movement of Chinese people. In 1911 the ageold Confucian governance fell to forces of modernisation and reform. However, as the following section will show, the huji system, the most fundamental of the dynastic governing institutions, did not fall with the imperial system.

\subsubsection{Republican Huji Institution (1911-49)}

The period between the fall of the Qing Dynasty (1911) and the establishment of the People's Republic of China (1949) is one of modernisation, division, warlordism, foreign invasion and civil war. The period of expansion experienced during the Qing Dynasty was undercut by wars and concessions to foreign powers (particularly Britain, France, Russia and Japan) that eventually contributed to the overthrow of the Qing Dynasty in 1911. However, after the fall of the Qing Dynasty, China continued to struggle with modernisation and fell into decades of internal upheaval and in-fighting. Throughout this period the huji institution continued to be used by the Republican Government, warlords and the communist insurrection alike, testament to the strength of the system and the fundamental nature of it to governance in China.

The 1911 huji law (Hujifa $)^{248}$ had for the first time codified in modern legal terms the role of the huji institution in China. This included, in principle, the right to freedom of

\footnotetext{
246 下乡.

${ }^{247}$ Lu Yilong 陆益龙. 《户籍制度: 控制与社会差别》[The Huji System: Control and Social Disparity]. 248 户籍法; Ibid.
} 
migration but also stipulated mandatory registration and centralised administration. ${ }^{249}$ According to Lu Yilong the Republican Government had two main purposes for the huji law they adopted from the late Qing government and the huji laws they latter promulgated. They were: "firstly, to investigate and shut down the communists; and secondly to press-gang able bodied men and to impose taxes to service the wars." 250 This period of history saw the Republican Government fighting first to reunify China after the fall of the Qing Dynasty and the rise of warlordism (the Northern Expedition), secondly to fight off the Japanese undeclared war that begun in the 1930s and concurrently to put down the communist insurrection which they eventually failed to do leading to their retreat to Taiwan. The huji laws they promulgated include: revision of the 1911 Hujifa in 1931 and 1946; the Interim Procedures for Investigating Hukou in $1929 ;^{251}$ the Baojia Regulations in $1937 ;^{252}$ the Hukou Census Law in $1947 ;^{253}$ and the Citizenship Identity Card System in $1946 .^{254}$

These laws, regulations and investigations were used to increase the baojia (mutual responsibility) function of the huji institution, centralise governance of the system, increase control over common people, increase the Republican Government's area of governance, control the 'floating population', control agricultural production (mainly for the military), and finally to strengthen governance and restore stability and order. ${ }^{255}$ During this period it is also important to note that communist forces also utilised the existing huji institutions as did the Japanese occupying forces. ${ }^{256}$ All governments in China, from the early competing kingdoms and fiefdoms to the great dynasties and

\footnotetext{
${ }^{249}$ Wang, Organizing through Division and Exclusion: China's Hukou System.

${ }^{250} \mathrm{Lu}$ Yilong 陆益龙. 《户籍制度: 控制与社会差别》[The Huji System: Control and Social Disparity]. 251 清查户口暂行办法.

252 保甲条例.

253 户口普查法.

254 国民身份证制度.

${ }^{255} \mathrm{Lu}$ Yilong 陆益龙. 《户籍制度: 控制与社会差别》[The Huji System: Control and Social Disparity].

${ }^{256}$ Cheng and Seldon, "The Origins and Social Consequences of China's Hukou System."
} 
centralised republican states, have used some form of the huji institution and its basic function of social control and implementing government objectives. As Wang notes, this shows that there is a high degree of historical legitimacy for the system, a point that is fundamental to understanding the path dependency and formal and informal institutional acceptance of the system historically and in contemporary times. ${ }^{257}$

\subsubsection{Communist Huji Institution 1949-78}

The legacy of the huji system continued through into the early communist era but also differed in certain fundamental ways as it was adapted to the new priorities of the newly formed socialist state. The core functions remained or were strengthened (census; maintain social stability; managing and restricting urbanisation) and the new priorities of allocating state resources, managing the command economy and maintaining strict social control, came to the fore. The baseline for the current huji institution is often taken as the 1958 law that cemented the division of town and country and clearly regulated the role of the Ministry of Public Security (MPS) in administering and regulating the movement and residence of citizens in China. Before this fundamental law, a series of proclamations and regulations appeared. In 1950 the Chinese state was ravaged from decades of war and human displacement and regulated to establish order and restrict migration to urban areas. In 1953 the government further registered the population and established regulations around the purchasing and supply of foodstuffs. In 1954, rural areas underwent registration procedures and strict regulations regarding the transfer of hukou were implemented. Further procedures and regulations further entrenched the division of urban and rural areas and solidified the administration and government supply of foodstuffs, oils and ration cards in 1955 and 1956. These regulations were brought together and implemented in the 1958 law: the People's

${ }^{257}$ Wang, Organizing through Division and Exclusion: China's Hukou System. 
Republic of China Hukou Registration Regulation. ${ }^{258}$ Table 2 from Lu Yilong shows the

list of proclamations and regulations that led to the 1958 hukou law.

Table 2: Fermentation and Formation of the Huji Institution 1949-1957

\begin{tabular}{|c|c|c|}
\hline Year & Legal Regulation & Contents \\
\hline \multirow{2}{*}{1950} & $\begin{array}{c}\text { Interim Procedures Concerning Special } \\
\text { Population Administration }\end{array}$ & Special population administration \\
\hline & $\begin{array}{c}\text { Provisional Regulations of City Hukou } \\
\text { Administration }\end{array}$ & $\begin{array}{l}\text { Administration of registration of the } \\
\text { permanent city population }\end{array}$ \\
\hline \multirow[b]{2}{*}{1953} & $\begin{array}{c}\text { National Population Survey Registration } \\
\text { Procedures }\end{array}$ & $\begin{array}{l}\text { Permanent population survey and } \\
\text { registration }\end{array}$ \\
\hline & $\begin{array}{c}\text { Resolution of the Central Committee of the } \\
\text { Communist Party of China Concerning the } \\
\text { Controlled Procurement and Distribution of } \\
\text { Foodstuffs }\end{array}$ & $\begin{array}{l}\text { Regulated the scope of purchasing and } \\
\text { supply of foodstuffs }\end{array}$ \\
\hline \multirow[t]{2}{*}{1954} & $\begin{array}{c}\text { Joint Announcement by the Ministry of Internal } \\
\text { Affairs, Ministry of Public Security and the } \\
\text { National Statistic Bureau }\end{array}$ & $\begin{array}{l}\text { Universal establishment of the rural } \\
\text { hukou registration system }\end{array}$ \\
\hline & $\begin{array}{c}\text { Establishment of the Regular Hukou } \\
\text { Registration System }\end{array}$ & $\begin{array}{l}\text { Administration and registration of } \\
\text { population and hukou changes }\end{array}$ \\
\hline \multirow[t]{2}{*}{1955} & $\begin{array}{c}\text { Interim Procedures [regarding] the Fixed } \\
\text { Supply of Town Foodstuffs }\end{array}$ & $\begin{array}{l}\text { Administration of the supply of } \\
\text { foodstuffs, ration cards and certificates for } \\
\text { transferring foodstuffs and oils }\end{array}$ \\
\hline & $\begin{array}{c}\text { Standard Regulations Regarding the Division of } \\
\text { City and Country. }\end{array}$ & $\begin{array}{l}\text { Divided the agricultural and non- } \\
\text { agricultural population }\end{array}$ \\
\hline 1956 & $\begin{array}{c}\text { Three Papers of the First National Hukou Work } \\
\text { Conference }\end{array}$ & $\begin{array}{l}\text { Established the three tasks of hukou } \\
\text { administration }\end{array}$ \\
\hline
\end{tabular}

Source: Lu Yilong (2002) ${ }^{259}$

The People's Republic of China Hukou Registration Regulation was adopted by the Standing Committee of the National People's Congress on 9 January 1958. Article 1 clearly sets out the rationale for these measures, stating, "This regulation is formulated in order to maintain social order, protect the rights and interests of citizens, and to be of service to the establishment of socialism." ${ }^{260}$ Lu Yilong argues that the law was designed primarily to establish social order and stability and to decrease migration pressures on the cities struggling with unemployment after decades of upheaval as well as to allow the government to establish 'work order' through the socialist planned

258 中华人民共和国户口登记条例.

${ }^{259} \mathrm{Lu}$ Yilong 陆益龙. "1949年后的中国户籍制度: 结构与变迁" [Structure and Transition: The Household Registration System in China after 1949].

260 “为了维持社会秩序，保护公民的权利和利益，服务于社会主义建设，制定本条例。”

People's Republic of China Hukou Registration Regulations 中华人民共和国户口登记条例 (1958). 
economy. ${ }^{261}$ Hukou regulations acted as a social control mechanism and as the

fundamental institutional tool for the bureaucracy and the economic planners of the day.

Table 3 summarises the main features of the 1958 regulation still in force today.

Table 3: Selected Summary of the 1958 PRC Hukou Registration Regulations

\begin{tabular}{|c|c|}
\hline $\operatorname{Article(s)}$ & Summary \\
\hline 2 & All citizens must carry out hukou registration. \\
\hline 3 & $\begin{array}{l}\text { All levels of the Public Security Bureau (PSB) are responsible for carrying out hukou } \\
\text { registration. Where appropriate 'work units', cooperatives and military institutions will } \\
\text { appoint people to register hukou with the PSB. }\end{array}$ \\
\hline 4 & $\begin{array}{l}\text { A register of hukou registrations should be kept by the PSB. Households in the city are } \\
\text { issued a hukou book by the PSB and in villages by rural cooperatives. Those in rural areas } \\
\text { not in cooperatives will not receive a hukou book. The hukou book is effective proof of } \\
\text { identity. }\end{array}$ \\
\hline $5 \& 6$ & $\begin{array}{l}\text { The head of households and work units are responsible for ensuring hukou registration. } \\
\text { Hukou registration is for the area most commonly lived in and this permanent hukou } \\
\text { residence can be one area only. }\end{array}$ \\
\hline 10 & $\begin{array}{l}\text { Citizens wishing to move outside of their hukou jurisdiction must declare their intention to } \\
\text { leave, obtain an outward migration certificate and cancel their hukou at their current hukou } \\
\text { registration organ (generally the PSB or local committee members) before leaving. } \\
\text { Citizens wishing to move from rural areas to the city must hold an employment permit } \\
\text { from the labour department in the city, an enrolment certificate from a school, or a } \\
\text { standard entrance permit from the city hukou registration organs in order to apply for an } \\
\text { outward migration certificate. } \\
\text { Those wishing to migrate to the frontiers must go through the hukou registration organ in } \\
\text { their jurisdiction. }\end{array}$ \\
\hline 13 & $\begin{array}{l}\text { After arriving at destination migrants must register with the hukou registration organ } \\
\text { within three days (city) or } 10 \text { days (countryside) and present their migration certificate for } \\
\text { cancellation as well as apply for an entrance permit. }\end{array}$ \\
\hline 15 & $\begin{array}{l}\text { Citizens outside the city of their hukou jurisdiction for more than } 3 \text { days must apply for } \\
\text { temporary registration from local authorities through their host household or hotel in the } \\
\text { city they are staying. These regulations do not apply in the countryside. }\end{array}$ \\
\hline 16 & $\begin{array}{l}\text { Citizens staying outside their hukou jurisdiction for more than } 3 \text { months must apply for an } \\
\text { extension. If there is no reason for extension or no impediment to migration then they } \\
\text { must return to their place of permanent hukou registration. }\end{array}$ \\
\hline
\end{tabular}

Source: People's Republic of China Hukou Registration Regulations (1958)

This summary shows that both outward and inward migration (temporary and permanent) are managed by the Public Security Bureau and that without going through the process of applying to leave, to migrate and to enter a new area, both temporary and permanent migration was essentially against these regulations. Moreover migration, most importantly permanent migration, from rural areas to urban areas was strictly controlled by the above process. It also shows the importance of the hukou institution to the command economy as 'work units' and cooperatives became responsible for hukou

${ }^{261} \mathrm{Lu}$ Yilong 陆益龙. "1949 年后的中国户籍制度: 结构与变迁" [Structure and Transition: The Household Registration System in China after 1949]. 
administration and applications, giving them extensive powers of management and social control. ${ }^{262}$ What is not mentioned clearly in the law is the institutionalised distinction between shimin 'city residents' and nongmin 'country residents' or 'agricultural and non-agricultural' ${ }^{\text {263 }}$ hukou. As of 2008 this regulation remains in effect and it therefore acts as the baseline for the current study. Further regulations were implemented after 1978 and these will be discussed later in this chapter. For now, the importance of the 1958 hukou law is stressed as its functioning remained largely intact (or even solidified) until the late 1970s. This significance includes its restriction on population movements (especially rural to urban migrations), the solidification of the division of rural and urban worlds (where the rural world supplied the resources to industrialise the urban world) and its functioning in the bureaucracy as a whole and the command economy in particular. These regulations gave the state phenomenal power over citizens' freedom and allowed them to attempt to control nearly all aspects of society.

Studies have shown that between 1958 and 1978 China's internal migration was 'static' meaning migrations were for the most part restricted to state planned migrations (migration with an official change of hukou location) and 'outside the plan' migrations (migrations without changing hukou status) were extremely low due to the impossibility of surviving 'outside the plan'. ${ }^{264}$ However, Diana Lary (1999) has critiqued the notion that pre-reform China was 'static', arguing, "The present growth in migration has to be seen in the context of its predecessors, that is, not only as absolute growth, but also as growth in visibility; we now see what was once hidden." ${ }^{265}$ This point highlights the

\footnotetext{
${ }^{262}$ Even today in contemporary China 单位 'work units' in the cities have the power to apply and be granted city hukou for their workers.

263 农业和非农业.

${ }^{264}$ Xiaogang Wu and Donald J. Treiman, "The Household Registration System and Social Stratification in China: 1955-1996," Demography 41, no. 2 (2004).

${ }^{265}$ Lary, "The "Static" Decades: Inter-Provincial Migration in Pre-Reform China." p.32.
} 
unknown quantity of non-state sanctioned pre-reform migration in China. 'Outside the plan' migration remained largely 'invisible' but many demographic studies, social reaction to the growth in the number of migrants in the city as well as official figures all strongly suggest that there has been a phenomenal growth in migration since 1978 making the term 'static' applicable to pre-reform internal Chinese migration due to the size of this difference. ${ }^{266}$

Turning to political and politico-economic migrations that were sanctioned or imposed by the state through transfer of hukou, better data is available and more studies have verified state use of the huji system as an instrument of political and command economy imperatives. Scholars estimate that between 1949 and 1953 the urban population grew by 20 million of which $70 \%$ is attributable to rural to urban migration; that an estimated 25 to 30 million people obtained hukou transfers from one province to another between 1949 and 1978; and that there were 50 to 60 million surviving rural to urban migrants living in urban areas in $1986 .{ }^{267}$ These figures are only estimates, due to the fact that the PRC census did not begin asking direct migration questions until $1990,{ }^{268}$ and to the lack of reliable empirical data collected by the Chinese bureaucracy and academics in pre-reform China. As way of illustration of the power the huji institution afforded the state, some examples of state-initiated migration are necessary. These include migration to the frontiers, command economy labour migrations, re-settlement migration for resource developments, nongmin conscription and political exile or re-education through labour camps.

\footnotetext{
${ }^{266}$ I.e. it is true that the size of migration figures (with and without hukou transfer) cannot be close to zero but also highly improbable that the numbers reached anywhere near the size of post-reform migration numbers (both sanctioned with hukou transfer and 'long-term temporary' migration without hukou transfer).

${ }^{267}$ Diana Lary (1996), V.F.S. Sit (1985) \& the Chinese Academy of Social Sciences (1988) cited in: Davin, Internal Migration in Contemporary China.

${ }^{268}$ I.e. the $1953,1964 \& 1982$ censuses did not record migration data.
} 
The first such phenomenon is government sponsored migration to border regions or frontiers of China that has been described as state-building, colonisation and an exertion of China's soft power. ${ }^{269}$ This occurred in Xinjiang, Ningxia, Qinghai, Inner Mongolia, Heilongjiang, Hainan and Yunnan. ${ }^{270}$ Greg Rohlf describes the process of border migration to Qinghai and Xinjiang provinces showing that first men and then women were moved to this region to consolidate the PRC, ROC and Qing Dynasty's territorial expansion and permanently establish sovereignty there. ${ }^{271}$ Yasheng Huang discusses the transfer policy and economic migration of Han Chinese to Tibet in the $1980 \mathrm{~s} .{ }^{272}$ Rong Ma and other scholars have researched the segregation of Tibetan and Han nationalities, income and housing differentials and the trouble of ethnic integration as a result of Han migration to Tibet since the 1950 s, both through the central government transfer policy and latter day economic migration. ${ }^{273}$ Rose Maria Li discusses Han migration to the northern frontiers to shore up the Sino-Soviet border and Henry G. Schwarz Han migration to north-west China and Inner Mongolia in the early communist period. ${ }^{274}$ These studies show that China's transfer policy was extensively used in the pre-reform period to move Han Chinese to border regions or frontiers of China and that it relied heavily on the huji institution.

Migrations and government transfer of hukou for the purposes of the command economy were also extensive during the pre-reform era. Technocrats, scholars and the highly educated were often moved to areas in need of skilled personnel. University

\footnotetext{
${ }^{269}$ Today migration to the frontiers is no longer planned and is primarily spontaneous and for economic reasons; though it is noted that this migration is still facilitated by the state with easier transfer of hukou than migration to other regions of China. See: Yasheng Huang, "China's Cadre Transfer Policy toward Tibet in the 1980s," Modern China 21, no. 2 (1995), p.184.

${ }^{270}$ Davin, Internal Migration in Contemporary China.

${ }^{271}$ Greg Rohlf, "Reproduction and State-Building Along China's Frontiers," China Information, no. 21 (2007).

${ }^{272}$ Huang, "China's Cadre Transfer Policy toward Tibet in the 1980s."

${ }^{273}$ Rong Ma, "Han and Tibetan Residential Patterns in Lhasa," The China Quarterly, no. 128 (1991).

${ }^{274}$ Rose Maria Li, "Migration to China's Northern Frontier, 1953-82," Population and Development Review 15, no. 3 (1989), Henry G. Schwarz, "Chinese Migration to North-West China and Inner Mongolia, 1949-59," The China Quarterly, no. 16 (1963).
} 
students could be assigned work in any region of China upon graduation. Nongmin were at times moved in from the communes through the issuing of temporary hukou permits to provide needed labour for factories and again moved out at the end of their contract via the revoking of their temporary permit. ${ }^{275}$ At the end of the disastrous Great Leap Forward (1958) even urban hukou holders were sent to live in the countryside with a transfer of hukou status in order to lessen the labour pressures and resource allocation pressures on the cities. A related phenomenon is forced re-settlement migration due to resource developments and infrastructure projects. Li et al describe the process of resettlement of mostly farmers in areas earmarked for reservoir development and show the socio-economic implications of such moves as well as the power the huji system gave to the economic planners of the command economy. ${ }^{276}$

Finally, nongmin conscription and political exile or re-education was also facilitated via the huji institution. Nongmin could be conscripted into the armed forces to defend the borders of China (such as in the Korean War) and those intellectuals, party members, bureaucrats or students with a prized urban hukou could be punished (or subdued through threat of punishment) through a change of hukou status from urban to rural and forced exile to the countryside or re-education through labour camps. ${ }^{277}$ Examples of this last instrumental function of the huji system occur throughout the 1949-1978 period but become almost common during the infamous Cultural Revolution era (1966-69 \& 1970-76). After the chaos and anarchy of the 1966-69 period a particularly authoritarian and arbitrary Chinese government instigated strict surveillance of urban residents and sent millions of urban people to live in the countryside. Mao's anti-urban rhetoric and this latter authoritarian period led to an estimated 17-20 million urban people, Red

\footnotetext{
275 Davin, Internal Migration in Contemporary China.

${ }^{276}$ Heming Li, Paul Waley, and Phil Rees, "Reservoir Resettlement in China: Past Experience and the Three Gorges Dam," The Geographical Journal 167, no. 3 (2001).

${ }^{277}$ Davin, Internal Migration in Contemporary China.
} 
Guards, intellectuals and the politically disgraced being forced to transfer their hukou and live in rural areas. ${ }^{278}$ These people, the urban Red Guards and intellectuals that missed out on education and career development, spent years trying to change back their hukou status to urban and brought back with them horror stories of the poverty and conditions of rural life that entrenched urban disdain for rural areas and nongmin that can still be seen in today's China. ${ }^{279}$ This policy facilitated by the huji institution had a negative affect on the 'sent down' youth; the lost generation of the disastrous Cultural Revolution. ${ }^{280}$

In summary, this brief historical review shows that one's hukou has been the 'first credential' for China's citizens for most of China's political history and concurrently this confers it with a large degree of legitimacy. The evolution of this institution over the last two millennia and the stability of it as a governing structure through dynastic, republican and communist times shows that today's huji institution remains heavily influenced by pre-modern arrangements. It is hoped the reader is left with a good understanding of the function and implementation of the institution and the needed background for understanding the significance of contemporary changes that make up the core focus of this research. Understanding China's huji reforms requires an understanding of the institutional arrangements and environmental circumstances inherited by the reform era. Turning to a review of the period of study (1978-2007) it becomes clear that institutions, particularly China's formal huji institution, matter a great deal in contemporary China.

\footnotetext{
278 Ibid.

${ }^{279}$ It is necessary to note that this is the everyday life of nongmin and the 'sent down' youth merely experienced it for a decade.

${ }^{280}$ Xueguang Zhou and Liren Hou, "Children of the Cultural Revolution: The State and the Life Course in the People's Republic of China," American Sociological Review 64, no. 1 (1999).
} 


\subsection{Institutions Matter}

"The roots of China's present migration problems lie in the policies of the first decades of the People's Republic. In this period the growing inequality between rural and urban areas set up conditions that would have been conducive to high-levels of rural-urban migration had free movement been permitted. To prevent this, the state set up institutional barriers to migration which, by the 1970s, had made spontaneous movement from a village to an urban area as difficult as movement across national frontiers elsewhere in the world. ${ }^{281}$

The core tenant of the institutionalist school is that institutions matter because they shape the behaviour of actors. The huji institution matters because it shapes the behaviour of China's citizen's and acts as a significant governing tool of the party-state to enforce its objectives. This idea will be explored in detail through analysis of the following themes over the reform era: the functioning of the huji institution; its significant role managing China's domestic migration; and the ongoing importance of hukou as a determinant of life opportunity. The final section of the chapter will then move on to focus on the reforms and asks how and why these reforms have come about.

\subsubsection{The Function of China's Huji Institution}

China's contemporary huji institution is not well known outside of China and yet it is the most important formal institution in China. ${ }^{282}$ Simply put, China's current huji institution is a system of population/migration management and control. Its most basic function is to record the identity and location of residents/households as any census system does or as 'hukou' systems in Taiwan, Korea and Japan do and as population management systems in premodern China did. However, China's huji institution is not merely a registration system (as the English translation 'household register' implies). ${ }^{283}$ This institution also acts as a system for: maintaining social stability; ${ }^{284}$ managing and restricting urbanisation and pressures on city governments through a quota system

\footnotetext{
${ }^{281}$ Davin, Internal Migration in Contemporary China. pp.18-19

${ }^{282}$ Tian Bingxin 田炳新. 《中国第一证件: 中国户籍制度调查手稿》 [China's First Credential: China's Huji System Research Manuscript].

${ }^{283}$ The English term 'household register' is written on all 户口簿 (hukou booklets) and is the official translation. However, this study uses the term hukou to avoid confusion with the more general understanding of what a household register is and to highlight the unique features of the huji institution in China. 284 维持社会秩序.
} 
limiting the number of hukou residency transfers to urban areas; allocating state resources within clearly defined hukou zones, ${ }^{285}$ and managing the command economy; ${ }^{286}$ and finally as a system that maintains social control and the central and local leadership of the Party-State.

The first major function of this institution is the government restriction on changing one's hukou location. Officially it is possible to change the location of one's hukou but in practice it remains extremely hard to officially change permanent residence to many urban areas. This limits the internal migrations of Chinese citizens and strictly controls legal settlement with official residence. This function is rationalised by the state as an essential means of maintaining social stability and management in a country of diverse ethnic and provincial identities as well as a country with immense population pressures. $^{287}$ As early as 1950 the new government issued the Interim Procedures Concerning Special Population Administration ${ }^{288}$ as a first step towards establishing the 1958 Hukou Registration Regulations. These measures were driven by a perceived need to bring order and stability to a state ravaged by decades of foreign invasion and civil war. ${ }^{289}$ Article 1 of the 1958 Hukou Registration Regulations clearly states: "This regulation is formulated in order to maintain social order, protect the rights and interests of citizens, and to be of service to the establishment of socialism." Whilst, officials, scholars and shimin today generally agree that 'nongmingong' are an essential part of the urban economy and a permanent fixture of city industry and life many still complain they lower wages, create crowding, increase the crime rate, put pressure on

\footnotetext{
285 户口区.

${ }^{286}$ In recent decades the market economy in China has grown rapidly. The command economy does however still exist, though operating differently from before. For example, SOEs will work for both government contracts and in the private economy.

${ }^{287}$ See: Wei Liqun 魏礼群, and Han Changfu 韩长赋, eds. 《中国农民工调研报告》[China's Nongmingong Research Report].

288 《关于特种人口管理的暂行办法》.

${ }^{289}$ Lu Yi-long 陆益龙. "1949 年后的中国户籍制度: 结构与变迁" [Structure and Transition: The Household Registration System in China after 1949].
} 
infrastructure such as transport, housing and roads and in many people's minds decrease the 'quality' ${ }^{290}$ of the city population. Thus, the issue of social order remains an important motivation for the maintenance of the huji institution.

The second important function of this institution is the dualistic division of hukou for city residents and hukou for rural residents, known as agricultural hukou and nonagricultural hukou, ${ }^{291}$ or as urban residential hukou and rural hukou, ${ }^{292}$ to reduce population pressures on already overpopulated cities and manage the urbanisation process synonymous with modernisation. ${ }^{293}$ One's hukou status is determined through family lineage (historically on the mother's side) in the same way international citizenship in many nation-states is, and like international citizenship in the more affluent and prosperous nation-states of the world, obtaining an urban hukou in China is highly sort after by those institutionally excluded from urban status by birth. “...There is one type of credential that symbolises a person's destiny as some are born with it and others are not. Even though this credential looks no finer than others ... it possesses the ability to enchant people with its magic... That credential is the urban residential hukou." ${ }^{294}$ Obtaining an urban residential hukou remains a dream of many rural migrants but the process of changing from rural to urban status is costly, complex and for most migrants far beyond their reach. "The key to regulating formal rural-to-urban migration under the hukou system is to control nongzhuanfei, ${ }^{295}$ which is subject to simultaneous 'policy' (zhengce) and 'quota' (zhibiao) controls. The former defines the

\footnotetext{
290 素质 suzhi: quality or educational level.

291 农业户口和非农业户口.

292 城市居民户口和农业户口.

${ }^{293}$ For research into the relationship between modernisation and urbanisation see: Lewis, The Theory of Economic Growth. In relation to China see: Wang, Organizing through Division and Exclusion: China's Hukou System.

${ }^{294}$ Tian Bingxin 田炳新. 《中国第一证件: 中国户籍制度调查手稿》[China's First Credential: China's Huji System Research Manuscript], p.1.

295 农转非 : transfer of agricultural hukou to non-agricultural hukou.
} 
qualifications of people entitled to non-agricultural hukou, whereas the latter regulates the number of qualified people who will get non-agricultural hukou." 296

With the vast majority of China's population institutionally defined as agricultural/rural residents (nongmin), the hukou institution acts as a means of controlling and managing the urbanisation pressures associated with industrial and economic modernization by limiting the amount of official urban residents and thus dissuading temporary migrants from settling in the city. ${ }^{297}$ Any visitor to Chinese cities can observe that tens of millions of nongmin migrate to the cities. What is not so obvious is that many basic public goods and services available to permanent residents as well as medical insurance, ${ }^{298}$ and housing benefits, ${ }^{299}$ remain beyond their reach. The residence permit forbids them permanent status leaving them 'doomed to remain migrants in the city'. 300 The phrase 移而不迁 to 'move but not to migrate' means nongmin move to the cities (working and residing there for long periods of time) but cannot officially 'migrate' as they cannot transfer their permanent hukou location due to a quota on the amount of transfers from agricultural to urban. ${ }^{301}$ The huji institution, as well as being a census also acts as the fundamental social and population control mechanism for both national and urban governments allowing them to limit the number of official residents in the cities and to limit access to certain government and private services in the relatively affluent urban areas to only those holding local urban residential hukou. For example, if

\footnotetext{
${ }^{296}$ Kam Wing Chan and Li Zhang, "The Hukou System and Rural-Urban Migration in China: Processes and Changes," The China Quarterly, no. 160 (1999), p.823.

${ }^{297}$ The benefits of having urban residential hukou in the city one resides in will be looked at fully in latter Chapters. For an interesting study on how hukou status affects one's opportunities see: Feng Wang and Xuejin Zuo, "Inside China's Cities: Institutional Barriers and Opportunities for Urban Migrants," The American Economic Review 89, no. 2 (1999).

${ }^{298}$ Ingrid Nielsen et al., "Which Rural Migrants Receive Social Insurance in Chinese Cities?," Global Social Policy 5, no. 3 (2005).

${ }^{299}$ Weiping Wu, "Migrant Housing in Urban China: Choices and Constraints," Urban Affairs Review 90, no. 119 (2002).

${ }^{300}$ Chen and Wu, Will the Boat Sink the Water? The Struggle of Peasants in 21st-Century China.

${ }^{301}$ Xu Zengyang 徐增阳."民工、民工问题与民工的 “终结” --国家治理视角的解读" [Mingong, Mingong Issues and the 'End' of Mingong: A New Perspective on National Governance]. 《中共宁波市 委党校学报》[Journal of the Party School of CPC Ningbo Municipal Committee], 29, no. 1 (2007).
} 
a rural hukou holder moves out of their hukou zone to find work in the city, if they cannot transfer their hukou to the zone they are living and working in, they will not be able to access public resources, such as, education for their children without either paying a fine or doing so illegally.

At the baseline year of this research (1978), China's huji institution functioned very differently from how it operated in 2007. Even though the 1958 PRC Hukou Registration Regulations are still in effect, the huji institution has gone through a number of important changes that are fundamentally linked to the politico-economic changes China has experienced during transition from a command economy to a socialist market economy or dual economy. ${ }^{302}$ To highlight these changes it is necessary to briefly discuss two functions fully operational in 1978: its fundamental role in the operation of the command economy; and its role in maintaining social control and adhesion to the dictates of the party-state in the non-pluralistic and non-liberalised government structure of the time.

The hukou institution was fundamental to the functioning of the state planned economy. Without such a system, planning would have been nigh impossible. As a comparison, the Soviet Union introduced the propiska system in 1932 for the purposes of the planned economy. ${ }^{303}$ Whilst the Soviet propiska system never functioned as effectively to prevent non-sanctioned migration as it did in China (perhaps due to the high degree of historical legitimacy for such a system in China), it was the first to institutionalise state socialism in which industrialisation in the cities was fuelled by an unequal

\footnotetext{
${ }^{302}$ Dual economy: the maintenance of government SOEs and monopolies whilst concurrently a market economy develops and grows alongside. See: Naughton, Growing out of the Plan: Chinese Economic Reform, 1978-1993.

${ }^{303}$ Fan, "The Elite, the Natives, and the Outsiders: Migration and Labor Market Segmentation in Urban China."
} 
exchange between rural and urban areas. ${ }^{304}$ China followed the Soviet model and the rural areas provided food and resources for the cities allowing the cities to focus on the task of industrialisation. The propiska and huji systems gave both communist governments the institutional tool by which to keep the 'peasants' on the communes producing agricultural resources and to enforce strict rationing of food, resources and work in the cities; thus maintaining tight control over the economy, the movement of residents and the division of rural and urban roles in economic affairs. ${ }^{305}$

In terms of governance, the huji system also functioned, and to a large degree still does function, as a system of social and political management. Prior to 1978, hukou determined access to state resources in the cities. This ensured Chinese citizens were responsive to state dictates because they could not survive without access to these resources in a state that lacked a market economy. Neighbourhoods and families were also 'mutually responsible' for their political conduct. In the countryside, collectivisation of rural residents into communes was used to keep a check on the populace, though checks and management of the population was not as strict as in the city. ${ }^{306}$ One's hukou could also be marked for special attention by the Public Security Bureau (PSB) and moved from the general huji register to the 'targeted population,307 register, a strategy utilised for both police work and political control. ${ }^{308}$ The huji system operates as the basis for government management of the permanent residence of Chinese citizens and, though less now than before, as the basis for managing the

\footnotetext{
${ }^{304}$ Chan and Zhang, "The Hukou System and Rural-Urban Migration in China: Processes and Changes."

${ }^{305}$ For a discussion of the influence of the Soviet model see: Ibid, M. R. Dutton, Policies and Punishment in China (Cambridge: Cambridge University Press, 1992).

${ }^{306}$ Lary, "The "Static" Decades: Inter-Provincial Migration in Pre-Reform China."

307 重点人口.

${ }^{308}$ Wang, Organizing through Division and Exclusion: China's Hukou System.
} 
movement and temporary residence of Chinese citizens. This has again been illustrated by the 'cleanup/security crackdown' of migrants prior to the Beijing Olympics. ${ }^{309}$

However, since the policy of 'reform and opening' the number of migrations neither planned by government institutions nor government sanctioned in terms of migrants changing their residential hukou to their destination has grown rapidly in comparison to China's 'static decades'. Most scholars agree that there are now well over 130 million nongmingong residing in Chinese cities without local urban hukou. ${ }^{310}$ As the institutional environment has changed, pressure to reform the institutional arrangements has built up. To illustrate this point and gain a better understanding of continuity and change in the institutional arrangements the following sections will review government efforts to manage domestic migration in the reform era, the ongoing significance of hukou status as a determinant of life opportunity and discuss the adaptations and endurance of the huji institution during China's great economic reforms and age of migration.

\subsubsection{Managing China's Domestic Migration}

"We need to divert more of the surplus rural labor to township and village enterprises and other businesses. We will guide migration of rural workers to urban areas to ensure that flow is orderly and absorb more of such workers into infrastructure development projects. ... Efforts should be made to set up a unified, open, competitive, and orderly labor market; reform the residence registration policy [huji system policy] in cities and towns, and gradually change the policy concerning change in residency in large and medium-sized cities, so that the rights of people to move and choose jobs freely can be guaranteed and the redistribution of human resources between cities and countryside and among various regions can be realized; and provide various services for migratory people by reforming the management system and setting up an efficient management network based on where the migratory people live and work. ${ }^{311}$

State organs, cadres and policymakers have vested interests in the current institutional arrangements and continue to take an active approach to controlling and managing rural

\footnotetext{
${ }^{309}$ During the 2008 Olympic Games, a security crackdown on nongmin without the correct paperwork ensured that during the Olympics most nongmingong left Beijing. See: Kitty Bu, "Beijing Olympic Clean up Sweeps out Migrant Workers," Reuters(21.07.2008), http://www.reuters.com/.

310 Goodkind and West, "China's Floating Population: Definitions, Data and Recent Findings."

${ }^{311}$ Xinhua News Agency, People's Republic of China Year Book (Beijing: Xinhua Publishing House, 2001)
} 
to urban migration. A comparative study of development and urbanisation trends in developing countries by Lin Fei (2006) acknowledges that in the long term rural-tourban migration in China is 'unpreventable' but also argues that certain 'countermeasures' to urbanisation can be taken, such as diffuse urbanisation or developing non-agricultural employment opportunities in town and rural areas (decentralisation), to avoid the plight of millions of impoverished migrants in urban areas or to at least ameliorate urbanisation pressures on the cities. ${ }^{312}$ To this aim Chinese policymakers are promoting the strategy of chengzhenhua, ${ }^{313}$ which involves: urbanising China's less populated 'towns' and satellite cities; integrating rural and urban areas; and dissuading the further development of the cities through the transfer of large amounts of rural people that is deemed 'impossible' by many Chinese scholars and policymakers due to China's large rural population. ${ }^{314}$

In the early 1980 s the government promulgated the small town policy to try to stem the already developing trend of rural-to-urban migration. ${ }^{315}$ Excess rural labourers were to 'leave the land but not the village' or 'leave the village but not enter the city., 316 Nongmin were encouraged to take up work in 'town and village enterprises' (TVEs) ${ }^{317}$ and could obtain special tax concessions and incentives and 'self-supporting urban hukou permits'. ${ }^{318}$ This newly created permit was only available to nongmin in small

\footnotetext{
${ }^{312}$ Lin Fei 林斐. "人口流动与城乡发展 : 探索发展中国家的经验" [Population Migration and UrbanRural Development: Exploring the Experiences of Developing Countries]. 《重庆工商大学学报（西部 论坛）》[Journal of Chonqing Technical and Business University (West Forum)], 16, no. 6 (2006). 313 城镇化 chengzhenhua: 'urbanization to towns' or 'urbanization from below'. 城市化 chengshihua: urbanisation or 'urbanisation from above'.

${ }^{314}$ Zhu Konglai 朱孔来, and Li Hongze 李洪泽. "城市化与城镇化的区别和联系" [Distinguishing and Relating Chengshihua and Chengzhenhua], 《时代金融》 [Times Finance], no. 5 (2006).

${ }^{315}$ Linda Wong and Wai-Po Huen, "Reforming the Household Registration System: A Preliminary Glimpse of the Blue Chop Household Registration System in Shanghai and Shenzhen," The International Migration Review 32, no. 4 (1998).

316 离土不离乡 and 离乡不进城.

317 乡镇企业.

318 自理口粮城镇户口.
} 
towns and not to those in larger cities. ${ }^{319}$ By 1995 as many as 120 million rural labourers had found work in rural industries. ${ }^{320}$ Early studies show this policy has been successful at 'urbanising' and providing employment for many of the excess rural labourers and identified the possibility of it creating a new track of 'urbanisation from below'. ${ }^{321}$ However, Liang et al's (2002) study found, “...rural industrialisation does not have a statistically significant impact on the probability of either intraprovincial or interprovincial migration. ... The lack of a statistically significant effect of rural enterprises on migration casts serious doubt on the efficacy of using rural enterprises as a strategy to stem peasants from migrating to other places." 322

Therefore, the state, aided by the huji institution, continues to macro-manage China's urbanisation process and attempt to 'circumvent the Lewis Transition'. ${ }^{323}$ Whilst departing from the policy of strictly preventing rural-to-urban migration, as done in the Mao era, they continue to initiate and encourage migration and settlement of some citizens to some areas and prevent and dissuade migration and permanent settlement to other areas. In the long run most studies predict the market will become the predominant determiner of migration flows but in the near future the role the state continues to play in managing and trying to circumvent urbanisation remains an important variable in the study of China's domestic migration patterns.

\footnotetext{
${ }^{319}$ Davin, Internal Migration in Contemporary China.

${ }^{320}$ Ibid, p.41.

${ }^{321}$ C. Cindy Fan, "Urbanisation from Below: The Growth of Towns in Jiangsu, China," Urban Studies 31, no. 10 (1994), Ma and Lin, "Development of Towns in China: A Case Study of Guangdong Province."

${ }^{322}$ Zai Liang, Yiu Por Chen, and Yanmin Gu, "Rural Industrialization and Internal Migration in China," Urban Studies 39, no. 12 (2002), p.2175 and p.2185.

${ }^{323}$ Wang, Organizing through Division and Exclusion: China's Hukou System.
} 


\subsubsection{Hukou as a Determinant of Life Opportunity}

That institutions matter to China's domestic migration patterns is clear when looking at the affect a migrants' hukou 'status' has on their life opportunities. The huji institution, particularly after 1958, solidified and institutionalised the division of rural and urban areas in China and kept tight control over rural-to-urban migration and settlement. From the mid-1980s, nongmin increasingly worked and resided in urban areas-for most without changing their permanent hukou status to their new place of residence. Based on hukou status at destination (hukou migrants; non-hukou migrants; and temporary visa migrants), and hukou status at origin (agricultural nongmin or non-agricultural shimin), China's urban migrants now fall into six broad categories (see Table 4).

Table 4: Type of Urban Migrant as Defined by Hukou Status

\begin{tabular}{|c|c|c|c|}
\hline Hukou Status & $\begin{array}{c}\text { Hukou Migrant at } \\
\text { Destination }\end{array}$ & $\begin{array}{c}\text { Temporary Visa Migrant } \\
\text { at Destination }\end{array}$ & $\begin{array}{c}\text { Non-Hukou Migrant at } \\
\text { Destination }\end{array}$ \\
\hline $\begin{array}{c}\text { Non- } \\
\text { Agricultural } \\
\text { Hukou } \\
\text { at Origin } \\
\text { (Shimin) }\end{array}$ & $\begin{array}{c}\text { Obtain transfer of } \\
\text { permanent hukou to } \\
\text { new urban destination. }\end{array}$ & $\begin{array}{c}\text { Permanent hukou destination } \\
\text { remains in the city of origin } \\
\text { these migrants to work at } \\
\text { origin and have some access } \\
\text { to government services. }\end{array}$ & $\begin{array}{c}\text { Fail to gain transfer of } \\
\text { permanent hukou location or } \\
\text { be issued with temporary } \\
\text { work and resident permits. } \\
\text { No access to government } \\
\text { services at destination. }\end{array}$ \\
\hline $\begin{array}{c}\text { Agricultural } \\
\text { Hukou } \\
\text { at Origin } \\
\text { (Nongmin) }\end{array}$ & $\begin{array}{c}\text { Obtain transfer of } \\
\text { hukou to new } \\
\text { change status from } \\
\text { nongmin to shimin. } \\
\text { (农转非) }\end{array}$ & $\begin{array}{c}\text { the destination urban area } \\
\text { and have some access to } \\
\text { government services. }\end{array}$ & $\begin{array}{c}\text { nongmin and are illegally } \\
\text { residing and working in } \\
\text { China's urban areas. }\end{array}$ \\
\hline
\end{tabular}

Hukou status at origin is significant for determining the life opportunity of China's migrants, including their chance of gaining white collar work and obtaining hukou transfer to destination. Migrants in urban areas with non-agricultural hukou status at origin are considerably better placed than migrants with agricultural hukou status at origin. Whilst research is lacking on urban-to-urban migrations, current studies suggest 
these migrants have the following advantages. They have the safety net of being able to return to their original urban residence where they maintain urban status and benefits if they fail to transfer hukou to destination or obtain employment. ${ }^{324}$ They have better education and training due to growing up in urban areas with better infrastructure and investment. ${ }^{325}$ They have more chance of prospering in the market economy and/or obtaining secure work for the state in 'work units ${ }^{326}$ (thereby also usually obtaining hukou transfer to destination). ${ }^{327}$ Even among non-hukou migrants at destination, nonagricultural hukou holders were more likely than agricultural hukou holders to work in prestigious occupations. ${ }^{328}$ Finally, they have a far better chance of earning enough money to effectively bypass the state by relying on their purchasing power in the private economy. ${ }^{329}$ Urban migrants with agricultural hukou status at origin remain in a disadvantaged position:

"A migrant with an agricultural hukou status is unlikely to land a job with a large, stable employer, while one with a non-agricultural status is more likely to do so, even though they both have temporary status... One's non-agricultural hukou, even registered somewhere else, seems to have continuous effects on one's chance of landing a job with particular employers, as well as one's chance [of] having a white-collar job. Thus, hukou, the institutionalised social status inherited from one's family, continues to have strong effects on a person's life chances... [as] ... access to certain enterprises or occupations is largely determined by it. ${ }^{\not 330}$

The vast majority of all migrants in China are rural-to-urban migrants with agricultural hukou status at origin and the vast majority of these migrants fail to obtain hukou transfer (农转非) to destination. ${ }^{331}$ “The State Planning Commission ... sets the quotas

\footnotetext{
${ }^{324}$ Rural migrants also have the 'safety net' of returning to the village or to their 'plot of land'. Of course, as urban infrastructure, public goods and social welfare are far better in most urban areas the safety net of shimin migrants is far superior to that of nongmingong.

${ }^{325}$ Wu and Treiman, "The Household Registration System and Social Stratification in China: 1955-1996." 326 单位.

${ }^{327}$ Fei Guo and Robyn Iredale, "The Impact of Hukou Status on Migrants' Employment: Findings from the 1997 Beijing Migrant Census," International Migration Review 38, no. 2 (2004).

${ }^{328}$ Zai Liang, "Patterns of Migration and Occupational Attainment in Contemporary China: 1985-1990," Development and Society 33, no. 2 (2004).

${ }^{329}$ Wang, Organizing through Division and Exclusion: China's Hukou System.

${ }^{330}$ Guo and Iredale, "The Impact of Hukou Status on Migrants' Employment: Findings from the 1997 Beijing Migrant Census." pp.728-729.

${ }^{331}$ Siming Li, "Population Migration and Urbanization in China: A Comparative Analysis of the 1990 Population Census and the 1995 National One Percent Sample Population Survey," The International Migration Review 38, no. 2 (2004).
} 
and monitors cross-regional and especially rural-to-urban migration..." which makes hukou transfer for most nongmin an impossible dream. Figures from the 1980s suggest China's annual cross-provincial rate of hukou transfer (qianyi) ${ }^{332}$ was only 0.196 percent showing that transfer of hukou from rural to urban is tightly controlled by the state. ${ }^{333}$ One study found that only education, Party membership, and military service 'facilitate hukou mobility' for China's nongmin. ${ }^{334}$ Wang (2005) argues that increasingly 'what one has' is also becoming an important determinant of an agricultural resident's ability to transfer their hukou status to an urban destination. Wang notes that to transfer hukou status using wealth, nongmin must be extremely welloff as, "...the hukou police generate large sums of extrabudgetary income from those seeking favors in regard to hukou matters, especially hukou relocation..." in the form of fees, investment criteria and simple bribes. ${ }^{335}$ Overall, hukou transfer to destination for nongmin remains tightly controlled by the state meaning the vast majority of nongmingong are non-hukou migrants at destination.

"Hukou interprovincial migrants tended to originate from urban areas, had a highly skewed share of the college-educated, and were employed in higher-skilled jobs, while non-hukou migrants were mostly from rural areas with much lower educational attainment. They were also mostly in occupations with lower skill levels. In job-related migration, hukou migrants tended to move through government and formal channels, while non-hukou migrants relied on their own, often informal, channels for jobs. ${ }^{1336}$

Hukou status at destination (hukou; non-hukou; temporary permit) is also significant for determining the life opportunity of China's migrants, and differences between these types of migrants can be identified. Hukou migrants primarily have non-agricultural status; are local; are more permanent in their migration; and perform more skilled work in permanent jobs. Hukou migrants are more likely than non-hukou migrants to work in

332 迁移 qianyi refers to migration where ones hukou is transferred from origin to destination. This figure therefore omits non-hukou or 'temporary' migration.

${ }^{333}$ Wang, Organizing through Division and Exclusion: China's Hukou System, p.58 and p.64.

${ }^{334}$ Wu and Treiman, "The Household Registration System and Social Stratification in China: 1955-1996." p.380.

${ }^{335}$ Wang, Organizing through Division and Exclusion: China's Hukou System.

${ }^{336}$ Kam Wing Chan, Ta Liu, and Yunyan Yang, "Hukou and Non-Hukou Migrants in China:

Comparisons and Contrasts," International Journal of Population Geography, no. 5 (1999), p.442. 
prestigious occupations. ${ }^{337}$ Non-hukou migrants primarily have agricultural status; are illegal or 'temporary' migrants; and are involved in mostly unskilled or low-skilled work. ${ }^{338}$ They bear the brunt of not only divisive hukou policies but also discriminatory social stereotypes. Further studies show that, "City governments have pursued active policies of regulating the inflow of migrants in order to protect their residents. [A] ...a city labour bureau was found to classify jobs into three types: urban hukou jobs, rural migrant jobs, and jobs open to all but with urban workers receiving preference. It also imposes quotas on the number of migrants that each enterprise can employ...",339 One further study comparing nonmigrant urban natives, hukou migrants and non-hukou migrants concludes that, "resident status is central to explaining migration processes and labor market segmentation in the Chinese city... Permanent migrants [with hukou transfer] are the most privileged and successful elite, followed by nonmigrant natives, and finally by temporary migrants [no hukou transfer] at the bottom of the hierarchy., 340

Non-hukou migrants can also be categorised as those legally working in the cities having obtained all the relevant official permits (temporary work and residency permits), and those that are 'floating', having never obtained the correct temporary permits. This former group, are non-hukou migrants at destination but they can legally reside and work in urban areas without changing their permanent hukou location and status as long as they apply for, pay and are granted a variety of temporary visas (though many do not) that are similar to visas needed by migrants crossing nation-state borders to reside or work temporarily in other countries. The later group, non-hukou migrants without temporary residence, can be hard to gather statistics on as they generally try to remain aloof of government authorities to avoid either being sent back to their permanent hukou

\footnotetext{
${ }^{337}$ Liang, "Patterns of Migration and Occupational Attainment in Contemporary China: 1985-1990."

${ }^{338}$ Chan, Liu, and Yang, "Hukou and Non-Hukou Migrants in China: Comparisons and Contrasts."

${ }^{339}$ Knight, Song, and Jia, "Chinese Rural Migrants in Urban Enterprises: Three Perspectives." p.97.

${ }^{340}$ Fan, "The Elite, the Natives, and the Outsiders: Migration and Labor Market Segmentation in Urban China." p.103.
} 
location or fined for not having the correct permits to reside or work in urban areas. ${ }^{341}$ They predominantly have agricultural status at origin and are commonly referred to as the floating population or nongmingong. ${ }^{342}$

Therefore, clearly the hukou institution acts both as a means of positive and negative discrimination for migrants in urban areas, with some receiving the benefits of hukou transfer and others not, and as a means for the state to influence economic development (transferring hukou for 'desirable' migrants only) and maintain political stability (by positively discriminating for shimin). Goldman and Perry (2002) trace the changing notions of citizenship in China over the 'cataclysmic twentieth century' and define citizenship, “...primarily as political, civil, and legal relations between members of society and the state..."343 They argue that, "although China is moving steadily toward a legal system intended to buttress its new market economy, its population still lacks a developed sense of individual rights and a legal system capable of enforcing them.” ${ }^{344}$ The right to equality enshrined in the constitution and the new Labour Law that replaces the 1995 one and is effective January $1^{\text {st }} 2008$ both question the legality and functioning of China's huji institution. This said, the huji system of 2007 and the associated rights and privileges differ considerably to that of 1978. These changes are discussed in the following section.

\footnotetext{
${ }^{341}$ Mallee, "Migration, Hukou and Resistance in Reform China."

${ }^{342}$ Non-hukou migrants with temporary permits are also commonly referred to as the floating population or nongmingong.

${ }^{343}$ Merle Goldman and Elizabeth J. Perry, "Introduction: Political Citizenship in Modern China," in Changing Meanings of Citizenship in Modern China, ed. Merle Goldman and Elizabeth J. Perry (Cambridge: Harvard University Press, 2002), p.17.

${ }^{344}$ Ibid, p. 17.
} 


\subsection{Institutions Adapt and Endure - But Why and How?}

"The impact of the economic reforms since 1978 has undermined the state's ability to suppress rural-urban migration and has created pressure for reform of the household registration system. The response of the state has been cautious. It has reversed Maoist policies designed to limit urbanisation and has recognised that urbanisation is a necessary and desirable development for China, but at the same time it tries to keep control of the type of urbanisation that occurs. [The huji institution endures because] ...the system is embedded in and supports the functioning of China's whole economic and social system. It is a means of social control for the state, but also underpins much social stratification and allows a particular form of labour market segmentation. ... It seems probable that the Chinese state will for some time be too fearful of the consequences to attempt the abolition of household registration. It will therefore be forced to continue to modify and adapt the system, attempting to reconcile it with the needs of a modern economy. ${ }^{3345}$

During the first decade of reform "...the governance of China encountered the consequences of the weakening of pre-existing systems of internal control such as the hukou and danwei systems and was confronted by the societal challenges of marketization and unbalanced regionalized development."346 The state allowed criticism of the huji system and discussion of how it might be reformed. Successful experimental modifications tried at the local level were introduced at the national level. Of these, the seven most important changes to the huji system over the thirty year reform period are: allowing some agricultural residents to live in certain urban areas; introducing temporary registration; introducing a national identity card; selling urban hukou; introducing the 'green card'; removing some restrictions on the transfer of hukou; and experimenting with non-dualistic hukou regulations entitling people with 'stable work and residence' to obtain hukou transfer in selected urban areas.

The first and most significant adaptation of the functioning of the huji institution occurred at the beginning of the reform era. Rural residents moved to urban areas in ever increasing numbers from the late 1970s but not until 1983 did the State Council 'allow' rural households to take up cooperative ventures in market towns without

\footnotetext{
${ }^{345}$ Davin, Internal Migration in Contemporary China, p. 39 \& p.48.

${ }^{346}$ Brian Hook, "China in the First Decade of Reform and Opening Out: An Edited View," The China Quarterly, no. 143 (1995), p.678.
} 
changing their status. ${ }^{347}$ As mentioned earlier, in 1984, as part of the strategy to macromanage China's urbanisation, officials moved to legalise and manage the movement of nongmin to urban areas. The State Council Circular on the Problem of Peasants' Settlement in Market Towns permitted nongmin to transfer their hukou to a market town so long as they found employment, had a stable residence and could take care of their own food rations. ${ }^{348}$ Entry into small towns was eased with the introduction of the 'small town self-supplying grain hukou', 349 and by 19864.6 million nongmin had given up their contracted land in the country and transferred their hukou to these small towns, though this number decreased thereafter. However, this urban hukou remained inferior to normal urban hukou as it did not provide the holder with a right to housing, subsidised healthcare or a guaranteed food supply. ${ }^{350}$ At the lowest level of the urban hierarchy this hukou became known as 'fake urban hukou'. 351

Secondly, the Provisional Regulations Regarding the Management of Temporary Residents in Cities and Towns was introduced by the Ministry of Public Security (PSB) in $1985 .^{352}$ This was a significant adaptation of the 1958 Hukou Regulations which were being increasingly ignored by nongmingong. Temporary permits allowed urban governments to address concerns of the urban population that nongmin were creating social ills and to "...legalise the migrant presence in the city without concomitant increase in the non-agricultural population." 353 Temporary residence cards were issued for six months or for one year and were renewable. ${ }^{354}$ Through these the state not only

\footnotetext{
${ }^{347}$ Wong and Huen, "Reforming the Household Registration System: A Preliminary Glimpse of the Blue Chop Household Registration System in Shanghai and Shenzhen."

348 Ibid.

349 自理口粮城镇户口.

${ }^{350}$ Davin, Internal Migration in Contemporary China.

${ }^{351}$ Wong and Huen, "Reforming the Household Registration System: A Preliminary Glimpse of the Blue Chop Household Registration System in Shanghai and Shenzhen."

352 《关于城镇暂住人口管理暂行规定》.

${ }^{353}$ Davin, Internal Migration in Contemporary China, p.48.

${ }^{354}$ These were called: 寄住证 ('card for residents living with others') for labourers and 暂住证 ('temporary residence card') for everyone else.
} 
regained some management of the migrant population but urban local organs of the PSB also gained a new revenue source from the issuing of permits. ${ }^{355}$ The cheap flexible labour force being recruited for contract work became legal for employers; but more significantly, temporary permits legalised the work of migrants in urban areas and gave, "...implicit recognition that the coming of peasants to towns was now a fact of life, thereby tacitly legitimizing the indefinite presence of peasants in cities of all sizes."

Thirdly, the Regulation on Resident Identity Cards in the People's Republic of China was introduced in $1985 .{ }^{357}$ These regulations were not intended to replace the huji system but did shift the focus of registration away from the household or unit (such as a military unit or work unit) to the individual and provided a nationalised identification system. ${ }^{358}$ The identification card is used for all formal and legal procedures in China. Sometimes touted as a replacement to hukou, at best it is an indication of a future move towards a more unified and nationalised system of registration and residency. At present it has no bearing on a citizen's hukou status and this remains a citizen's most important credential.

Fourthly, in 1988 Lai'an and Quanjiao counties of Anhui Province started selling urban hukou and by 1992 almost all provinces had launched similar schemes for selling local urban hukou. ${ }^{359}$ Whilst hukou transfer remained limited and subject to control by various state organs most small and large cities were selling urban hukou in the

\footnotetext{
${ }^{355}$ Registration for temporary residence remains low due to the lack of benefits of the scheme and the varying extremes of high fees paid to the local PSB. See: Wong and Huen, "Reforming the Household Registration System: A Preliminary Glimpse of the Blue Chop Household Registration System in Shanghai and Shenzhen."

${ }^{356}$ Solinger, Contesting Citizenship in Urban China: Peasant Migrants, the State, and the Logic of the Market, p.50.

${ }^{357}$ Wong and Huen, "Reforming the Household Registration System: A Preliminary Glimpse of the Blue Chop Household Registration System in Shanghai and Shenzhen."

${ }^{358}$ Davin, Internal Migration in Contemporary China.

${ }^{359}$ Wong and Huen, "Reforming the Household Registration System: A Preliminary Glimpse of the Blue Chop Household Registration System in Shanghai and Shenzhen."
} 
1990s. ${ }^{360}$ The extra income gained from this varied but generally the price was high reflecting the value and demand for urban hukou. Solinger (1999) notes that, "Perhaps because of the ongoing smaller-scale bribery in which individual public security and labor officials had been engaging in continuously, it was often unclear, even in the official media, whether or not the practice of levying fees for access to the city (or the related one of selling hukou) was illicit or not." ${ }^{, 361}$ The State Council and Ministry of Public Security had published regulations forbidding the sale of urban hukou in late 1988 and again in mid-1992, though this phenomenon still continues. Moreover, in Beijing, migrants could obtain a set of 3 urban hukou if they could afford to buy in cash a Beijing apartment $(500,000 \mathrm{RMB}$ or more) or paid local taxes of $800,000 \mathrm{RMB} / \mathrm{year}$ for three consecutive years - a possibility only for the relatively few multimillionaires in China. ${ }^{362}$ The sale of urban hukou, fees for temporary permits and transfer of hukou based on investment and wealth has become an important form of revenue for local urban governments and a means for the newly wealthy to obtain previously unobtainable urban hukou in their destination city of choice.

Fifthly, the 'green card', 'blue card' or 'blue chop household registration, ${ }^{363}$ was first trialled in Qinlan Township in Tianchang County, Anhui Province in $1986 .{ }^{364}$ This scheme was modelled on the US 'Green Card' and had a status between temporary residency and permanent household registration. Applicants needed work or business skills and to pay a 5000 yuan fee. The trial proved very popular with migrants and spread very quickly in the 1990s with Shanghai adopting the scheme in 1994 and Shenzhen in 1996. Green cards are subject to quota, strict eligibility criteria and are

\footnotetext{
${ }^{360}$ Davin, Internal Migration in Contemporary China.

${ }^{361}$ Solinger, Contesting Citizenship in Urban China: Peasant Migrants, the State, and the Logic of the Market, pp. 89-90.

${ }^{362}$ Wang, Organizing through Division and Exclusion: China's Hukou System.

363 绿卡、蓝卡、蓝印户口.

${ }^{364}$ Wong and Huen, "Reforming the Household Registration System: A Preliminary Glimpse of the Blue Chop Household Registration System in Shanghai and Shenzhen."
} 
designed to attract skilled workers to urban areas. ${ }^{365}$ Notably, like temporary permits, holders of the card are not conferred the same hukou status as local urban hukou holders. Moreover, the majority of holders are already urban hukou holders from another location as rural migrants lack the finances, skills/education and assets to obtain them. $^{366}$

Sixthly, the state removed some restrictions on hukou transfer in the late 1990s and early 2000s as reforms intensified. In 1998 the State Council approved a Ministry of Public Security proposal removing some restrictions on internal migration, including: allowing those younger than 18 to choose the parent they inherit hukou from; facilitating hukou conversions for spouses; prioritizing hukou conversions for aged people who depend on their children for care; and facilitating the hukou conversion of investors and professionals and their family members. In 2000, the government began eliminating quotas limiting hukou registration in small cities and towns. In 2001 a State Council circular ordered small cities of less than 100,000 to grant hukou status to residents with fixed work and residence. And in 2003, the Ministry of Public Security approved additional measures aimed at easing travel restrictions, particularly in western areas. $^{367}$

Finally, recent experiments and calls for action regarding hukou reform have involved experimenting with non-dualistic hukou regulations entitling people with 'stable work and residence' to obtain hukou transfer in selected urban areas. Fuzhou, the capital city of Fujian Province, eliminated the rural/urban divide in 2002 and did away with the city

\footnotetext{
${ }^{365}$ Green Cards are very similar to the 'skilled' and 'investment' migrant categories in developed countries.

${ }^{366}$ Wong and Huen, "Reforming the Household Registration System: A Preliminary Glimpse of the Blue Chop Household Registration System in Shanghai and Shenzhen."

${ }^{367}$ Research Directorate, "Issue Paper: China: Reforms of the Household Registration System (Hukou) (1998-2004)," ed. Immigration and Refugee Board of Canada (http://www.irb-

cisr.gc.ca/en/research/publications/index_e.htm?docid=279\&cid=50\&sec=TOC, 2005).
} 
quota. ${ }^{368}$ In early 2003, 34 representatives headed by Lu Binghua submitted a bill to the National People's Congress (NPC), arguing, “...the Provision on Household Registration endorsed in 1958 could no longer meet the needs for economic and social development in China, thus reform of household registration has become an imperative task." ${ }^{369}$ These representatives proposed basic freedom to move and the right to obtain hukou registration providing a citizen has stable residence or work in that area. They met with opposition from those officials and representatives arguing completely lifting restrictions on free movement would put too much pressure on urban areas.

The last experiment involved strengthening the existing huji and identification systems. In early 2000 the PSB began computerising the huji system and in 2001 the national hukou information database was created as part of the 'Golden Shield' project to improve communication between police. ${ }^{370}$ This has greatly aided the work of the PSB and the ability of urban authorities and central government to manage China's population. This reform has not fundamentally changed the governance of the huji institution.

In general, these measures have liberalized the huji system in smaller urban areas and restricted transfer to only those with at least fixed residence and employment. Criteria in larger and more desirable urban areas generally involve higher fees, more specific employment and wealth criteria and are subject to stricter quotas. Therefore, it is apparent that the huji institution has adapted to the changing politico-economic environment of China's reform era but the fundamental function of the huji institution as a form of division and exclusion remains. The role of state-led reform, the role of

\footnotetext{
368 Ibid.

${ }^{369}$ People's Daily, "China to Make New Household Registration Law," People's Daily, 13.09.2007 24.02.2005.

${ }^{370}$ Research Directorate, "Issue Paper: China: Reforms of the Household Registration System (Hukou) (1998-2004)."
} 
markets and the role of migrants all go some way to explaining this change and endurance but a more unified approach is needed to get a more complex understanding of the exact dynamics of that change.

\subsection{Conclusion}

This chapter has reviewed the long history of internal migration controls in China and the role of the state in China's 'age of migration' and transitional period. Evidence suggests that one's hukou remains 'China's first credential' and show clearly that institutions matter. In China, the location of one's permanent hukou and whether a citizen has agricultural or non-agricultural status still largely determines a migrant's opportunity in life. Six categories of hukou status for migrants in urban areas were identified based on a migrant's hukou at origin (agricultural/non-agricultural) and hukou at destination (transfer to new location; obtain temporary visas; or fail to obtain transfer or temporary visas). Each category had its own institutional implications for migrants in China; thus reiterating the importance of the huji institution to China's migrating citizens. The review has also shown that the huji institution, whilst clearly maintaining many of its primary functions, has undergone some major changes and identified a debate in the literature between those who give primacy to the role of markets, the role of migrant agency or the role of elite-led policy objectives in these reforms. This debate is ongoing and remains important not only for gaining a better understanding of China's transitional period but also for gaining insight into the broad question of institutional change and endurance. The next chapter will analyse changes to the formal huji regulations at the national level over the period of study. 


\section{Case 1: Institutional Change at the National Level}

"Since 'reform and opening' and in the wake of China's quickening process of industrialization and urbanization, an increasing amount of excess rural labour has been moving to cities (towns) and rural and town enterprises. Through this process a special social group is forming... Nongmingong are predominantly defined by their hukou status remaining 'rural' when they enter cities to work or are engaged in non-agricultural work in their local area or other areas of China." ${ }^{371}$

"We need to divert more of the surplus rural labor to township and village enterprises and other businesses. We will guide migration of rural workers to urban areas to ensure that flow is orderly and absorb more of such workers into infrastructure development projects. Efforts should be made to set up a unified, open, competitive, and orderly labor market; reform the residence registration policy in cities and towns, and gradually change the policy concerning change in residency in large and medium-sized cities...,372

At the baseline of this study, huji regulations and implementation were guided by four fundamental objectives: allocate state resources and manage labour supply and demand to promote economic development; maintain social stability; manage and restrict migration and urbanisation; and strengthen control of the party-state. These objectives have guided huji policy over the reform era providing continuity and structure. However, changing socio-economic conditions have forced the central and local authorities to change the way hukou management is carried out, involving the introduction of temporary permits in the mid 1980 s and a series of experiments and incremental reforms of hukou transfer and nongzhuanfei in the 1990s and 2000s. China's central and local authorities have successfully adapted the operation of the huji institution to the new politico-economic imperatives to meet existing huji objectives but an emerging civic rights movement is increasingly pressuring central and local government for greater reform.

\footnotetext{
${ }^{371}$ Wei Liqun 魏礼群. "正确认识和高度重视解决农民工问题（代序言）" [Properly Recognising and Placing High Importance on Resolving the Nongmingong Issue (Preface)]. In《中国农民工调研报告/国 务院研究室课题组》[China's Nongmingong Research Report/Discussion Group of the Research Department of the State Council], edited by Wei Liqun 魏礼群 and Han Changfu 韩长赋.北京 [Beijing]: 中国言实出版社 [China Yanshi Press], 2006, p.1.

${ }^{372}$ National Bureau of Statistics of China, "People's Republic of China Yearbook," (Beijing: National Bureau of Statistics of China, 2001).
} 


\subsection{Prioritising Economic Development}

In 2003 Cai and Lin wrote, “China's greatest competitive advantage is none other than its abundant labour resource and cheap labour costs." ${ }^{\text {,73 }}$ That competitive advantage stems from the incremental and managed transfer of the world's largest primary industry labour force into tertiary and secondary industries. A managed transfer has been made possible through the use of China's centuries old huji institution which rigidly divides agricultural and non-agricultural hukou and local and non-local hukou. To manage the transfer the state responded to the growing trend of agricultural hukou holders engaging in non-agricultural employment outside their permanent hukou location by introducing a new form of temporary residency. This was controlled by local authorities keen to promote economic development and maintain social stability. The temporary visa provided industry with a powerful labour force which local authorities could maintain some degree of control over through the issuing of permits. Central authorities focused squarely on promoting rapid economic development through managed labour transfer as opposed to rapid liberalisation of the residency scheme. Whilst a 'temporary' labour market has been created by transfer of the rural labour force into urban employment through controlled temporary permits, liberalisation of control of hukou transfer for settlement has lagged far behind. The huji institution has been adapted by the MPS in line with the overall changing role of the state in the economy over the reform era. To do this the architects of huji regulations significantly changed one of its primary objectives from administrating the socialist planned economy to facilitating the socialist market economy through managed labour transfer.

\footnotetext{
${ }^{373}$ Cai Fang 蔡昉, and Lin Yifu 林毅夫. 《中国经济》[Chinese Economy]. 北京 [Beijing]: 中国财政 经济出版社 [China Finance Economics Publishing House], 2003.
} 


\subsubsection{Early Trends \& Early Reform}

In the 1970s China's central planners managed supply and demand forces through fixed prices and quotas. Urban and rural economies were divided in their economic roles. People in rural areas filled urban quotas for agricultural produce whilst maintaining enough for their own livelihood. A system of life employment, rationing and state welfare entitlements remained essential to urban living. Entitlement to the 'urban rationing regime' was conditioned on a resident having a local, non-agricultural, urban hukou. Entitlement to this hukou was determined by the local police bureau within the 1958 Hukou Registration Regulations and hukou transfer quotas stipulated by the central planners (not to be above $1.5 \%$ of the urban population per year). The 'urban rationing regime' presented the main obstacle to rural people living in urban areas. The huji institution administered a number of planned migrations but 'outside the plan' migration remained low (non-hukou migration; see chapter 3). The 1958 regulations were enforced by the ministry of public security, urban bureaucracies and the People's Police.

From the late 1970s non-compliance with the 1958 Hukou Registration Regulations was becoming more common. Years of almost total obstruction of rural to urban migration and the exclusion of agricultural hukou holders from non-agricultural employment had created increasing non-compliance with the regulations. But from 1978, urbanisation increased (see figure 7) and the primary sector labour force dropped from accounting for over $70 \%$ of the total labour force in 1978 to just over $60 \%$ in 1985 (see figure 8). The floating population grew from 2 million in 1980 to 20 million in 1985 when the temporary residency permit regulation appeared. ${ }^{374}$ By 1985 the rapid expansion in

\footnotetext{
${ }^{374}$ National Bureau of Statistics of China Department of Population and Employment 国家统计局人口就 业司. 《2005 中国人口》 [2005 China Population]. 北京 [Beijing]: 中国统计出版社 [China Statistics Press], 2006.
} 
agricultural production that appeared after the introduction of the HRS had been surpassed in national contribution to GDP by the tertiary sector (see figure 9).

Figure 7: Rural Urban Populations 1978 - 1985 (millions)

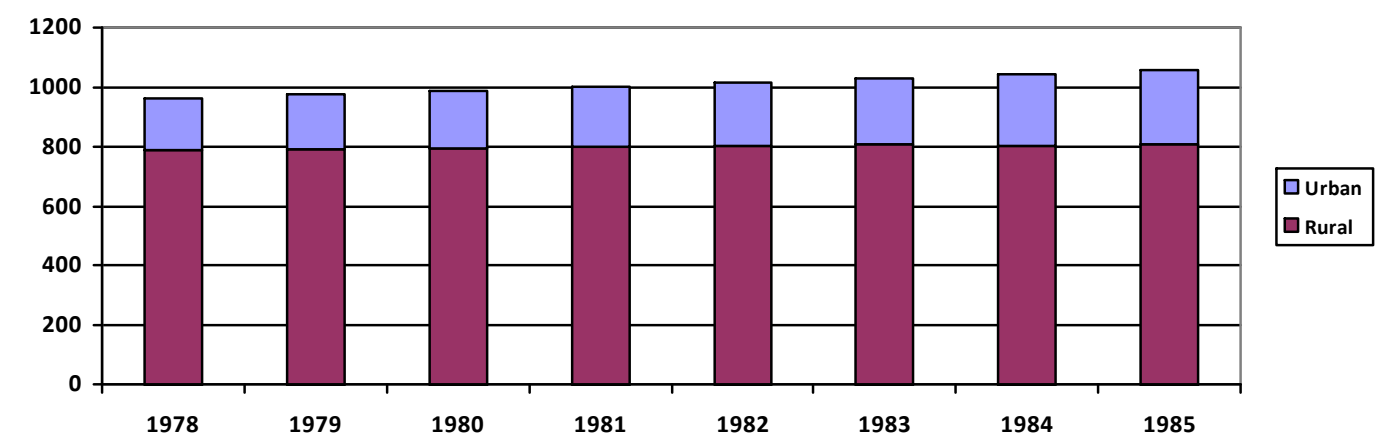

Source: China Population and Employment Statistics Yearbook 2008, p.5 $5^{375}$

Figure 8: Employed Persons by Three Strata Industries 1978-1985

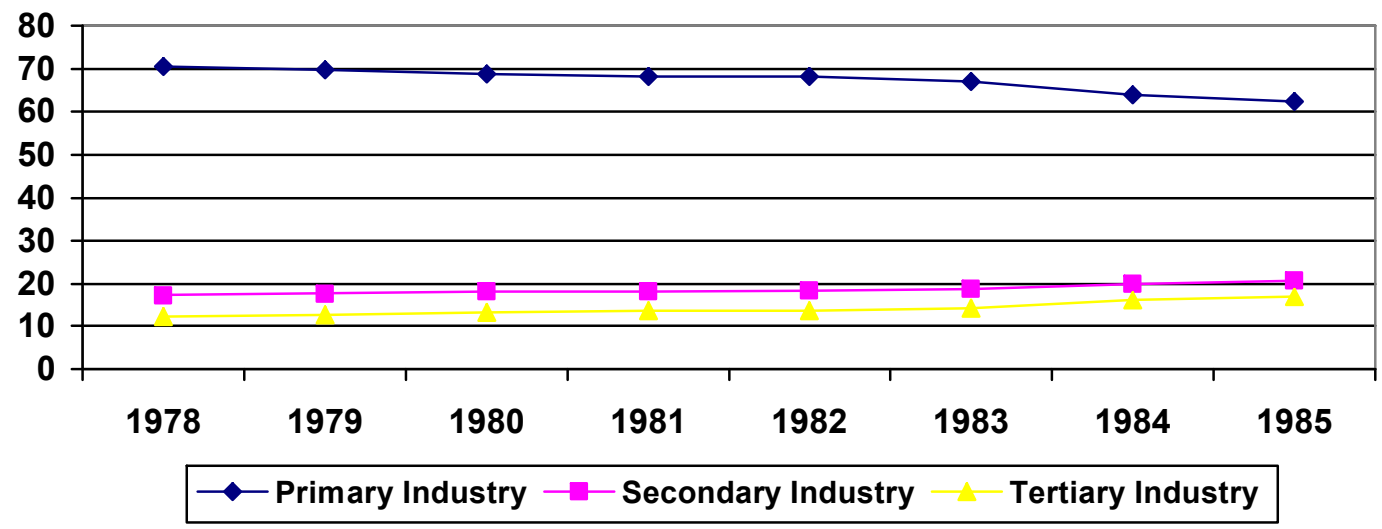

Source: China Population and Employment Statistics Yearbook 2008, p.18

Figure 9: Gross Domestic Product by Three Strata Industries 1978-1985 (\%)

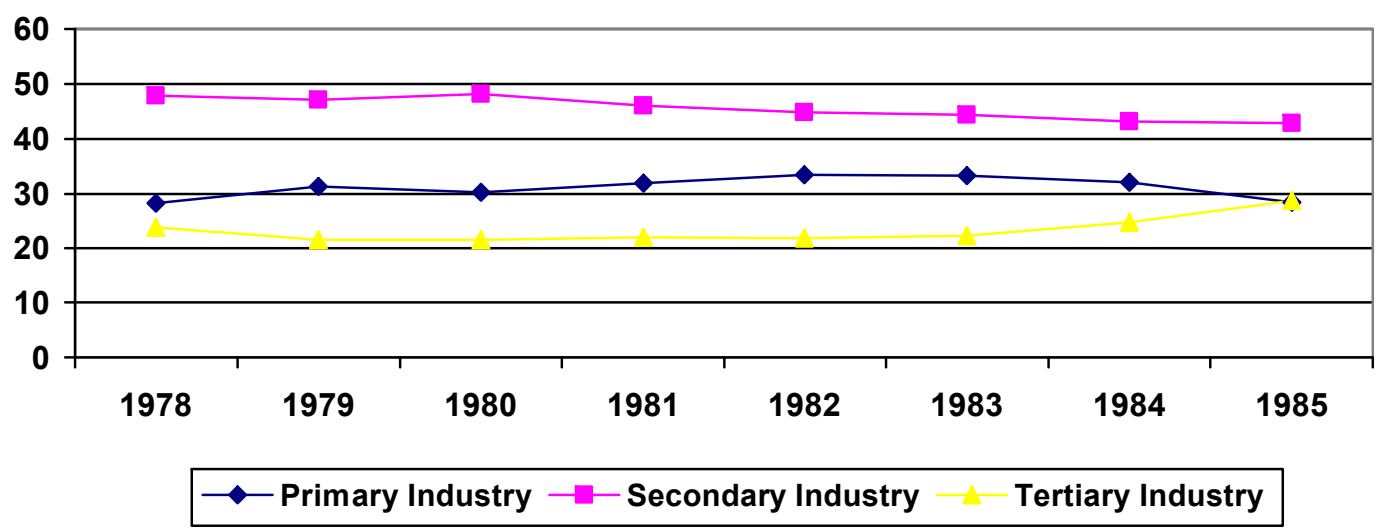

Source: China Population and Employment Statistics Yearbook 2008, p.33

\footnotetext{
${ }^{375}$ National Bureau of Statistics of China Department of Population and Employment Statistics 国家统计 局人口和就业统计司, ed. 《中国人口和就业统计年鉴 2008》[2008 China Population and Employment Statistics Yearbook]. 北京 [Beijing]: 中国统计出版社 [China Statistics Press], 2008.
} 
By 1985 it had already become apparent that China's economic reforms were increasingly unleashing supply and demand forces that were not being met by the planned labour migrations of the state. 'Outside the plan' migration, employment and housing in urban areas by agricultural hukou holders were becoming increasingly common. However, the majority of China's newest non-agricultural labour force neither qualified for nongzhuanfei (transfer of agricultural to non-agricultural hukou) nor hukou transfer to the permanent urban area they resided in. The fundamental objective of the huji institution had been to accelerate economic development through the planned allocation of China's labour force. This was managed through hukou transfer, but now increasing non-compliance was threatening the effectiveness of the entire institution. The advent of 'outside the plan' migration was at first responded to harshly by local public security authorities but eventually a decision to allow agricultural hukou holders to live in urban areas and be employed legally in non-agricultural employment was taken by the central authorities. This is one of the key reforms contributing to the rapid growth of China's secondary and tertiary industries.

Following a 1984 CPC directive, ${ }^{376}$ the Ministry of Public Security (MPS) issued one of the most significant directives of the reform era. Provisional Regulations Regarding the Management of Temporary Residents in Cities and Towns ${ }^{377}$ confirmed a Chinese citizen's legal right to reside for long periods of time in areas outside of their permanent hukou residence. The rationale for introducing this radical departure from the 1958 regulations was to adapt to the new economic and migratory conditions.

"The movement of people between regions and between rural and urban areas has been increasing in conjunction with China's economic restructuring and opening to the outside world, with the carrying out of the policy of revitalizing the domestic economy, and with the rapid development of commodity production and increasing commodity circulation. In order to adapt to these developmental requirements, to facilitate public life, to safeguard the legitimate

376 《中共中央关于一九八四年农村工作的通知》.
377 《关于城镇暂住人口管理暂行规定》. 
interests of the temporary population and to maintain social order, the following temporary regulations for the management of the temporary population in cities and towns are issued. ${ }^{378}$

The regulation stipulated that in order to improve the management of the 'temporary' population in urban areas any person over 16 years of age residing and/or working for more than three months in an urban area where they are not a permanent resident must apply for a 'temporary residence permit'. ${ }^{379}$ This would grant them legal temporary status in the urban area, allowing them to work, rent accommodation and reside in the city legally. The regulation also stipulated that those without the temporary permit should be dealt with strictly, being barred from renting a place to live and returned to their place of permanent hukou residence in accordance with the 1958 and 1977 regulations. Regulations such as registration of all guests at hotels and strict punishment of harbouring criminals or non-registered people were maintained in accordance with the 1958 regulations. However, the requirement for those staying over 3 months to reapply for temporary residency or return to their place of residence was significantly diverted from. The 1985 regulations introduced a renewable temporary residency permit for the purpose of residency and employment of rural workers in urban areas. In the author's opinion it remains the most significant change to the huji institution during the entire period of study because it made it legal for people with non-agricultural and/or non-local hukou to work and reside in urban areas and freed up labour mobility stimulating China's economic development. This regulation allowed the transfer of the labour force with 'agricultural hukou' from agricultural employment to non-agricultural employment. This was a necessary condition for the growth of the then nascent socialist market economy. At the same time public security officials were provided with new tools to re-gain governance of the floating population.

\footnotetext{
378 Provisional Regulations Regarding the Management of Temporary Residents in Cities and Towns 《关于城镇暂住人口管理暂行规定》.

${ }^{379}$ There were two types of temporary residence: employment《暂住证》and visiting 《寄住证》.
} 
Temporary migrants were prevented from participating in the 'urban rationing regime' but allowed to participate at the lower end of the new socio-economic structure. Thus, the early reforms accommodated 'temporary' migration unleashing the surplus labour force for economic development whilst concurrently increasing governance of the new socio-economic group. Enforcers of the huji institution still maintained strict control over nongzhuanfei except in market towns where there was some liberalisation of hukou transfer for some people. This gave cities a new relatively cheap labour force without increasing local government financial burdens by increasing the number of registered permanent urban hukou holders. ${ }^{380}$ The government also introduced a variety of residency schemes to encourage rural migrants to settle in low density urban areas. ${ }^{381}$ These reforms would become a potent recipe for rapid economic development, increased 'temporary' migration and rapid change in urban areas throughout the remainder of the period of study.

\subsubsection{Post-1985 Labour Transfer}

Post-1985 the prevalence of agricultural and/or non-local hukou holders involved in non-agricultural work became increasingly common. The rate of urbanisation steadily increased as more and more agricultural hukou holders began either working seasonally in urban areas or living there long term whilst someone else maintained the family plot. As urbanisation increased the number of local rural residents overtaken by 'urban sprawl' also increased. Nongzhuanfei and hukou transfer quotas remained extremely low. This meant there were now four huji institution categories of workers in urban areas (see table 5).

\footnotetext{
${ }^{380}$ Temporary permit holders were not accorded urban rights such as healthcare, education, social security, rationing or access to some employment.

${ }^{381}$ Following the national strategy of 'urbanisation from below'.
} 
Table 5: Four Categories of Urban Workers

\begin{tabular}{|l|l|l|}
\hline & Agricultural & Non-agricultural \\
\hline Local & $\begin{array}{l}\text { Local nongmin swept up in the 'urban } \\
\text { sprawl }\end{array}$ & The permanent population \\
\hline Non-local & Temporary workers from rural areas & Temporary workers from other urban areas \\
\hline
\end{tabular}

Previous to the 1985 reforms, the only category of 'legal' urban worker in any urban locale was the non-agricultural local population. The 1985 reforms increased the makeup of the urban labour market by allowing agricultural and non-local hukou holders to work in the city. This significantly increased China's competitive advantage by providing state, collective, private and joint enterprise employers with access to China's surplus labour force. The 1985 reform also ensured that the cities would not be flooded by rural labourers by maintaining the rural/urban and local/non-local divisions. Migrants were allowed to work but not allowed to reside permanently in urban areas. City governments could now control not only the permanent urban population through hukou transfer and nongzhuanfei but also to some extent the makeup and size of the temporary population through the new temporary permit system managed by local authorities

'Deng Xiaoping's Southern Tour' ${ }^{382}$ in 1992 gave official approval to the market reforms and increasing prevalence of rural labourers in urban employment. The growth of the temporary population was again encouraged when in 1992 the MPS issued regulations creating an urban hukou, ${ }^{383}$ for nongmin wanting to settle in excess of the national planned quota in targeted small cities and towns, special economic zones, economic open zones and high technology manufacturing open zones. ${ }^{384}$ This sped up urbanisation and the development of markets in these areas. The growth of urban

\footnotetext{
382 邓小平南巡.

383 城镇户口.

${ }^{384}$ Shenzhen Industry Information Website 深圳企业信息网. 《中国户籍管理制度的变迁》[Changes in China's Huji Management System]. 深圳企业信息网 [Shenzhen Industry Information Website], $<$ http://www.smers.com.cn/site49/news 643.htm>.
} 
markets alongside the planned economy provided rural migrants and local nonagricultural hukou holders a means of participating in the urban economy. This was almost exclusively as workers in poorly paid and unpopular non-agricultural urban employment.

Before the 1990s the distinction between temporary and permanent hukou status in urban areas had been upheld by the huji institution and the positive discrimination it policed through the 'urban rationing regime'. This was severely undermined as price fixing and rationing was slowly abolished in urban areas in the late 1980s and early 1990s. ${ }^{385}$ Further reforms throughout the 1990s meant permanent urban residents could no longer depend upon the state for lifetime employment and housing. This brought the permanent urban population more in-line with the stark economic conditions temporary and self-supporting grain hukou migrants live under and further stimulated economic growth. ${ }^{386}$ These policies led to mass transfer of China's rural labour force into tertiary and secondary employment over the period of study (see figure 10).

Figure 10: Employed Persons by Three Strata Industries 1978-2007 (\%)

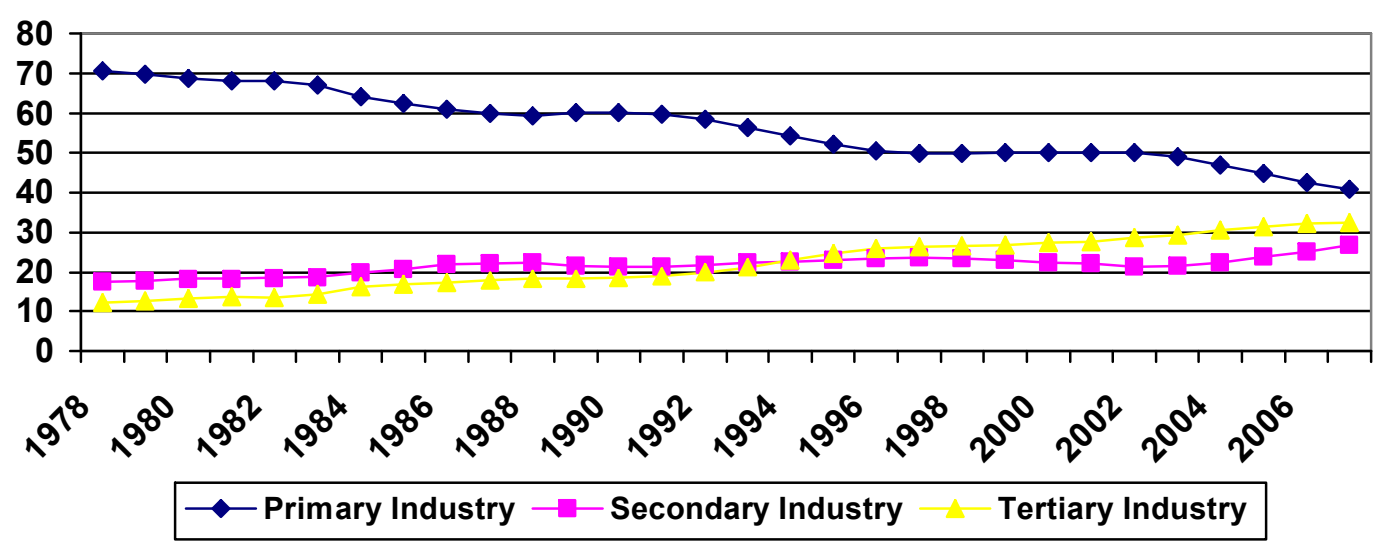

Source: China Population and Employment Statistics Yearbook 2008, p.18

\footnotetext{
${ }^{385}$ Grain rationing ceased in most parts of China in 1992.

${ }^{386}$ Whilst these politico-economic reforms decreased the positive discrimination that locals had come accustomed to under the planned economy some significant forms of positive discrimination remained, such as, access to certain types of employment, access to health care and insurance and access to education as well as entrenched socio-economic positive discrimination.
} 
The percentage of people employed in the primary sector dropped from $70 \%$ in 1978 to an all time low of just over $40 \%$ in 2007 . The percentage of employed persons in the secondary and tertiary sectors grew from nearly $30 \%$ in 1978 to just below $60 \%$ in 2007 . Employment in the secondary sector grew from $17 \%$ to $27 \%$. The tertiary sector recorded the biggest growth in its proportion of the working population, growing from a mere $12.2 \%$ in 1978 to $32.4 \%$ in 2007 . By 1994 the tertiary sector employed more people than the secondary. By 1997, secondary and tertiary industry combined employed more people than primary industry. By 2007, the primary sector still employed the most people of the three sectors suggesting labour transfer will continue for some time to come. Figure 11 illustrates real growth in employment in each sector.

Figure 11: Employed Persons by Three Strata Industries 1978-2007 (millions)

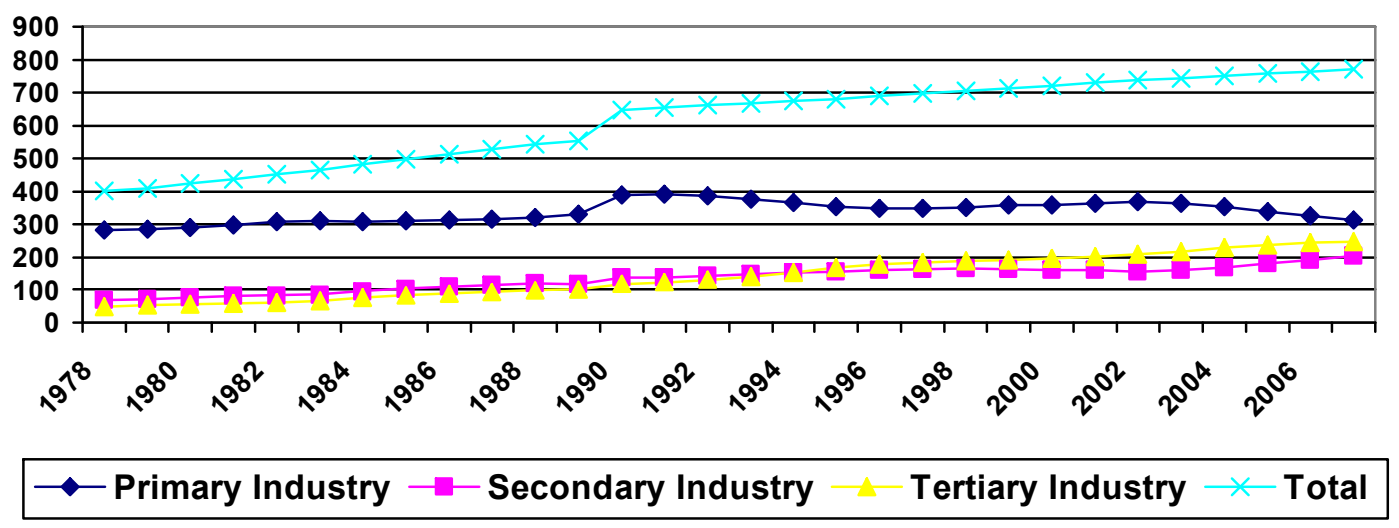

Source: China Population and Employment Statistics Yearbook 2008, p.18

Figure 11 shows total employment in China has grown from 402 million in 1978 to 770 million in 2007 . The fact that only $42 \%$ of the total population were employed in 1978 whilst 58\% were employed in 2007 suggests that significant underemployment was prevalent prior to reform. ${ }^{387}$ The growth in employed persons has come almost exclusively through growth in the secondary and tertiary sectors. Agriculture in 2007 employed almost the same amount of people as it did in the early 1980s. In 1978 there were 283 million agricultural workers. This rose to a high of 391 million in 1991 and

${ }^{387}$ 1978: 402/963 million $=42 \% ; 2007: 770 / 1321$ million $=58 \%$. 
then dropped 77 million to resettle at 314 million in 2007. The secondary industry steadily increased from 69 million workers in 1978 to 206 million in 2007. The temporary sector jumped from 49 to 249 million. In real terms, China now has 368 million more employed people than it did in 1978, a growth of 31 million in primary industry (8\%), 137 million in secondary industry (38\%) and 200 million in tertiary industry (54\%). The growth in numbers employed in these sectors comes from both natural population growth in urban areas and the inclusion of the traditionally excluded agricultural population in urban employment (see figure 12).

Figure 12: Employed Persons in Rural and Urban Areas 1978-2007 (\%)

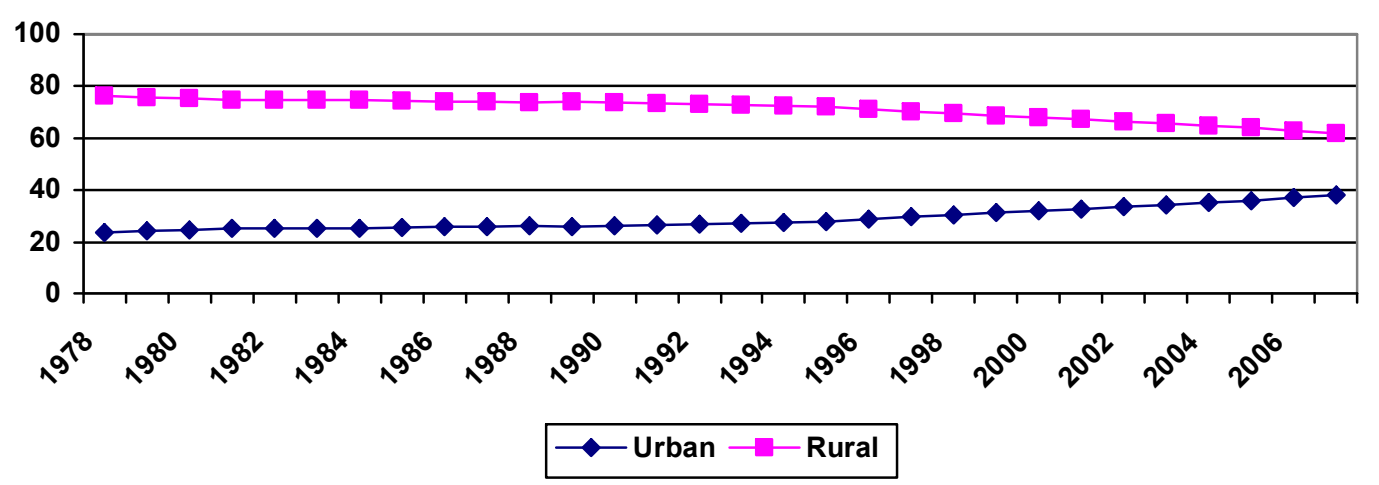

Source: China Population and Employment Statistics Yearbook 2008, p.17

The number of people employed in rural areas as a percentage of the national total has dropped from $76 \%$ in 1978 to $62 \%$ in 2007 . Over this period the number of employed people in rural areas actually grew from 306 million to 476 million, a growth of 170 million. The percentage of employed people in urban areas has increased from $24 \%$ in 1978 to $38 \%$ in 2007 . Over this period the number of employed people in urban areas grew from 95 million to 293 million, a growth of nearly 200 million. This 'transfer' of labour from the primary sector contributed significantly to the growth in secondary and tertiary industries. These industries have increasingly played a more significant role in the makeup of China's GDP (see figure 13). 
Figure 13: GDP by Three Strata Industries 1978-2007 (\%)

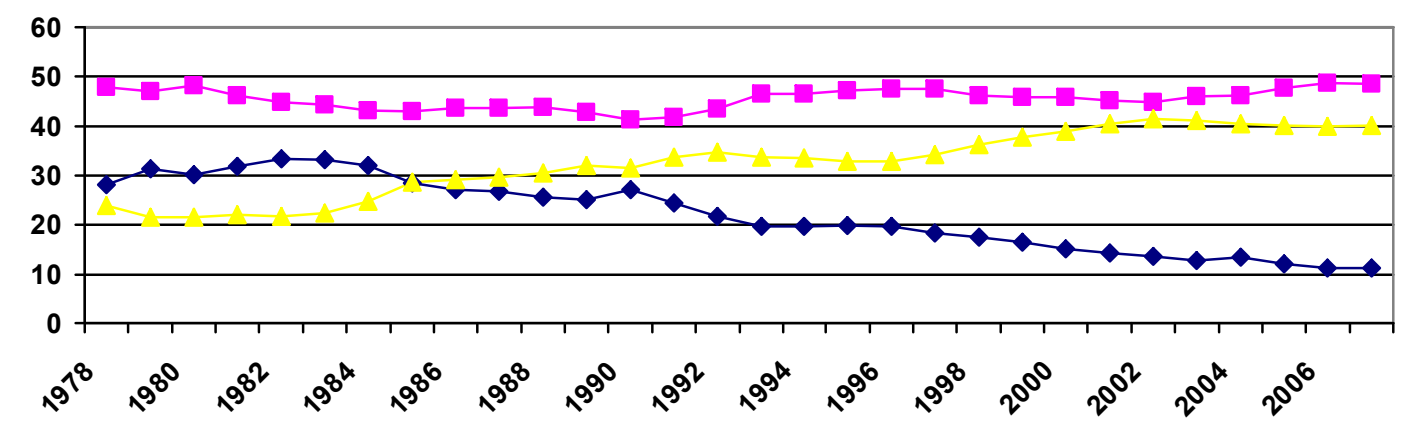

$\bullet-$ Primary Industry -- Secondary Industry - Tertiary Industry

Source: China Population and Employment Statistics Yearbook 2008, p.33

Figure 13 shows the decreasing importance of agriculture to China's GDP. After an initial rise in its contribution to GDP in the early reform era, accounting for a high of $33.4 \%$ in 1982 , agriculture has incrementally fallen to a low of $11.3 \%$ in 2007 . China's secondary industry has remained relatively consistent starting out above $45 \%$, dropping slightly throughout the 1990s and regaining to account for over 48\% of GDP in 2007. Accounting for just over $20 \%$ of GDP in the early reform era steady increases now show China's tertiary sector accounting for around 40\% of China's GDP. China's economy has grown in all three major industries but the growth has been particularly acute in secondary and tertiary industries.

Table 6: GDP Growth in Three Strata Industries (Yuan, 2008 prices)

\begin{tabular}{|l|l|l|l|}
\hline & 1978 & 2007 & Growth factor \\
\hline Primary & 102.8 billion & 2.8 trillion & 27 times \\
\hline Secondary & 174.5 billion & 12 trillion & 70 times \\
\hline Tertiary & 87.3 billion & 10 trillion & 115 times \\
\hline Total & 364.5 billion & 25 trillion & 68 times \\
\hline
\end{tabular}

Source: China Population and Employment Statistics Yearbook 2008, p.33

As China's population growth has not kept pace with this economic transformation GDP/capita has grown from 381 Yuan in 1978 to 18,934 Yuan in 2007, an increase of nearly 50 fold. This growth has been made possible by the controlled transfer of labour from the primary sector. The transfer of the agricultural labour force into the tertiary and secondary sectors (both in urban and rural areas) has created the conditions for 
China's secondary and tertiary sectors to emerge as the engines of China's domestic growth. This growth is leading to a 'great convergence' with the developed economies of the world as China moves away from its low base and economic growth rates increasingly translate into internationally spectacular GDP. ${ }^{388}$ In 1978 China's GDP was a mere $13 \%$ the size of US GDP (PPPs). By 1987 this had grown to $26 \%$ and by 1997 it was $46 \%$. By 2006 Chinese GDP was equivalent to a staggering $76 \%$ of US GDP (see figure 14). ${ }^{389}$ China has maintained an average of $10 \%$ annual growth over the period of study. It has grown faster than Japan, Germany, the US and India over the same period (see figure 15).

Figure 14: GDP, 2008 international dollars (PPPs) (trillions; 1978-2006)

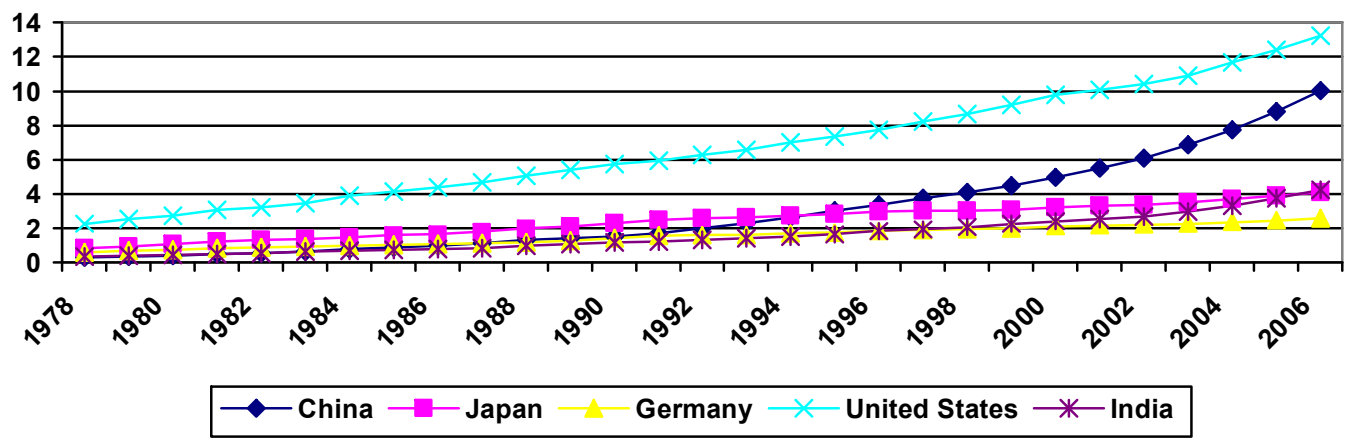

Source: United Nations/World Bank (2008) ${ }^{390}$

Figure 15: GDP Annual Rate of Growth (\%; 1978-2006)

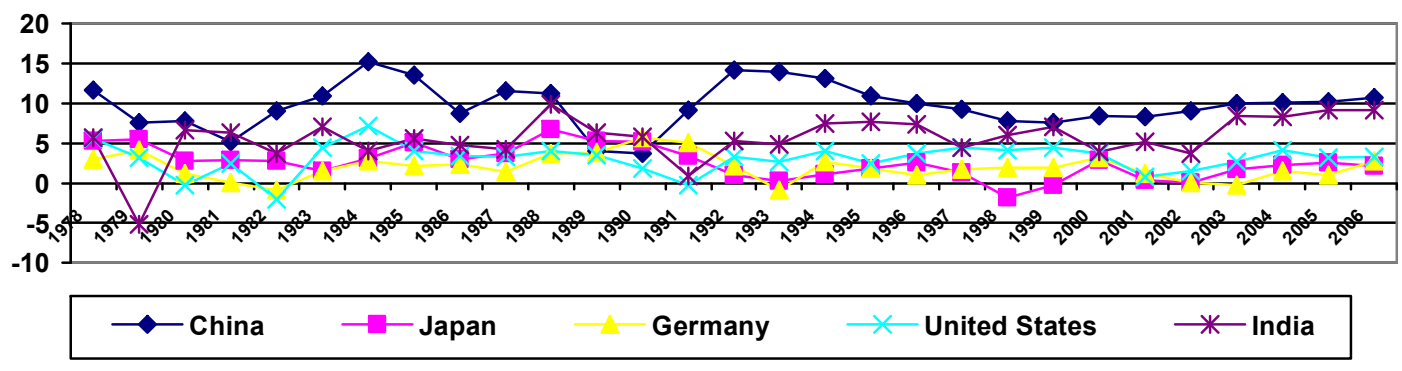

Source: United Nations/World Bank (2008) ${ }^{391}$

${ }^{388}$ The 'great convergence' is a play on Kenneth Pomeranz's title 'The Great Divergence' which describes the exceptional sustained industrial growth of Northwest Europe compared to East Asia in the $19^{\text {th }}$ century. See: Kenneth Pomeranz, The Great Divergence: China, Europe, and the Making of the Modern World Economy (Princeton: Princeton University Press, 2000).

${ }^{389}$ Chinese GDP as a percentage of US GDP (USD): 6.5\% (1978), 5.7\% (1987), $11.5 \%$ (1997) and 20\% (2006). See: UNdata: a World of Information, "Gdp at Market Prices, Current Us\$ (Wb Estimates)," United Nations Statistics Division.

${ }^{390}$ UNdata: a world of information, "Gdp in Current International Dollars (Ppps) (Wb Estimates)," United Nations statistics Division.

391 _ 
In summary, the MPS, local cadre and public security officials have successfully adapted the huji institution to accelerate economic development in the new socioeconomic environment. This has involved moving away from the use of the huji institution to control both supply and demand forces in the national labour market and strict division of urban and rural roles to a system that facilitates labour migration and labour transfer deemed in the interests of the socialist market economy. Whilst considerable liberalisation of the system is evidenced in the creation of the temporary residency permit it would be a mistake to assume the overall trend is liberalisation of the huji institution. These moves actually improved the state's ability to accelerate economic development and therefore can be seen as a strengthening of the huji institution. As the next section will show, the huji institution's objective to maintain social stability has also significantly strengthened over the period of study.

\subsection{Maintaining Social Stability}

A fundamental objective of the huji institution is to maintain social stability. Prior to 1985 the 1958 hukou regulations and central government quotas were used to regulate huji management. Authorities were urged to be vigilant in their control of both migration/movement and settlement from rural to urban areas and to maintain the huji registers central to public administration, police work and overall management of the population. In 1977 two regulations issued by the MPS and endorsed by the State Council appeared. These two regulations are significant for two reasons. Firstly, they strengthened the 1958 hukou regulations reaffirming their primary goals and function. Secondly, they imply the problem of non-compliance was becoming significant before the package of reforms that restructured the Chinese economy had been promulgated in late 1978. The Ministry of Public Security Regulations Regarding the Management of Hukou Transfer sends a clear message to local authorities to re-affirm the 1958 hukou regulations: 
"At present, there are a reasonable number of lazy and idle personnel without hukou in every city and town in China that urgently needs to be addressed. They should all return to the rural areas. All areas under the unified leadership of the Party Committee should adhere to the plan and after careful consideration adopt measures to mobilise these people to return home in a planned way over the next few years. Rural collectives should welcome them back to the rural areas to participate in agricultural production and provide them with rations, labour and other planning arrangements. 392

The nature and tone of these regulations show central and local authorities were still trying to maintain strict control and planning of both migration and settlement and to stamp out 'outside the plan' migrations. From this time on, the Chinese economy changed dramatically and migration and urbanisation trends grew both within and outside the plan, though by the far the latter, changing the makeup of the labour force dramatically. With both urban and rural residents increasingly mobile, public security authorities adapted the huji institution to meet the new security environment. By the mid-1980s urban police efforts to strictly control the 'floating population' had been replaced by limited accommodation and efforts to increase governance and surveillance over it as well as efforts to strengthen and nationalise permanent hukou procedures, especially hukou transfer. By 2007, the MPS had successfully reformed huji management at the local level by increasing governance of both the temporary and permanent population and by nationalising and modernising huji record collection.

\subsubsection{Governing the Temporary Population}

The traditional means of managing and maintaining governance and surveillance of the population became ineffective very quickly during the early 1980s. This was due to non-compliance through increased 'outside the plan' population mobility and increasing employment of agricultural hukou holders in non-agricultural employment. There was no provision for this in the 1958 Hukou Registration Regulations. Three important regulatory reforms occurred over the reform era to strengthen governance over the

${ }^{392}$ Recommendations Regarding Earnestly Carrying Out State Council Notification of 'The Ministry of Public Security Regulations Regarding the Management of Hukou Transfer' 《关于认真贯彻〈国务院 批转"公安部关于处理户口迁移的规定"的通知〉的意见》 1977. 
temporary population. The first introduced a compulsory Temporary Residency Permit in 1985. The second introduced a compulsory Temporary Identity Card in 1989. The third strengthened the governance of the Temporary Residency Permit in 1995. These efforts strengthened local government control of the floating population.

Management of Temporary Residents in Cities and Towns was enacted by the MPS in 1985 'to improve the management of the 'temporary' population in urban areas'. ${ }^{393}$ The previous section showed how this regulation gave local governments a tool to manage the transfer of labour from the primary sector and this promoted economic development. This directive also strengthened the ability of public security officials to perform population registration, surveillance and management, maintain social stability and control urbanisation. The regulation stipulated that any person over 16 years of age residing and/or working for more than three months in an urban area where they are not a permanent resident must apply for a 'temporary residence permit'. This permit gave the local security officials the regulatory power to monitor the temporary population and deal strictly with non-registered 'floaters'. It also gave them some degree of influence over the makeup of the temporary population through their ability to approve or deny temporary permits. The MPS and the central authorities issued the directive to provide temporary residence permits to rural hukou holders working and residing in urban areas in order to strengthen their governance and surveillance of the new temporary population.

By 1988 temporary migration had reached 50 million. ${ }^{394}$ In 1989 the MPS issued Interim Provisions for Management of Temporary Identification Permits. ${ }^{395}$ This

\footnotetext{
${ }^{393}$ Provisional Regulations Regarding the Management of Temporary Residents in Cities and Towns 《关于城镇暂住人口管理暂行规定》.

${ }^{394}$ National Bureau of Statistics of China Department of Population and Employment 国家统计局人口就 业司. 《2005 中国人口》[2005 China Population].
} 
provision provided the necessary supplement to the 1985 Identity Card regulations and regulated that people residing outside of their place of permanent hukou residence should apply for a temporary identity card valid for two years as a supplement to their standard identity card. These permits were to be managed by local authorities in conjunction with hukou registration organs and a migrant needed to have official documents from both their place of temporary residence and their place of permanent hukou residence to apply. Temporary migrants were required to carry this proof when 'emigrating'.

The MPS rationale for the new permit was, “...to improve the system of resident identity cards, to strengthen population management and to maintain social order. ${ }^{\text {} 396}$ Phenomenal growth of the labour market, in particular mass gains in employment opportunities in the service sector, meant public security officials were increasingly dealing with people holding 'non-local' hukou and identity cards. The 1989 temporary identification provisions further increased the tools police and local officials had to manage the temporary population and to send non-complying migrants back to their place of permanent residence. Also in 1989, the State Council issued a further directive calling for greater control over the floating population and increased efforts to manage the increasing labour mobility. ${ }^{397}$ These measures were part of the government's concerted effort over the reform era to strengthen their governance of the temporary population in urban areas.

\footnotetext{
395 《临时身份证管理暂行规定》.

${ }^{396}$ Interim Provisions for Management of Temporary Identification Permits 《临时身份证管理暂行规 定》.

${ }^{397}$ Notification Regarding Strictly Controlling Overly Rapid Increase in 'Nongzhuanfei'《关于严格控制 “农转非” 过快增长的通知》.
} 
By 1995 the floating population had reached 80 million. ${ }^{398}$ That year the MPS issued Application Procedures for Temporary Residency Permits to “...strengthen management of the floating population, safeguard citizens' lawful rights and interests and maintain public security and social order in accordance with the PRC Hukou Registration Regulations and related regulations." ${ }^{399}$ The directive stated the Temporary Residency Permit (introduced 1985) was proof of 'temporary residence' in an area outside a resident's permanent hukou location, a status different to the 1958 definition of 'temporary residence'. ${ }^{400}$ The 'temporary population' were instructed to apply for the permit when 'notifying the local security bureau of their temporary hukou status in the area, ${ }^{401}$ and to use the Temporary Residency Permit when applying for work permits, ${ }^{402}$ business permits, ${ }^{403}$ and other permits in their 'temporary destination'. Work units and employers were required to declare the temporary hukou status of their employees to local authorities and to ensure they applied for a Temporary Residency Permit. The regulation strictly forbids employers hiring migrants that do not have a Temporary Residency Permit.

The directive outlined three ways to apply for a Temporary Residency Permit: by applying through the hukou register of the head of a local residency; by the government work unit or the employer registering employment details; or by providing a property lease. Permits were valid for a year but renewable. Penalties were applied for noncompliance, fraud or confiscation of permits by employers. Temporary Residency

\footnotetext{
${ }^{398}$ National Bureau of Statistics of China Department of Population and Employment 国家统计局人口就 业司. 《2005 中国人口》[2005 China Population].

399 Application Procedures for Temporary Residency Permits 《暂住证申领办法》 1995.

${ }^{400}$ People visiting family and friends, on holiday or on a business trip were not to apply for a Temporary Residency Permit but were required, as had been the case since 1958, to (申报暂住户口登记或者旅客登 记) 'register their temporary hukou status or have it registered by the hotel they are staying.' During fieldwork in Beijing in 2008, I witnessed a hotel owner being reminded by local police officials of his duty to register his guests with the local police station.

401 申报暂住户口登记.

402 劳务许可证.

403 工商营业执照.
} 
Permit holders caught breaking the law could have their Temporary Residency Permit withdrawn according to the severity of the circumstances. Local security officials gained access to important information including name, sex, date of birth, permanent hukou location, resident identity card number, temporary address, reason for temporary residence and date of expiry. This information was an important resource for local and central public security officials and greatly aided them to increase governance over this new socio-economic group. Table 7 sets out five special regulations for the population holding a Temporary Residency Permit:

Table 7: MPS Temporary Resident Regulations

\begin{tabular}{|c|c|}
\hline 1. & Abide by national laws and regulations; \\
\hline 2. & $\begin{array}{l}\text { Declare temporary hukou status and apply for a Temporary Residency Permit as } \\
\text { required by law; }\end{array}$ \\
\hline 3. & $\begin{array}{l}\text { Actively show your Temporary Residency Permit if inspection is required, do not } \\
\text { resist; }\end{array}$ \\
\hline & $\begin{array}{l}\text { It is not permitted to use a fake Temporary Residency Permit or use another person's } \\
\text { Temporary Residency Permit; }\end{array}$ \\
\hline & $\begin{array}{l}\text { Cancel and hand in the Temporary Residency Permit at the local police station when } \\
\text { leaving the temporary residency. }\end{array}$ \\
\hline
\end{tabular}
Source: Application Procedures for Temporary Residency Permits ${ }^{404}$

These moves showed the MPS commitment to establishing management and control over the growing and mobile temporary population. Temporary Residency Permits and Temporary Identity Cards gave extraordinary powers to local officials, to not only have a record of both the permanent and temporary residency population in their area (as well as the standard short stay temporary population), but also the ability to manage the size and nature of the temporary residency population through the power to approve or decline applications and to punish and remove those infringing the regulations. As the following section shows, poor implementation of hukou policies plagued local government officials. As a response efforts to enhance the effectiveness of the huji institution as a system for maintaining social stability greatly increased over the 80 s and 90s. These efforts resulted in a strengthened huji institution that provided local officials

${ }^{404}$ Application Procedures for Temporary Residency Permits 《暂住证申领办法》1995. 
with tools to improve their governance of both the permanent and temporary populations in their locale.

\subsubsection{Permanent Hukou \& Hukou Transfer}

MPS and local authority efforts to increase governance of the temporary population were supplemented by efforts to strengthen the management of the permanent hukou population and to strengthen hukou transfer procedures. These moves represent a central government objective to universalize and standardise hukou procedures so as to improve public security officials' ability to maintain social order. They were part of overall efforts to strengthen police work in the face of rising crime rates which jumped from over 2 million in the 1990s to more than 4 million in 2000 and 4.75 million in 2007 (3.7 million theft, robbery and burglary). Figure 16 shows the growth in the crime rate per 100,000 people from 1981 to 2001 .

Figure 16: Crime Rate 1981 - 2001 (per 100,000 people)

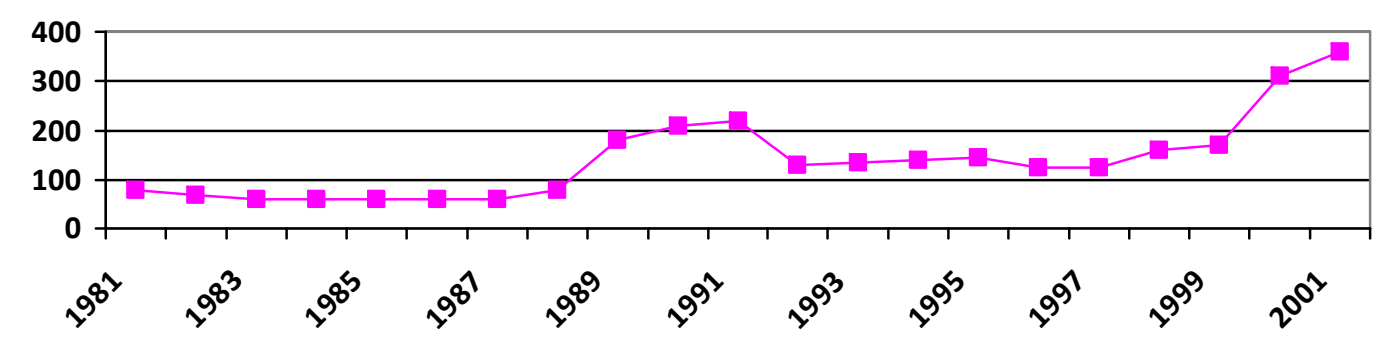

Source: Børge Bakken (2005) Comparative Perspectives on Crime in China, Fig 3.1, p.65

In 1985 the PRC Resident Identity Card Regulations were issued. ${ }^{406}$ This established the basis for a national identification card system that became codified into law in $2004 .^{407}$ Such a system became increasingly necessary as China's population grew and the direct role of the state in the economy decreased. The MPS experimented with the identity

\footnotetext{
${ }^{405}$ Børge Bakken, "Comparative Perspectives on Crime in China," in Crime, Punishment, and Policing in China, ed. Børge Bakken (Lanham: Rowman and Littlefield, 2005).

406 《中华人民共和国居民身份证条例》.

${ }^{407}$ PRC Resident Identity Card Law 《中华人民共和国居民身份证法》 2004.
} 
card system as an additional means of registering the permanent population and ensuring people in society used their nationally registered identity. ID cards did not replace the hukou system as their records remained based on hukou records and one's hukou book was necessary for any change of residency or migration. However, increasing use of the system meant ID cards soon replaced hukou books as the primary means of proving one's identity. ${ }^{408}$ The regulations in effect from 1985 to 2004 can be seen as a precursor to the law and a trial of a nationwide identification card system that has become increasingly sophisticated.

In 1989 a State Council directive called for greater control over the floating population and strict adherence to hukou transfer policies, particularly nongzhuanfei. ${ }^{409}$ This was followed in 1991 by a MPS directive addressing some of the new problematic trends in the management of hukou transfer in urban areas. These problems included: local areas establishing of their own accord obstructive regulations to legal hukou transfer and processing; slow processing times; poor service by the public security authorities; unclear application procedures not understood or conveyed to the general public; and illegal bribes. Local governments were instructed to address these concerns (see table 8).

Table 8: MPS Directives to Local Government

\begin{tabular}{|cl|}
\hline 1. & Create clean government \\
\hline 2. & Improve efficiency \\
\hline 3. & Follow the national laws and regulations on hukou transfer and processing \\
\hline 4. & Desist all local regulations that do not adhere to national regulations \\
\hline 5. & Deal harshly with bribes and other illegal behaviour \\
\hline 6. & Simplify procedures \\
\hline 7. & Increase transparency \\
\hline 8. & Improve public understanding of procedures \\
\hline 9. & Improve public service \\
\hline 10. & Improve the overall political quality of the police and cadres \\
\hline
\end{tabular}

Source: Notification Regarding Practically Resolving Difficulties the Masses Have Processing Hukou, 1991

\footnotetext{
${ }^{408}$ As mentioned previously, a temporary identity permit was established for the 'temporary population' in 1989.

409 《关于严格控制 “农转非”过快增长的通知》.
} 
"A small number of the police are not abiding by the regulations, are neglecting their duties, have a crude attitude, have low work efficiency and cause delay after delay in people's hukou applications. Some even go as far as to deliberately make things difficult for people by making hukou a bargaining chip for their own personal gain, breaking the law and disobeying their discipline. ${ }^{, 410}$

Shanghai regulations were held up as a model for other areas to follow. Consultation with other branches of the public security organs and decisions on questions of hukou transfer were to be dealt with within a certain timeframe. The public were to be treated fairly, according to the regulations and their legal rights were to be upheld. The Shanghai notification was an early attempt to unify hukou related tasks the 'huji police' were required to perform:

Table 9: Shanghai Public Security Bureau Hukou Related Tasks

\begin{tabular}{|ll|}
\hline 1. & Urban hukou transfer \\
\hline 2. & Adding 'newborn hukou' to 'mother's hukou' \\
\hline 3. & Applications for resident identification permits \\
\hline 4. & Hukou transfer of urban non-agricultural population with allocated housing \\
\hline 5. & Hukou transfer of urban non-agricultural population purchasing commercial housing \\
\hline 6. & $\begin{array}{l}\text { Declaration of proof of hukou for labouring, personnel and civil administration, with } \\
\text { hukou in this city }\end{array}$ \\
\hline 7. & Approval of hukou with other police stations \\
\hline 8. & Declaration of temporary hukou (暂 (寄) 住的户口 ) \\
\hline 9. & Declaration of temporary hukou for overseas compatriots, Hong Kong, Macao and \\
\hline 10. Taiwan compatriots \\
\hline 11. Cancellation of hukou for those enrolled in the military travelling overseas \\
\hline 12. Cancelation of hukou due to death \\
\hline 13. Cancelation of hukou for imprisonment, education through labour, youth education \\
\hline 14. Modification of hukou due to new developments \\
\hline 15. Other proper outward transfer of hukou \\
\hline Source Notification Regarding Practically Resolving Difficulties the Masses Have Processing
\end{tabular}

Source: Notification Regarding Practically Resolving Difficulties the Masses Have Processing Hukou, 1991

Despite these efforts at universalising hukou management and serious warnings against illegal hukou practices, sales of non-agricultural urban hukou by local government continued to be prevalent in many cities. This became enough of a national issue that the central authorities began issuing regulations at regular intervals directly prohibiting local governments selling non-agricultural urban hukou. The State Council issued, Notification Regarding Prevention of Public Sales of Urban Hukou by Some Cities [and]

\footnotetext{
${ }^{410}$ Notification Regarding Practically Resolving Difficulties the Masses Have Processing Hukou 《关于 切实解决群众办户口难问题的通知》 1991.
} 
Counties in $1988 .^{411}$ After outlining recent issues with local authorities selling urban hukou it strictly prohibited this practice. At least another three notifications banning this practice appeared in the following years, twice in 1992 and once in $1994 .^{412}$ In 1994 the Ministry of Public Security Notification Regarding Using New Hukou Relocation Certificate, [and] Hukou Permits for Resettlement further stamped uniformity on the management of hukou transfer. ${ }^{413}$ This was followed in the same year by a joint Notification Regarding Issues Relating to Hukou Transfer for Redeployed Cadres, [and] Labourers which again strictly condemned hukou sales and local government corruption and called for national uniformity in huji management. ${ }^{414}$ This was an early indication of the contemporary value of urban hukou and a cautionary tale of local government interest as well as a strong indication that central government intended to unify and standardise hukou management.

In 1995, the MPS further refined the information requirements for permanent urban hukou records. Notification Regarding Introducing New Permanent Population Registration Forms and Resident Hukou Registers put forward strict conditions on the contents and processing of permanent hukou records and outlined the categories of information required in a hukou record. ${ }^{415}$ Forms for registration of the permanent population, ${ }^{416}$ and Resident Hukou Registers, ${ }^{417}$ were to include 34 register items

\footnotetext{
411 《国务院办公厅关于制止一些市、县公开出卖城镇户口的通知 (国务院办公厅) 1998 年》.

${ }^{412}$ Ministry of Public Security Urgent Notification Regarding Resolving and Preventing the Flawed Method of Publicly Selling Non-Agricultural Hukou (1992) 《公安部关于坚决制止公开出卖非农业户 口错误做法的紧急通知 1992 年》; General Office of the Central Committee of the Communist Party of China [and] the General Office of the State Council Urgent Notice Regarding Immediate Cessation of Selling Non-Agricultural Hukou (1992) 《中共中央办公厅、国务院办公厅关于立即制止出卖非农业 户口的紧急通知 1992 年》; Ministry of Public Security, Ministry of Finance, [and] People's Bank of China Notification Regarding Resolving and Preventing the Continued Sale of Non-Agricultural Hukou (1994) 《公安部、财政部、中国人民银行关于坚决制止继续出卖非农业户口的通知 1994 年》。 413 《公安部关于启用新的户口迁移证、户口准迁证的通知》。

414 《公安部、人事部、劳动部关于干部、工人调动办理户口迁移手续有关问题的通知》.

415 《公安部关于启用新的常住人口登记表和居民户口簿有关事项的通知》.

416 常住人口登记表.

417 居民户口簿.
} 
ranging from ethnicity, date of birth and address to educational achievements, marital status and service for the government or military. It also included items directly relating to previous hukou status and reasons for migrating and transferring hukou. A list of 28 items was required for Resident Hukou Registers for Family Hukou ranging from the name of the head of the household to reasons for migrating and transferring hukou. ${ }^{418}$ These new requirements for careful and thorough categorization of permanent hukou registers were to be introduced universally by local governments by the year 2000 . Local governments were instructed to stridently uphold the existing hukou regulations. Finally, in 1998 the MPS issued a further regulation strengthening hukou management. Job Specification for Processing Hukou [and] Identity Cards for Residents further clarified and nationalised what central government expected from local police regarding huji management. ${ }^{419}$ These regulatory moves gave local authorities increased powers and greater access to detailed, nationalised and unified population records. This greatly aided public security work, such as controlling crime, the 'targeted population' and local government corruption in hukou transfer increasingly necessary in the new mobile and relatively criminal environment. These moves were further reinforced by increasing modernisation and sophistication of the huji system.

\subsubsection{Modernisation of Huji Management}

In 2004, the PRC Resident Identity Card Law came into effect. ${ }^{420}$ This had been passed the previous year by the Standing Committee of the $10^{\text {th }}$ National People's Congress. Whilst not directly changing the collection of regulations managing the huji institution, the Resident Identity Card Law did codify into law the requirement for all Chinese citizens to be registered with public security officials when previously this had only

\footnotetext{
418 家庭户的居民户口簿.

419 《办理户口、居民身份证工作规范》。

420 《中华人民共和国居民身份证法》。
} 
been a regulation. ${ }^{421}$ This law stipulates all citizens of the PRC over the age of 16 must apply for a resident identity card. The card contains standard information such as name, date of birth and sex, but also contains a citizens' 'permanent hukou location address' ${ }^{422}$ Identity cards and records are managed by the public security organs and State Council and are issued by public security officials at the county level in a 'resident's permanent hukou location'. ${ }^{423}$ When applying for the identity card, residents must provide their 'resident hukou register'. ${ }^{424}$ In 2005 , following the precedent set down by temporary identity regulations in the 1980 s, the PRC Temporary Resident Identity Card Management Measures were issued by the MPS. ${ }^{425}$ Unlike the Interim Provisions for Management of Temporary Identification Permits, requirements for 'temporary migrants' to carry a temporary identification card were abandoned. By this time increasing digitalisation and standardisation of temporary hukou permits had made temporary ID cards no longer essential to maintaining governance of the temporary urban population.

The nationalisation and standardisation of hukou management allowed the central authorities to complete a major modernisation of the huji system at the beginning of this century. In 1998 the MPS began computerising the huji system and in 2001 the national hukou information database was created as part of the 'Golden Shield' ${ }^{426}$ project that aimed to improve communication between police and crack down on possible dissent or opposition on the internet. ${ }^{427}$ According to the 'Chinese Communist Party Central

\footnotetext{
${ }^{421}$ The huji institution is administered by a collection of regulations and there are no national laws for huji management. The 1958 Hukou Registration Regulations are a good example of how these regulations can be as instrumental as a law but not subject to legislative approval or constitutional oversight. 422 常住户口所在地住址.

423 居民常住户口所在地.

424 居民户口簿.

425《中华人民共和国临时居民身份证管理办法》.

426 金盾.

${ }^{427}$ Research Directorate, "Issue Paper: China: Reforms of the Household Registration System (Hukou) (1998-2004)."
} 
Committee Commission for the Comprehensive Management of Social Security,' the Golden Shield project was launched to promote, “...the adoption of advanced information and communication technology to strengthen central police control, responsiveness, and crime combating capacity, so as to improve the efficiency and effectiveness of police work." ${ }^{228}$ This project was completed in 2004 and has greatly aided the work of the MPS and the ability of urban authorities and central government to manage China's population through the nationwide digital surveillance network.

"Old style censorship is being replaced with a massive, ubiquitous architecture of surveillance: the Golden Shield. Ultimately the aim is to integrate a gigantic online database with an all encompassing surveillance network - incorporating speech and face recognition, closed-circuit television, smart cards, credit records, and Internet surveillance technologies. ${ }^{, A 29}$

The modernisation of the huji institution has involved standardisation, nationalisation and increasing sophistication. National systems of surveillance are now amongst the best in the world involving the use of surveillance cameras, face recognition software, digitalised ID cards, internet identification and monitoring, and most significantly an integrated national database of huji records accessible at the local and national level. The movement, behaviour, employment, residence and hukou details of Chinese citizens are now available to public security officials at the touch of a button. The temporary address and employment details of temporary residents are displayed next to permanent residents via digital mapping technology that can be used to track, monitor and govern the entire Chinese population (see figure 17).

\footnotetext{
${ }^{428}$ Cited in: Greg Walton, "China's Golden Shield: Corporations and the Development of Surveillance Technology in the People's Republic of China," (Quebec: International Centre for Human Rights and Democratic Development, 2001).

${ }^{429}$ Ibid.
} 
Figure 17: Digitalised Huji Management - Location of the Non-Agricultural Population
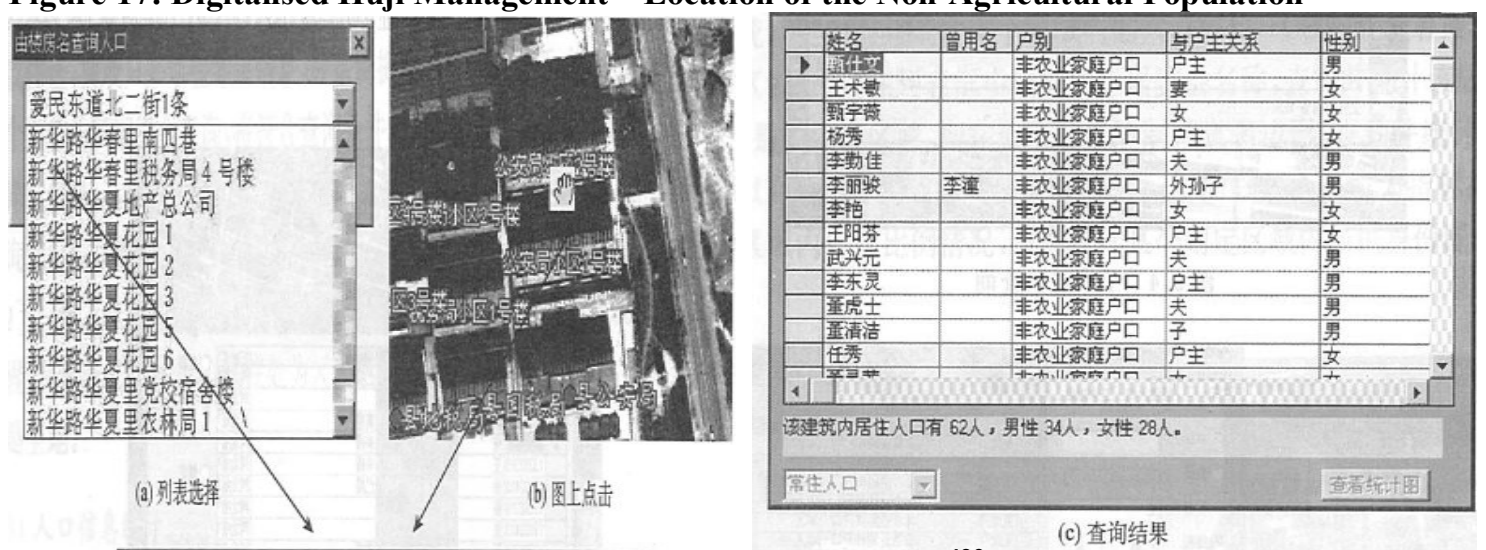

Source: Population and Geography Information Systems, p.175 ${ }^{430}$

Over the period of study the huji institution has been strengthened to provide a tool for local and central authorities to implement greater management, surveillance and governance of the population. This has been achieved through a variety of regulations aimed at the temporary and permanent populations and through standardisation of hukou transfer procedures. Earlier standardisation allowed the MPS to digitalise the system giving extraordinary powers to local and central authorities to use the huji institution to monitor and govern the Chinese populace. This is evidence of a strengthening of the primary huji institution objective to maintain social stability by adapting huji management to the changing security environment. In particular, authorities in urban areas have had to adapt to an increasingly mobile, rural and nonlocal population. Efforts to manage and restrict urbanisation and migration have also strengthened the ability of the People's Police to provide security in these areas.

\subsection{Managing \& Restricting Migration \& Urbanisation}

A 1977 state directive states increases in the size of the urban population must be planned and only occur where agricultural surpluses allow. ${ }^{431}$ It also states control of

\footnotetext{
${ }^{430}$ Li Chengming 李成名, Yin Hao 印浩, Wang Jizhou 王继周, and Jin Yimin 金逸民. 《人口地理信息 系统》[Population and Geography Information Systems], 地理信息系统理论与应用丛书 [Geography Information Systems Theory and Application Series]. 北京[Beijing]: 科学出版社 [Science Press], 2005. ${ }^{431}$ The Ministry of Public Security Regulations Regarding the Management of Hukou Transfer 《公安部 关于处理户口迁移的规定》 1977.
} 
migration, particularly rural to urban migration and associated agricultural to nonagricultural status, must be strict and in accordance with the 1958 regulations. The strict regulations particularly apply to those moving to denser populated regions, namely rural to urban, small town to city, small cities to medium sized cities and so on culminating in an almost blanket ban on hukou transfer and migration to Beijing, Shanghai and Tianjin in an effort to control the size of the population in heavily urbanised regions. It also states authorities should grant residency to those applicants with legitimate reasons wishing to transfer hukou from high density urban populations to low density urban populations or rural villages. Temporary work by rural residents in urban areas was especially singled out:

"Temporary workers, contract workers, rotation workers and workers engaged in both industrial and agricultural production who are recruited from the villages may not transfer their hukou to town or city. Rural hukou employees of collectives at the county or below county level may not become part of the 'grain eating population'. Workers in commune-run factories may not become part of the 'grain eating population'., ${ }^{432}$

This regulation directs local authorities to educate people about the 1958 regulations and find ways to return rural people to rural areas to control urbanisation. In 1977, further MPS recommendations appeared. ${ }^{433}$ These were, “...concrete regulation of internal 'nongzhuanfei' control guidelines, namely, the number of people migrating from rural areas to the city or town through 'nongzhuanfei' must not exceed $1.5 \%$ of the existing non-agricultural population." 434 These regulations provide the baseline for how the MPS used the huji institution to manage and restrict migration and urbanisation. Over the period of study this objective has remained but the way authorities have

\footnotetext{
432 The Ministry of Public Security Regulations Regarding the Management of Hukou Transfer 《公安部 关于处理户口迁移的规定》 1977 .

${ }^{433}$ Recommendations Regarding Earnestly Carrying Out State council Notification of 'The Ministry of Public Security Regulations Regarding the Management of Hukou Transfer 《关于认真贯彻〈国务院批 转"公安部关于处理户口迁移的规定"的通知〉的意见》 1977 .

${ }^{434}$ Shenzhen Industry Information Website 深圳企业信息网。《中国户籍管理制度的变迁》[Changes in China's Huji Management System].
} 
utilised the huji institution to obtain this objective has changed significantly in response to the new socio-economic environment and new economic imperatives.

\subsubsection{Pressures for Reform}

China's population growth has decreased significantly over the reform era dropping from periodic highs of $15 \%$ in the 1980 s to just over $5 \%$ in 2007 . This has largely been due to a falling birth rate. This has fallen from a high of $23 \%$ in 1987 to $12 \%$ in 2007 (see figure 18). China's population has grown from 962 million in 1978 to 1.3 billion in 2007 remaining the world's largest nation-state (see figure 19). Population density per square kilometre has risen from 100 to 138 people (see figure 20).

Figure 18: Birth, Death \& Natural Growth Rate 1978-2007

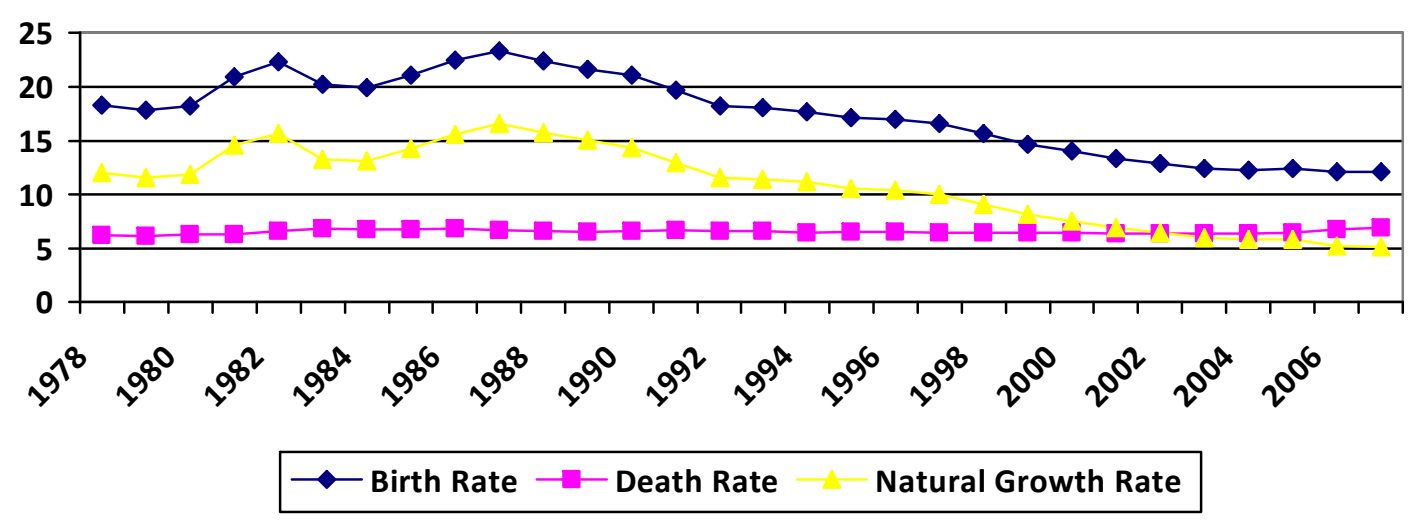

Source: China Population and Employment Statistics Yearbook 2008, p.6

Figure 19: National Population 1978-2007 (millions)

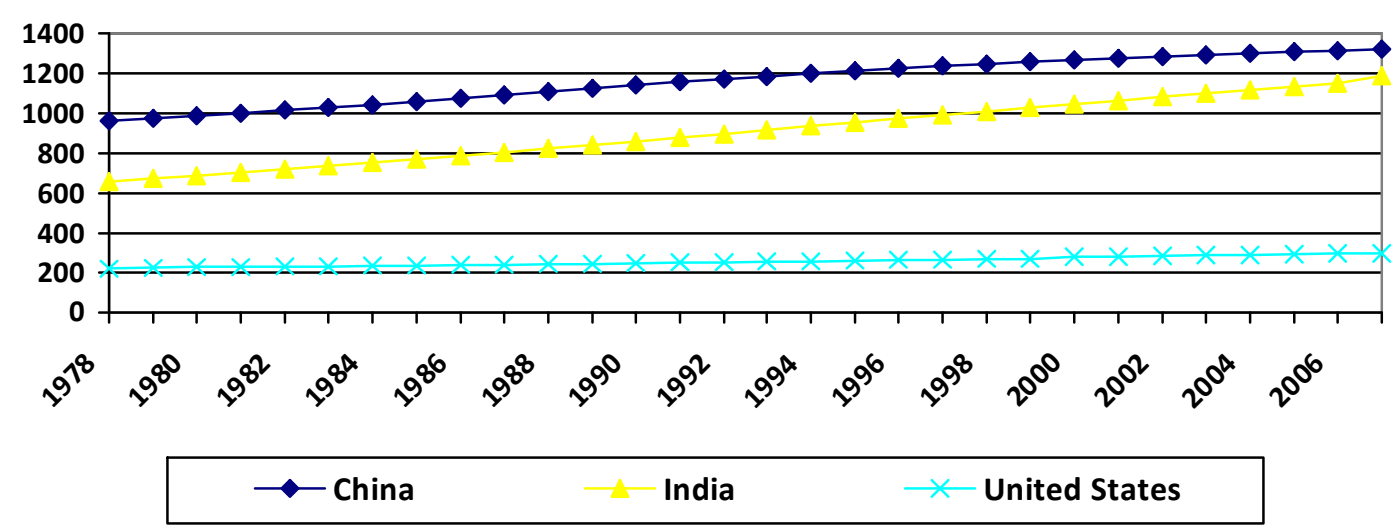

Source: 2008 China Statistical Yearbook; U.S. Census Bureau (2007); UN Data (2008) 
Figure 20: Population Density 1978-2007

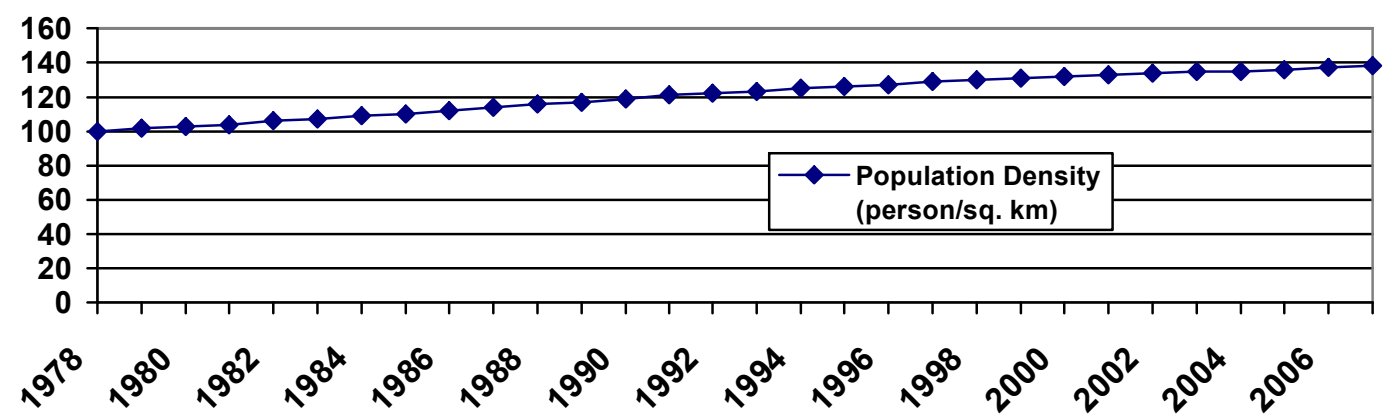

Source: China Population and Employment Statistics Yearbook, p.15

China's Family Planning policy and others have successfully lowered population growth in China but the existing size of the population has created many challenges. The divisions between rural and urban and east and west create ideal conditions for population mobility. A greater amount of areas in China are also now classified as urban. Annual income per capita for rural people has risen from 134 to 3,587 Yuan. For urban people it has risen from 343 to 11,760 Yuan. The average rural income was roughly $40 \%$ the value of the average urban income in 1978 . This grew to $54 \%$ in 1985 after rural reforms. Since the 1990s the average rural income has fallen to just over $30 \%$ of the average urban income in 2006 (see figures 21-23).

Figure 21: Per Capita Net Income of Rural and Urban Households 1978 - 2006

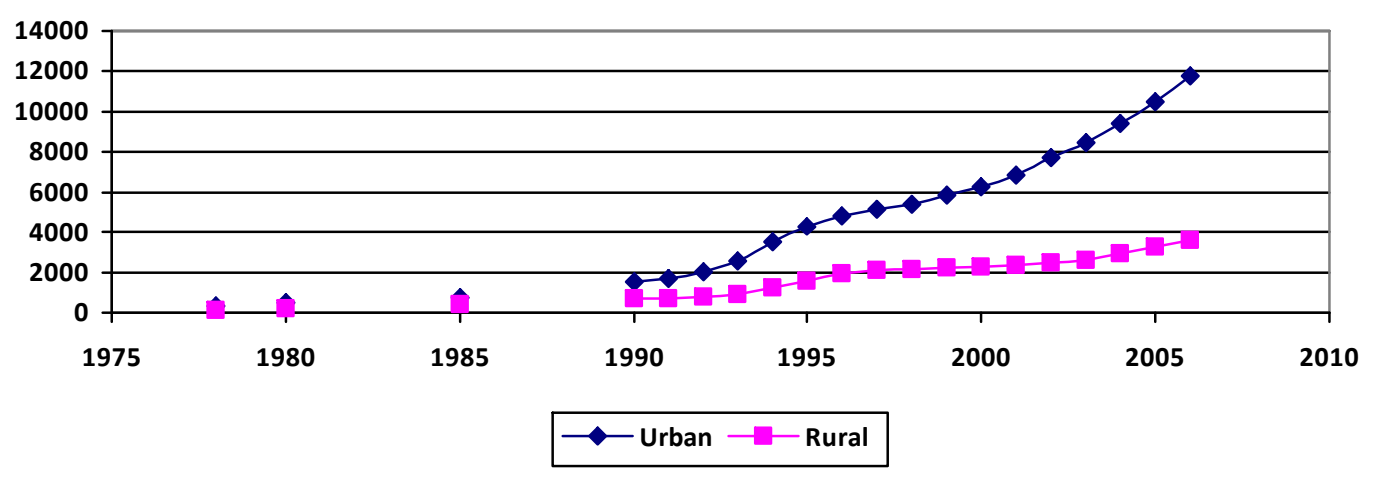

Source: 2007 China Statistical Yearbook (2007 values) www.stats.gov.cn/ 
Figure 22: Real Difference in Per Capita Net Income of Rural and Urban Households 1978 - 2006

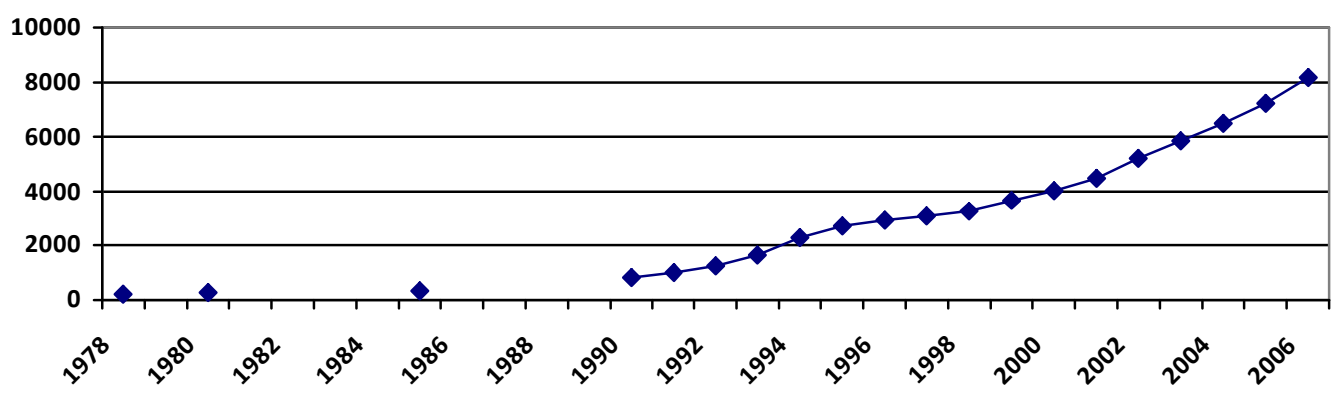

Source: Calculated from data from the 2007 China Yearbook

Figure 23: Per Capita Net Income of Rural Households as a Percentage of the Per Capita Net Income of Urban Households 1978 - 2006

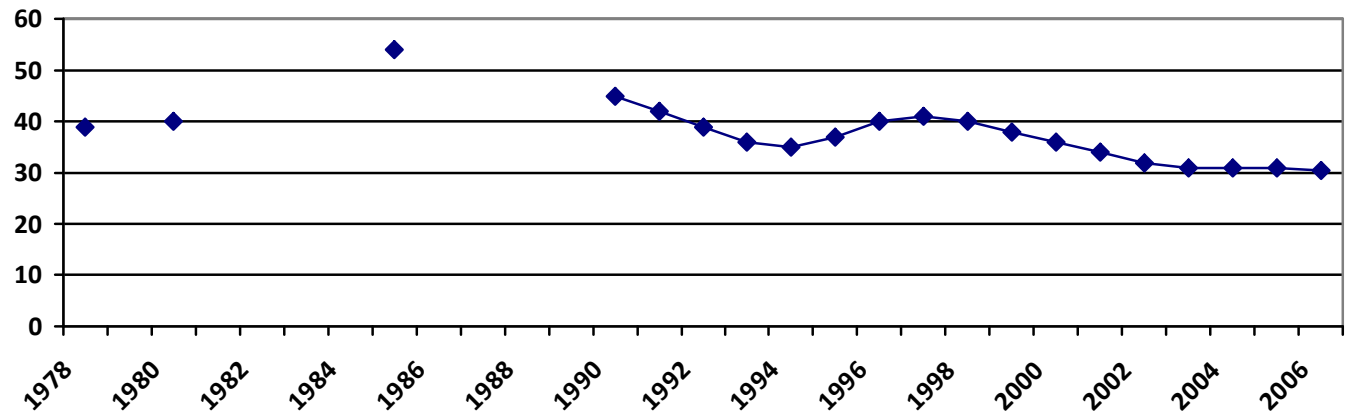

Source: Calculated from data from the 2007 China Yearbook

Recent government initiatives have sought to accelerate economic development in rural areas through agricultural tax system reform and agricultural subsidies as well as new rural medical healthcare systems, pension schemes and measures to improve social security. From 2000 to 2008, investment in central and western rural areas increased six fold. ${ }^{435}$ However, the proportion of completed investment in fixed assets actually significantly decreased (see figure 24). According to the NBS and China Labour Bulletin, living conditions between rural and urban have continued to remain disparate:

"The economic and social development of inland rural areas still lags far behind that of the coastal cities. By the end of 2006, only 48.6 percent of rural households had tap water, 60.2 percent were still using wood-burning stoves to cook and 87 percent did not have flush water. Only 9.6 percent of villages and towns could be reached by railways and 46 percent by grade two highways. "\$36

${ }^{435}$ China Labour Bulletin, "Rural and Urban Disparity in China," China Labour Bulletin http://www.china-labour.org.hk/en/node/100454\#10a.

${ }^{436}$ Ibid. 
Table 10: Rural Urban Living Conditions

\begin{tabular}{|l|c|c|c|c|c|c|c|c|}
\hline & \multicolumn{2}{|c|}{1990} & \multicolumn{2}{c|}{2000} & \multicolumn{2}{c|}{2006} & \multicolumn{2}{c|}{2007} \\
\hline $\begin{array}{l}\text { Number of TV Per } \\
100 \text { Households }\end{array}$ & 5 & 59 & 49 & 117 & 90 & 137 & 94 & 138 \\
\hline $\begin{array}{l}\text { Number of Computer } \\
\text { Per 100 Households }\end{array}$ & & & 1 & 10 & 3 & 47 & 4 & 54 \\
\hline
\end{tabular}

Source: 2008 China Statistical Yearbook www.stats.gov.cn/

Figure 24: Rural Urban Proportion of Investment in Fixed Assets

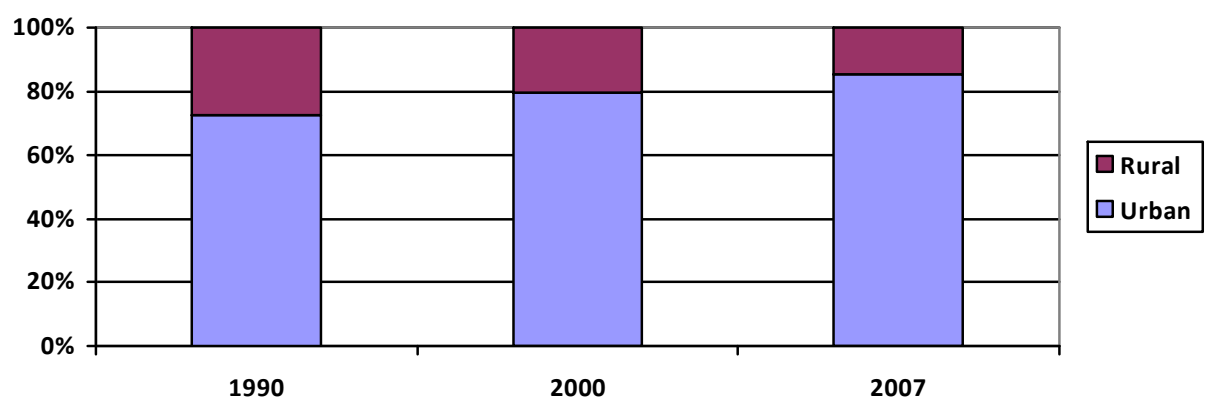

Source: China Labour Bulletin; China Statistical Yearbook 2008

Rural urban income disparity is more pronounced between remote central and western rural areas and urban areas in the east. This can be seen in life expectancy per region. Whilst life expectancy has improved overall it is still generally better in the east than in the central or western regions (see table 11).

Table 11: Life Expectancy by Region

\begin{tabular}{|l|c|c|l|c|c|l|c|c|}
\hline East & $\mathbf{1 9 9 0}$ & $\mathbf{2 0 0 0}$ & Central & $\mathbf{1 9 9 0}$ & $\mathbf{2 0 0 0}$ & West & $\mathbf{1 9 9 0}$ & $\mathbf{2 0 0 0}$ \\
\hline Beijing & 73 & 76 & Shanxi & 69 & 72 & Xinjiang & 63 & 67 \\
\hline Tianjin & 72 & 75 & Inner Mongolia & 66 & 70 & Tibet & 60 & 64 \\
\hline Hebei & 70 & 73 & Jilin & 68 & 73 & Gansu & 67 & 67 \\
\hline Liaoning & 70 & 73 & Heilongjiang & 67 & 72 & Qinghai & 61 & 66 \\
\hline Shanghai & 75 & 78 & Anhui & 69 & 72 & Sichuan & 66 & 71 \\
\hline Jiangsu & 71 & 74 & Jiangxi & 66 & 69 & Yunnan & 63 & 65 \\
\hline Zhejiang & 72 & 75 & Henan & 70 & 72 & Guizhou & 64 & 66 \\
\hline Fujian & 69 & 73 & Hubei & 67 & 71 & Shaanxi & 67 & 70 \\
\hline Shandong & 71 & 74 & Hunan & 67 & 71 & Ningxia & 67 & 70 \\
\hline Guangdong & 73 & 73 & & & & Chongqing & & 72 \\
\hline Guangxi & 69 & 71 & & & & & & \\
\hline Hainan & 70 & 73 & & & & & & \\
\hline
\end{tabular}

Source: 1991 and 2001 China Statistical Yearbook www.stats.gov.cn/

The proportion of gross regional product (GRP) has remained steady since 1992 . The east has consistently accounted for around $60 \%$ of GRP (see figure 25 ). The population of the east has also consistently been larger than the central or western regions (see 
figure 26). Whilst a larger population provides the east with more opportunity to create GRP, after accounting for population differences, the east has still accounted for over $50 \%$ of GRP over the last ten years of the period of study (see figure 27 ).

Figure 25: Proportion of Gross Regional Product 1992-2007

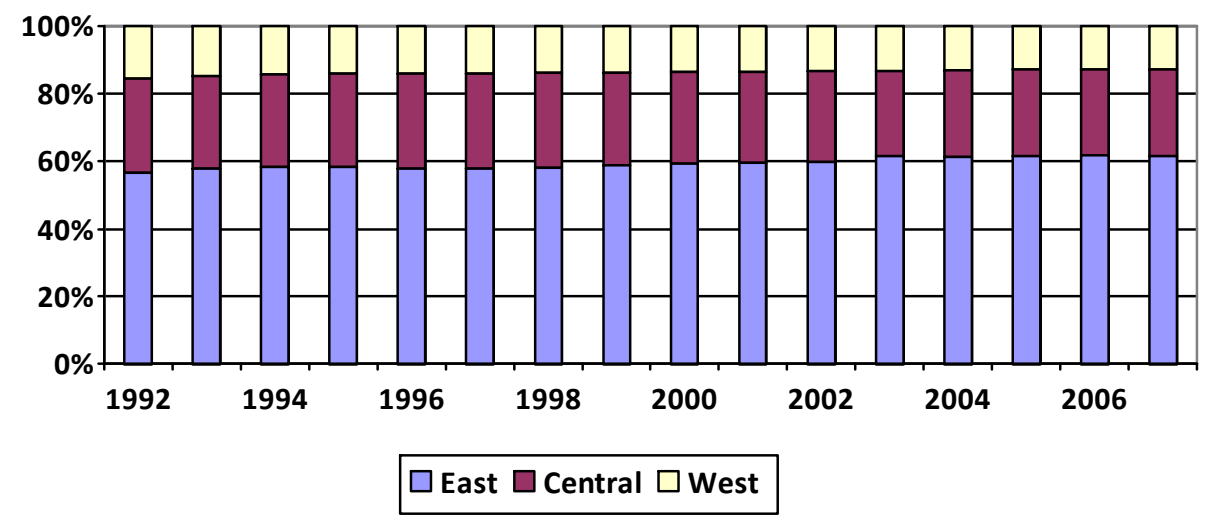

Source: 1993-2008 China Statistical Yearbooks www.stats.gov.cn/

Figure 26: Population by Region 1997-2007

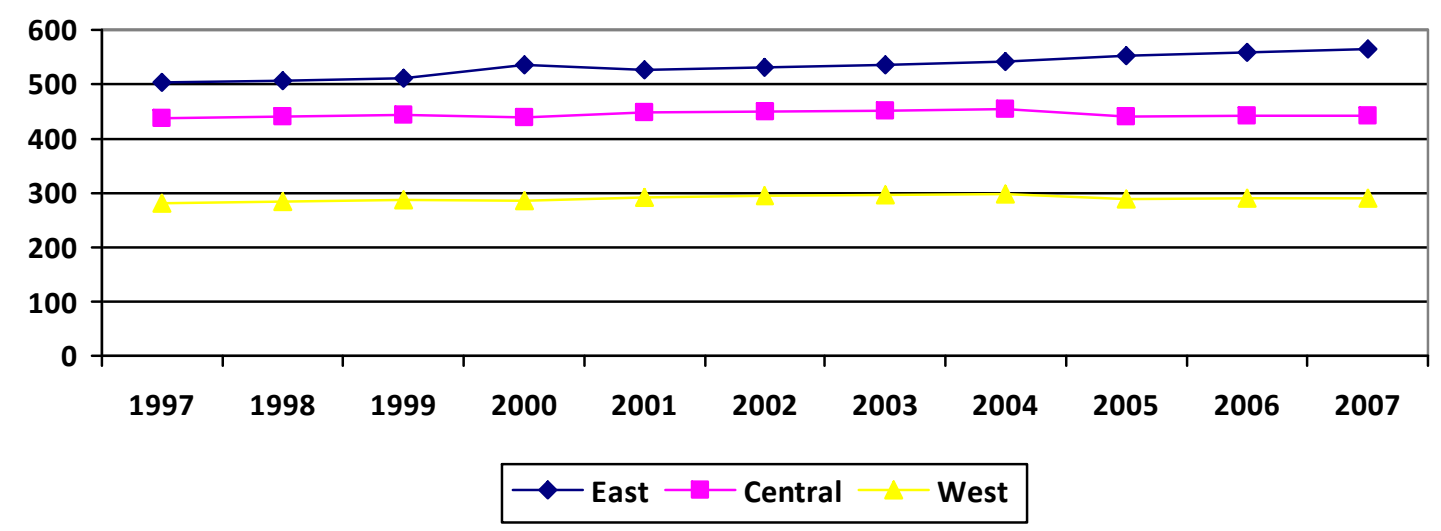

Source: 1993-2008 China Statistical Yearbooks www.stats.gov.cn/

Figure 27: Proportion of Gross Regional Product Per Capita 1992-2007

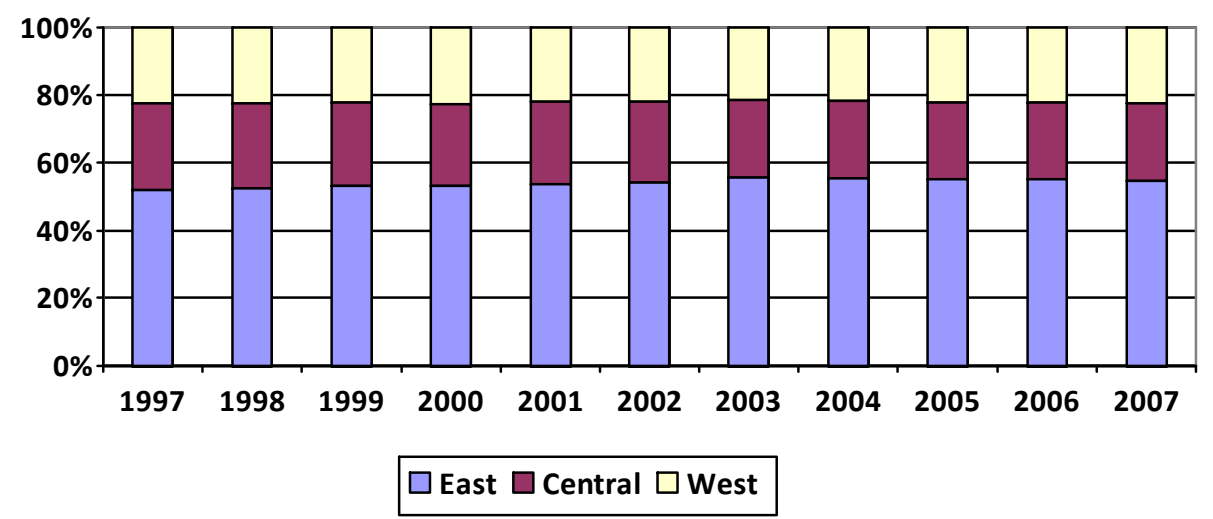

Source: 1993-2008 China Statistical Yearbooks www.stats.gov.cn/ 
The growing population, increasing population density, disproportionate asset investment in rural and urban areas and relative decreases in agricultural and rural incomes creates ideal rural to urban labour migration conditions. Compounding this is the stark differences in standard of living and GRP proportion over eastern, central and western regions. This disparity also increases push and pull forces that have motivated western and central people to cross provincial boundaries in search of a better wage. Whilst urbanisation pressures are similar to those experienced by other developing nations the actual urbanisation process has been unique due to the continued role of the huji institution.

\subsubsection{The Role of the State}

Strict control of permanent hukou transfer has remained throughout the reform era. Experiments in the reform of nongzhuanfei and increased hukou transfer have had limited success in small cities and towns and even less in medium and large municipalities. The objective to control urbanisation through controlled transfer of permanent hukou status and associated rights to the urban rationing regime has moved to efforts to manage and restrict urbanisation through limited and targeted hukou transfer and the limited desirability of temporary status. Nongmingong remain treated as temporary in the areas they work and reside. They are a new social class neither rural nor institutionally granted urban status. This new institutional category has allowed local urban governments to maintain their strict hukou transfer quotas whilst "non-hukou urbanisation' increases significantly. ${ }^{437}$ These strict quotas decrease the desirability of settlement in urban areas by excluding non-hukou migrants from local services and benefits. This arguably decreases the size of the new-migrant population in urban areas

\footnotetext{
437 Chan and Buckingham found that for each locale, the annual quota of nongzhuanfei remained controlled by the central government at 0.15 to 0.2 per cent of the non-agricultural population. Kam Wing Chan and Will Buckingham, "Is China Abolishing the Hukou System?," The China Quarterly 195, no. September (2008), p.591.
} 
comparable to an open hukou transfer policy. ${ }^{438}$ Increasing localisation of decisionmaking has also led to hukou transfer being used as a means to attract the best and the brightest through residency schemes. Wealth, talent or assets have become the means to gain hukou transfer into urban and economically more affluent hukou zones. Residency schemes are also being used by local governments to encourage urbanisation to certain areas of China away from larger municipalities and to incrementally address the gap between the rate of urbanisation and the rate of urban hukou transfer.

The State Council Notification Regarding the Problem of Nongmin Settling in Market Towns was enacted in $1984 .{ }^{439}$ Existing non-agricultural hukou holders with work and stable residence and a means of self-provision in market towns could apply to the local government to transfer to a non-agricultural self-supporting hukou. This provided nongmin with a form of 'permanent residence' and effectively increased China's nonagricultural hukou population in less densely populated urban areas. This was intended to divert migrations from larger urban areas by increasing the attractiveness of migration to market towns as part of the goal to urbanise from below. Temporary permits were introduced in 1985 in the face of increasing 'outside the plan migration'. The floating population increased significantly from this time on (see figure 28).

\footnotetext{
${ }^{438}$ The assumption here is that an open hukou transfer policy would lead to greater levels of urbanisation, especially in comparatively developed regions such as Beijing, Shanghai and Guangdong. This suggests authorities in these urban areas as well as central government continue strict hukou transfer policies to avoid the possibility of increased urbanisation; that they want to slow urbanisation.

439 《国务院关于农民进入集镇落户问题的通知》; An earlier directive in 1980 had also liberalised nongzhuanfei for workers and cadre with special skills 《关于解决部分农业技术干部的农村家属迁往 城镇由国家供应粮食问题的规定》.
} 
Figure 28: National Floating Population 1980-2005 (millions)

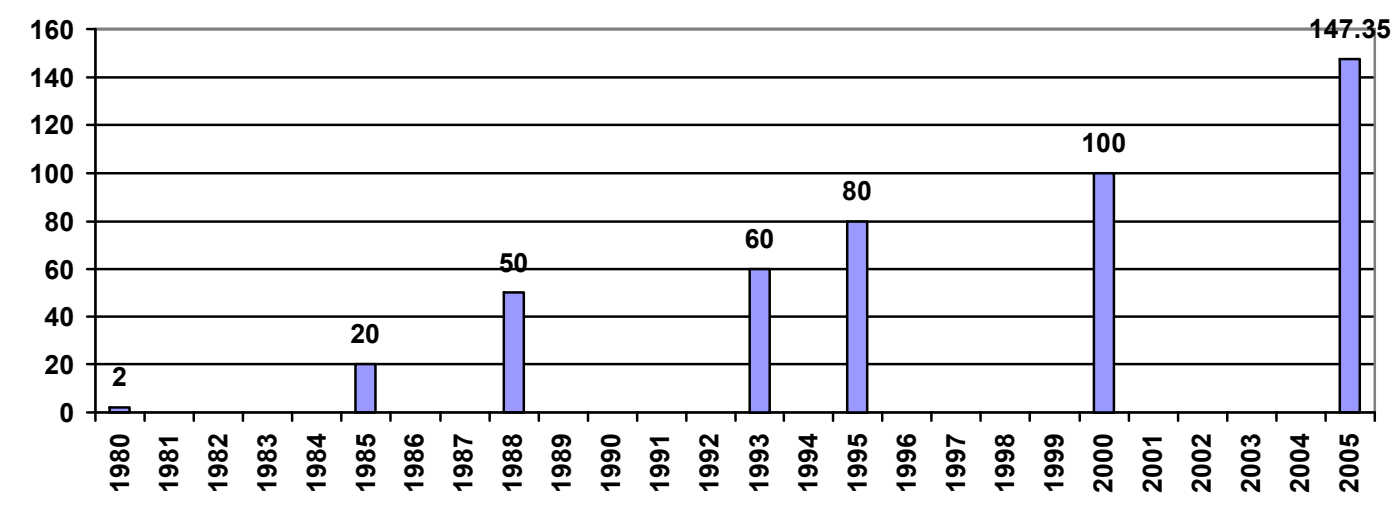

Source: 2005 China Population, p.114

Temporary permits allowed local governments to continue their strict hukou transfer policies. The State Council issued directives to decrease nongzhuanfei quotas in $1991,{ }^{440}$ and the MPS addressed some of the new problematic trends in the management of hukou transfer in urban areas. This was followed by the Ministry of Commerce and MPS directive in 1991 that strengthened governance of the 1984 regulations introducing the 'self-supporting grain hukou'. ${ }^{441}$ This new non-agricultural hukou qualified for nongzhuanfei but with 'self-supporting grain' and so did not qualify for provisions such as grain under the 'urban rationing regime'. Overall, nongzhuanfei quotas remained and the expected reasons for hukou transfer to a densely populated urban area were still limited to the standard three (transfer to XX work unit; studying at XX school; joining family). ${ }^{442}$ Such categories were of little use to nongmingong labouring in urban areas or swallowed up by the spread of urbanisation and industrialisation. As China's urbanisation figures swelled in the 1990s so too did the size of the temporary population.

\footnotetext{
${ }^{440}$ Notification of Recommendations Regarding the Distribution of 'Nongzhuanfei' Policy Management Work 《关于 “农转非” 政策管理工作分工意见报告的通知》; Notification Regarding Practically Resolving Difficulties the Masses have Processing Hukou 《公安部关于切实解决群众办户口难问题的 通知》.

${ }^{441}$ Notification Regarding Issues Relating to Handling 'nongzhuanfei' Housing and Provisions for Personnel with 'Self-supporting Grain Hukou’ 《商业部公安部关于自理口粮户口人员 “农转非” 办 理户粮关系有关问题的通知》.

${ }^{442}$ Notification Regarding Using New Hukou Relocation Certificate, [and] Hukou Permits (1994); Notification Regarding Issues Relating to Hukou Transfer for Redeployed Cadres, [and] Labourers (1994).
} 
Hukou transfers involving nongzhuanfei fell well below the rate of urbanisation as hukou transfer regulations were strengthened and better enforced.

A small minority of these temporary migrants did however become permanent residents through a variety of local residency schemes. These included the 'Green Card Huji System' trialled in an urban area in Anhui Province in 1986; the 'Green Card System' introduced in 1992 in a county in Zhejiang Province; the 'Blue Chop Hukou System' introduced in Shanghai in 1993; and the 'Blue Chop Hukou System' introduced in Shenzhen in 1995. During Deng Xiaoping's Southern Tour in 1992 the MPS issued an early directive outlining the 'Blue Chop Hukou' system signalling their willingness to incorporate residency schemes into huji management. ${ }^{443}$ These residency schemes generally prioritised investment, skilled employment or business ownership. This became the basis for reform experiments from the mid 1990s on.

In 1993 a State Council draft proposal was issued. ${ }^{444}$ This recommended the abolishment of hukou dualism (agricultural and non-agricultural hukou division) to be replaced with three types of hukou: permanent hukou; temporary hukou; and visitor hukou. ${ }^{445}$ It also recommended localisation of huji management. Various experiments throughout the 1990s and 2000s have attempted to do these things. In 1995 the MPS approved a new plan for experimentation in huji reform in 8 provinces and cities, ${ }^{446}$ with support from the State Council. ${ }^{447}$ The reforms proposed public security organs in these 8 experimental areas introduce residency schemes to allow nongmin residing in

\footnotetext{
443 《关于实行当地有效城镇居民户口制度的通知》.

444 《国务院关于户籍制度改革的决定》。

445 常住户口、暂住户口、寄住户口.

446 《建设部关于认真配合做好小城镇户籍改革工作的通知》; 《关于建议将八县（市）列为 “小城 镇户籍制度改革”试点的报告》.

447 State Council Decision Regarding Issues with Reform and Improvement of Rural Urban Huji Management 《国务院关于改革和完善城乡户籍管理制度若干问题的决定》.
} 
these small cities and towns with fixed accommodation and steady work or business to apply for non-agricultural hukou and a variety of urban benefits.

In 1997 the Ministry of Public Security issued the Blueprint for Experiments in Small City and Town Huji Management Reform, ${ }^{448}$ and Recommendations Regarding Perfecting the Rural Huji Management System. ${ }^{449}$ The State Council also issued notification of this reform experiment and the MPS sent out further clarification of the process. ${ }^{450}$ Rural Huji Management System was designed to strengthen the huji institution in rural areas in the face of increasing non-compliance, poor implementation and weak unification with the national system. The previously lax enforcement of huji regulations in rural areas was to be replaced with strict enforcement as seen in urban areas.

The Blueprint for experimentation in huji reform in small cities and towns was designed to experiment with increased nongzhuanfei in low density urban areas. Hukou transfer (to an urban, permanent, non-agricultural hukou) into these experimental zones was limited to nongmin who had been engaged in non-agricultural employment (or had a steady source of income) and a fixed domicile (bought, allocated by a work unit or rented; not including temporary rentals) for over two years in the area (proven by temporary permit records). Medium and large cities were explicitly excluded from the reforms and public security officials were required to 'continue to strictly control the mechanical rise in population of large and medium sized cities, especially Beijing,

\footnotetext{
448 《小城镇户籍管理制度改革试点方案》.

449 《关于完善农村户籍管理制度的意见》.

${ }^{450}$ State Council Notification and Endorsement of Ministry of Public Security Recommendations for the Programme of Experiments in Reform of the Small City and Town Huji Management System and Regarding Perfecting the Rural Huji Management System 《国务院批转公安部小城镇户籍管理制度改 革试点方案和关于完善农村户籍管理制度意见的通知》; 'Reply to Issues Related to Experiments in Reform of the Small City and Town Huji Management System and Perfecting the Rural Huji Management System' (Ministry of Public Security) 《关于小城镇户籍管理制度改革试点和完善农村户籍管理制度 有关问题的解答》.
} 
Tianjin and Shanghai etc.' This signalled the use of the huji institution to direct rural to urban migration to increase urbanisation from below. But it was also tacit recognition of the inability of the huji institution to prevent massive non-hukou migration to urban areas including Beijing, Tianjin, Shanghai and Guangdong.

“...since reform and opening and especially in areas where the socialist market economy has developed, the huji management system can no longer completely adapt to the requirements of development. ${ }^{, 451}$

The reform measures aimed to 'macro control' the gross size of the small city and town population as a way to improve their economic development. Local governments were urged to avoid 'rushing into mass action' by blindly enlarging the population scale of the experimental zone and weakening the agricultural base of the economy. Careful auditing of increases in population was to be conducted by the authorities in conjunction with higher levels of local government who would also control the budget for the proposed reforms. The reform experiments were designed to 'solve' the hukou problem of the following groups of people.

Table 12: Small City and Town Hukou Transfer Eligibility

\begin{tabular}{|c|l|}
\hline 1. & $\begin{array}{l}\text { Those personnel from rural areas who labour or set up secondary [or] tertiary industries in a } \\
\text { small city or town }\end{array}$ \\
\hline 2. & $\begin{array}{l}\text { Managers and personnel in specific technical fields that are employed in a work unit of a } \\
\text { government department, group, corporation or enterprise in a small city or town }\end{array}$ \\
\hline 3. & Residents who purchased commercial housing or legally built a house in a small city or town \\
\hline 4. & $\begin{array}{l}\text { Foreign business people, overseas Chinese and Hong Kong, Macao and Taiwan compatriots } \\
\text { who invest to start a business or own property in a small city or town }\end{array}$ \\
\hline 5. & Nongmin residing in a small city or town who had their land confiscated in that area \\
\hline
\end{tabular}
Source: Small City and Town Huji Management, $1997^{452}$

In 1998 the State Council and the MPS issued further directives clarifying eligibility for nongzhuanfei and transfer to permanent residence in urban areas. ${ }^{453}$ They strove to

\footnotetext{
${ }^{451}$ Blueprint for Experiments in Small City and Town Huji Management Reform.

452 'Reply to Issues Related to Experiments in Reform of the Small City and Town Huji Management System and Perfecting the Rural Huji Management System' (Ministry of Public Security) 《关于小城镇户 籍管理制度改革试点和完善农村户籍管理制度有关问题的解答》。

${ }^{453}$ Recommendations Regarding Resolving Several Issues with Current Hukou Management Work 《关 于解决当前户口管理工作中几个突出问题的意见》; Notification Regarding Issues Relating to Carrying Out Putting into Effect 'State Council Notification and Endorsement of the Ministry of Public Security Recommendations Regarding Resolving Several Issues with Current Hukou Management Work'
} 
'accelerate rational, orderly population flows, economic development and social advancement, ${ }^{454}$ at the same time as "continuing to adhere to strictly controlling the size of large cities and rationally developing medium and small cities. ${ }^{455}$ Huji reforms in small cities and towns are described as a 'critical step' in the integration and reform of the national huji institution. Incremental reform beginning in small cities and towns is promoted.

'...the state of affairs is comparatively complex ... it is impossible to resolve all issues within a
short time frame. ${ }^{456}$ Especially large cities, such as Beijing and Shanghai, were signalled out for continued strident population control and all cities maintained control of hukou transfer and the ability to determine the annual growth of the local permanent population. Small cities and towns were directed to allow relatives, investors, business people and property owners and their families with employment or a source of income and legal domicile for over one year to apply for residency. This signalled an increasing use of the huji institution to attract skilled and investor migrants in localised efforts to increase the 'quality' of their populations. ${ }^{457}$ But as two further MPS directives in 1998 on huji management reform show, even in experimental zones at the small city and town level, strict quotas for nongzhuanfei and hukou transfer remained. ${ }^{458}$ The 1998 transfer quotas remained significantly lower than the quota for population growth. Settlement quotas were highest in the east (see figure 29).

\footnotetext{
关于贯彻落实《国务院批转公安部关于解决当前户口管理工作中几个突出问题意见的通知》有关 问题的通知.

454 促进人口合理、有序流动, 促进经济发展、社会进步.

455 继续坚持严格控制大城市规模、合理发展中等城市和小城市.

456 情况比较复杂, 不可能在短时间内全部解决.

457 素质.

4581998 Experiments in Small City and Town 'Nongzhuanfei' Population Planning 《1998 年试点小城

镇 “农转非” 人口计划》; Notification Regarding Making Known to Lower Levels the 1998 Experiments in Small City and Town Rural Population Controlled Planning of Processing Urban Permanent Hukou 《关于下达 1998 年试点小城镇农村人口办理城镇常住户口控制计划的通知》.
} 
Figure 29: Nongzhuanfei Settlement Quotas and Population Plans for Small Cities and Towns (1998)

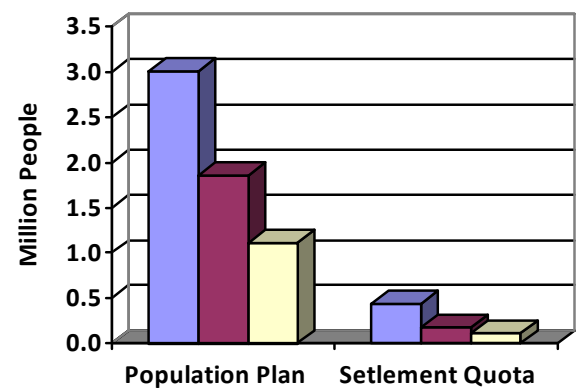

(a)

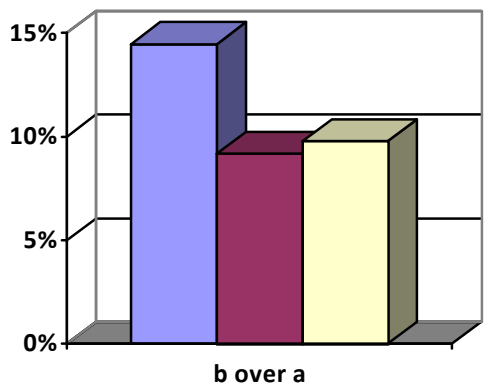

b over a $\square$ East

$\square$ Central

$\square$ West

\section{Source: MPS $1998^{459}$}

Local authorities are under strict guidelines to limit the growth of the urban population.

This is done by placing quotas on natural population growth and through quotas on hukou transfer. The 1998 regulations show this occurs even in experimental small cities and towns. The national population growth quota of 7 million people is 10 times larger than the quota for settlement involving hukou transfer $(700,000)$. In 1998 the population of China was 1.25 billion making the number of nongzhuanfei transfers in small cities and towns a mere $0.056 \%$ of the population, below the actual rate of urbanisation in these areas. The natural growth of the urban population in small cities and towns was to be limited to just below $0.5 \%$ of the national population. As of 2007 , small cities and towns as well as larger cities and municipalities were still subject to these strict quotas for natural population growth, the growth of the temporary population and nongzhuanfei. $^{460}$

\footnotetext{
${ }^{459}$ Note: the nongzhuanfei total and settlement quotas do not add up to these totals. The totals are, 5,985,000 for the population plan and 715,000 for the settlement quota.

${ }^{460}$ Harbin Rural and Urban Planning Bureau 哈尔滨市城市规划局. 《镇规划标准: 中华人民共和国 国家标准 gb 50188 - 2007》 [Town Planning Standards: People's Republic of China National Standards Gb 50188 - 2007]. 哈尔滨市城市规划局[Harbin Rural and Urban Planning Bureau], 2007 http://www.hrbghj.gov.cn/view/caghxgfg/article/013238.html.
} 
In 2001 huji management reform in small cities and towns was 'accelerated' by the State Council and MPS. ${ }^{461}$ This directive referred to the previous reform experiments in small cities and towns and rural areas begun in 1997 as having a 'marked effect' and reiterated the need to reform the huji institution to contemporary conditions and requirements of the socialist market economy. Article 1 states:

"Reform of the small city and town huji management system [will] guide the orderly transfer of the rural population to small cities and towns, accelerate the healthy development of small cities and towns and quicken China's process of urbanisation from below. At the same time [it will] establish a base for general reform of the huji management system. ${ }^{462}$

The economic development of low density population urban areas as well as rural areas is put forward as the primary goal of the reforms. Local officials are cautioned to keep in mind the 'bearing capacity' of these areas, ${ }^{463}$ to not rush in and blindly expand the scale of transfers which could adversely affect agricultural production (and social stability) and to uphold a legal, scientific, standardised and modern process whilst concurrently adapting measures to local conditions. The reforms applied to 'city zones in urban areas at the county level', in particular, 'towns and organic towns under the county people's government, ${ }^{464}$ where nongmin can apply for a 'small city and town permanent hukou'. ${ }^{465}$ The public security bureaus at the county level became responsible for the development of the small cities and towns and no longer needed to adhere to the central government quotas. ${ }^{466}$ This was a significant move towards greater local autonomy. However, as the recommendations also required local governments to ensure the 'healthy development' of their urban areas and urged them not to go too far, this did not necessarily mean a more relaxed and liberalised residency scheme in small

\footnotetext{
${ }^{461}$ Recommendations Regarding Accelerating Reform of the Small City and Town Huji Management System 《国务院批转公安部关于推进小城镇户籍管理制度改革意见的通知》.

462 'Urbanisation from below': 城镇化.

463 承受能力.

464 县级市市区、县人民政府驻地镇及其他建制镇.

465 城镇常住户口.

${ }^{466}$ Article 3, point 2: “对办理小城镇常住户口的人员, 不再实行计划指标管理。”
} 
cities and towns. In fact, this gave local governments the green light to continue to implement strict protectionist policies and to use hukou transfer as a developmental tool.

The MPS put out further clarification of issues relating to these reforms in huji management in small cities and towns late in $2001 .^{467}$ This reiterated the importance of the reforms for overall huji management reform and requested local governments 'carry out the spirit of the 15th Session of the Third and Fifth National Committee of CPPCC, and the Central Committee of the Communist Party of China, State Council Recommendations Regarding Accelerating the Healthy Development of Small Cities and Towns. ${ }^{468}$ Local public security organs were to ensure the reform experiments were carried out with the twin goal of development and stability in mind and in a unified manner. The outcome of the small city and town huji management reforms and reforms in larger municipalities has led to a conservative approach to further reform developing.

\subsubsection{A New Status Quo}

Over the reform era there has been a growing discrepancy between the level of urbanisation and the number of people with urban or non-agricultural hukou. This problem has resulted from the growth in urbanisation not being met by the number of hukou transfers to urban areas. Physical growth of cities has appropriated outlying rural areas. Agricultural hukou holders in these areas have often had their land expropriated by local government and are now engaged in non-agricultural work. This population is permanent and local but remains agricultural. China's nongmingong on the other hand, are both non-agricultural and non-local. They migrate into urban areas and perform urban work on temporary permits. In 2007 the NBS classified 594 million people as

\footnotetext{
467 公安部关于贯彻落实《国务院批转公安部关于推进小城镇户籍管理制度改革意见的通知》有关 问题的通知.

468 党的十五届三中、五中全会和《中共中央、国务院关于促进小城镇健康发展的若干意见》.
} 
urban but the MPS only recorded 431 million non-agricultural or urban hukou (see table $13)$.

Table 13: Urbanisation and MPS Hukou Type in 2007

\begin{tabular}{|c|c|c|c|c|c|}
\hline & $\begin{array}{c}\text { Total } \\
\text { Population }\end{array}$ & Urban & Proportion & Rural & Proportion \\
\hline $\begin{array}{c}\text { Level of } \\
\text { Urbanisation }\end{array}$ & 1321 & 594 & $45 \%$ & 727 & $55 \%$ \\
\hline & Total Population & $\begin{array}{c}\text { Non- } \\
\text { Agricultural }\end{array}$ & Proportion & Agricultural & Proportion \\
\hline $\begin{array}{c}\text { MPS Hukou } \\
\text { Type }\end{array}$ & 1309 & 431 & $33 \%$ & 878 & $67 \%$ \\
\hline
\end{tabular}

Source: China Population and Employment Statistics Yearbook 2008, p.5 \& p.293

This discrepancy has been the focus of the reform experiments that started in small cities and towns in the mid-1990s. These and other experiments in huji reform in larger municipalities have largely failed to address this disjoint between the level of urbanisation and urban hukou status. A report by the State Council Research Team in 2006 reviewed huji management reform in Chongqing City, Ningbo City, Shijiazhuang City, Zhengzhou City and Jiangsu Province. ${ }^{469}$ Chongqing City began reform in 1994 during the Small City and Town Huji Management Reform Experiments. By 1997 they had expanded this to include hukou transfer for all non-agricultural workers with steady employment and fixed domicile in organic towns and villages. The small cities and towns in Chongqing City increased their hukou transfer by on average 80,000 per year. In 2000 they relaxed regulations on hukou transfer for relatives and skilled labour, investment and industry categories (above certain tax payment levels) and students. Then from September 2003 they cancelled agricultural and non-agricultural hukou and replaced it with a unified Chongqing City Resident Hukou. However, the reforms did not address the needs of the temporary population because of the requirement for

\footnotetext{
${ }^{469}$ Wang Fei 王飞, and Liu Wenhai 刘文海. "部分地方户籍制度改革情况调查报告" [Research Report on the Conditions of Reform of the Huji Institution in Selected Areas]. In 《中国农民工调研报告/国务 院研究室课题组》[China's Nongmingong Research Report/Discussion Group of the Research Department of the State Council], edited by Wei Liqun 魏礼群 and Han Changfu 韩长赋.北京 [Beijing]: 中国言实出版社 [China Yanshi Press], 2006.
} 
'steady employment and stable residence'. Purchasing an apartment was a high bar so few of the hukou transfers in this period involved nongmingong.

"...even though Chongqing City appeared to have removed hukou dualism, the treatment of city residents in areas such as land compensation, veteran care, traffic accident compensation, social security and others remained different. ${ }^{, 470}$

In 1998 Ningbo City removed the central government nongzhuanfei quota and processed a backlog of applications for hukou transfer. It increased transfer of non-local workers with stable residency and employment and attracted skilled labour and investment transfers through special residency categories. Hukou transfer and settlement was conditional on applicants owning or buying an apartment of a certain size. Ningbo City also established 'urban administration' for 'villages in the cities' and satellite towns. By 2005 there had been 200,000 nongzhuanfei transfers and the city resident population increased yearly by roughly 40,000 people or $1 \%$ of the urban city population. Even so, of the total population of 5.52 million in 2004, only 1.76 million held non-agricultural hukou (32\%). Whilst Ningbo City had liberalised some hukou transfer conditions the requirement for home ownership placed it out of reach of most migrant workers. The city government also found that in quickly developing suburbs many nongmin did not want to transfer their hukou through nongzhuanfei. This is because their land would be expropriated by the local government and they would lose their home, their land contract and their right to the yearly cut from the town and village collective.

Shijiazhuang City went through three main periods of huji reform. Incremental reform was replaced by complete relaxation of transfer conditions followed by retrenchment and a new status quo. In 1999 they allowed relatives and investors to transfer hukou into the city. This was a minor reform that only increased transfers by 20,000 by 2001 . Then,

${ }^{470}$ Ibid. 
in August 2001 the city government lowered almost all hukou limits. From then until September 2003 there were 142,000 hukou transfers into the city and 306,000 transfers for 'villages in the city'. Finally, in September 2003 Shijiazhuang City effectively scaled back the reform by introducing the requirement for 'legal fixed residence and stable employment or source of income'. Over the next two years there were only 45,000 transfers, mostly for relatives, investors and skilled labour/graduates. These reforms mostly targeted 'villages in the cities' and were scaled back considerably after the two year 'open' experiment. At present, the yearly increase in the urban population is $1 \%$, about the national average.

Zhengzhou City also liberalised and then strengthened hukou transfer conditions. In 2001 the city government lowered the conditions for hukou transfer. From 2003, they cancelled 'agricultural hukou', 'temporary hukou', 'small city and town hukou', 'nonagricultural hukou' and other categories of hukou and established a unified 'Zhengzhou Resident Hukou' system. Workers from other areas had access to two residency categories: firstly, those signing a labour contract and entering social security schemes; secondly, through a hukou transfer award set up for '110 outstanding nongmingong'. From August 2003 until April 2005, 276,000 people moved into and settled in Zhengzhou, $57 \%$ of which used the relatives' category. The city government reported the population growth created social problems such as in education where there were 70-100 students per class. By August 2004 they had returned to pre-reform huji management much as Shijiazhuang City had done.

In Jiangsu Province selected cities trialled relaxing hukou transfers with similar regulations as the other experiments. Jiangsu Province however added the requirement that transfer must meet the requirements of the city economy. Local authorities reported 
that this avoided a flood of migrants and was more stable. Jiangsu Province increased its level of urbanization from $31.5 \%$ in 1998 to $48.2 \%$ in 2004 through residency schemes designed to attract investment and skilled labour/graduates and to try to address the problem of 'villages in the city'. These schemes were not generally applicable to nongmingong because the conditions were too high.

The results of the reform experiments hailed as the first step in overall huji system reform have led to a conservative approach by local authorities who now control the level of hukou transfer where previously they were instructed to follow central government quotas. The cases of Shijiazhuang City and Zhengzhou City showed local governments that liberalising hukou transfer, at least in the short term, increases the size of the permanent urban population significantly. From these examples it is clear that local governments in China have enormous powers to manage and restrict urbanisation which they continue to use. They do this by attracting rich, educated and skilled migrants and by controlling the growth of the permanent urban population by raising and lowering entry level criteria. Local authorities control the growth of the permanent urban population and try to ensure the best and the brightest transfers. Nongmingong are for most still relegated to a second-tier temporary urban status with little hope of obtaining hukou transfer. This increases the likelihood of return migration, creates a sub-class within the city that provides low-priced labour for urban industries and slows the rate of urbanisation and inward migration. This is the new status quo that has emerged though it is often hidden by standard urbanisation figures.

Over the reform era the size of the urban population has more than tripled growing from 172 million in 1978 to 594 million in 2007 . China's rural population of 790 million in 1978 incrementally climbed to an all time high of 859 million in 1995 after which time 
it slowly dropped to 728 million by 2007 (see figure 30). In 1978 the rural population accounted for $82 \%$ of the national population. By 2007 this had dropped to $55 \%$. The level of urbanisation has grown from $18 \%$ to $45 \%$ (see figure 31 ).

Figure 30: Rural Urban Population 1978 -2007 (millions)

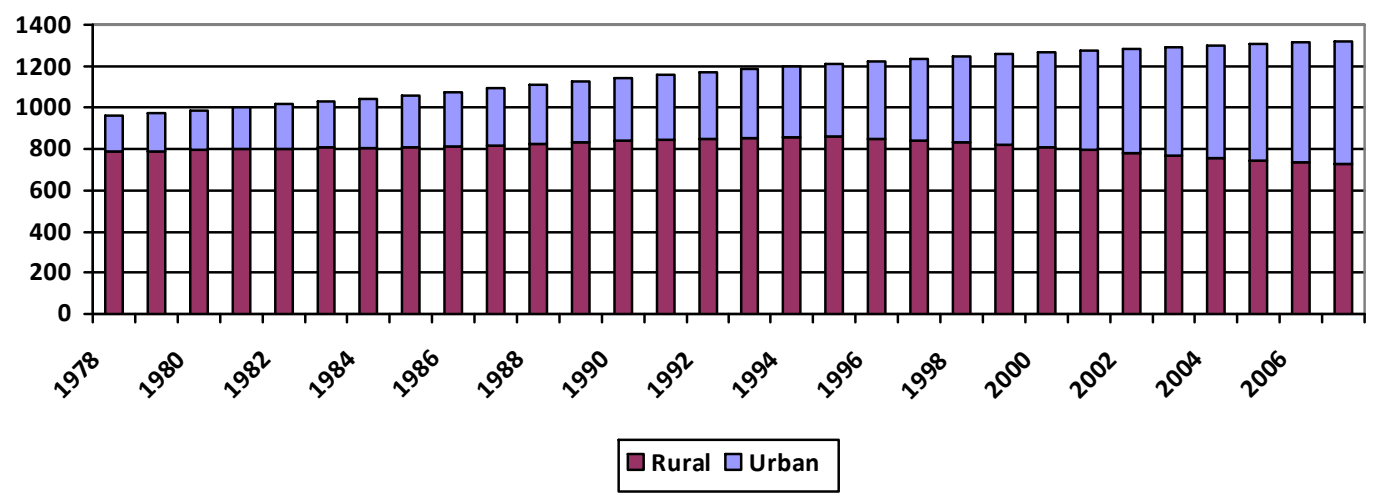

Source: China Population and Employment Statistics Yearbook 2008, p.5

Figure 31: Rural Urban Population 1978-2007 (\%)

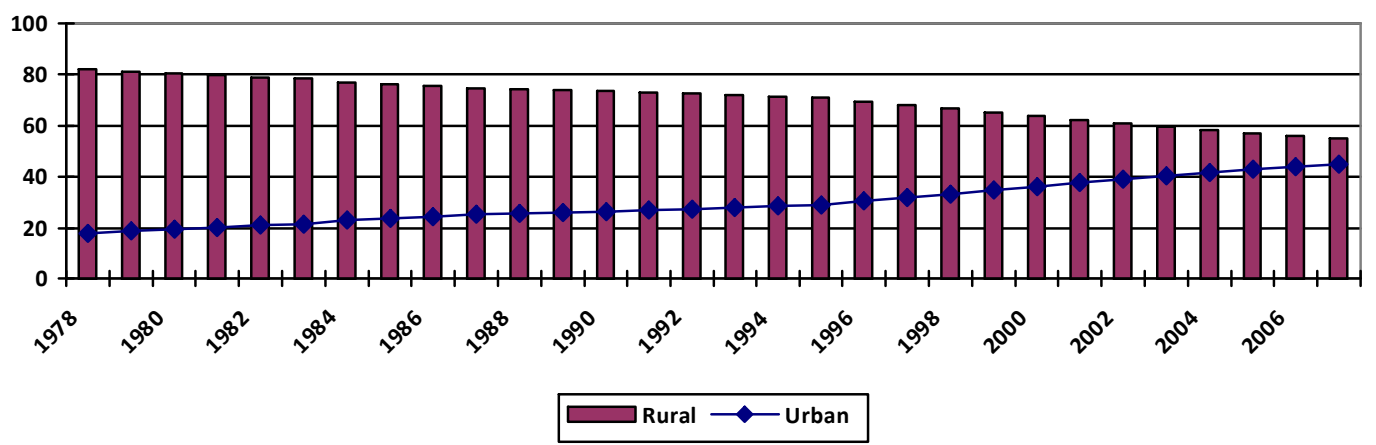

Source: China Population and Employment Statistics Yearbook 2008, p.5

The growth of the urban population and decline of the rural population has been due to the spread of urbanisation and movement of rural people into urban areas. The rate of growth from 1978 to 2007 was $244 \%$ for the urban population and $-8 \%$ for the rural population. The urban population grew by 421 million people and the rural population declined by 63 million. Figure 32 shows the annual rates of growth for the rural and urban populations. From 1995 onwards, there is a clear trend towards continual growth of the urban population. As the natural growth rate of the rural population remains positive this is attributable to urbanisation. 
Figure 32: Rural Urban Annual Growth Rates

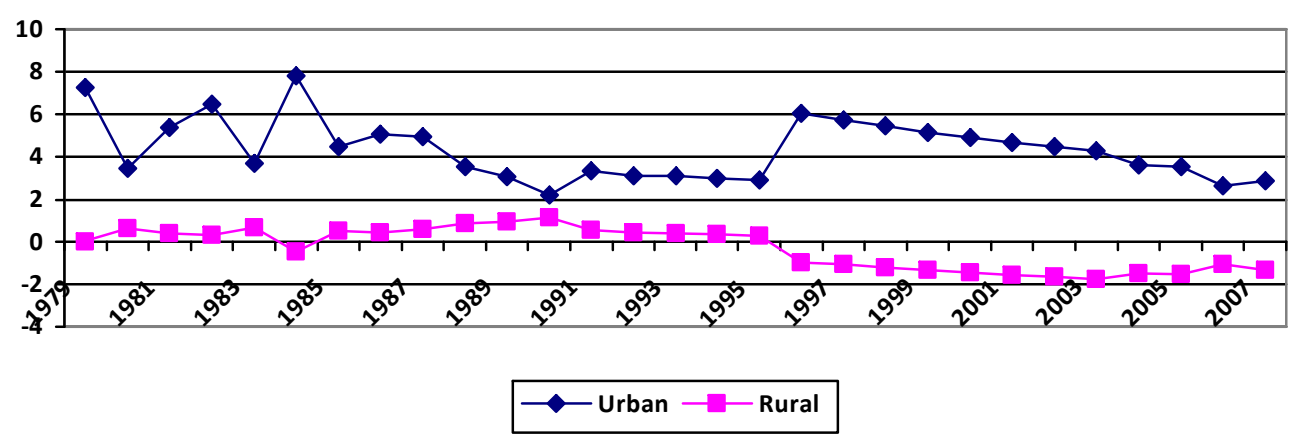

Source: Calculated from data in China Population and Employment Statistics Yearbook 2008, p.5

This rapid urbanisation has allowed China to close the urbanisation gap with the world from $20 \%$ in 1978 to around $5 \%$ today (see figure 33). As with China's large contribution to global poverty alleviation and economic growth, China accounts for much of the global rise in urbanisation.

Figure 33: Urbanisation for the World and China (1975-2007)

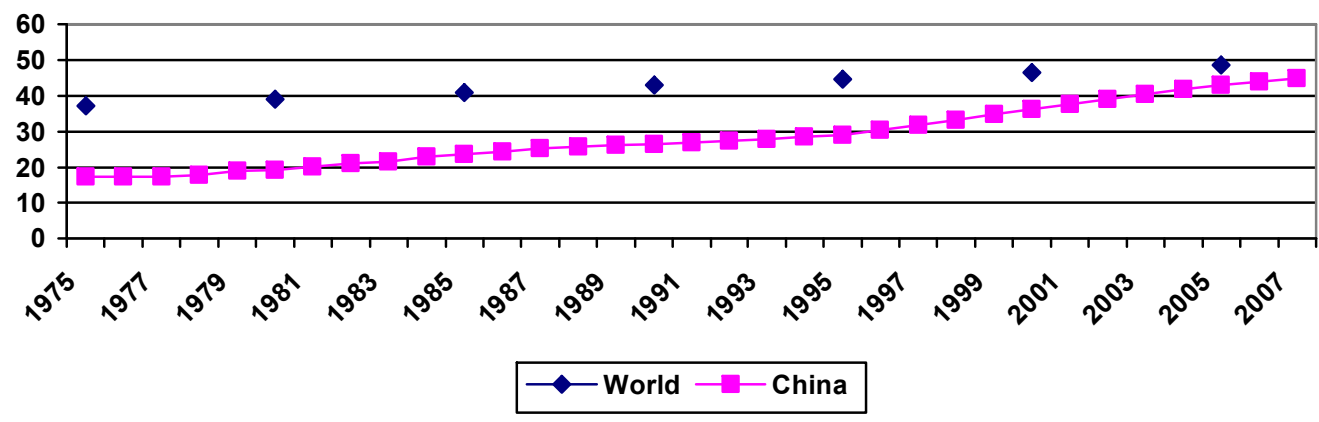

Source: United Nations and China Population and Employment Statistics Yearbook 2008, p.5

China's urbanisation growth has been remarkably stable considering the continuing economic forces attracting rural migrants to urban areas. For example, the overall annual wage has grown at a faster rate than the average wage in agriculture. The average wage in agriculture was half of the overall average wage in 2003. This had dropped to $44 \%$ in 2007 . The average wage in manufacturing and construction remains near $80 \%$ the overall average wage. These industries are accessible to nongmingong. This shows a considerable and growing economic rationale for migration to urban areas. 
Figure 34: Average Wage by Selected Sectors (Yuan)

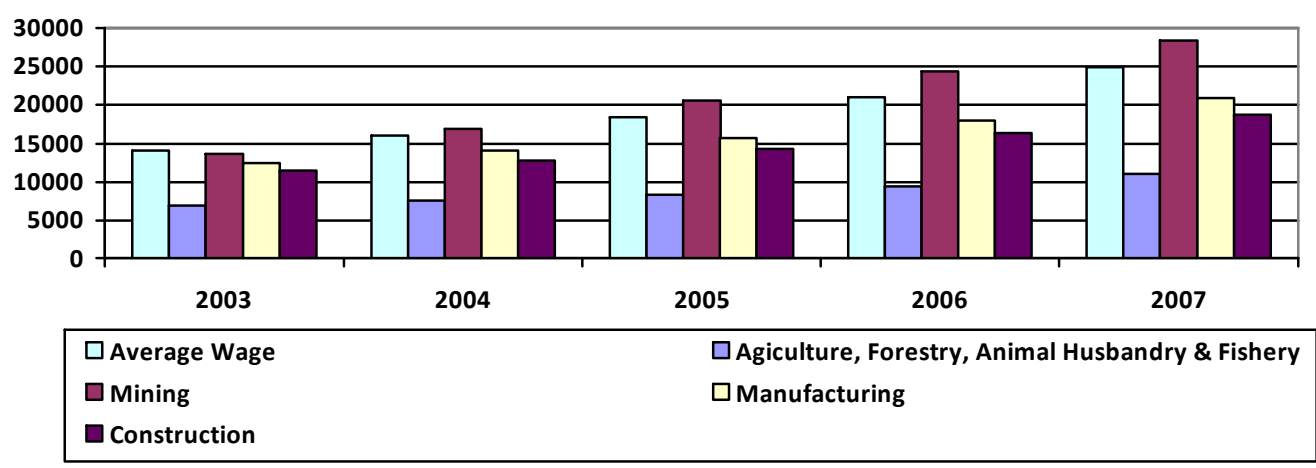

Source: China Population and Employment Statistics Yearbook 2008, p.31

Moreover, there are varying levels of economic development and urbanisation between the east and west. The level of economic development in central and western regions is far behind the east. Over half of China's urban population resides in the east (see figure 35). Whilst the total eastern population is larger than either the western or central population, the proportion of people classified as urban in the east is higher than in the centre or west. Whilst all regions continue to urbanise the rate in the east has remained $11-12 \%$ higher than the centre and $17-18 \%$ higher than in the west (see figure 36 ).

Figure 35: Urban Population by Region (Millions)

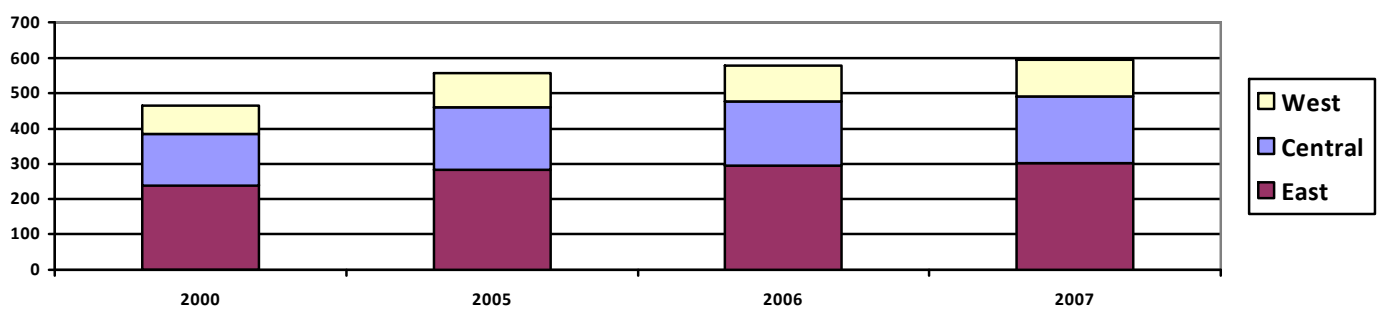

Source: Calculated from 2001-2008 China Statistical Yearbooks www.stats.gov.cn/

Figure 36: Urban Population by Region (Percentage)

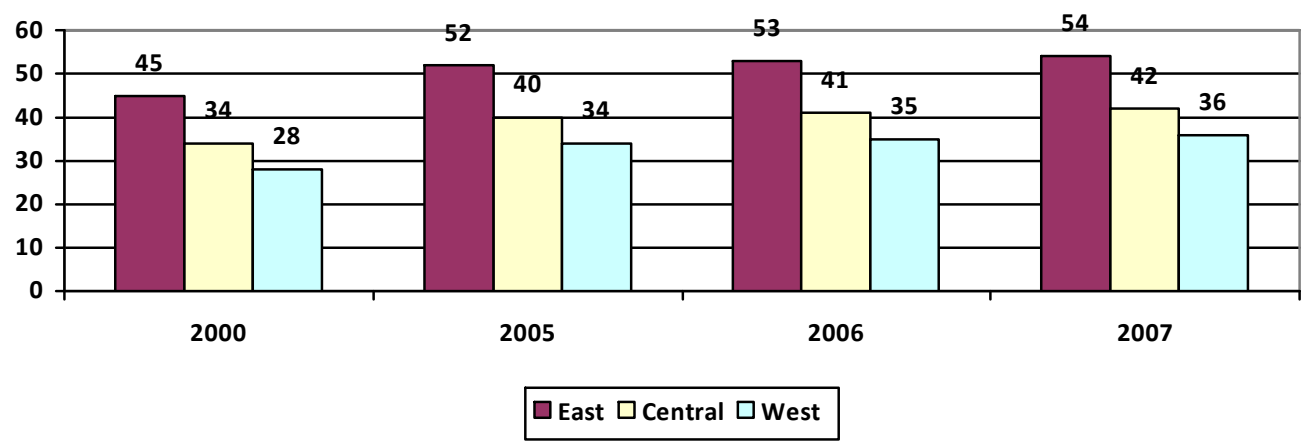

Source: Calculated from 2001-2008 China Statistical Yearbooks www.stats.gov.cn/ 
The economic pull of the east has led to greater rural to urban migration there. Whilst strict hukou transfer conditions continue to bar most rural to urban migrants from hukou residency in these areas a significant number of migrants are residing and working in urban areas as temporary permit holders or 'floaters'. Figure 37 shows survey estimates of the proportion of non-hukou residents in each region as a percentage of the total regional population. ${ }^{471}$

Figure 37: Non-Hukou Holders as a Percentage of the Regional Population 1996-2007

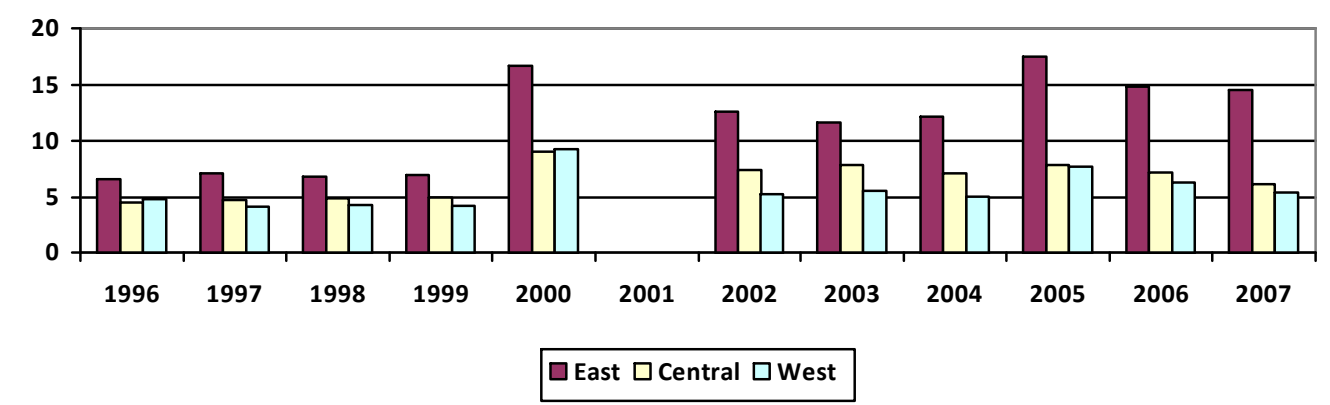

Source: Calculated from 1997-2008 China Statistical Yearbooks www.stats.gov.cn/

Between 2000 and 2005 the proportion of the regional population without permanent hukou in the central and western regions actually decreased by about $1 \%$. Whereas, in the east it nearly increased by $1 \%$ (see figure 38). This was a real decline of 7 million non-hukou residents in the centre and west and a real growth of 10 million in the east (see figure 39).

Figure 38: Non-Hukou Holders as a Percentage of the Regional Population 2000, 2005

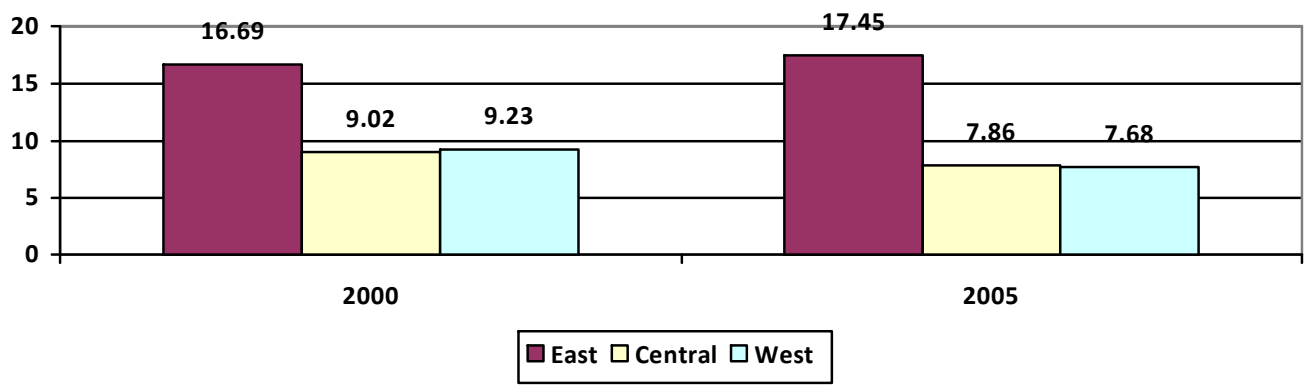

Source: Calculated from 2001-2008 China Statistical Yearbooks www.stats.gov.cn/

${ }^{471}$ The data from 2000 comes from the 2000 Census whereas all other years are calculated from small 1\% samples. 
Figure 39: Regional Population of Non-Hukou Holders in 2000 \& 2005 (millions)

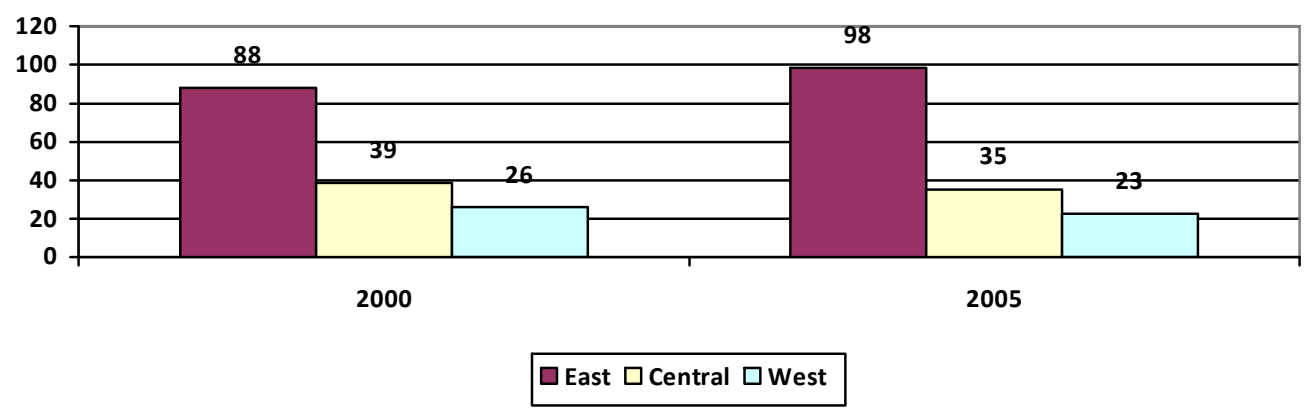

Source: Calculated from 2001 \& 2006 China Statistical Yearbooks www.stats.gov.cn/

NBS data from the 2000 Census show 144 million people residing outside of their permanent hukou location. 102 million of these non-hukou residents had permanent hukou residence within the same province (50 million in the east and 50 million in the centre and west). Of the 42 million migrants residing in provinces different from their permanent hukou residency, 34 million (79\%) resided in provinces in the east. This is evidence that China's population mobility is both more prevalent in the eastern region where economic development is more advanced and that the vast majority of interprovincial migrants originate from the centre and the west and are destined for the east.

Figure 40: Permanent Hukou Location of Non-Hukou Population by Regions in 2000 (millions)

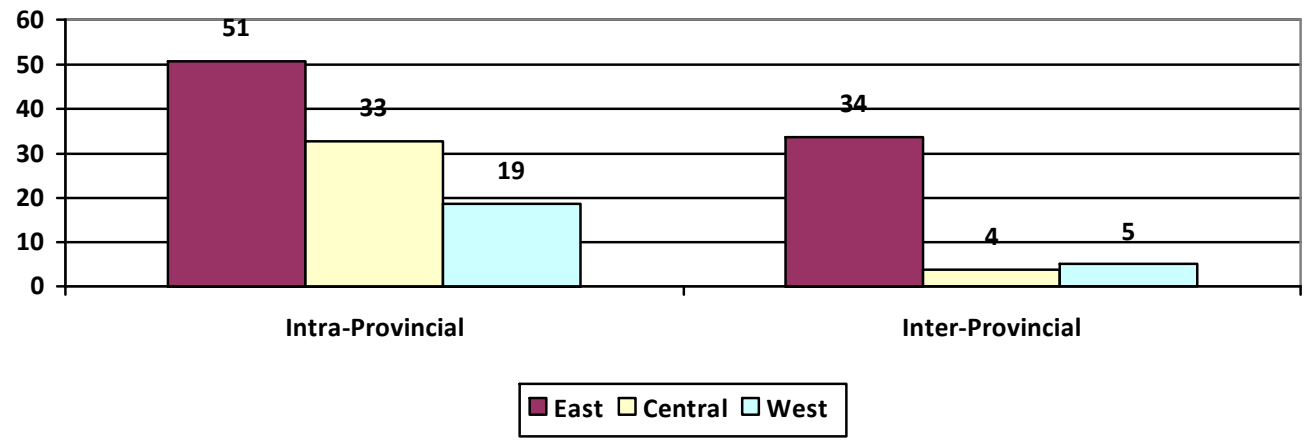

Source: Calculated from 2001 China Statistical Yearbook www.stats.gov.cn/ 
Figure 41: Permanent Hukou Location of Non-Hukou Population by Regions in 2000 (\%)

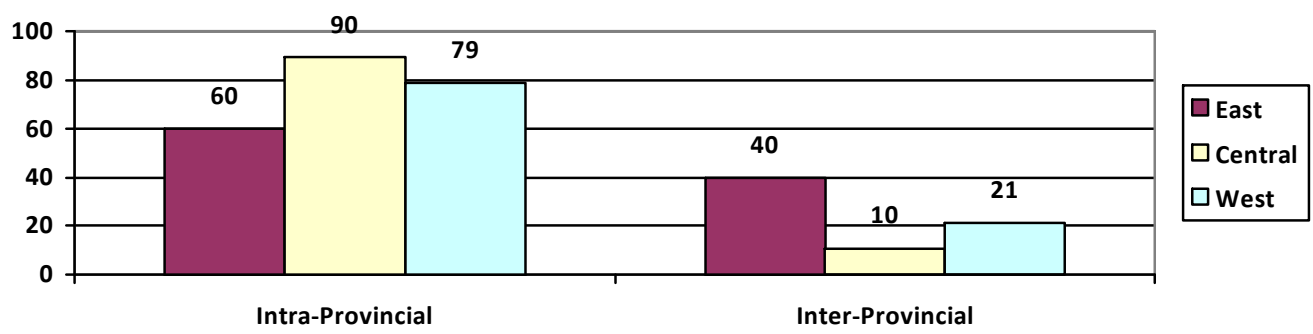

Source: Calculated from 2001 China Statistical Yearbook www.stats.gov.cn/

This has created greater levels of urbanisation in the more developed east. Whilst the growth of the temporary population, especially inter-provincial migrants, is particularly high in the east the level of non-agricultural hukou is as well. The level of nonagricultural hukou rises as the level of urbanisation rises (see figure 42). This suggests a degree of reflexivity to the size of the temporary population by local governments. However, there remains a notable gap between urbanisation and non-agricultural hukou over all regions in China, irrespective of rate of urbanisation. Only Xinjiang has a higher rate of non-agricultural hukou than level of urbanisation. Urbanisation is on average $10 \%$ ahead of the rate of non-agricultural hukou across the 31 regions of varying urbanisation levels. This suggests hukou transfer is set below the level of urbanisation to slow the speed of rural to urban transfer.

Figure 42: Urbanisation by Non-Agricultural Hukou over 31 Regions (2007)

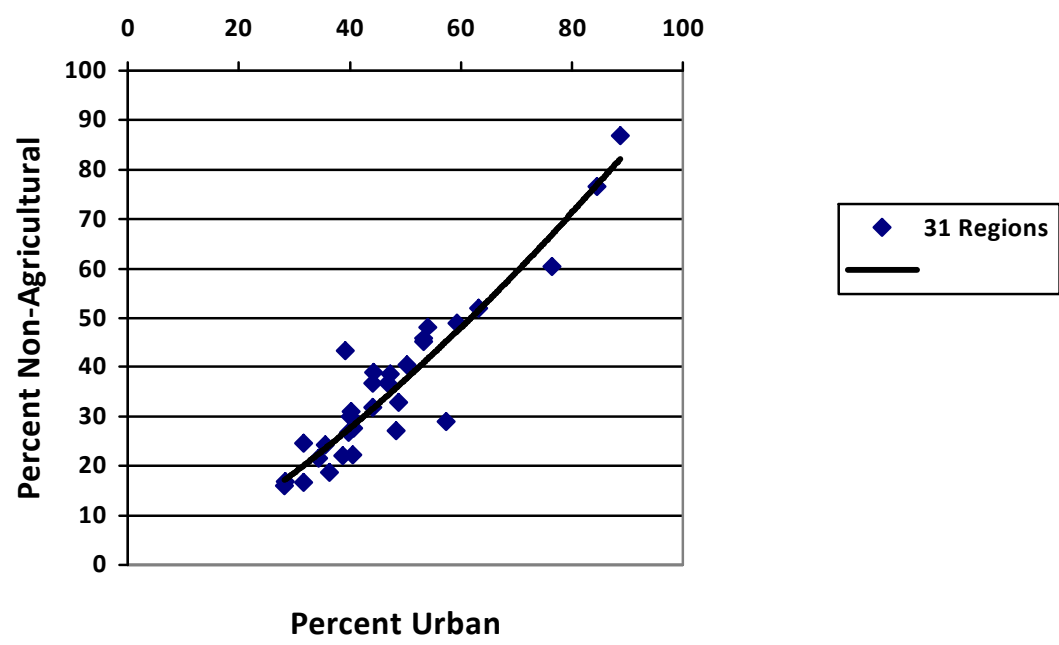

Source: Data from China Population and Employment Statistics Yearbook 2008, p.37 \& p.293 
A similar trend is found when analysing the location of China's non-agricultural population. Over 218 million live in the heavily populated east, whilst the centre accounts for 139 million and 74 million in the west (see figure 43). Again, whilst the east's population is the largest of all three regions it still has a proportionately higher number of non-agricultural residents. Figure 44 shows the non-agricultural/agricultural ratio was highest in the east in 2007. Table 14 shows a comparison of urbanisation rates and hukou type by region in 2007. The east is both more urbanised and has a higher proportion of non-agricultural hukou holders.

Figure 43: Registered Agricultural \& Non-Agricultural Population by Region in 2007 (millions)

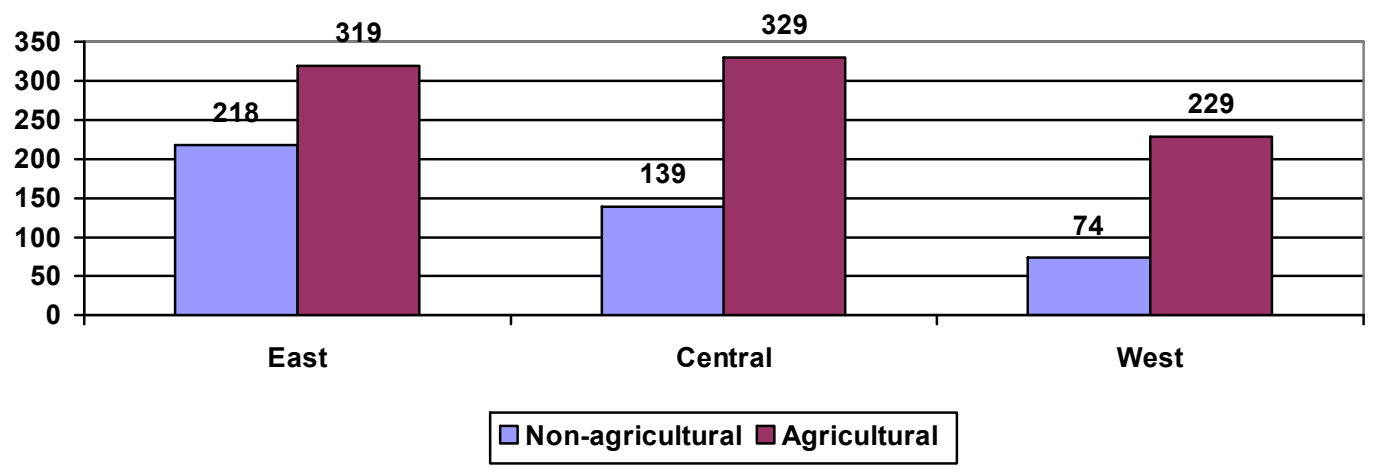

Source: Calculated from China Population and Employment Statistics Yearbook 2008, p.293

Figure 44: Registered Agricultural \& Non-Agricultural Population by Region in 2007 (\%)

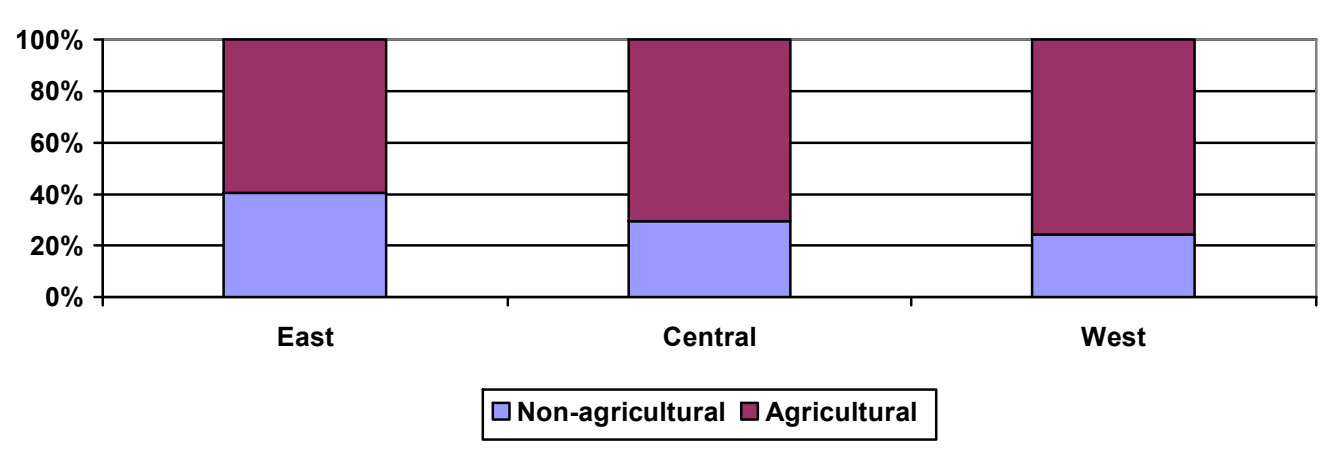

Source: Calculated from China Population and Employment Statistics Yearbook 2008, p.293 
Table 14: Urbanisation and MPS Hukou Type by Region in 2007

\begin{tabular}{|c|c|c|c|c|c|c|c|c|}
\hline & \multicolumn{2}{|c|}{ National } & \multicolumn{2}{|c|}{ East } & \multicolumn{2}{|c|}{ Centre } & \multicolumn{2}{|c|}{ West } \\
\hline $\begin{array}{l}\text { Population } \\
\text { (NBS) }\end{array}$ & $\begin{array}{c}1321 \\
(1300)\end{array}$ & & 566 & & 443 & & 291 & \\
\hline $\begin{array}{c}\text { Urban } \\
\text { Population }\end{array}$ & 594 & $45 \%$ & 304 & $54 \%$ & 186 & $42 \%$ & 105 & $36 \%$ \\
\hline $\begin{array}{c}\text { Rural } \\
\text { Population }\end{array}$ & $\begin{array}{c}727 \\
(705) \\
\end{array}$ & $55 \%$ & 262 & $46 \%$ & $\begin{array}{c}257 \\
(279) \\
\end{array}$ & $58 \%$ & 186 & $64 \%$ \\
\hline $\begin{array}{l}\text { Population } \\
\text { (MPS) }\end{array}$ & 1309 & & 537 & & 468 & & 303 & \\
\hline $\begin{array}{c}\text { Non- } \\
\text { Agricultural }\end{array}$ & 431 & $33 \%$ & 218 & $41 \%$ & 139 & $30 \%$ & 74 & $24 \%$ \\
\hline $\begin{array}{l}\text { Agricultural } \\
\text { Population }\end{array}$ & 878 & $67 \%$ & 319 & $59 \%$ & 329 & $70 \%$ & 229 & $76 \%$ \\
\hline
\end{tabular}

Source: Calculated from China Population and Employment Statistics Yearbook 2008, p.5 \& p.293

Level of economic development, level of urbanisation and proportion of the population with non-agricultural hukou status are all higher in the east, as is the relative proportion of people residing outside of their hukou status. Inter-provincial migrants almost exclusively reside in the east. This suggests a positive correlation between the level of urbanisation, size of the temporary population and degree of hukou transfer. The proportion of the population with non-agricultural hukou is also relatively high in the east on two further indicators of urbanisation, the city level and the town level. 55\% of residents in cities in the east have non-agricultural hukou, compared to $48 \%$ and $45 \%$ in the centre and west (see figure 45 ). At the town level $26 \%$ of residents have nonagricultural hukou in the east whilst only $21 \%$ and $20 \%$ do in the centre and west (see figure 46). Half of the east's non-agricultural hukou holders at the town level are in counties meaning the other half are in towns at the city level (see figure 47).

Figure 45: Non-Agricultural and Agricultural Population in Cities by Region (2007, total 619m)

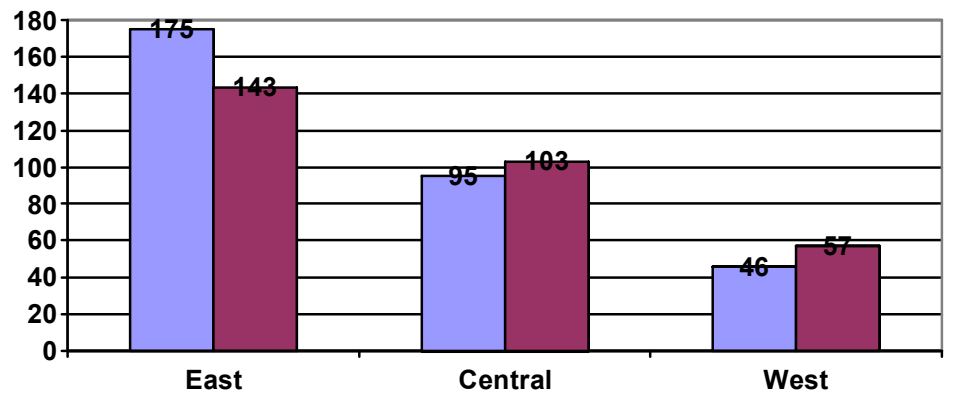


Figure 46: Non-Agricultural and Agricultural Population in Towns by Region (2007, total 762m)

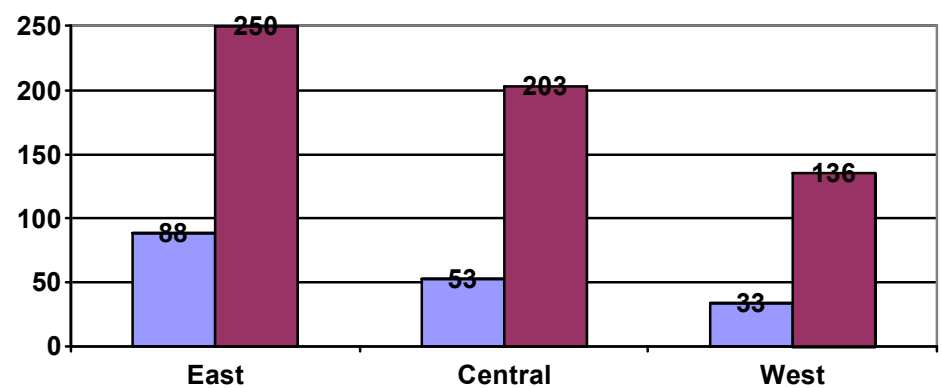

$\square$ Non-Agricultural

$\square$ Agricultural

Source: Calculated from China Population and Employment Statistics Yearbook 2008, p.296

Figure 47: Non-Agricultural and Agricultural Population in Counties by Region (2007, total 689m)

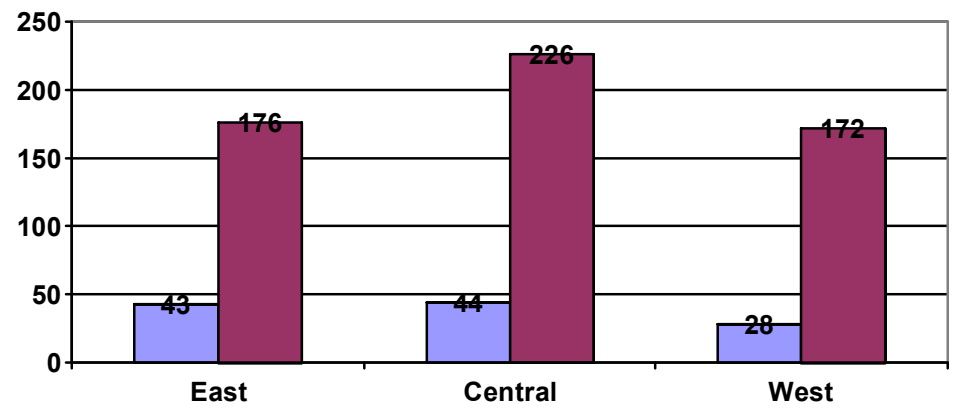

Source: Calculated from China Population and Employment Statistics Yearbook 2008, p.295

Of a total of 431 million non-agricultural hukou holders $73 \%$ reside in cities $(316 \mathrm{~m})$ and $27 \%$ in counties $(115 \mathrm{~m}) .74 \%$ reside in towns $(174 \mathrm{~m}) .{ }^{472}$ Of the 878 million agricultural hukou holders $35 \%$ reside in cities $(303 \mathrm{~m})$ and $65 \%$ in counties $(574 \mathrm{~m}) .67 \%$ reside in towns $(589 \mathrm{~m})$. At the city level non-agricultural hukou is distributed differently across the varying city sizes. Over three quarters of the city population $(508 \mathrm{~m})$ live in cities smaller than 3 million in size (see figure 48). Chinese cities do not correlate to western cities. In the west cities are defined as urban areas through population density and urban infrastructure measures. In China, cities are a government level that incorporates urban city areas, towns and even rural areas within their boundaries. Therefore, the total city population of 619 million is not comparable to the level of urbanisation. ${ }^{473}$

\footnotetext{
472 Towns are present in both counties and cities.

${ }^{473}$ Urbanisation in China is recorded as the rate of people living urban lives in cities and towns. There is little information on how this data is measured.
} 
Figure 48: Distribution of City Population across Varying City Sizes (millions; total 619m)
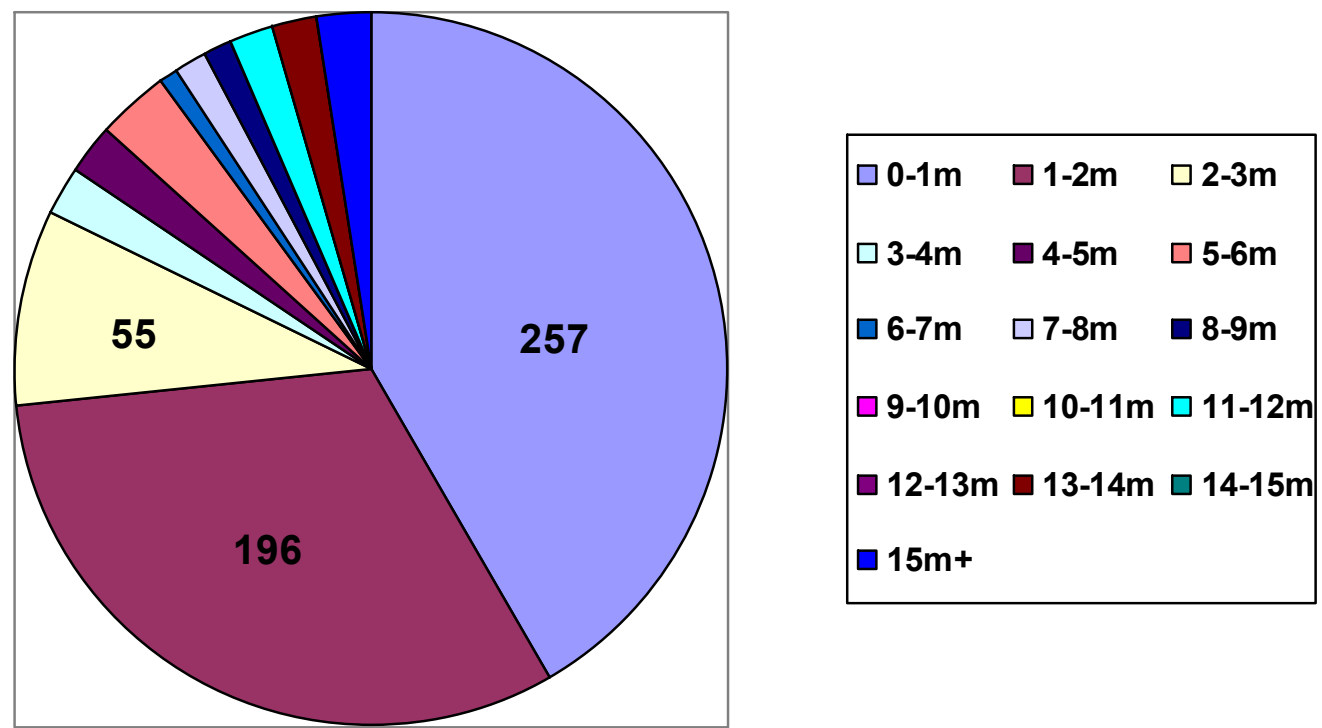

Source: Calculated from China Population and Employment Statistics Yearbook 2008, pp.297-304

Whilst nationally there are 619 million people in Chinese cities of which 316 million (51\%) have non-agricultural status and 303 million (49\%) do not, omitting data from cities smaller than 3 million in size gives a city population of 110 million of which 85 million (77\%) have non-agricultural status and 25 million (23\%) do not. The majority of the population of the large cities (over 3 million) have non-agricultural status (Chongqing, China's largest city, is an interesting exception; see figure 49). However, 509 million people ( $82 \%$ of the total city population) live in cities that are below 3 million in size. $55 \%$ of these people do not have non-agricultural hukou (see figure 50). 453 million people (73\% of total city population) live in cities that are below 2 million in size. $57 \%$ of these people do not have non-agricultural hukou. This suggests that larger cities have a higher rate of non-agricultural hukou than smaller cities. 
Figure 49: Non-agricultural Hukou Status in Cities 3-16 Million (110 million total)

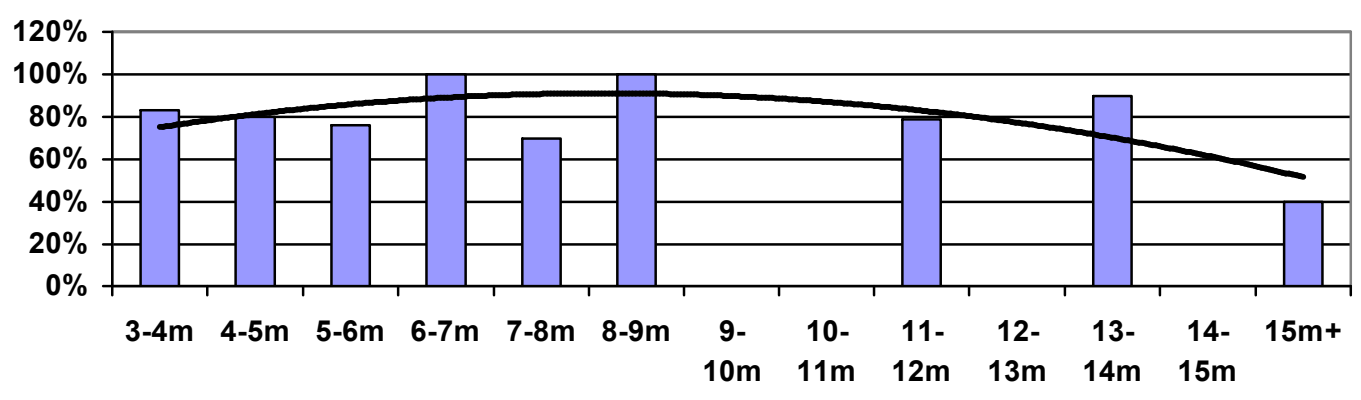

$\square$ Non-Agricultural Hukou $\longrightarrow$ Poly. (Non-Agricultural Hukou)

Source: Calculated from China Population and Employment Statistics Yearbook 2008, pp.297-312

Figure 50: Non-Agricultural Hukou in Cities Smaller than 3 Million (509 million total)

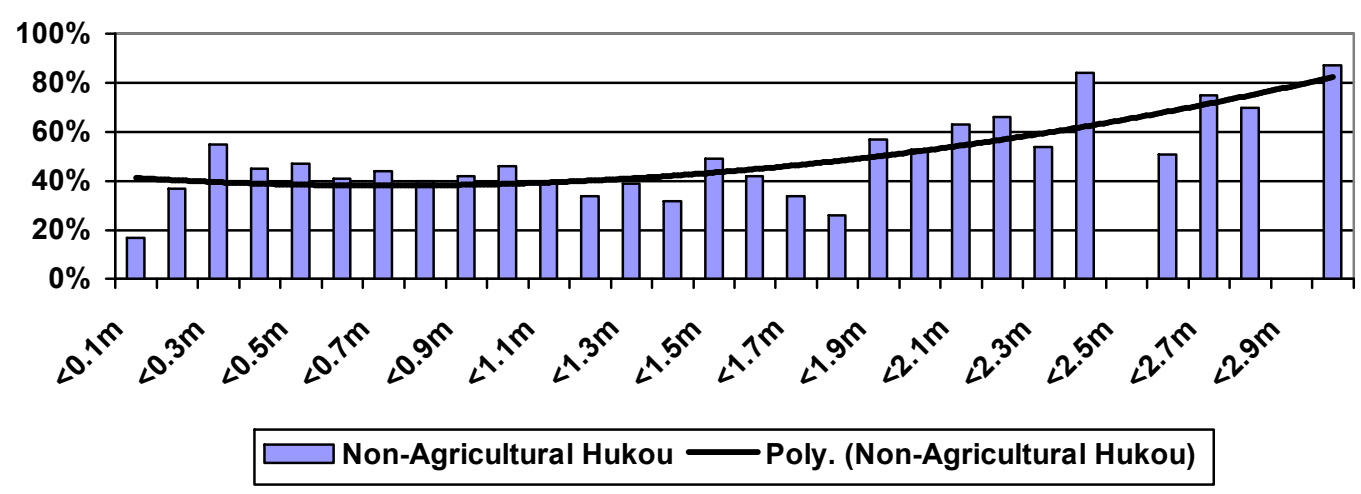

Source: Calculated from China Population and Employment Statistics Yearbook 2008, pp.297-312

Just as the average wage is correlated with the level of urbanisation (see figure 51), so too is the percent with non-agricultural hukou. In regions where non-agricultural hukou is more prevalent the average wage is higher (see figure 52).

Figure 51: Average Wage of Staff \& Workers by Urbanisation in 31 Regions

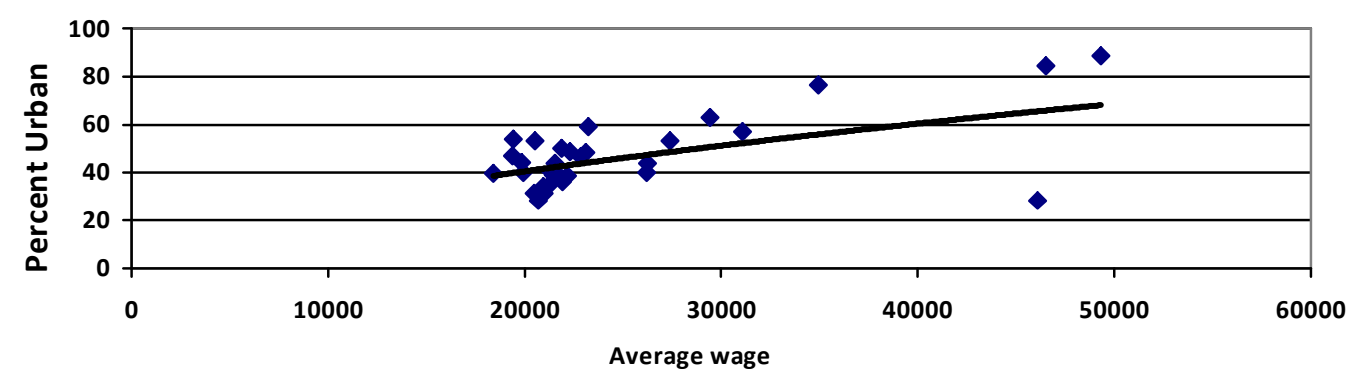

Source: Calculated from China Population and Employment Statistics Yearbook 2008, p.32 \& p.37 
Figure 52: Average Wage of Staff \& Workers by Non-Agricultural Hukou in 31 Regions

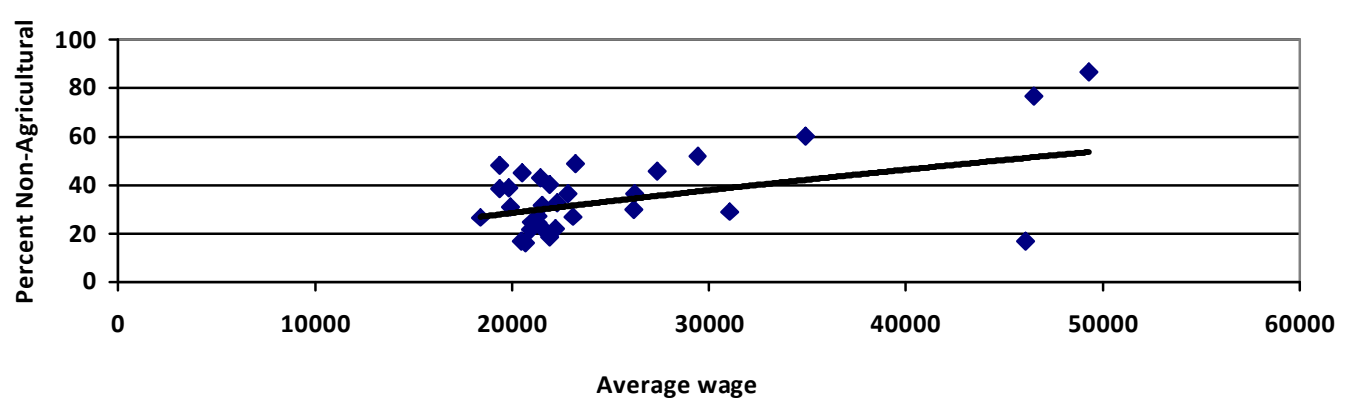

Source: Calculated from China Population and Employment Statistics Yearbook 2008, p.32 \& 293

As the level of urbanisation and non-agricultural hukou status is both higher in the east, we can assume as urbanisation rises so too do non-agricultural rates (see figure 53). This shows a relationship between economic development, migration (especially nonhukou migration) and hukou type.

Figure 53: Urbanisation and Non-Agricultural Hukou in regions (2007)

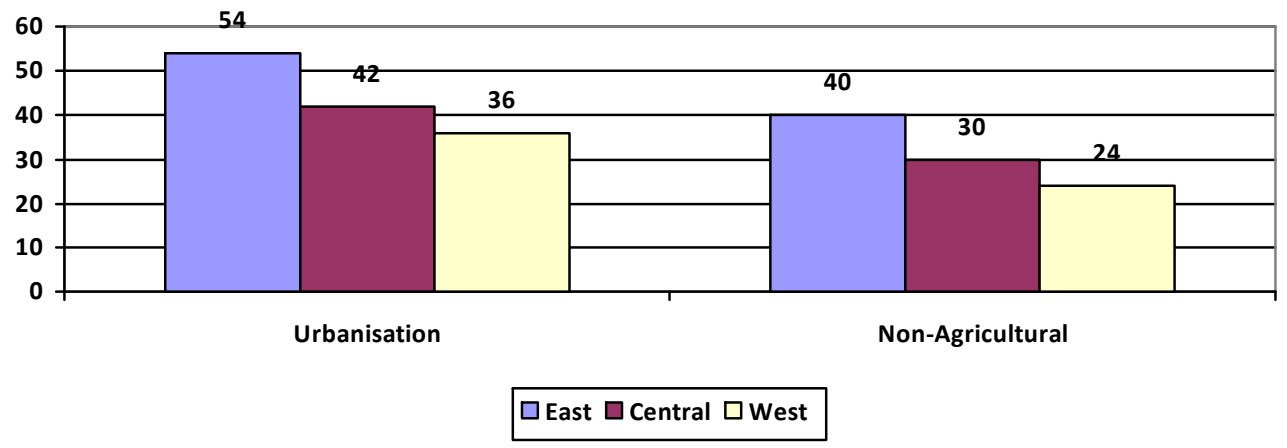

Source: Calculated from China Population and Employment Statistics Yearbook 2008, p.293

Therefore, hukou transfer remains a significant tool utilised by local governments to slow the rate of urbanisation by decreasing the desirability of permanent migration. Non-agricultural hukou rates are set roughly $10 \%$ below the level of urbanisation in each region. Economic development in the east far outstrips that of the centre and west. Because of this more non-hukou migrants are present in the east (both in real terms and as a proportion of the population) and this has led to greater non-agricultural hukou rates at the regional level, city level and town level suggesting a degree of local government reflexivity to temporary population pressures. 


\subsection{Strengthening the Party-State}

The overall objective of the huji institution is to strengthen the party-state. This is done through the first three objectives, prioritising economic development, maintaining social stability and managing and restricting migration and urbanisation. In fact, these huji objectives are all interrelated. By adapting the huji institution to meet the first three objectives in the new socio-economic environment central and local authorities strengthen their governance and the rule of the party-state. In this sense, the huji institution plays an important role shaping Chinese modernity. As political arrangements in China increasingly draw their legitimacy from sustained socioeconomic growth the huji institution has prioritised this aim above the more traditional economic planning functions and even to some extent security and urbanisation functions. China's status quo huji institution has solidified with profound economic benefits but also increasing political tension. The huji institution is increasingly being questioned by many migrants excluded from hukou transfer. This emerging civic rights movement is questioning the legitimacy of huji regulations and the measures central and local authorities use to slow migration and urbanisation, maintain social stability and prioritise economic development. Whilst not yet reaching the level of influence business interests exerted on the evolving huji status quo over the reform era, this civic rights movement is increasingly pressuring government for reforms based on a fundamental right to equality.

\subsubsection{An Emerging Civic Rights Movement}

The introduction of temporary permits in 1985 and the following regulations that improved official's management and control of the temporary/non-hukou population provided China's booming service sector with the necessary labour force whilst concurrently maintaining strict transfer policies and positive discrimination for the 
permanent urban population. The advent of temporary labour migrants unleashed China's rural labour which in combination with the urban labour force created an unprecedented period of modernisation and economic development. The economic forces so important for the early adaptation of the huji institution in the 1980s no longer exerted the same pressure for reform. The impetus for reform now came predominantly from those living and working in urban areas but excluded from local urban or nonagricultural residency. This applied to both rural migrants holding non-local and agricultural hukou and to local agricultural hukou holders. Migrants to urban centres continue to be excluded from the now weakened but still significant 'urban rationing regime'. Nongmin that had their land expropriated by local government faced the injustice of losing the benefits of agricultural hukou status without gaining the benefits of non-agricultural hukou status in their local region. Both groups form a newly created institutional category of urban status associated with low-end employment and socioeconomic disadvantage. Calls to reform discriminatory policies in employment, education, health, social security and housing have been followed by some reduction in hukou discrimination, but as the previous sections show, hukou status still largely determines socio-economic opportunity and hukou transfer remains tightly managed by local and central government who prioritise economic development and social stability above civic equality. ${ }^{474}$

The basis of the emerging civic rights movement is the principle of equality enshrined in the constitution, Chinese law and various international treaties China is signatory to. The PRC Constitution states it is the highest law in the land and that all PRC citizens are free and equal before the law. All citizens should receive social security and state welfare where needed and all citizens have the right and duty to receive compulsory

\footnotetext{
${ }^{474}$ The argument being that economic development and social stability are preconditions for civic equality.
} 
education. The PRC Education Law states PRC citizens have equal opportunity to receive an education. The PRC Civil Servant Law states all positions will be filled through equal competition. China has signed but not ratified the International Covenant on Civil and Political Rights and is signatory to a number of other UN declarations protecting the right to freedom of movement for all citizens within the state. Existing huji regulations contradict some of these legal principles. In particular, ZHANG Hengshan argues recent reforms do not meet the standard of free movement and settlement because they are not well adhered to, they target a select group of high achievers and the institution is plagued by local authority corruption and inequality. ZHANG argues for incremental reform to prevent a 'flood of migrants' whilst moving towards ultimately protecting Chinese citizens' fundamental right to freedom of migration. $^{475}$

This emerging civic rights movement is also an important influence on huji policy. However, aside from a rising number of 'social disturbances' the focus of much of this nascent civic rights movement has been labour advocacy. Examples include the Little Birds group who formed a hotline to help migrant workers in the construction industry claim unpaid wages in $2008 .{ }^{476}$ Another is the Hong Kong based China Labour Bulletin, a monitoring and research organisation founded in 1994 by labour activist Han Dongfang. ${ }^{477}$ The recent Labour Law and many other new laws in China have also significantly improved the legal rights of the non-hukou population although the implementation of those rights remains problematic. Local governments in particular have increasingly been under pressure to improve transparency, accountability and

\footnotetext{
${ }^{475}$ Zhang Hengshan 张恒山. "关于公民迁徙自由的立法" [Legislation Regarding Freedom of Migration ]. In 《庆祝中德建交三十周年 “中国与 WTO” 研讨会, 慕尼黑对话》[Celebrating 30 Years of Diplomatic Relations between China and Germany, 'China and the WTO']. 慕尼黑 [Munich]: 汉 斯 - 赛德尔基金会共同举办 [Hanns Seidel Foundation], 2002.

${ }^{476}$ Little Bird 小小鸟. 《关于我们》[About Little Bird]. 北京 [Beijing]: 小小鸟打工互助热线 [Little Bird Labour Help Hotline] http://www.xiaoxiaoniao.org.cn/index.htm, 2008.

${ }^{477}$ China Labour Bulletin, "Home," (Hong Kong: China Labour Bulletin http://www.clb.org.hk/en/, 2009).
} 
professionalism in huji management. But again, serious problems remain. Local governments still control hukou transfer strictly and rely heavily on the huji institution as a means to influence migration and urbanisation, to promote economic development and maintain social stability. As urbanisation increases pressure for reform from the growing new-migrant population also increases. Reform experiments are a sign authorities are taking seriously calls for an end to hukou dualism (agricultural/nonagricultural), high conditions on hukou transfer and urban discrimination of local agricultural hukou holders and migrant workers. So too are many of the new laws in China, particularly the Labour Contract Law (2008). The emerging civic rights movement calls for greater political and economic equality in urban areas and from this perspective huji institutional reform has stalled in recent decades. However, from the perspective of the central and local government planners, huji reform remains on track to act as a break on uncontrolled urbanisation so as to try to prevent rapid urbanisation and greater social instability which could harm the governance of the Party-State.

\subsubsection{Incremental Political Reform}

"It took advanced countries over a hundred years to complete urbanization and primitive accumulation. Now these countries begin to view human rights as the highest good. This [emphasis on human rights] has become a trend. With this trend, China begins its urbanization and primitive accumulation. If we completely abide by these human rights requirements, eighthour workday, and so on, will we be able to accomplish primitive accumulation? Will our enterprises be able to develop? This problem is a big contradiction for China. We would like to avoid some of the paths travelled by advanced countries and [go through the process with] less cost, blood, and sweat, but we also feel that the economic law is hard to bend. China used to have a very good social system, admired around the world. But the result was that our economy moved very slowly, far below the world average.... What we should do is to do our best to reduce the negative side during this stage [of primitive accumulation]. The situation we see today is surely better than that in Marx's days..... Our task is to clear the path for the historically irresistible tide and reduce the cost of development to a minimum. ${ }^{478}$

In 2009 the MPS outlined the aims of reform of the huji institution. These were, to establish a rural/urban unified hukou registration system, broaden restrictions on ' $h u k o u$ transfer' and guide rational and orderly population flows. These aims reflect measures

\footnotetext{
${ }^{478}$ Xie Lihua, 1999, National Forum on Issues about Women Migrant Workers' Rights and Interests, cited in Hairong Yan, New Masters, New Servants: Migration, Development and Women Workers in China (Durham and London: Duke University Press, 2008), p.243.
} 
trialled in previous reform experiments. Even if they are implemented, such moves would do little to reduce hukou discrimination and the continued use of the huji institution to meet economic, security and migratory objectives. The MPS still refuse to outline any kind of reform timetable arguing it is impossible to quickly abolish the huji institution due to disparity between rural and urban areas. ${ }^{479}$ They continue the reform rhetoric but evidence suggests that other than the introduction of temporary permits in 1985, past reforms have been limited in scope. The possibility of establishing a "huji law' in future has been a proposal since the turn of the century. ${ }^{480}$ Huji reform is indeed moving slowly. As of 2009, the Central People's Government of the People's Republic of China states the legal basis for huji regulations is the Nationality Law of the PRC (1980), the PRC Resident Identity Card Law (2004), the PRC Temporary Resident Identity Card Management Measures (2005), and the Job Specification for Processing Hukou [and] Identity Cards for Residents (1998). ${ }^{481}$ This central government portal also provides a list of advice for citizens regarding hukou regulations. ${ }^{482}$ The advice directs citizens to change their hukou status when changing their place of permanent residence and states that government transfer policies include provisions for, cadres, employees and students, military and their families but that each region has its own settlement procedures. The central government site and related regulations do little to illuminate hukou transfer and show it is still subject to strict control and secrecy by local and central authorities.

\footnotetext{
${ }^{479}$ Xinhua News Agency 新华社. 《公安部等 14 个部委正协商户籍管理制度改革》[Mps and 14 Ministries and Commissions Negotiating Huji Management System Reform]. 成都商报 [Chengdu Business News], 2008.

${ }^{480}$ See: China Popin 中国人口信息网。《全国政协委员呼吁尽快制定适应发展 ‘户籍法”》[National Political Consultative Conference Committee Appeal to Establish a 'Huji Law' Suitable for Development as Quickly as Possible]. 中国人口与发展研究中心[China Population and Development Research Centre], http://www.cpirc.org.cn/news/rkxw_gn_detail.asp?id=415.

481 《中华人民共和国国籍法》; 《中华人民共和国居民身份证法》; 《中华人民共和国临时居民身 份证管理办法》; 《办理户口、居民身份证工作规范》. For more details see: The Central People's Government of the People's Republic of China 中华人民共和国中央人民政府.《法律依据》[Legal Basis].中国政府门户网站 [Chinese Government Internet Portal], http://www.gov.cn/banshi/200505/30/content_2029.htm, 2009.

482 ․ 《户籍》[Huji]. 中国政府门户网站 [Chinese Government Internet Portal], http://www.gov.cn/banshi/gm/huji.htm, 2009.
} 
From the perspective of strengthening the governance of the party state, the huji institution provides local governments the power to reduce rural to urban migration through strict hukou transfer policies and temporary permits. This then gives local government some power to incrementally increase the size of both the permanent and temporary populations in line with levels of economic development and the creation of urban employment. The huji institution allows the state to exert some influence over the size of the temporary population that they fear without restriction would outstrip employment opportunities in the emerging tertiary and secondary sectors. The rural population remains large and underemployed in the primary sector increasing 'push' forces of rural to urban migration. Central and local authorities fear free migration and settlement would increase urban unemployment and create social instability in urban areas, increase the crime rate, drive down already low wages and increase the likelihood of sweatshop labour conditions becoming more prevalent. As it is, the growth of China's cities has created a significant task for local authorities. Therefore, evidence suggests authorities have decided to incrementally reform the huji institution to allow urban centres time to adapt to the new socio-economic conditions and to grant urban authorities the power to incrementally raise urbanisation rates in line with economic development. This type of management of migration and urbanisation is unprecedented in a rapidly developing state with growing rural/urban and east/west economic disparity and clearly is an important feature of the Chinese development mode. Balancing huji objectives with incremental liberalisation to meet increasing calls for civic equality is one of the most important challenges for the state steering China's modernist project. Finding other means to govern without the use of the huji institution is hampered by the extreme urbanisation pressures brought about by rural-urban and east-west disparity and a commitment to existing huji institution objectives. 


\subsection{Conclusion}

This case study has found that the huji institution has been significantly adapted to meet the requirements of a rapidly changing socio-economic environment. The actual functioning of the huji institution was significantly different in 2007 than in 1978. These changes reflect the state's adaptation primarily to the new economic rationales of the reform era but also increasingly to calls for greater civic equality. However, this case study has also found that whilst the huji institution now functions very differently there is also a significant amount of continuity in its objectives. The state's ability to meet huji objectives has in fact been strengthened over the reform era. This explains the type of reform that has occurred and why the huji institution has not been dismantled as occurred in Russia, Korea, Taiwan and Japan. The survival of the huji institution over the reform period is due to the successful adaptation of the formal arrangements to meet the fundamental huji objectives. The demand for labour flows from the rapidly growing secondary and tertiary industries has been accommodated by the introduction of temporary permits. Efforts to maintain social stability through population governance and surveillance have been stepped up and modernised through new recording regulations and new technology. Localisation of hukou transfer has led to localised management of urbanisation and growth of the temporary and permanent population. A variety of methods have been introduced to regain control of these populations in the new mobile environment. But the emergence of a civic rights movement calling for freedom of migration and settlement and an end to state-subsidised positive discrimination remains a challenge to adapt to without reform of the fundamental huji objectives. The accommodation of this growing movement has proven harder than accommodation of demand forces for cheap labour. The next chapter looks at two case studies at the local level, Beijing and Shenzhen, and seeks to understand the key stakeholders and actors involved in reform of the huji institution in these regions. 


\section{Institutional Change in Beijing \& Shenzhen}

Beijing and Shenzhen present two very different cases of city development over the reform era. Beijing is an example of an established city with a steadily growing huji population. Local government recruits China's best and brightest through competitive hukou transfer policies. Since the 1980s, the growth of the 'temporary population' has facilitated low-end employment crucial to urban development. This 'temporary' labour migration is becoming increasingly permanent. This has led to some allocation of civic rights in education and insurance schemes but the fundamental institutional division remains. Shenzhen by comparison was a very small urban centre in 1978. It became a Special Economic Zone (SEZ) in 1980 and was designated one of China's most important manufacturing, assemblage and processing zones. Economic growth was made possible through a continuous flow of FDI and temporary contract labour. Shenzhen's population has grown rapidly over the reform era through steady huji growth and enormous growth in the size of the temporary population. As in Beijing, many of these temporary labourers are permanent in duration and increasingly calling for greater civic equality in their place of employment and residence. The diversity of huji application across these two case studies shows local governments have the tools to adapt the functioning of the huji institution to the differing local economic requirements.

\subsection{Case 2: Beijing}

The PLA entered Beijing in 1949 marking the fall of China's first republic. Beijing had been ruled by warlords after the 1911 revolution and was occupied by the Japanese Imperial Army during the Second Sino-Japanese War. As the capital of the new People's Republic, post-revolution Beijing represented the liberation and establishment of New China and an end to post-1840 humiliations at the hands of foreign powers. Beijing's national ministries and municipal government buildings embodied the new 
socialist modernist vision of state-led modernisation and development. After China emerged from its reactionary and isolated international position in the 1970s, Beijing became the site of a modern and flourishing economic community with extensive international links and a high standard of living compared to other regions of China. For this reason, Beijing hukou remain one of, if not the most, sought after credentials of contemporary China. Beijing's extensive public and private employment opportunities attract inward migration of both non-huji and huji categories. Control of hukou transfer and the introduction of temporary permits have been used to unleash economic growth in the capital whilst concurrently maintaining some influence over growth of both the permanent and temporary populations. It is now far easier than in dynastic times to enter the 'Forbidden City' but it remains exceptional to gain residency.

\subsubsection{The Beijing Huji Population}

The Beijing huji population grew steadily over the reform era from eight and a half million in 1978 to over twelve million in 2007 (see figure 54). The growth rate has been remarkably incremental and steady in light of urbanisation pressures and the size of the temporary population in Beijing. This section will look at the growth rate of the Beijing huji population, the level of urbanisation and the level of agricultural and nonagricultural hukou status. The actual rate of growth of the huji population has dropped considerably from a high of $9.7 \%$ in 1985 to sit consistently below $1 \%$ since 1998 (see figure 55).

Figure 54: Beijing Huji Population 1978 - 2007 (millions)

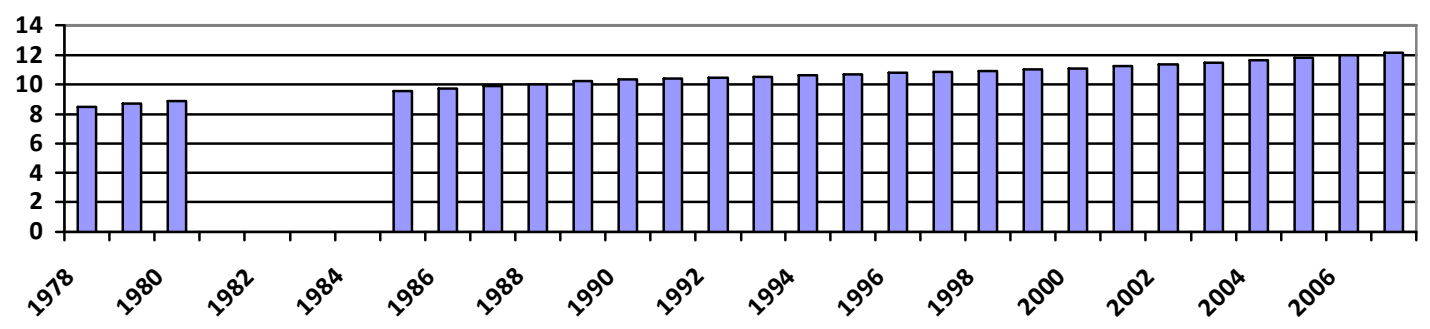

Source: 2008 Beijing Statistical Yearbook, www.bjstats.gov.cn/ 
Figure 55: Natural Growth Rate of the Population 1978-2004

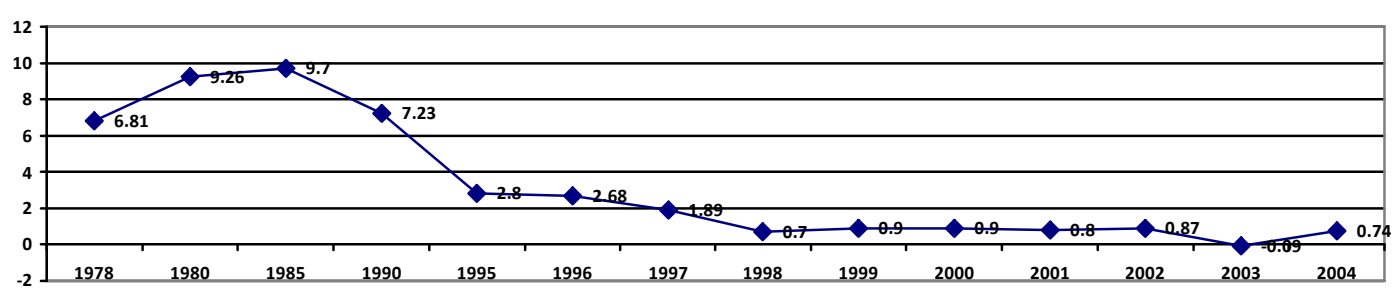

Source: Calculated from data from the 2005 Beijing Statistical Yearbook, www.bjstats.gov.cn/

The steady growth of the huji population can be attributed to two areas of huji governance, management of natural growth and management of non-natural growth. Natural growth refers to growth of the population from the birth rate being larger than the death rate. Non-natural growth refers to inward migration with hukou transfer being larger than outward migration with hukou transfer (see next section). Beijing's urban planning and enforcement of birth planning policies in combination with a rising economic cost to raising children has successfully helped slow the rate of growth of Beijing's huji population. The natural growth rate of the Beijing huji population has been close to zero in recent years. From 2003 to 2007, Beijing grew naturally at an annual average of only 14,000 people.

Natural growth rates have been significantly different across agricultural and nonagricultural hukou status. Natural growth of the non-agricultural hukou population has on average remained above replenishment. The rate of natural growth of the agricultural hukou population by comparison has consistently remained below replenishment (see figure 56). Non-agricultural hukou holders in Beijing have in recent years maintained a birth rate above the death rate, whereas, the death rate of agricultural hukou holders has outstripped the birth rate (see figure 57). 
Figure 56: Natural Change in the Beijing Huji Population (2003-2007)

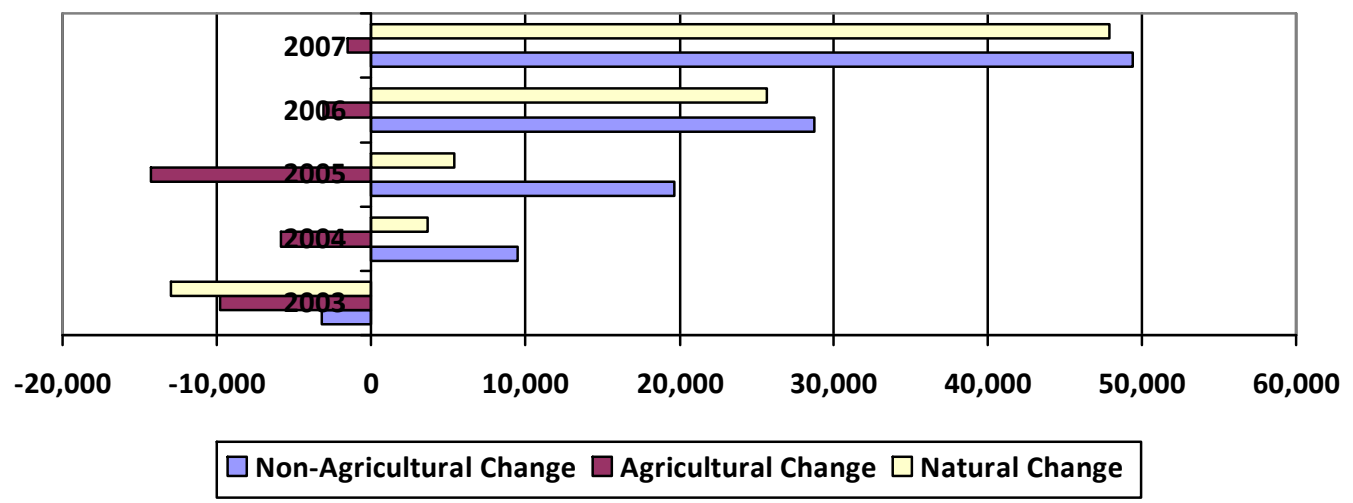

Source: 2004-2008 Beijing Statistical Yearbooks, www.bjstats.gov.cn/

Figure 57: Natural Change Agricultural \& Non-Agricultural Beijing Huji Population (2003-2007)

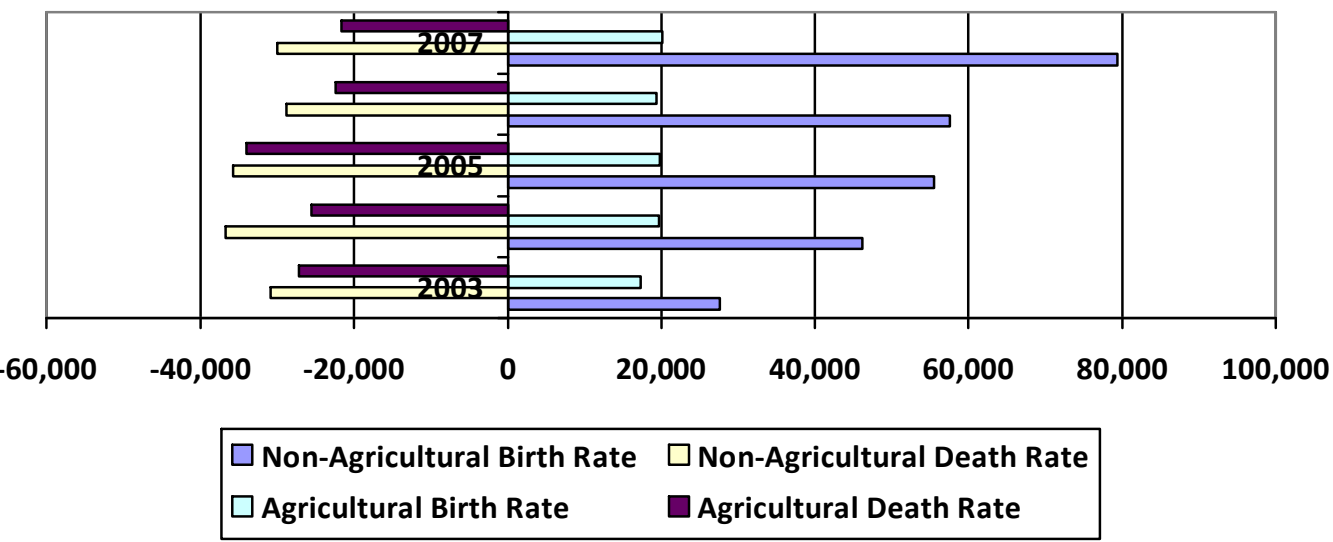

Source: 2004-2008 Beijing Statistical Yearbooks, www.bjstats.gov.cn/

Natural growth of the Beijing huji population shows a rapid lowering of the agricultural population and minor growth in the non-agricultural population. Therefore, the growth of the Beijing huji population over the reform era (from 8.5 million in 1978 to 12.1 million in 2007) is not largely due to natural growth. Rather, non-natural growth of the huji population is the primary driver of Beijing huji population growth. Control of who can transfer their hukou into Beijing city has become an important policy instrument used by local officials to promote population growth deemed in the interests of the city. 


\subsubsection{Beijing Hukou Transfer}

"China has implemented a system of strict control of hukou transfer to balance city development, its bearing capacity and the rate of population growth. In particular, in large cities like Beijing, control of hukou transfer is more pronounced. ${ }^{483}$

Beijing has consistently maintained limited hukou transfer into the city over the period of study. The 1997 MPS Blueprint for Experiments in Small City and Town Huji Management Reform ${ }^{484}$ aimed to encourage urbanisation of nongmin to low density urban areas (small cities and towns) and restrict the mechanical rise in large cities such as Beijing. The 1998 State Council endorsement of the MPS Recommendations Regarding Resolving Several Issues with Current Hukou Management Work strictly defined eligibility for nongzhuanfei and transfer to permanent residence in urban areas and signalled Beijing amongst others for continued strict control of the growth of the huji population. The reforms that have occurred since have prioritised attracting hukou transfers deemed by local government to be in the overall interests of the development of Beijing. Hukou transfer has become an important local government tool for attracting skilled employees, business investors, talented graduates and cultural and sporting stars to the Chinese capital. As the natural rate of growth remains low, inward hukou transfer plays an increasingly important role in determining the makeup of Beijing's huji population.

In later years the majority of growth in Beijing's huji population has been attributable to hukou transfer (see figure 58). Of the non-natural growth the vast majority of it has come from the inward transfer of non-agricultural hukou holders (see figure 59). Whilst both agricultural and non-agricultural inward hukou transfers have remained higher than outward transfers, Beijing's population growth has predominantly come from growth in

\footnotetext{
${ }^{483}$ Xu Xueming 徐学明. 《进京户口完全手册》[Manual to Enter Beijing Hukou]. 北京 [Beijing]: 法律 出版社 [Legal Press], 2005, p.5.

484 《小城镇户籍管理制度改革试点方案》.
} 
the non-agricultural huji population from inward hukou transfer. The actual number of inward non-agricultural hukou transfers has been steady from 2003 to 2007 at an annual average of 180,800 people (see figure 60 ).

Figure 58: Natural and Non-Natural Real Change in the Beijing Huji Population (2003-2007)

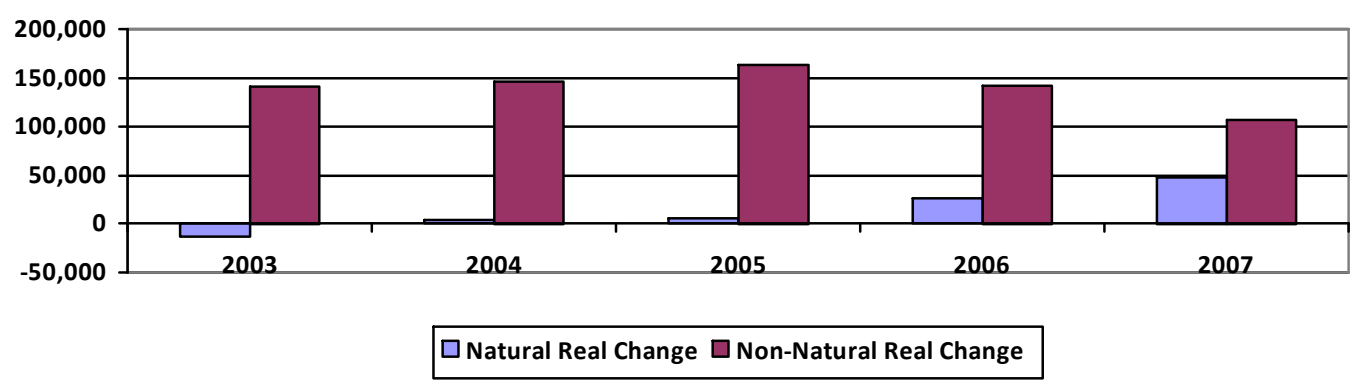

Source: 2004-2008 Beijing Statistical Yearbooks, www.bjstats.gov.cn/

Figure 59: Non-Natural Real Change in the Beijing Huji Population 2003-2007 (Inward - Outward Transfer)

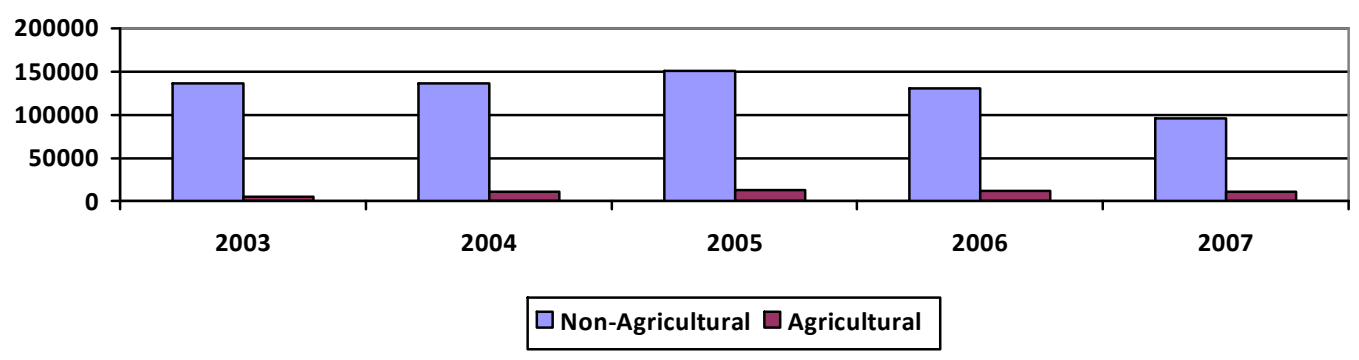

Source: 2004-2008 Beijing Statistical Yearbooks, www.bjstats.gov.cn/

Figure 60: Inward \& Outward Agricultural \& Non-Agricultural Hukou Transfer in Beijing 20032007

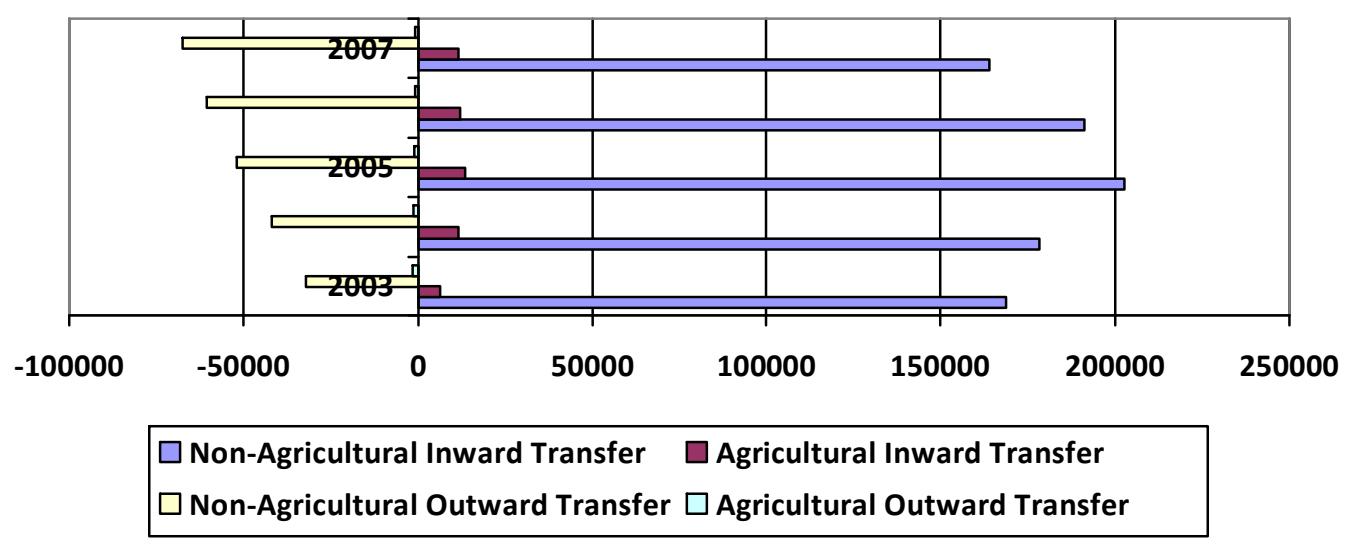

Source: 2004-2008 Beijing Statistical Yearbooks, www.bjstats.gov.cn/

The predominantly non-agricultural inward transfer suggests Beijing municipal authorities are using the huji institution to try to attract the best and brightest urban 
talent from China, Hong Kong, Macao and Taiwan. As a city with extensive political, economic and cultural activity, Beijing is in the enviable position of being able to regulate the makeup of the huji population through hukou transfer. Localisation of hukou transfer decisions has provided local government the power to decide on which applicants receive inward hukou transfer. A variety of municipal bureaus are involved in examining and approving hukou transfer applications. Table 15 lists central and local government departments involved in hukou transfer decisions in Beijing.

Table 15: Government Departments Involved in Beijing Hukou Transfer Decisions

\begin{tabular}{|c|ll|}
\hline \multirow{2}{*}{$\begin{array}{c}\text { Central or Municipal } \\
\text { Government }\end{array}$} & $\begin{array}{l}\text { Beijing Personnel Bureau } \\
\text { 北京市人事局 }\end{array}$ \\
\cline { 2 - 3 } Department & 2. & $\begin{array}{l}\text { Beijing Labour and Social Security Bureau } \\
\text { 北京市劳动和社会保障 }\end{array}$ \\
\cline { 2 - 3 } & 3. $\begin{array}{l}\text { Beijing Public Security Bureau } \\
\text { 北京市公安局 }\end{array}$ \\
\cline { 2 - 3 } & 4. $\begin{array}{l}\text { Ministry of Labour and Social Security } \\
\text { 劳动和社会保障部 }\end{array}$ \\
\cline { 2 - 3 } & 5. $\begin{array}{l}\text { Ministry of Personnel } \\
\text { 人事部 }\end{array}$ \\
\hline
\end{tabular}

Source: Manual to Enter Beijing Hukou (2005), p.7

Throughout the 1990s and early 2000s management of the temporary population and hukou transfer increasingly based its criteria on promoting the managed transfer of people with business enterprises or real estate in Beijing or who were skilled, talented and well educated and the top of their profession. A whole field of scholarship has sprung up surrounding the development of Beijing's labour force with the aim of increasing skills and encouraging the most talented in China to have their career in Beijing. ${ }^{485}$ The new focus on attracting people based on their achievements as opposed to their birth line and location is a significant deviation in huji management made possible through devolution of decision-making to local government. Highly competitive selection criteria act as a development tool for Beijing in the same way skilled and investor migrant categories do in many developed countries keen to attract

${ }^{485}$ See for example: Meng Xiuqin 孟秀勤, and Shi Shaoqin 史绍洁, eds. 《北京人才工作报告》 [Beijing Talent Employment Report]. 北京 [Beijing]: 中国人民大学出版社 [Renmin University of China Publishing], 2007. 
skilled and investor migrants. There are roughly 18 different categories of hukou transfer into Beijing. Each has its own conditions and procedures and differing government oversight and decision-making. Of the 18 categories there are two main types of hukou transfer. The first involves people applying in person to transfer their own hukou into Beijing. The second type of transfer involves Beijing locals applying on behalf of relatives to transfer their hukou into Beijing (see table 16). Xu Xueming argues in the Manual to Enter Beijing Hukou that there are significant differences between these two broad categories. It is likely the transfer of hukou into Beijing is dominated by the relative category as in other cities but statistics are not available.

Table 16: Eighteen Categories of Hukou Transfer into Beijing

\begin{tabular}{|c|c|}
\hline \multirow{11}{*}{$\begin{array}{l}\text { For those applying in } \\
\text { person to transfer hukou } \\
\text { into Beijing }\end{array}$} & 1. Graduates in Beijing work units \\
\hline & $\begin{array}{l}\text { 2. Talented workers in the science and technology industry } \\
\text { 'Beijing City Employment Residence Permit' } 486\end{array}$ \\
\hline & $\begin{array}{l}\text { 3. Talented students returning from abroad and highly talented } \\
\text { people from Hong Kong, Macao and Taiwan }\end{array}$ \\
\hline & 4. Those exhibiting excellence in culture or sport \\
\hline & 5. Talented personnel in the capital's financial sector \\
\hline & 6. Those applying for a 'small city and town hukou' 487 \\
\hline & $\begin{array}{l}\text { 7. Personnel from outside Beijing investing and starting a private } \\
\text { enterprise in Beijing }\end{array}$ \\
\hline & 8. Cadres transferred to central office work units \\
\hline & 9. Graduates employed in central office work units \\
\hline & 10. Retried cadres returning to Beijing \\
\hline & 11. Military cadre transfer \\
\hline \multirow{7}{*}{$\begin{array}{l}\text { For locals applying for } \\
\text { relatives in a foreign } \\
\text { area to transfer hukou } \\
\text { into Beijing }\end{array}$} & 12. Spouse of cadre in a Beijing work unit \\
\hline & 13. Spouse and siblings of personnel of a Beijing work unit \\
\hline & 14. Spouse of cadre in a central office work unit \\
\hline & 15. Spouse of personnel in a central office work unit \\
\hline & 16. Siblings of old cadre in a central office work unit \\
\hline & 17. Dependents of military personnel stationed in Beijing \\
\hline & 18. Husbands and wives, parents, and children of Beijing residents \\
\hline
\end{tabular}

Source: Manual to Enter Beijing Hukou (2005), p.11 \& p.149

486 北京市工作居住证.
487 小城镇户口. 
There are also two main forms of hukou transfer application procedures. The first is done through a Beijing work unit and the basis for hukou transfer into Beijing is for employment in that work unit. The work unit is heavily involved in the application procedure. The second involves applicants applying directly to a local police station to transfer hukou into Beijing. It seems likely applications with the backing of important work units with good local government relations will be more likely to be successful as will those of private enterprises that make significant contributions to the city. The limited rate of inward hukou transfer into Beijing suggests only a small proportion of applicants are successful. Beijing's hukou transfer policies apply to relatives of Beijing residents, personnel in the government or military and China's most talented, well educated, rich and successful citizens. The majority of Beijing's 'temporary' migrants are excluded from hukou transfer as they do not fall into any of these categories. The first seven categories of hukou transfer represent Beijing's move in recent years to attract China's best and brightest. Hukou transfer was once exclusively for cadres, relatives of locals and a small number of education and skilled personnel transfers. There are now seven distinct categories of hukou transfer into Beijing based on what the applicant can offer the city.

The first category is for graduates employed in Beijing work units. For many Beijing students from other provinces the final year of study at a Beijing university is taken up with applications and internships to try to get a foot in the door of a Beijing work unit. Some students have even commented that hukou is more important than the type of employment when it comes to prospective jobs and that Beijing hukou is one of the best hukou in China. The opportunity to transfer hukou into Beijing through this category is limited to top university graduates with skilled employment in a Beijing work unit. Having education and skills wanted by Beijing work units is critical as the work unit is 
required to support the application. The second category of hukou transfer is for skilled personnel employed in state and private sector science and technology open zones in Beijing. Applicants need to have at least an undergraduate degree and must be highly skilled in their area or have a $\mathrm{PhD}$ from overseas. People meeting these conditions can apply for a 'Beijing City Employment Residence Permit'. The third category is for talented students returning from abroad and highly talented people from Hong Kong, Macao and Taiwan. The minimum requirement is an undergraduate degree. Those from Hong Kong, Macao and Taiwan are also preferred to have experience in an industry. Spouse and siblings of both returning students and those from Hong Kong, Macao and Taiwan can also transfer their hukou into Beijing.

The fourth category is for those exhibiting excellence in culture or sport. This category applies to famous national and international artists and sportspeople awarded a high international award or who are first class within China. It is also for young artists and sportspeople with talent. The fifth category is for talented personnel in the capital's financial sector. Applicants need at least a master degree, to be under 45 and have extensive experience. Successful applicants can also transfer their spouse and sibling's hukou into Beijing. The sixth category is for people applying for a 'small city and town hukou'. Beijing has 14 satellite cities and central towns designated as small cities and towns. These small cities and towns transfer agricultural hukou holders to urban permanent hukou within the socio-economic planning guidelines. Agricultural hukou holders with fixed residence and stable employment or source of income from these areas can apply for hukou transfer. There are also experiments granting people with hukou from other provinces of China the opportunity to transfer into Beijing. These applicants must have invested around 500,000 USD in the small city or town. 
The seventh category is for personnel from outside Beijing investing or starting a private enterprise in Beijing. These applicants must own a house in the hukou zone, have a clean criminal record, and most importantly own an enterprise that has been running for more than three years. In Dongcheng, Xicheng, Chongwen, Xuanwu, Chaoyang, Haidian, Fengtai and Shijingshan the enterprise must pay annual tax of 800,000 Yuan (or have paid 3 million over the last three years) and employ more than 100 people. ${ }^{488}$ Conditions are roughly half for areas of Beijing outside of these areas. These categories set a high bar for hukou transfer into Beijing. Table 17 lists these seven 'meritocratic' hukou transfer categories and the legal regulations underpinning them.

Table 17: Meritocratic Hukou Transfer Categories and Related Regulations in Beijing

\begin{tabular}{|c|c|}
\hline $\begin{array}{c}\text { Hukou Transfer } \\
\text { Category }\end{array}$ & Related Regulations \\
\hline $\begin{array}{c}\text { Graduates in Beijing } \\
\text { work units }\end{array}$ & $\begin{array}{l}\text { - Beijing City } 2005 \text { Procedures for Attracting Graduates not Born in Beijing } \\
2005 \text { 年北京市引进非北京生源毕业生工作程序 } \\
\text { - Notification Regarding Issues Relating to Accepting Vocational School } \\
\text { Graduates not Born in Beijing City in } 2004 \text { 关于北京市 } 2004 \text { 年接受非北 } \\
\text { 京生源高校毕业生有关问题的通知 } \\
\text { Notification Regarding Issues Relating to Accepting } 2002 \text { Vocational } \\
\text { School Graduates not Born in Beijing City (2001)关于北京市 } 2002 \text { 年接受 } \\
\text { 普通高等学校非北京生源应届毕业生有关问题的通知[2001] } \\
\text { Notification of Problems Relating to Beijing City Personnel Bureau } \\
\text { Accepting Family Hardships of Graduates not Born in Beijing City 北京市 } \\
\text { 人事局接受家庭有实际困难非北京生源毕业生有关问题的通知[2000] } \\
\text { Procedures for Zhongguan Village Science and Technology Zone to Accept } \\
\text { Vocational Graduates not Born in Beijing City 中关村科技园区接受非北 } \\
\text { 京市生源高校毕业生办法 }\end{array}$ \\
\hline $\begin{array}{l}\text { Talented workers in } \\
\text { the science and } \\
\text { technology industry } \\
\text { 'Beijing City } \\
\text { Employment } \\
\text { Residence Permit' }\end{array}$ & $\begin{array}{l}\text { - Interim Provisions of Beijing City for Attracting Talent and Processing } \\
\text { 'Beijing City Employment Residence Permit' (1999) 北京市引进人才和办 } \\
\text { 理 (北京市工作居住证) 的暂行办法 [1999] } \\
\text { Notification Regarding Recommendations for Implementing the Beijing } \\
\text { City Employment Residence Permit System (2003) 关于实施北京市工作居 } \\
\text { 住证制度若干意见的通知[2003] }\end{array}$ \\
\hline $\begin{array}{l}\text { Talented students } \\
\text { returning from abroad } \\
\text { and highly talented } \\
\text { people from Hong } \\
\text { Kong, Macao and } \\
\text { Taiwan }\end{array}$ & $\begin{array}{l}\text { - Regulations for Beijing City Encouraging Students Returning from Abroad } \\
\text { to Carve out a Career in Beijing (2000) 北京市鼓励留学人员来京创业工 } \\
\text { 作的若干规定[2000] } \\
\text { Implementation Procedures for Regulations for Beijing City Encouraging } \\
\text { Students Returning from Abroad to Carve out a Career in Beijing (2001) } \\
\text { 北京市鼓励留学人员来京创业工作的若干规定实施办法 [2001] } \\
\text { Implementation Recommendations for Policy Relating to Highly Talented } \\
\text { Personnel from Hong Kong, Macao and Taiwan (2002) 香港、澳门和台 } \\
\text { 湾地区高级人才来京工作有关政策的实施意见 [2002] }\end{array}$ \\
\hline
\end{tabular}

488 东城、西城、崇文、宣武、朝阳、海淀、丰台和石景山. 


\begin{tabular}{|c|c|}
\hline $\begin{array}{l}\text { Those exhibiting } \\
\text { excellence in culture or } \\
\text { sport }\end{array}$ & $\begin{array}{l}\text { - Notification of Interim Provisions Regarding Regulations of Beijing City } \\
\text { Encouraging and Attracting Talented People Exhibiting Excellence in } \\
\text { Culture or Sports Carving out their Career in Beijing (2004) 北京市关于 } \\
\text { 鼓励和吸引优秀文化体育人才来京创业工作若干暂行规定的通知 } \\
\text { [2004] } \\
\text { - Implementation Procedures for Interim Provisions Regarding Regulations } \\
\text { of Beijing City Encouraging and Attracting Talented People Exhibiting } \\
\text { Excellence in Culture or Sports Carving out their Career in Beijing (2004) } \\
\text { 北京市关于鼓励和吸引优秀文化体育人才来京创业工作若干暂行规定 } \\
\text { 实施办法 [2004] } \\
\text { Committee and Organisation Regulations for Beijing City Sporting and } \\
\text { Cultural Talent Qualifications 北京市优秀文化体育人才资格认定委员会 } \\
\text { 组织工作章程 }\end{array}$ \\
\hline $\begin{array}{l}\text { Talented personnel in } \\
\text { the capital's financial } \\
\text { sector }\end{array}$ & $\begin{array}{l}\text { - Notification Regarding Recommendations on Accelerating the } \\
\text { Development of the Capital's Financial Sector (2005) 关于印发促进首都 } \\
\text { 金融产业发展的意见的通知[2005] }\end{array}$ \\
\hline $\begin{array}{l}\text { Those applying for a } \\
\text { 'small city and town } \\
\text { hukou' }\end{array}$ & $\begin{array}{l}\text { - Experimental Procedures for Beijing City Suburban Small City and Towns } \\
\text { Establishing Experimental Urban Huji Management (1997) 北京市郊区小 } \\
\text { 城镇建设试点城镇户籍管理试行办法[1997] } \\
\text { Implementation Detals for the Experimental Procedures for Beijing City } \\
\text { Suburban Small City and Towns Establishing Experimental Urban Huji } \\
\text { Management (1997) 关于转发北京市郊区小城镇建设试点城镇户籍管理 } \\
\text { 试行办法实施细则 [1997] } \\
\text { Notification Regarding the Beijing Municipal Government Endorsement of } \\
\text { the City Public Security Bureau Recommendations Regarding Accelerating } \\
\text { Reform of the Small City and Town Huji Management System (2002) 北京 } \\
\text { 市人民政府批转市公安局关于推进小城镇户籍管理制度改革意见的通 } \\
\text { 知[2002] }\end{array}$ \\
\hline $\begin{array}{l}\text { Personnel from outside } \\
\text { Beijing investing and } \\
\text { starting a private } \\
\text { enterprise in Beijing } \\
\end{array}$ & $\begin{array}{l}\text { - Implementation Procedures Regarding Non-local Investors and Business } \\
\text { Owners Applying for Permanent Beijing Hukou (2001) 关于外地来京投资 } \\
\text { 开办私营企业人员办理北京市常住户口试行办法[2001] }\end{array}$ \\
\hline
\end{tabular}

Source: Manual to Enter Beijing Hukou (2005), various chapters

By strictly controlling hukou transfer through huji management, local governments can influence the socio-economic development of the city by selecting those deemed the most able to contribute through their technical or scientific expertise, their financial ability, their ability to invest or start an enterprise in Beijing or their ability to promote a cultural or sporting field through their own achievements. Because Beijing has a very high standard of living and is the centre of most national enterprises and government organs, the pull of the city allows local authorities to set the conditions for hukou transfer a lot higher than other areas. This highly competitive system of huji transfer management increases Beijing's ability to remain a leading city in China. 
The huji institution has successfully been modified by local government to promote local development. Liberalisation of hukou transfer is evidenced by these predominantly post-2000 regulations. The introduction of these formal rules governing hukou transfer based not on relative or cadre connections but rather on the merits of the candidate is a significant deviation from pre-1978 hukou transfer regulations. However, as the conditions on inward hukou transfer remain high, the majority of the migrants who have entered Beijing over the reform era have instead been accorded temporary residency status. These non-huji residents have increased in size over the reform era and make up an important part of the Beijing economy. The introduction of temporary permits has reformed the huji institution to allow temporary migration for the purpose of economic development. However, many of these migrant labourers/contract workers remain in Beijing long-term. This shows a gap between temporary status laid out in the formal huji regulations and the practice of non-huji migrants in Beijing.

\subsubsection{Beijing Non-Huji Residents}

"Most nongmingong enter the city for employment and accelerate socio-economic development in Beijing. But at the same time, [they] also bring a lot of new problems. Beijing City is confronted with the challenge of finding ways to strengthen the management and provision of services to nongmingong., 489

As in other parts of China, Beijing's floating population/non-huji population has increased significantly over the reform era. During the first, second and third decade of the period of study, the non-huji population averaged $60 \%$ annual growth, growing from 218,000 in 1978 to $4,197,000$ in 2007 . As with the trend identified at the national level, the growth of the temporary population began before the formal introduction of temporary residency permits. In Beijing the non-huji population was at least 230,000 by

\footnotetext{
${ }^{489}$ Beijing City Research Group 北京市调研组. "北京市农民工管理和服务问题研究" [Research into Beijing City Nongmingong Management and Service Issues]. In《中国农民工调研报告/国务院研究室 课题组》[China's Nongmingong Research Report/Discussion Group of the Research Department of the State Council], edited by Wei Liqun 魏礼群 and Han Changfu 韩长赋. 北京[Beijing]: 中国言实出版社 [China Yanshi Publishing], 2006.
} 
1985 when the Beijing Municipal Government issued two regulations governing hukou management of the temporary population. ${ }^{490}$ These regulations followed the national directive that same year allowing non-local residents to apply for temporary permits that gave them the right to reside temporarily in Beijing and to work and rent accommodation. They also stipulated the floating population must register at the local police station and promoted strict enforcement of temporary permits to strengthen governance of the floating population. In 1989 another two directives appeared aiming to further strengthen governance of the floating population, ${ }^{491}$ and in 1994 Provisional Regulations Regarding Employment of Rural Inter-Provincial Migrants was issued. ${ }^{492}$ This last regulation sought to 'guide the inter-provincial migrant labour force in an orderly flow' and to standardise procedures for local enterprises hiring migrant workers from other provinces.

In 1995 the Beijing City Municipal Government issued a further directive aimed to strengthen huji management of the temporary population in Beijing. This regulation focused on strengthening the procedures governing the issuing of 'Temporary Residence Permits'《暂住证》. Article 6 directed local government in Beijing to introduce measures to control the growth of the temporary population and to ensure growth does not go over a certain proportion of the local urban population.

\footnotetext{
${ }^{490}$ Beijing Municipal Government Regulations Regarding Hukou Management of the Temporary Population (1985 no longer in force) 北京市人民政府关于暂住人口户口管理的规定<已经失效> ; Detailed Regulations [Regarding] Implementing 'Beijing Municipal Government Regulations Regarding Hukou Management of the Temporary Population' (1985 no longer in force) 实施《北京市人民政府关 于暂住人口户口管理的规定》的细则 $<$ 已经失效 $>$.

${ }^{491}$ Notification Regarding Strengthening Personnel File Management of the Floating Population (1989) 《关于加强流动人员人事档案管理工作的通知》; Interim Provisions for the Personnel File Management of Labourers in Beijing's Floating Population (1989) 《北京市流动中的工人人事档案管 理暂行规定》.

492 Provisional Regulations Regarding Employment of Rural Inter-Provincial Migrants 《农村劳动力跨 省流动就业管理暂行规定》.
} 
"All levels of the Public Security Bureau should accelerate control over the scale of foreign personnel entering Beijing through huji management." 493

The Beijing 'Foreign Personnel Employment Permit'《外来人员就业证》was introduced in 1995 to 'strengthen management of foreign labourers employed in Beijing'. ${ }^{494}$ This permit required all migrant labourers employed in Beijing to register for an employment permit. To apply for an employment permit an applicant needed to provide the following 6 items: a letter from their employer; their identification card; their 'Temporary Residence Permit'《暂住证》 issued when declaring temporary residence at the local police station; their 'Outward Personnel Employment Registration Card'《外出人员就业登记卡》 issued by the labour bureau and municipal government in the applicants permanent huji location; a 'Marriage and Education Certificate' 《婚育 证》 issued by family planning authorities in their area of temporary residence; and any other documents required by law or regulation. The introduction of the requirement for an 'Outward Personnel Employment Registration Card', especially strict for interprovincial migrants, significantly increased the unification of the national huji institution allowing Beijing authorities to exchange information and records with authorities in migrant sending areas. This had become increasingly necessary as the nongmingong population became more multi-provincial. Beijing's nongmingong population originate from all 30 provinces but $64 \%$ originate from the five large sending provinces of Hebei, Henan, Anhui, Shandong, and Sichuan. ${ }^{495}$

Statistics from the Beijing City Statistical Bureau show the temporary population in Beijing to have grown to 4,197,000 people in 2007. As figure 61 shows, the Beijing

\footnotetext{
${ }^{493}$ Beijing City Regulations for Huji Management of Personnel in Beijing from Foreign Areas (1995) 《北京市外地来京人员户籍管理规定》。

${ }^{494}$ Procedures for Managing the 'Beijing City Foreign Personnel Employment Permit' (1995) 《〈北京 市外来人员就业证〉管理办法》。

${ }^{495}$ Beijing City Research Group 北京市调研组. "北京市农民工管理和服务问题研究" [Research into Beijing City Nongmingong Management and Service Issues].
} 
non-huji population has grown considerably since 1978 when it only accounted for $2.5 \%$ of the total population. By 1987 this had risen to $5.6 \%$. By 1997 it was $12.5 \%$ and by 2007 it had more than doubled to $25.7 \%$. Whilst the non-huji population remains only $25 \%$ of the total Beijing population, it has accounted for $52 \%$ of the total growth over the reform era. Since 1994 non-huji growth has accounted for 70\% of Beijing's total population growth. From 1978 to 2007 the Beijing huji population grew by 3.6 million people. The non-huji population grew by almost 4 million. This is remarkable considering the huji population was 8.5 million in 1978 whilst the non-huji population was just over 200,000. Figure 62 shows the non-huji Beijing population over the reform era.

Figure 61: Beijing Huji and Non-Huji Population 1978-2007 (millions)

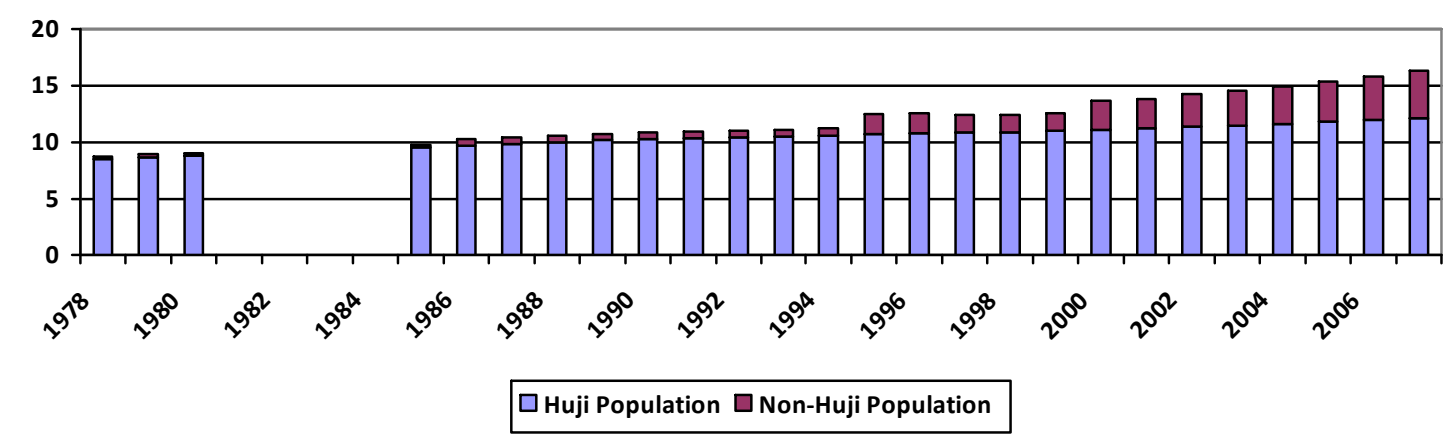

Source: 2008 Beijing Statistical Yearbook, www.bjstats.gov.cn/

Figure 62: Beijing Non-Huji Population 1978-2007

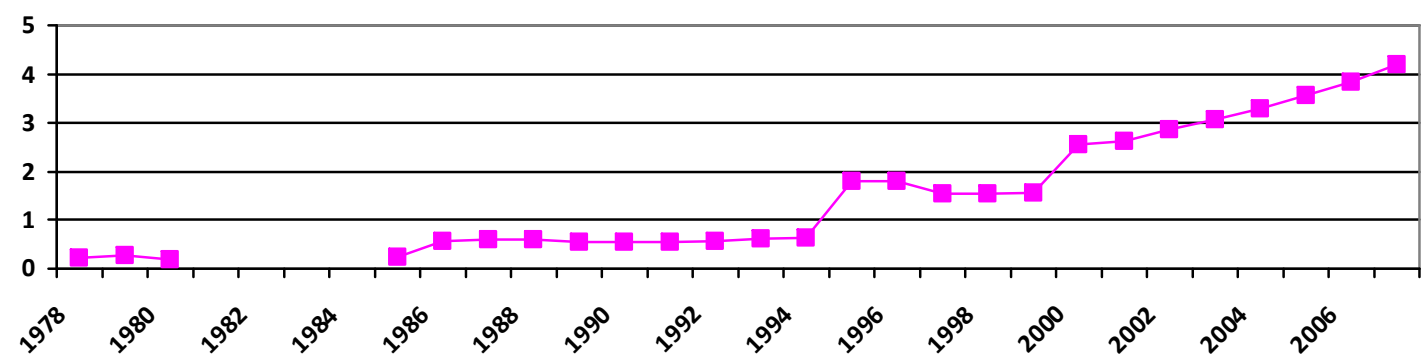

Source: 2008 Beijing Statistical Yearbook, www.bjstats.gov.cn/

Since the mid-1990s the majority of growth in Beijing's population has come not from growth in the huji population but from growth in the non-huji population. The 
accumulative nature of the growth shows inward migration is far greater than outward migration. There is an important gap between the formal regulations of the huji institution and the increasing permanency of the 'temporary' population. Beijing's nonhuji population have interpreted government sanctioned temporary permits as an opportunity to reside for long periods, if not permanently, in Beijing. Statistics from the Beijing Statistical Bureau show that by 2007 one in every four Beijing residents were a non-huji resident. Of the non-huji residents surveyed by the Beijing Social Sciences Planning Office in 2007, the average time spent at destination was 5 years and 10 months (see figure 63). This suggests a lot of what is institutionally defined as 'temporary' residency, is in reality increasingly permanent in nature.

\section{Figure 63: Average Time at Destination of Beijing Non-Huji Residents}

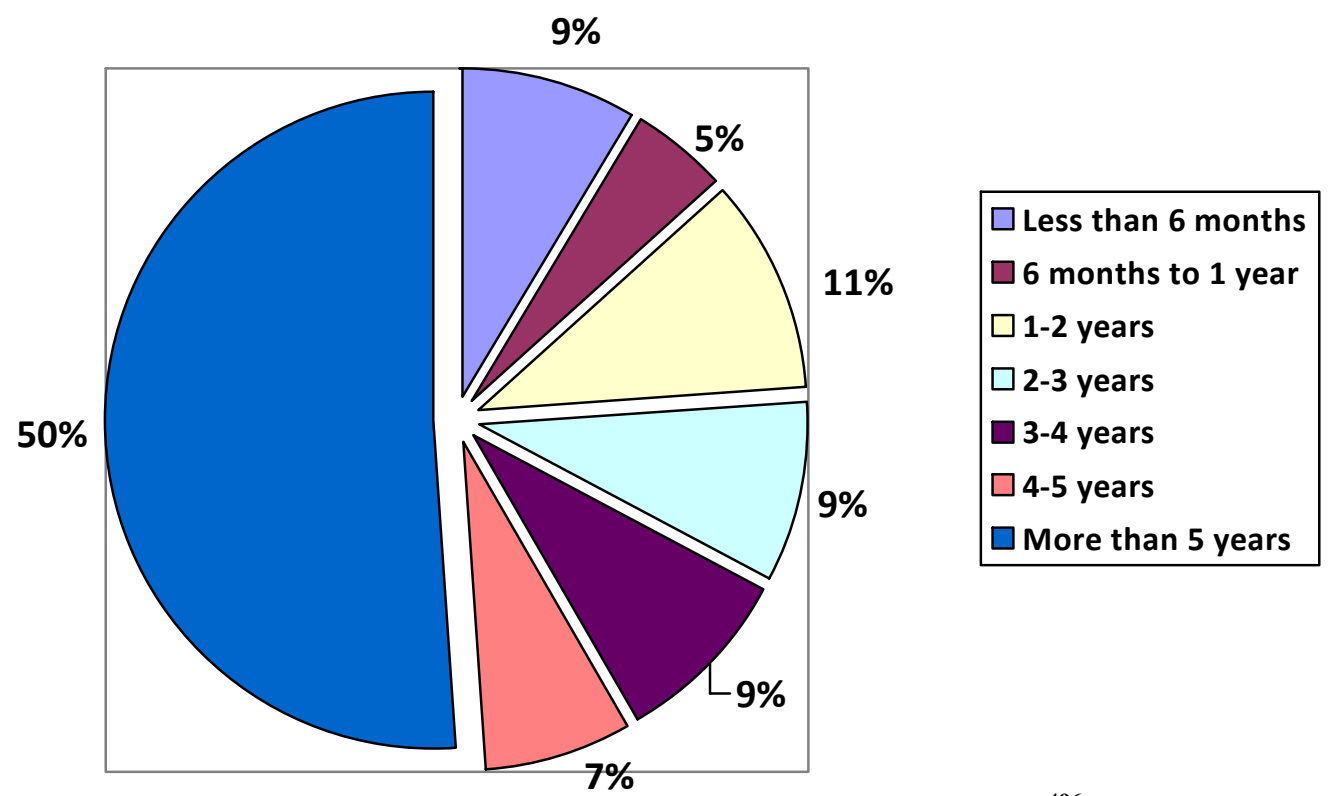

Source: Research Report on the Growth of the Beijing Population, p. $37^{496}$

The majority of Beijing's non-huji population is of agricultural status. By $2006,82 \%$ of the non-huji population in Beijing held agricultural hukou (see table 18). Whilst the most significant form of growth in the huji population was from inward transfer of non-

\footnotetext{
${ }^{496}$ Beijing City Philosophy and Social Sciences Planning Office 北京市哲学社会科学规划办公室. 《北 京人口发展研究报告》[Research Report on the Growth of the Beijing Population]. 北京[Beijing]: 同心 出版社[Tongxin Publishers], 2007.
} 
agricultural hukou holders. The growth of the non-huji population in Beijing has been dominated by agricultural hukou holders or nongmingong.

Table 18: Hukou Type of the Non-Huji Beijing Population (2005 \& 2006)

\begin{tabular}{|c|c|c|}
\hline Hukou Type & 2005 Survey & 2006 Survey \\
\hline Agricultural & 71.5 & 82.2 \\
\hline Non-Agricultural & 28.5 & 17.8 \\
\hline
\end{tabular}

Source: Research Report on the Growth of the Beijing Population, p.7

In some areas of Beijing the floating population is more than the local population. In Chaoyang District some 'rural communities' have a local huji population of 22,000 and a floating population of 50,000 (more than double). In a few 'rural communities' the floating population is five times the huji population. Management of the huji system is underfunded in the face of the socio-economic problems nongmingong have brought to these areas. ${ }^{497}$ At destination, non-agricultural non-huji residents are more likely to reside in urban communities. Agricultural hukou non-huji residents are just as likely to reside in rural communities as urban communities (see table 19).

Table 19: Community Type at Destination of the Floating Population in Beijing

\begin{tabular}{|c|c|c|}
\hline & Community Type & Percentage \\
\hline \multirow{2}{*}{$\begin{array}{c}\text { Agricultural Hukou Floating } \\
\text { Population Household } \\
(80 \%)\end{array}$} & $\begin{array}{c}\text { Urban Community } \\
\text { 城市社区 }\end{array}$ & 46.6 \\
\cline { 2 - 3 } & $\begin{array}{c}\text { Rural Community } \\
\text { 农村社区 }\end{array}$ & 53.4 \\
\hline $\begin{array}{c}\text { Non-Agricultural Hukou Floating } \\
\text { Population Household } \\
(20 \%)\end{array}$ & $\begin{array}{c}\text { Urban Community } \\
\text { 城市社区 }\end{array}$ & 75.0 \\
\cline { 2 - 3 } & $\begin{array}{c}\text { Rural Community } \\
\text { 农村社区 }\end{array}$ & 25.0 \\
\hline
\end{tabular}

Source: Research Report on the Growth of the Beijing Population, p.92

Beijing has grown considerably from the influx of 4 million non-huji residents. In 2007, the proportion of non-huji residents to huji residents was highest in urban functional districts (30\%) and new urban development districts (27\%). These districts surround the

${ }^{497}$ Beijing City Research Group 北京市调研组. "北京市农民工管理和服务问题研究" [Research into Beijing City Nongmingong Management and Service Issues], p.365. 
capital functional districts at the centre of Beijing which have a lower proportion of non-huji residents $(18 \%$, see table 20$)$.

Table 20: Huji and Non-Huji Population by Beijing District 2005 - 2007 (thousands)

\begin{tabular}{|c|c|c|c|c|c|c|c|c|}
\hline Year & \multicolumn{4}{|c|}{2005} & \multicolumn{4}{|c|}{2007} \\
\hline District & Total & Non-Huji & Huji & $\begin{array}{l}\text { Non-Huji } \\
(\%)\end{array}$ & Total & Non-Huji & Huji & $\begin{array}{c}\text { Non-Huji } \\
(\%)\end{array}$ \\
\hline $\begin{array}{l}\text { Dongcheng } \\
\text { 东城 区 }\end{array}$ & 549 & 102 & 447 & 18.6 & 552 & 101 & 451 & 18.3 \\
\hline $\begin{array}{l}\text { Xicheng } \\
\text { 西城区 }\end{array}$ & 660 & 118 & 542 & 17.9 & 665 & 110 & 555 & 16.5 \\
\hline $\begin{array}{l}\text { Chongwen } \\
\text { 崇文区 }\end{array}$ & 311 & 51 & 260 & 16.4 & 299 & 55 & 244 & 18.4 \\
\hline $\begin{array}{l}\text { Xuanwu } \\
\text { 宣武区 }\end{array}$ & 532 & 93 & 439 & 17.5 & 553 & 109 & 444 & 19.7 \\
\hline $\begin{array}{c}\text { Capital Functional } \\
\text { Districts } \\
\text { 首都功能核心区 }\end{array}$ & 2052 & 364 & 1688 & 17.7 & 2069 & 375 & 1694 & 18.1 \\
\hline $\begin{array}{c}\text { Chaoyang } \\
\text { 朝阳区 }\end{array}$ & 2802 & 840 & 1962 & 30.0 & 3001 & 963 & 2038 & 32.1 \\
\hline $\begin{array}{l}\text { Fengtai } \\
\text { 丰台区 }\end{array}$ & 1568 & 366 & 1202 & 23.3 & 1693 & 447 & 1246 & 26.4 \\
\hline $\begin{array}{l}\text { Shijingshan } \\
\text { 石景山区 }\end{array}$ & 524 & 149 & 375 & 28.4 & 546 & 167 & 379 & 30.6 \\
\hline $\begin{array}{c}\text { Haidian } \\
\text { 海 淀 区 }\end{array}$ & 2586 & 737 & 1849 & 28.5 & 2814 & 848 & 1966 & 30.1 \\
\hline $\begin{array}{c}\text { Urban Functional } \\
\text { Districts } \\
\text { 城市功能拓展区 }\end{array}$ & 7480 & 2092 & 5388 & 28.0 & 8054 & 2425 & 5629 & 30.1 \\
\hline $\begin{array}{c}\text { Fangshan } \\
\text { 房山区 }\end{array}$ & 870 & 119 & 751 & 13.7 & 887 & 130 & 757 & 14.7 \\
\hline $\begin{array}{l}\text { Tongzhou } \\
\text { 通州区 }\end{array}$ & 867 & 197 & 670 & 22.7 & 965 & 278 & 687 & 28.8 \\
\hline $\begin{array}{l}\text { Shunyi } \\
\text { 顺义区 }\end{array}$ & 711 & 156 & 555 & 21.9 & 736 & 173 & 563 & 23.5 \\
\hline $\begin{array}{l}\text { Changping } \\
\text { 昌平区 }\end{array}$ & 782 & 219 & 563 & 28.0 & 896 & 305 & 591 & 34.0 \\
\hline $\begin{array}{l}\text { Daxing } \\
\text { 大兴区 }\end{array}$ & 886 & 253 & 633 & 28.6 & 978 & 337 & 641 & 34.5 \\
\hline $\begin{array}{c}\text { New Urban } \\
\text { Development } \\
\text { Districts } \\
\text { 城市发展新区 }\end{array}$ & 4116 & 944 & 3172 & 22.9 & 4462 & 1223 & 3239 & 27.4 \\
\hline $\begin{array}{l}\text { Mentougou } \\
\text { 门头沟区 }\end{array}$ & 277 & 41 & 236 & 14.8 & 270 & 32 & 238 & 11.9 \\
\hline $\begin{array}{l}\text { Huairou } \\
\text { 怀柔区 }\end{array}$ & 322 & 53 & 269 & 16.5 & 316 & 45 & 271 & 14.2 \\
\hline $\begin{array}{l}\text { Pinggu } \\
\text { 平谷区 }\end{array}$ & 414 & 24 & 390 & 5.8 & 424 & 32 & 392 & 7.5 \\
\hline $\begin{array}{l}\text { Miyun } \\
\text { 密云县 }\end{array}$ & 439 & 35 & 404 & 8.0 & 449 & 40 & 409 & 8.9 \\
\hline $\begin{array}{l}\text { Yanqing } \\
\text { 延庆县 }\end{array}$ & 280 & 20 & 260 & 7.1 & 286 & 25 & 261 & 8.7 \\
\hline $\begin{array}{c}\text { Ecological } \\
\text { Development } \\
\text { Districts } \\
\text { 生态涵养发展区 }\end{array}$ & 1732 & 173 & 1559 & 10.0 & 1745 & 174 & 1571 & 10.0 \\
\hline $\begin{array}{l}\text { City Total } \\
\text { 全市 }\end{array}$ & 15380 & 3573 & 11807 & 23.2 & 16330 & 4197 & 12133 & 25.7 \\
\hline
\end{tabular}

Source: 2008 Beijing Statistical Yearbook, www.bjstats.gov.cn/ 
The non-huji population in Beijing are predominantly engaged in low-end employment earning significantly less than the huji population. A 2005 survey of secondary and tertiary employee incomes found that on average the huji population earned 1831 Yuan per month whereas the non-huji population earned on average 1412 Yuan per month. $80 \%$ of the non-huji population are nongmingong with agricultural hukou status. They earned an average of 1059 Yuan per month. ${ }^{498}$ This wage is however still 4 times the national average for nongmin. The non-huji population are predominantly involved in service industries and production and transport (75\%). The huji population are distributed more evenly across the various types of employment in Beijing (see figure 64). The State Council Research Report on Nongmingong in Beijing states $84 \%$ of nongmingong in Beijing are employed in construction, restaurants and hotels, wholesale and retail, manufacturing, public services and other social service industries. ${ }^{499}$

Figure 64: Comparison of Non-local \& Huji Employment Type in Beijing (\%, 2000, 2005)

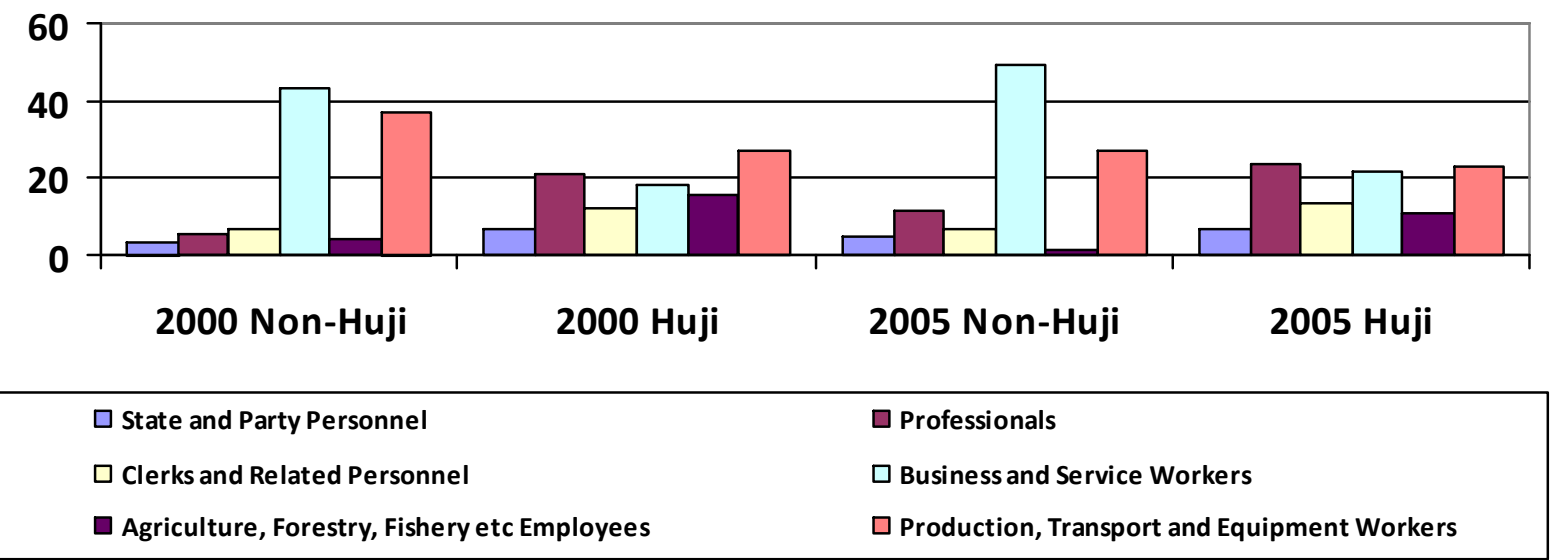

Source: Research Report on the Growth of the Beijing Population, p.21

The distribution of the huji and non-huji population differs considerably across various employment categories. Huji residents are more likely to be professionals or work for the state. Non-huji residents are more likely to be service workers (see table 21).

\footnotetext{
${ }^{498}$ Beijing City Philosophy and Social Sciences Planning Office 北京市哲学社会科学规划办公室. 《北 京人口发展研究报告》[Research Report on the Growth of the Beijing Population] p.23.

${ }^{499}$ Beijing City Research Group 北京市调研组. "北京市农民工管理和服务问题研究" [Research into Beijing City Nongmingong Management and Service Issues].
} 
Table 21: Comparison of Huji and Non-Huji Population Employment in Beijing

\begin{tabular}{|c|c|c|c|c|}
\hline \multirow[b]{2}{*}{ Employment } & \multicolumn{2}{|c|}{2000} & \multicolumn{2}{|c|}{2005} \\
\hline & $\begin{array}{l}\text { Non- } \\
\text { Huji }\end{array}$ & Huji & $\begin{array}{l}\text { Non- } \\
\text { Huji }\end{array}$ & Huji \\
\hline State and Party Personnel & 3.24 & 6.63 & 4.83 & 6.68 \\
\hline Professionals & 5.58 & 20.82 & 11.27 & 23.51 \\
\hline Clerks and Related Personnel & 6.67 & 11.84 & 6.45 & 13.75 \\
\hline Business and Service Workers & 43.20 & 18.45 & 49.21 & 21.71 \\
\hline Including: Sales & 24.40 & 9.21 & 25.94 & 9.83 \\
\hline Store Personnel & 0.79 & 1.68 & 0.81 & 1.19 \\
\hline Restaurant Staff & 9.53 & 2.24 & 9.60 & 2.21 \\
\hline Hotel and Leisure Resort Staff & 1.89 & 1.20 & 1.93 & 1.34 \\
\hline Transport Service Workers & 0.25 & 1.01 & 0.54 & 1.99 \\
\hline Medical and Health Assistants & 0.01 & 0.07 & 0.10 & 0.13 \\
\hline Public Service Staff & 6.30 & 3.00 & 9.33 & 4.37 \\
\hline $\begin{array}{l}\text { Agriculture, Forestry, Herding, Fishery and Aquaculture } \\
\text { Employees }\end{array}$ & 4.32 & 15.47 & 1.40 & 11.00 \\
\hline Production, Transport and Equipment Workers & 37.0 & 26.78 & 26.69 & 23.13 \\
\hline Other & 0.00 & 0.01 & 0.16 & 0.23 \\
\hline
\end{tabular}

Source: Research Report on the Growth of the Beijing Population, p.21

The socio-economic position of the non-huji population remains on average well below the huji population. Figure 65 compares huji status by the number of consumable items per 100 households. Beijing huji residents consume far more than non-huji residents. Non-agricultural non-huji residents consume slightly more than agricultural non-huji residents. This shows the division between huji and non-huji residency status remains a significant marker of socio-economic status. Because the non-huji population are recently arrived residents in Beijing that lack huji status they are for most relegated to the low end of the Beijing economy.

Figure 65: Consumable Items per 100 Households by Hukou Status in Beijing

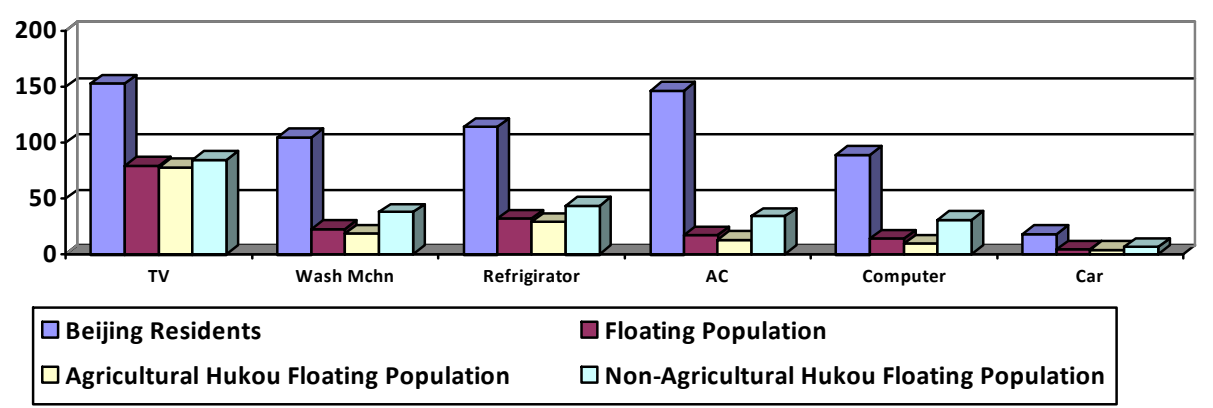

Source: Research Report on the Growth of the Beijing Population, p.92 
Beijing has urbanised considerably since 1978. Many of the 'rural communities' nonhuji migrants settle in are highly urbanised. In the 1970s when the first Victoria University students exchanged to Beijing universities, some were 'sent down' to rural areas that by 2007 when this fieldwork was conducted were already urban centres. Beijing's level of urbanisation has grown consistently over the period of study rising from $55 \%$ in 1978 to $85 \%$ in 2007 . Beijing was around $25 \%$ more urbanised in 1978 and $40 \%$ more urbanised in 2007 than the national average which remains below $50 \%$. Many of the once rural regions of Beijing have been swept up in the spread of urban living. Urbanisation has led to a decrease in the proportion of the number of the population classified as rural (see figure 66).

Figure 66: Beijing Rural Urban Populations 1978-2007 (millions)

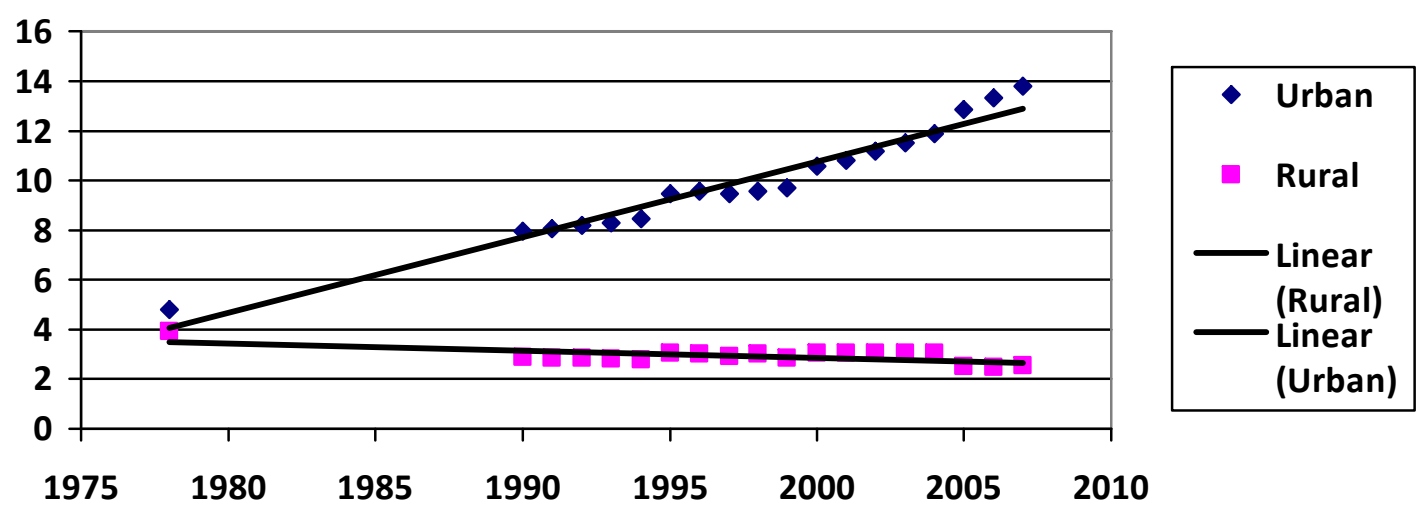

Source: 2008 Beijing Statistical Yearbook, www.bjstats.gov.cn/

A decreasing number of the total population being classified as rural also corresponds to an increase in the number of employees in the urban workforce. Rural employee numbers by comparison have remained steadily below 2 million over the entire period of study (see figure 67). As growth in the number of urban employees has not been matched by growth in the number of rural employees the proportion of the total workforce in urban areas has grown from 65\% in 1978 to nearly $80 \%$ in 2007. 
Figure 67: Rural and Urban Workforce in Beijing (millions)

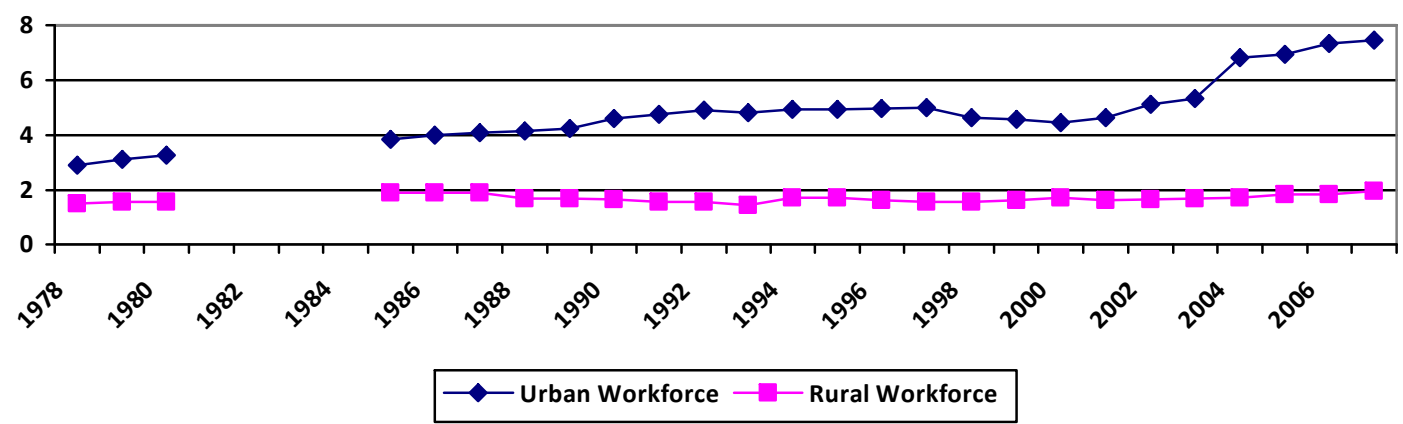

Source: 2008 Beijing Statistical Yearbook, www.bjstats.gov.cn/

Employment in urban areas has also changed considerably over the period of study. Whereas in 1978 the vast majority of Beijing workers were employed in state owned enterprises, from the mid-1990s an increasing number of the urban workforce were employed in work units of non-state ownership. Of the total 4.8 million people employed in Beijing's urban areas in 2007, 2.9 million or $60 \%$ were employed in private enterprises (see figure 68). The marketization of Beijing's employment market has corresponded with the growth of the non-huji population. Both have grown considerably since the mid-1990s.

Figure 68: Beijing Urban Employed Population by Type of Ownership 1978-2007 (millions)

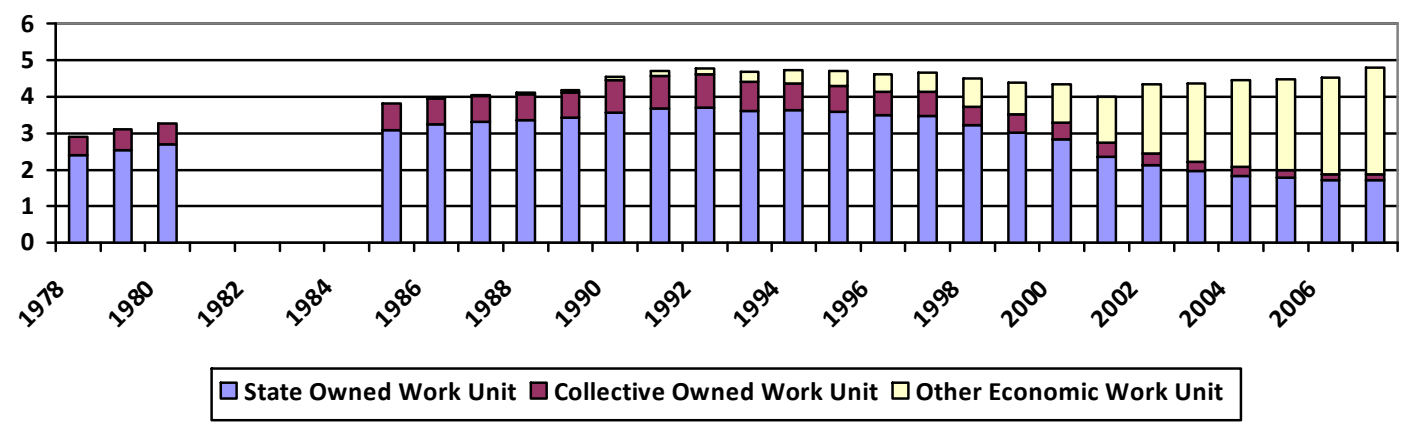

Source: 2008 Beijing Statistical Yearbook, www.bjstats.gov.cn/

Nongmingong now make a significant contribution to the economic development of Beijing in vital industries (see table 22). For this reason it is likely Beijing will continue to have a large non-huji population. With strict controls of the natural growth of the huji 
population and very low inward hukou transfer rates the continued growth of Beijing enterprises requires the non-huji population.

Table 22: Economic Growth Created by Nongmingong in Selected Industries in Beijing (2003)

\begin{tabular}{|c|c|c|}
\hline Industry & Economic Growth (Trillion Yuan) & Created by Nongmingong \\
\hline Construction & 28 & $83 \%$ \\
\hline Manufacturing & 103 & $29 \%$ \\
\hline Wholesale and Retail & 25 & $49 \%$ \\
\hline
\end{tabular}

Source: Beijing City Research Group, Nongmingong Research Report (2006), p.365

Growth of Beijing's non-huji population has contributed half of the total growth in Beijing's population over the period of study. The non-huji population are increasingly long-term residents at destination and make a considerable contribution to the local economy, especially in recent years. The non-huji population are distributed more densely in developing districts surrounding central Beijing. They are predominantly employed in service work and construction. Both their predominantly agricultural hukou status and their non-local status correspond with on average lower wages than the huji and non-agricultural population in Beijing. This corresponds to a lower standard of living. The next section explores the institutional impact the long-term non-huji population is having on the formal arrangements of the Beijing huji institution.

\subsubsection{The Institutional Challenge}

Growth of the non-huji population has contributed significantly to Beijing's economic development but also created new challenges for the Beijing Municipal Government. Over the period of study, Beijing's local authorities have moved from efforts to strictly control the growth of both the huji and non-huji population to efforts to limit hukou transfer though competitive applications and to match the size of the non-huji population with the creation of employment opportunities through economic development. The two most significant reforms to the huji institution in Beijing over the 
period of study are the introduction of temporary residency permits in 1985 and the liberalisation of inward hukou transfer through the introduction of competitive inward hukou transfer categories.

The introduction of temporary permits in 1985 marked a significant deviation from pre1978 norms. Temporary permits, employment permits, family planning certificates, employment cards for outward migration and nationalisation and unification of the huji system has greatly increased the ability of the Beijing City government to govern the floating population. Examples such as the Beijing Olympics, show local government also have the ability to remove the floating population when needed. It is likely in this case temporary permits were not issued for the period of time industry was instructed to close for whilst the Olympics were on. The non-huji population in Beijing is a significant addition to the huji population. Since the mid-90s, growth of the non-huji population has outstripped growth of the huji population. Non-huji residents in Beijing accounted for 4 million of Beijing's 16 million residents in 2007. As the formal institutional rules do not account for the long-term permanent residency of the non-huji population an informal practice has emerged. This informal practice increasingly questions discriminatory practices against non-huji residents and has won concessions in education, employment, housing and social security. As the non-huji population has grown in Beijing, the pressure to adapt the urban bureaucracy geared to the requirements of only the huji population has grown. The Beijing Municipal Government has improved the provision of compulsory education to migrant children, improved workplace safety and labour rights and made more available the provision for social security and insurance. ${ }^{500}$ But challenges still remain. Due to the limits on available employment, competition is high and wages low. Some employers continue to exploit 
the rights of their workers, including, wage arrears (particularly in small enterprises), low use of labour contracts, long work hours, poor conditions and poor safety standards. There remains a general poor provision of social benefits and a lack of participation in insurance schemes by nongmingong. The level of nongmingong taking out workplace accident insurance has increased but the level with general health insurance remains very low. A large amount of nongmingong faced with sickness, a workplace accident or unemployment do not receive adequate treatment. Provision of local government services for the non-huji population has improved in recent years but still fall far short of the benefits of being a Beijing huji resident. This makes hukou transfer an increasingly important issue for Beijing.

Even though hukou transfer remains off-limits to the majority of non-huji residents in Beijing, the interests of a minority of candidates have been met (business investors, skilled personnel, cultural and sporting stars). Hukou transfer decision-making is controlled by local government organs with some central government oversight by the Ministry of Labour and the Ministry of Personnel. These organs limit inward hukou transfer to on average 180,000 applicants per year. Categories are restricted to those with Beijing relatives, government employment or to people who are highly skilled and sought after by local enterprises. The introduction of these meritocratic hukou transfer categories is a significant deviation from both the formal regulations of 1978 and the actual practice of the time. Beijing hukou remain valuable. Because of this value, competitive inward hukou transfer procedures will most likely continue to be used by Beijing officials. But as the non-huji population continues to increase to be more integrated and contribute more to the local economy, it not only calls for improved rights as temporary labourers and temporary residents of Beijing but increasingly as residents deserving of local huji status. 
In conclusion, the Beijing huji institution has emerged as a significant local government policy mechanism for promoting local development. As at the national level, two primary policy tools are used to govern the Beijing population, temporary residency permits and inward hukou transfer. These areas have liberalised to meet the requirements of Beijing's growing private economy. The growth of the non-huji population is increasingly corresponding to more rights as temporary residents and workers but hukou transfer policies remain geared to the richest and most talented employees in Beijing. The final case study seeks to compare Beijing to Shenzhen, a relatively new and rapidly growing city in China with a small huji population and an extremely large non-huji population.

\subsection{Case 3: Shenzhen}

By 2007 Shenzhen had up to 12 million non-huji residents nearly $10 \%$ of China's total non-huji population. This population lived and worked beside a small huji population of 2 million. The non-huji population has grown quickly in a city with a very small huji population and for this Shenzhen has been nicknamed the City of the Migrant Bird. ${ }^{501}$ The non-huji population has grown to account for up to $86 \%$ of the total population. Rapid economic development has been spurred by a potent mix of foreign direct investment (FDI) and rural to urban labour flows creating a mammoth export manufacturing zone. In no other part of China has the use of rural labour flows been more central to the economic development of the city. This model of development has been extremely profitable but it has also come at a cost. Organised labour represents the forefront of the emerging civic rights movement. This movement has had some success in the form of increased protection of the rights of the non-huji population. Shenzhen also has the reputation as being at the forefront of huji reform in China. Reforms have

\footnotetext{
501 候鸟城市.
} 
prioritised competitive inward hukou transfer categories much as in Beijing and inward hukou transfer rates are considerably higher than in Beijing. Even so, inward hukou transfer remains far lower than growth of the non-huji population. This final case study will look briefly at the economic development model, the growth of the huji and nonhuji populations and changes in the formal rules governing hukou transfer and residence in Shenzhen.

\subsubsection{Migrant City}

In 1979, Baoan County was renamed Shenzhen Municipality and in 1980 it became a Special Economic Zone (SEZ). In 1981 the central government promoted Shenzhen to sub provincial status and in 1988 the State Council made it a separate planning city with provincial level economic management status. Shenzhen was chosen to be a SEZ for its location in the Pearl River Delta and close proximity to Hong Kong. Annual economic growth from 1979 to 2007 averaged $28 \% .^{502}$ This growth has been fuelled by foreign direct investment which grew to 4 trillion USD by 2008 (see figure 69). Shenzhen's production rate grew to 800 trillion Yuan by 2008 (see figure 70). These economic successes have been achieved through rapid growth over the period of study, particularly in the early years of reform (see figure 71 ).

Figure 69: Foreign Direct Investment in Shenzhen 1978-2008 (trillion, USD)

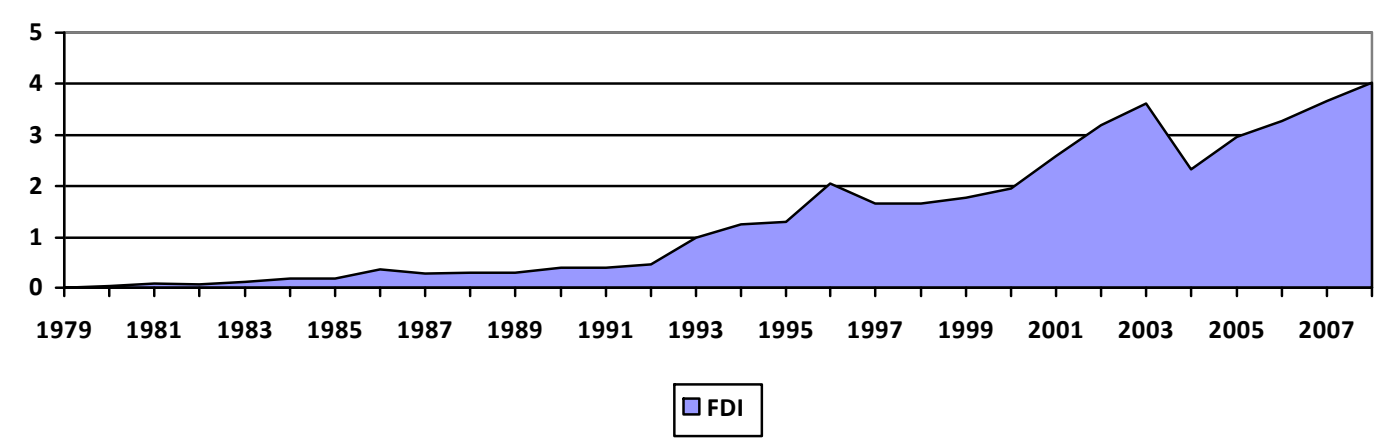

Source: Shenzhen Statistical Bureau, www.sztj.com/

\footnotetext{
${ }^{502}$ Saifeng Wu, Xiaogu Song, and Bo Zeng, "Shenzhen: Lonestar of China's Reform and Opening-Up," (Beijing: China Today, 2008). http://www.chinatoday.com.cn/English/e2008/e200812/p40.htm.
} 
Figure 70: Shenzhen Production 1979-2008 (trillion Yuan)

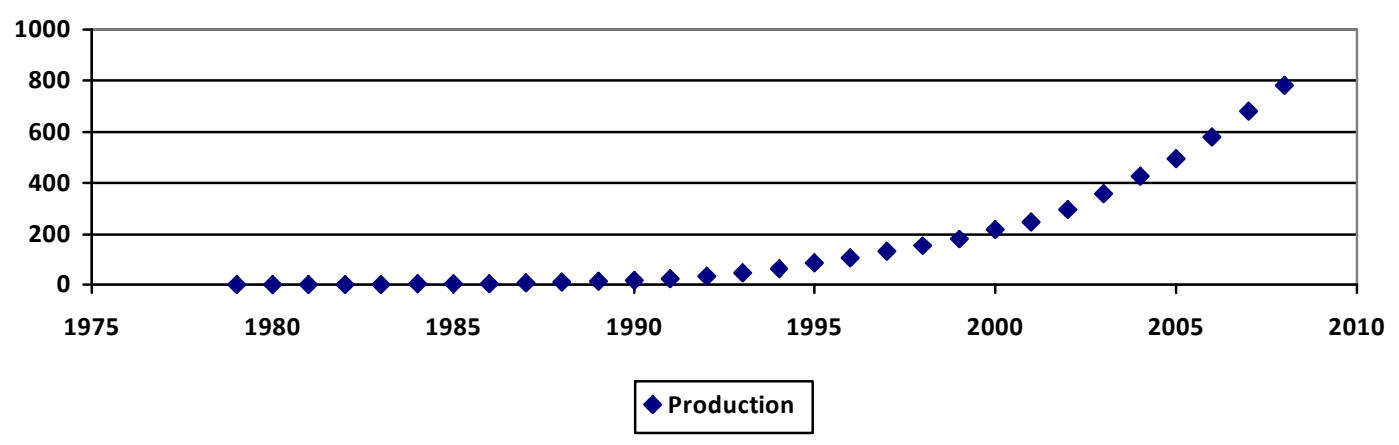

Source: Shenzhen Statistical Bureau, www.sztj.com/

Figure 71: Shenzhen Production Growth Rate 1980-2008 (\%)

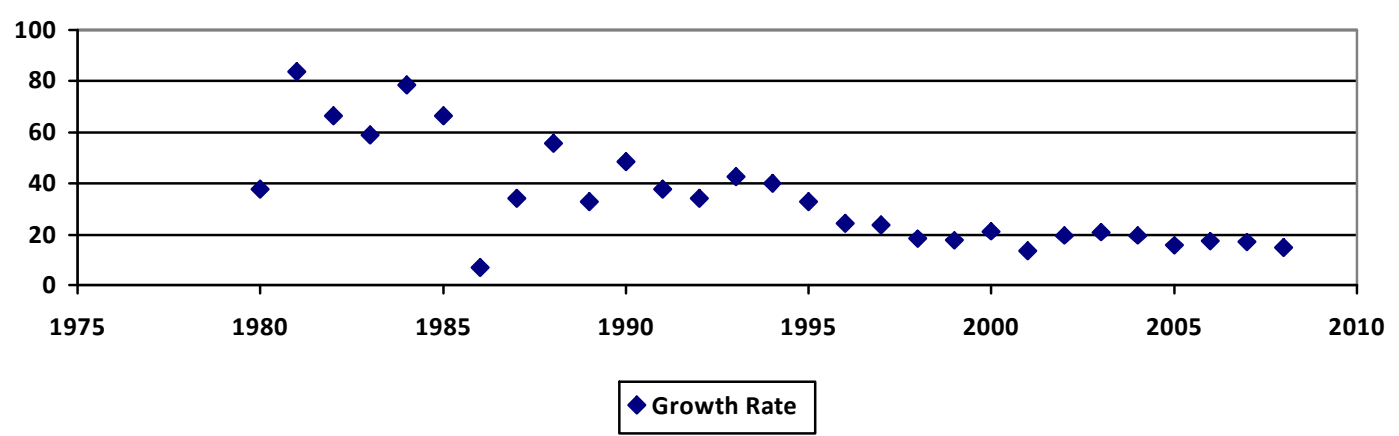

Source: Shenzhen Statistical Bureau, www.sztj.com/

The huji population has grown considerably over the period of study. In 1979 it was only 300,000. This grew to 2 million by 2007 (see figure 72). Growth of the huji population has been remarkably steady in light of the rapid economic development and the large non-huji population.

Figure 72: Shenzhen Huji Population 1979-2007

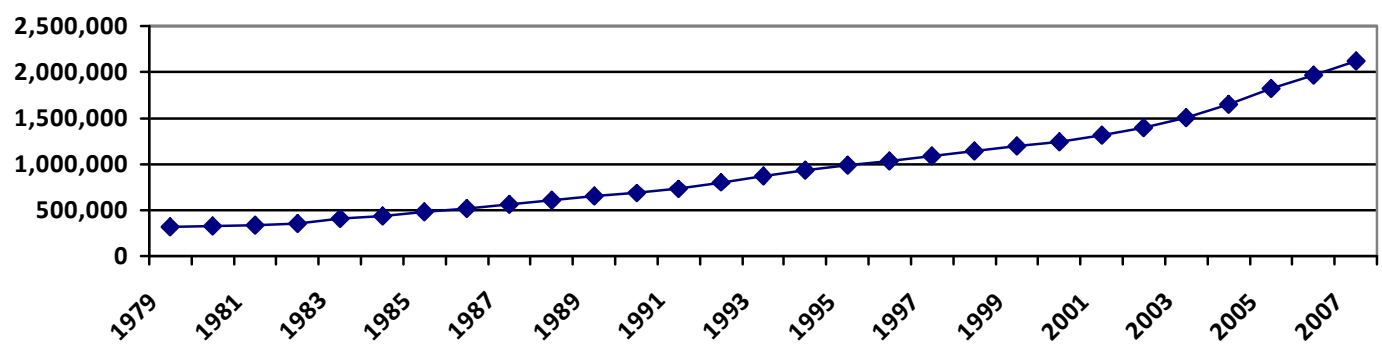

Source: Shenzhen Statistical Bureau, www.sztj.com/ 
Growth of the Shenzhen huji population is due to both a high rate of natural growth and growth through inward hukou transfer. The municipal plan for 2008 outlined a series of population targets including targets for the huji population to grow by 160,000 people of which 125,000 were to be through skilled and investor inward hukou transfer and 35,000 through natural growth. ${ }^{503}$ In 2008 Shenzhen planned an annual inward hukou transfer $6.25 \%$ the size of the existing huji population. This is far higher than Beijing's inward hukou rate of $1.5 \%$ the size of the Beijing huji population. This suggests developing cities with small huji populations and large non-huji populations are more likely to have a higher rate of inward hukou transfer than established cities with a large existing huji population and lower proportion of non-huji residents. As Shenzhen is a developing city geared to export processing and manufacturing there is likely more opportunity for inward hukou transfer of skilled personnel and business investors required to develop the city than in Beijing with a large established huji population.

The use of migrant labour has been a most remarkable feature of Shenzhen's economic development model. Private industry has grown through a constant flow of FDI attracted by the preferential policies in the Shenzhen SEZ. This led to increased opportunities for rural migrants to work in Shenzhen and since the early 1980s millions of migrants have come to work and reside in the city. The vast majority come from rural areas and fail to transfer their permanent hukou to Shenzhen, instead being issued temporary permits allowing them to work and reside in Shenzhen temporarily. By 1989, the non-huji population had outgrown the huji population and since that time Shenzhen's population has been made up predominantly of non-huji residents. Various estimates put the number of non-huji residents at different levels. The larger estimates

\footnotetext{
${ }^{503}$ Chen Biao 陈彪. 《关于深圳市 2007 年国民经济和社会发展计划执行情况与 2008 年计划 (草 案）的报告》[Draft Report Regarding the Implementation of the Shenzhen City 2007 Socio-Economic Development Plan and the 2008 Plan]. edited by 深圳市发展和改革 [Shenzhen Bureau of Development and Reform]. 深圳 [Shenzhen]: 深圳市政府 [Shenzhen Municipal Government], 2008.
} 
state that by 2008 Shenzhen had a total population of 14 million, of which only 2 million were huji residents and 12 million were non-huji residents. ${ }^{504}$ The Shenzhen Municipal Statistic Bureau estimated the total population of Shenzhen as 8.6 million in 2007 of which only 2.1 million had local huji status. From less than a million non-huji residents in 1990, the temporary population had grown to nearly six and a half million by 2007 (see figure73). Figure 74 shows the widening gap between the size of the huji and non-huji populations.

\section{Figure 73: Non-Huji Population in Shenzhen 1979-2007}

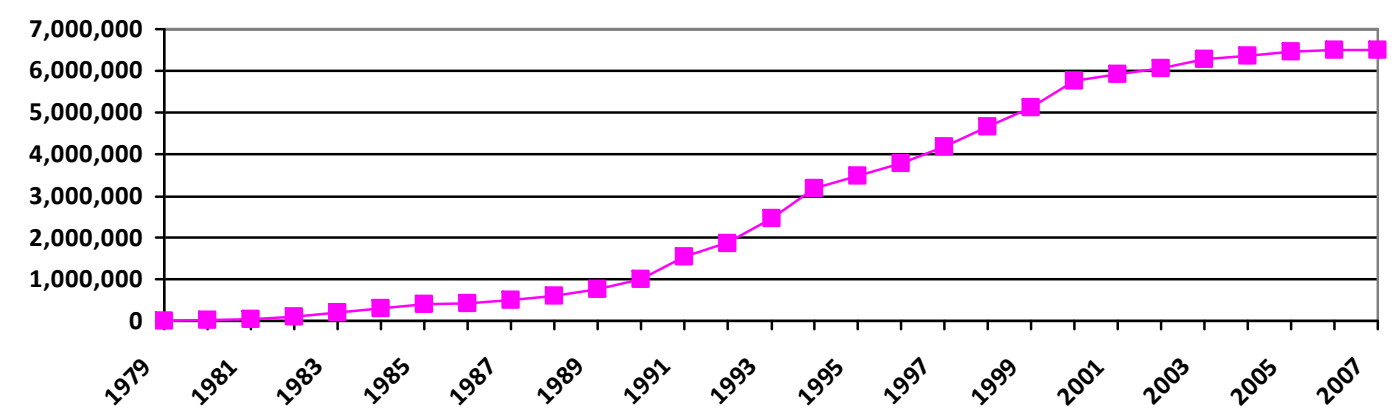

Source: Shenzhen Statistical Bureau, www.sztj.com/

Figure 74: Huji and Non-Huji Population in Shenzhen 1979-2007

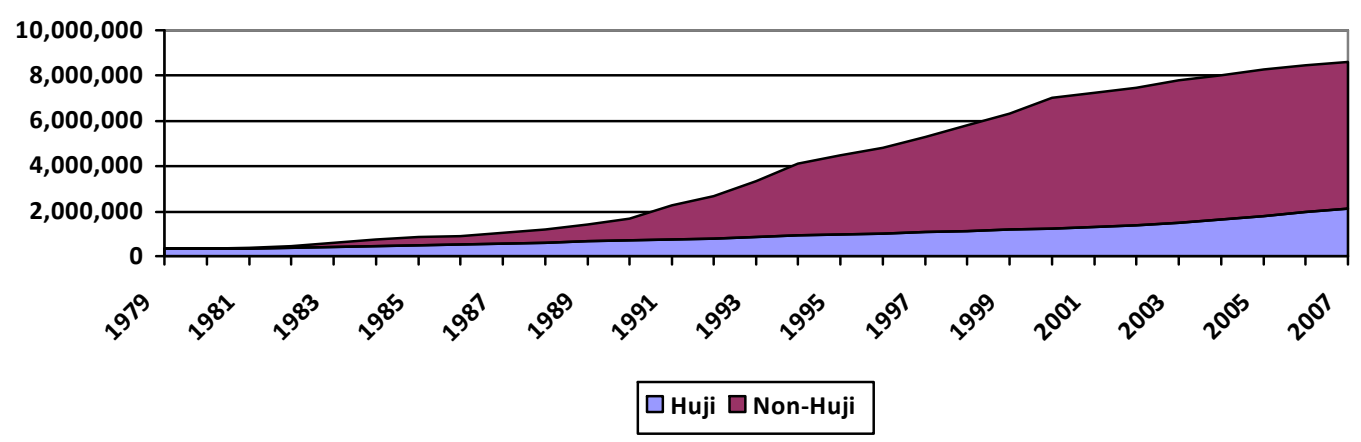

Source: Shenzhen Statistical Bureau, www.sztj.com/

Shenzhen's huji and non-huji populations are not distributed evenly across the various districts of Shenzhen. Figure 75 shows the location of the huji and non-huji populations by district. Baoan accounts for $46 \%$ of the non-huji population ( 3 million) and

504 Zhong Liang 钟良. “深圳户籍体制变革 “一市两制”户籍管理终结” [Shenzhen Huji System Transformation: 'One City Two Systems' Huji Management Structure]. 《21 世纪经济报道》[21st Century Business Herald], 2008. 
surrounds the inner city. Both Baoan and Longgang are regions of Shenzhen that have a high proportion of non-huji residents, most of whom are employees in the service and tertiary sector industries of the SEZ.

Figure 75: Location of Huji and Non-Huji Populations in Shenzhen in 2007 (millions)

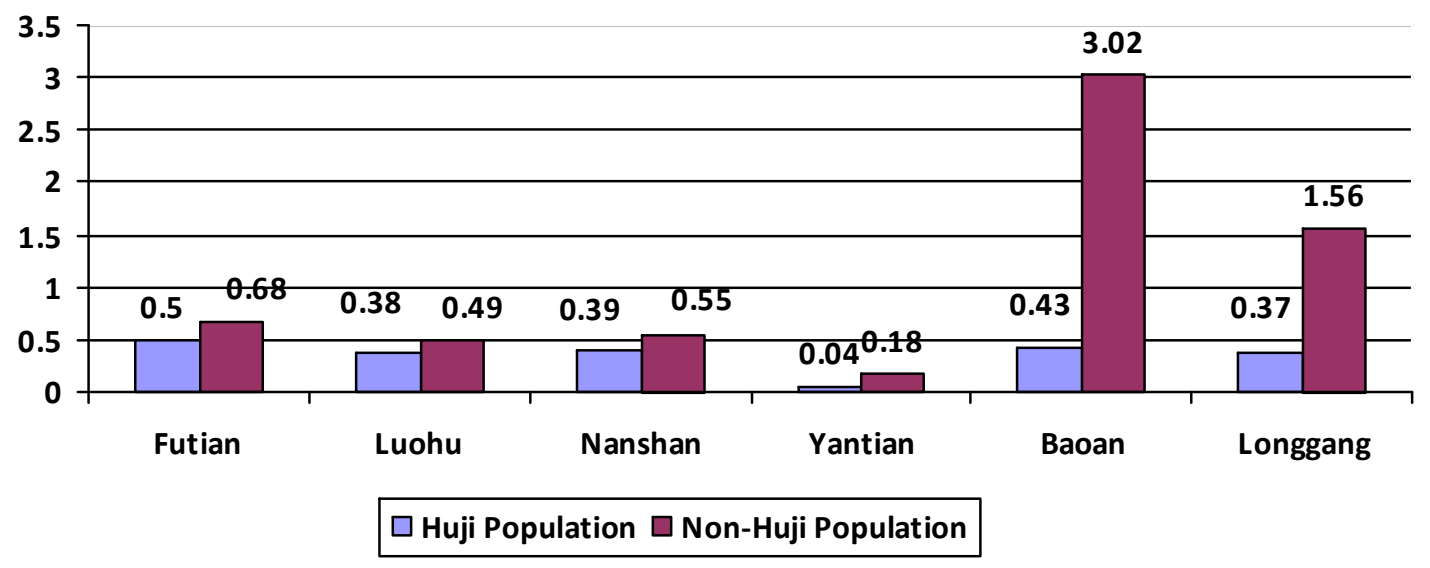

Source: Shenzhen Statistical Bureau, www.sztj.com/ ${ }^{505}$

With a high rate of population growth through migrant labour and a relatively unestablished huji population the conditions for huji reform remain more favourable than in Beijing. It is expected that a less established city with rapid economic development and a well formed labour market will also have a more liberalised huji management system. More precisely, the huji system will have adapted more to the new socioeconomic rationales of reform China and be less influenced by conservative and traditional uses of the huji system. The following section tests this claim by briefly reviewing the huji reform process in Shenzhen to see if the rhetoric of reform corresponds to significant liberalisation as claimed by local and central government.

\subsubsection{Emerging Huji Regulations}

Shenzhen has been at the forefront of huji reform. Local authorities allowed and encouraged temporary residency for employment very early in the reform era. Temporary labour migration makes up a majority of the employment opportunities in

505 Shenzhen City 2007 Economic and Social Development Statistics Bulletin 深圳市 2007 年国民经济 和社会发展统计公报. 
Shenzhen. The Shenzhen Municipal Government also introduced the Shenzhen blue chop hukou in the mid-1990s and has liberalised hukou transfer through the addition of competitive inward hukou transfer categories. Officials in Shenzhen made these reforms earlier than officials in Beijing and in other parts of China. The reforms in Shenzhen have also been taken further with a higher rate of inward hukou transfer relative to the size of the huji population. Inward hukou transfer rates are significantly higher than in Beijing. Whilst Shenzhen is a model of advanced huji reform in China the type of reforms that have been introduced are not significantly different to those in other areas of China. Shenzhen local authorities still maintain huji non-huji divisions and insulated decision-making for inward hukou transfer applications.

The local government began liberalising non-huji residency in Shenzhen for the purposes of employment in the early 1980s. Along with the tax concessions and more liberal economic regulations, Shenzhen municipal authorities were given a degree of freedom to experiment with market-orientated regulations. Shenzhen's small huji population required a large non-huji population to translate the high rates of FDI and local capital into production. This required liberalisation of the huji institution to allow and encourage rural labour migrants into Shenzhen. Early recognition that non-huji residency in Shenzhen was beneficial for Shenzhen's economic development was made easier by the fact the huji population was so small. As one of the earliest cities to allow non-huji residency, Shenzhen local authorities were also the first to face the challenge of adapting the huji institution to the influx of large numbers of unskilled labourers. Liberalisation of non-huji residency and employment in Shenzhen has also led to reforms in other areas. A series of local government challenges concerning health insurance, social security, education for migrant children and employment rights and labour standards became apparent early on in Shenzhen as the non-huji population 
quickly came to number more than the huji population. The local government response has been to incrementally strengthen employment regulations and improve conditions for the temporary population and remove some non-huji discrimination in education, insurance, social security and employment. As in other parts of China, the Shenzhen Public Security Bureau has made efforts to improve its registration, surveillance and governance of Shenzhen's non-huji population and to match the size of the temporary population to the number of employment opportunities in local industry. The vast difference between local government estimates of the non-huji population and the 2000 Census results suggests the size of the unregistered temporary population remains large and that there are mixed results in local government efforts to match the size of the temporary population to the growth in legal employment opportunities.

The Standing Committee of the Shenzhen City People's Congress issued the Shenzhen Special Economic Zone Temporary Personnel Management Regulations in 1995. ${ }^{506}$ This formalised registration requirements of the non-huji population and required local enterprises to work closely with the Shenzhen Public Security Bureau. Applications for work permits and temporary residency permits could be applied for in person or through a local enterprise. Application categories were focused on granting temporary residency to those people with employment in Shenzhen, who were renting accommodation in Shenzhen or who had relations with other Shenzhen residents.

Table 23: Temporary Hukou Registration Details (1995)

\begin{tabular}{|rl|}
\hline 1. & Name and Gender \\
\hline 2. & Resident Identification Card Number \\
\hline 3. & Permanent Hukou Address \\
\hline 4. & Temporary Address \\
\hline 5. & Duration of temporary stay \\
\hline 6. & Reason for temporary stay \\
\hline 7. & Any other important information \\
\hline
\end{tabular}

Source: Shenzhen SEZ Temporary Personnel Management Regulations, CH2, Article 6

506 《深圳经济特区暂住人员户口管理条例》, 深圳市人大常委会. 
Also in 1995 the Shenzhen Municipal Government issued Interim Provisions for Huji System Reform in Shenzhen City. ${ }^{507}$ The main focus of the interim provisions was to continue to 'control population growth, refine the population structure and raise the quality of the population' by systematising huji management of 'temporary hukou', 'blue chop hukou' and 'permanent hukou' ${ }^{508}$ Control of huji population growth and employment in the city was to confer with the level of development in the special economic zone and apply the principle of 'first city then non-local'. ${ }^{509}$ Baoan and Longgang, the two districts identified in the previous section as having a majority of the non-huji population in Shenzhen (4.5 million or $70 \%$ ), are directed to punish noncompliance with huji regulations. The Shenzhen Personnel Bureau and the Shenzhen Labour and Social Security Bureau are identified as managing hukou transfer applications and management and the Shenzhen Public Security Bureau is identified as the main department managing huji records and regulations. Conditions for inward hukou transfer stress employment, home ownership and business investment in Shenzhen. These regulations also introduced the Shenzhen blue chop hukou. ${ }^{510}$

Shenzhen's blue chop hukou represents another institutional category created by local officials. The blue chop hukou is a status more local than that accorded with a temporary residency permit but not the same as local huji residency. It was designed to grant a form of residency to a select group of candidates in the non-huji population investing in Shenzhen or employed by a local work unit for at least a year. Non-huji residents of Baoan and Longgang districts under the age of 45, with a good huji record and skilled employment were singled out for blue chop hukou transfer. There were three general categories of applicants based on length of residency in Shenzhen and the

507 《深圳市户籍制度改革暂行规定》.

508 “控制人口增长、优化人口结构、提高人口素质” ; 暂住户口、蓝印户口、常住户口.

509 “先市内后市外”.

510 蓝印户口。 
qualifications and skills of the applicant (see table 24). Non-huji residents investing over 1 million Yuan could also apply for the blue chop hukou. ${ }^{511}$

Table 24: Shenzhen Blue Chop Hukou Applicant Conditions (1995)

\begin{tabular}{|c|ll|}
\hline $\begin{array}{c}\text { Applicants residing in } \\
\text { Shenzhen for more than } \\
\text { three years }\end{array}$ & $\begin{array}{l}\text { - } \\
\text { - }\end{array}$ & $\begin{array}{l}\text { Mid level vocational education } \\
\text { or holder of a basic skills certificate from Shenzhen City Labour Bureau }\end{array}$ \\
\hline $\begin{array}{c}\text { Applicants residing in } \\
\text { Shenzhen for more than } \\
\text { two years }\end{array}$ & $\begin{array}{l}\text { - } \\
\text { - }\end{array}$ & $\begin{array}{l}\text { High level vocational education } \\
\text { or holder of assistant level professional skills certificate } \\
\text { or holder of a advanced skills certificate from Shenzhen City Labour }\end{array}$ \\
\hline $\begin{array}{c}\text { Applicants residing in } \\
\text { Shenzhen for more than } \\
\text { one year }\end{array}$ & $\begin{array}{l}\text { - } \\
\text { - }\end{array}$ & $\begin{array}{l}\text { Ondergraduate university degree } \\
\text { or holder of a mid level vocational certificate }\end{array}$ \\
\hline $\begin{array}{l}\text { Bureau advanced skills certificate from Shenzhen City Labour } \\
\text { or holder of a Basic National Administration Cadre Certificate } \\
\text { or holder of Shenzhen City government award }\end{array}$ \\
\hline
\end{tabular}

Source: Interim Provisions for Huji System Reform in Shenzhen City, CH3, Article 18

Blue chop hukou applications were to be decided within these guidelines and in accordance with the following principle, 'prioritise enterprises with good returns; prioritise talented people in skilled professions (production); prioritise people of high quality and good appearance'. ${ }^{512}$ Local officials were to issue blue chop hukou in line with the requirements for skilled labour in the special economic zone. Blue chop hukou were significantly more beneficial than temporary residency permits because they gave the holder the same rights as Shenzhen's huji residents in areas such as social security and medical insurance, business application licenses, immigration and examinations. It also allowed spouse and siblings to gain the same hukou as the main applicant. Residents of Shenzhen issued the blue chop hukou were then in a position to apply for permanent huji residency. Non-huji residents of Shenzhen below 45 and with a good huji record as well as blue chop hukou holders in Baoan and Longgang with a good blue

\footnotetext{
511 Interim Provisions for Huji System Reform in Shenzhen City, CH3, Article 20.

${ }^{512}$ Interim Provisions for Huji System Reform in Shenzhen City, CH3, Article 25; “企业效益好的优 先、急需专业（工种）的人才优先、表现好素质高的优先”.
} 
chop hukou record could apply for permanent hukou transfer. Conditions on hukou transfer were high and only applied to the most successful of the non-huji population in Shenzhen (see table 25).

Table 25: Shenzhen Inward Hukou Transfer Conditions (1995)

\begin{tabular}{|c|c|}
\hline $\begin{array}{l}\text { Applicants holding a } \\
\text { Shenzhen blue chop } \\
\text { hukou for more than } \\
\text { three years }\end{array}$ & - No conditions specified \\
\hline $\begin{array}{l}\text { Applicants holding a } \\
\text { Shenzhen blue chop } \\
\text { hukou for more than two } \\
\text { years }\end{array}$ & $\begin{array}{l}\text { - High level vocational education } \\
\text { - or holder of an intermediate skills certificate from the Shenzhen City } \\
\text { Labour Bureau }\end{array}$ \\
\hline $\begin{array}{l}\text { Applicants holding a } \\
\text { Shenzhen blue chop } \\
\text { hukou for more than one } \\
\text { year }\end{array}$ & 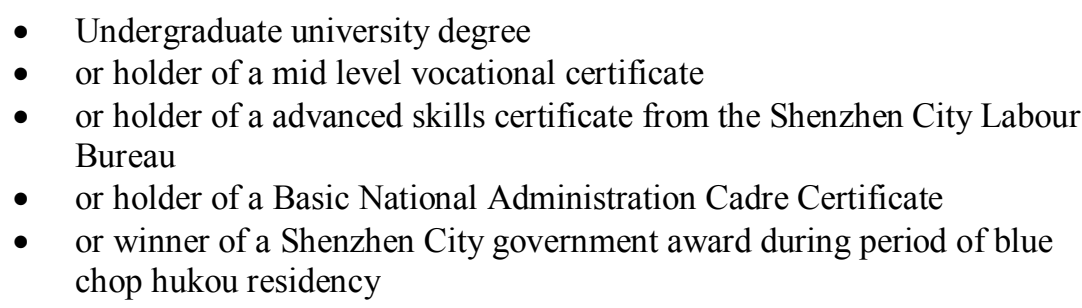 \\
\hline
\end{tabular}

Source: Interim Provisions for Huji System Reform in Shenzhen City, CH4, Article 19

The introduction of Shenzhen blue chop hukou created a different institutional category to the national norm. Chinese citizens in Shenzhen could be temporary permit non-huji residents, non-huji residents holding blue chop hukou or permanent Shenzhen hukou holders. Shenzhen local authorities made further efforts to encourage skilled employees and graduates to work in Shenzhen in 2003 with the introduction of the 'Shenzhen City Residency Permit for the Talented'. ${ }^{513}$ This and the Shenzhen blue chop hukou introduced further institutional categories which acted as buffers on the growth of the huji population. The temporary residency category also functioned as a buffer on huji population growth by allowing non-huji population growth but maintaining strict hukou transfer regulations. Conditions for applying for both blue chop hukou and inward hukou transfer liberalised earlier than in Beijing. By the mid-1990s hukou transfer had

513 深圳市人才居住证. 
already begun to prioritise hukou transfer deemed by local officials to be in the interests of the economic development of the city. These interests prioritised investment in Shenzhen and skilled and talented employees, particularly those with production related skills. Hukou transfer regulations have continued to prioritise investment and skills throughout the late 1990s and early 2000s.

\subsubsection{Contemporary Hukou Transfer Regulations}

Shenzhen local authorities have liberalised inward hukou transfer more than other cities in China. Inward hukou transfer is set at an annual rate around $6 \%$ the size of the huji population. This is significantly higher than Beijing's 1.5\% growth through inward hukou transfer. The Shenzhen Municipal Public Security Bureau maintains hukou regulations that have followed the mid-1990s model of granting temporary residency to non-huji residents engaged in low-end employment and granting inward hukou transfer only to those with skill sets required by Shenzhen industries or those investing large amounts of capital in a Shenzhen industry. Experiments with blue chop hukou have not diminished the long-term desire of non-huji permanent residents in Shenzhen to gain inward hukou transfer. As in Beijing, permanent hukou transfer reforms have introduced conditions aimed at attracting investors and skilled personnel whilst maintaining categories for people in government, those with relatives in Shenzhen and for students whilst studying in Shenzhen (see table 26). Due to the relatively small size of the Shenzhen huji population it is likely inward hukou transfer rates are not dominated by the relative category to the same extent as other cities with established populations. It is also likely the high rate of inward hukou transfer is partly attributable to the proportionately large size of the non-huji population. As in other parts of the world, what was originally intended by local officials as temporary labour migration is actually creating a non-huji permanent resident population. This population is increasingly pressuring local officials for the opportunity for inward hukou transfer. 
Table 26: Shenzhen Inward Hukou Transfer Categories (2007)

\begin{tabular}{|c|c|}
\hline \multirow{3}{*}{$\begin{array}{l}\text { Government and military } \\
\text { personnel }\end{array}$} & $\begin{array}{c}\text { Inward hukou transfer for retiring military personnel } \\
\text { 退伍军人入户 }\end{array}$ \\
\hline & $\begin{array}{c}\text { Inward hukou transfer for transferring military cadres } \\
\text { 军队转业干部入户 }\end{array}$ \\
\hline & $\begin{array}{c}\text { Inward hukou transfer for spouse and children accompanying } \\
\text { retiring military personnel } \\
\text { “随军” 配偶、子女随迁入户 }\end{array}$ \\
\hline \multirow{4}{*}{$\begin{array}{l}\text { Investors, employees, } \\
\text { foreigners and overseas } \\
\text { Chinese nationals }\end{array}$} & $\begin{array}{l}\text { Inward hukou transfer for investors and taxpayers } \\
\text { 投资纳税入户 } \\
\end{array}$ \\
\hline & $\begin{array}{l}\text { Inward hukou transfer for personnel from Hong Kong and Macao } \\
\text { 港、澳人员入户 }\end{array}$ \\
\hline & $\begin{array}{c}\text { Inward hukou transfer for Taiwan compatriots, overseas Chinese, } \\
\text { foreigners becoming Chinese nationals and other personnel } \\
\text { 台湾同胞、华侨、加入中国籍的外国人等人员入户 }\end{array}$ \\
\hline & $\begin{array}{c}\text { Inward hukou transfer for recruited personnel } \\
\text { 招调人员入户 }\end{array}$ \\
\hline \multirow{4}{*}{ Education } & $\begin{array}{c}\text { Inward hukou transfer for Shenzhen City higher education Students } \\
\text { 本市普通高等学校录取新生户口迁入 }\end{array}$ \\
\hline & $\begin{array}{c}\text { Inward hukou transfer for vocational school graduates } \\
\text { 大中专院校毕业生入户 }\end{array}$ \\
\hline & $\begin{array}{c}\text { Inward hukou transfer upon completion of doctorate } \\
\text { 博士后户口迁移 }\end{array}$ \\
\hline & $\begin{array}{l}\text { Inward hukou transfer for attracting overseas exchange students } \\
\text { 国外引进留学生入户 }\end{array}$ \\
\hline \multirow{7}{*}{$\begin{array}{l}\text { Spouses and dependents of } \\
\text { huji residents }\end{array}$} & $\begin{array}{c}\text { Inward hukou transfer for newborn within policy guidelines } \\
\text { 政策内出生婴儿入户 }\end{array}$ \\
\hline & $\begin{array}{c}\text { Inward hukou transfer for newborn outside of policy guidelines } \\
\text { 政策外出生婴儿入户 }\end{array}$ \\
\hline & $\begin{array}{c}\text { Inward hukou transfer for child of Shenzhen resident abroad } \\
\text { 本市居民在国外出生的子女入户 }\end{array}$ \\
\hline & $\begin{array}{c}\text { Inward hukou transfer for child of Shenzhen resident overseas } \\
\text { 本市居民在港澳出生子女入户 }\end{array}$ \\
\hline & $\begin{array}{l}\text { Inward hukou transfer for children of military personnel } \\
\text { 双军人子女出生入户 }\end{array}$ \\
\hline & $\begin{array}{c}\text { Inward hukou transfer for foster children } \\
\text { 本市居民收养的非社会福利机关抚养的弃婴（童）出生入户 }\end{array}$ \\
\hline & $\begin{array}{l}\text { Inward hukou transfer for those accompanying applicant } \\
\text { 随迁入户 }\end{array}$ \\
\hline
\end{tabular}

Source: Shenzhen Municipal Public Security Bureau Website ${ }^{514}$

Because employment conditions and treatment are generally very low, a steady stream of migrants is expected to enter and then leave Shenzhen after working temporarily. This is a model for sustained rapid economic growth but not a model for sustainable cities. Many cities in China now try to emphasise their better work and living conditions and view Shenzhen as a model not to follow. ${ }^{515}$ Even so, Shenzhen's migrants are

${ }^{514}$ Shenzhen City Public Security Bureau 深圳市公安局. 《人口管理》 [Population Management]. 深圳 市 [Shenzhen]:深圳市公安局 [Shenzhen City Public Security Bureau ], 2007.

${ }_{515}$ Howard W. French, "Chinese Success Story Chokes on Its Own Growth," New York Times, December 19 2006, http://www.nytimes.com/2006/12/19/world/asia/19shenzhen.html. 
unlikely to all be temporary. These long-term non-huji residents represent an emerging civic rights movement that has significant political implications for local governance in Shenzhen. The labour movement has been at the forefront of seeking greater rights for the non-huji population but there is also a broader question of civic rights for long-term non-huji residents. For example, the huji institution presents a barrier to local body representation of the non-huji permanent population. This is shown by a case in 2005 in which a long time 'resident' of Shenzhen who did not have local hukou wanted to run as a candidate to be a representative on a local Resident Committee. ${ }^{516}$ The candidate was rejected because he was not a 'local resident'. The case went to court seven times and each time the claimant was denied the right to stand for representation. This means the majority of people living in Shenzhen are denied the right to represent their communities and participate proactively in the political process because they do not have local resident status in areas where they reside and work for long periods of time. China's future political reforms will need to take account of huji status when implementing local body representation.

In conclusion, Shenzhen's model of population management is unique for China. This is due to its central role as an export and processing area for national and foreign companies. Shenzhen survives on a steady supply of cheap labour. Whereas Beijing limits the flow of temporary labour to meet the development requirements of the city, Shenzhen's insatiable thirst for migrant labour has created the most extreme hukou/nonhukou population proportions in China (60-85\% non-huji). Shenzhen's huji management has significantly liberalised the growth of the migrant labour population in an all out effort to be one of China's most important production zones. Hukou transfer has remained limited but Shenzhen has led the national reform trends by introducing

\footnotetext{
${ }^{516}$ Li Guiru 李桂茹. "深圳一非户籍居民：选举权与他若即若离" [A Non-Huji Resident in Shenzhen: The Right to Stand for Election Kept at Arm's Length] 《中国青年报》 [China Youth Paper], 2005, http://news.xinhuanet.com/legal/2005-06/16/content_3091566.htm.
} 
residency schemes that limit hukou transfer to China's most talented employees and business investors. The introduction of the blue chop hukou in the mid-1990s was also a significant deviation from huji management in other urban areas of China and represents a local government trend towards staggered and competitive inward hukou transfer regulations. Huji reforms in Shenzhen suggest liberalisation is occurring incrementally in China and that local government will continue to manage growth of the huji and nonhuji populations in the interests of city development for some time to come.

\subsection{Conclusion}

These two case studies at the local government level show there is both consistency and difference in huji policy over various regions in China. Localisation of huji decisionmaking has allowed greater diversity in huji policy as local governments use it to promote local development under varying socio-economic conditions. Beijing is an old established city that had a large existing permanent population at the beginning of the reform era. Shenzhen by comparison was a small 'village' of 300,000 people. Both cities have had exceptional economic growth creating employment opportunities for temporary migrants. Shenzhen has a workforce dominated by non-huji residents but Beijing's workforce is still dominated by huji residents. Beijing has a long legacy of strict hukou transfer controls and local authorities have shown more resistance to liberalising huji transfer. Shenzhen by comparison is a young city with a small huji population. Growth of the non-huji population has been central to the economic development of the SEZ. Liberalisation of temporary migration and hukou transfer has been more pronounced in Shenzhen.

This suggests a greater path dependency in areas where the institution has been used as a governing tool for longer periods of time and there is an established huji population far greater in size than the non-huji population. In areas of China with high employment 
opportunities for unskilled labourers there is a corresponding liberalisation of the formal regulations guiding huji management at the local level. These changes include liberalisation of non-huji residency for the purpose of employment and early liberalisation of inward hukou transfer through the addition of competitive hukou transfer categories. Decision-making remains within local government with some ministerial oversight from the Ministry of Labour, Ministry of Public Security and the Ministry of Personnel. Local officials remain central to the decision-making process but increasing marketization of huji management is evidenced by the increasing commonality of non-huji residents in these two urban centres and the introduction of competitive hukou transfer policies. The final chapter presents and discusses the main findings of the study from which a model of institutional change is constructed. 


\section{Discussion and Conclusion}

The primary focus of this study has been on identifying and explaining changes in the formal regulations of China's huji institution from 1978 to 2007. The historical institutionalist and inductive methodology has focused on change over time and highlighted the importance of a number of socio-economic factors occurring over the same period. The intention of this study has been to explain the formal rules of the huji institution, to show how a number of important exogenous and endogenous factors have influenced informal practises of the institutional actors and enforcers and to link this to changes in the formal institutional arrangements. A model of formal institutional change in the huji system has been constructed from these observations.

The major findings of this study are that the huji institution remains an important intervening variable for urbanisation and the developing urban labour markets, that there has been considerable liberalisation of regulations managing labour flows through the introduction of temporary residency permits and some liberalisation of hukou transfer rates and categories through the introduction of competitive hukou transfer. Hukou transfer and temporary residency decision-making have been decentralised. Local officials at the city and provincial level issue their own policies, guidelines and planning goals and have the power to formulate huji regulations to meet the requirements of development in their region. Local officials have maintained the huji regulations in an effort to accomplish the institutional objectives to promote economic development, maintain social stability, manage and restrict migration and urbanisation and strengthen the party-state. These overarching goals of huji management exhibit strong continuity over the reform era and have been maintained and in some cases strengthened by local officials. There is also evidence of considerable and growing variance in the construction and enforcement of the formal regulations of the huji 
system used to meet these objectives compared to the pre-reform era. The liberalisation of non-huji residency and inward hukou transfer are two such examples of significant reform of the formal institutional arrangements. An explanation for these changes can be found in the socio-economic changes occurring in China over the reform era as well as the changing norms of Chinese policymakers. Formal changes have come about through a combination of growth of unskilled employment opportunities in urban sectors, growth of the market economy and increasing rural/urban and east/west economic disparity that has led to divergent actor behaviour.

This chapter is structured into three main sections and a concluding section. The first section presents the major findings of the study in three parts, case 1, cases 2 and 3 and a focus on the major continuities and changes identified. The second section takes these findings and develops a model of institutional change. The major focus here is on generalising patterns of formal institutional change. Examples from the change identified in this study are used to explain and illustrate these processes. The third section takes these findings and revisits the theoretical studies identified in the literature review. The first part focuses on economic models of migration before shifting to a critique of the influential work of Solinger (1999) and Wang (2005). This is then followed by a more general discussion of theories of institutional change. Lastly, some of the shortcomings of this research are explored and future research tracks identified. The final section of the chapter concludes the thesis.

\subsection{Major Findings}

This section presents the major findings of the study. It is structured into three parts. The first part summarises the results from the first case study at the national level focusing on the changing use of the huji institution to meet the institutional objectives to accelerate economic development, maintain social stability, restrict and mange 
urbanisation and maintain the governance structure of the party-state. The second part summarises the findings from the second and third case studies at the local level in Beijing and Shenzhen. The main focus of these results is a comparison of emerging huji regulations in differing socio-economic regions of China. This comparison presents the main similarities and the significant differences found and offers an explanation for these differences. The final part of this section presents the main findings relating to the question of institutional change. This focuses on the variables identified in the literature review and presents the most significant formal institutional changes over the period of study. This then leads into the next section which incorporates these results into a model of institutional change.

\subsubsection{Major Findings from Case 1: China}

Temporary residency permits were introduced after outside the plan migration had already begun to grow. These temporary permits gave local authorities more control over the growing non-huji population and provided local industry with greater and legal access to a large quantity of cheap rural labourers. This rural labour in urban China contributed significantly to the production growth rate and the overall economic development of urban areas. This suggests outside the plan migration is both a driver and a product of the marketization of China. Even in the early days of reform, when China's economy was still heavily planned, a small amount of 'outside the plan' migration conferred with the classic economic rationales for migration and the theoretical assumptions of the Lewis Transition: wage disparity between rural and urban areas, lack of employment opportunities in rural areas and growing low-end employment opportunities in urban areas leads to rural to urban migration in developing economies. These economic rationales drove early migrations and preceded the reforms introducing temporary residency permits in 1985. Temporary permits provided local authorities with an enforceable regulation for temporary residency and employment. 
This gave them greater control over the size and makeup of the temporary population and some ability to match the size of the temporary population to employment opportunities. As local governments decreased the level of state provision for housing, employment and health, the division between the local huji population and the non-huji 'temporary' population decreased. This allowed non-huji residents to survive in urban areas where previously they could not. ${ }^{517}$ This migration has significantly contributed to China's economic development and greatly increased China's global competitive advantage through the introduction of a highly productive rural workforce to urban industry that was absent prior to the reform era.

This follows the classic Lewis Transition assumption that labour will flow from rural to urban industries in developing economies. The proportion of people employed in the primary sector dropped from $70 \%$ in 1978 to $40 \%$ in 2007 . Employment in the secondary and tertiary sectors grew whilst employment growth in agriculture stagnated and then decreased. At the same time GDP growth has been dominated by growth in the secondary and tertiary sectors. This has led to a great convergence with developed countries. Unleashing China's rural labour force significantly contributed to the rapid economic growth experienced. This has been especially apparent since the early 1990s but the process began in the late 1970 s prior to significant formal reform. In the mid1990s China's non-huji population exploded, tertiary and secondary industries grew rapidly and China emerged as an important economy on the global stage largely due to its export-led growth model dominating consumer markets for low-end products in developed and developing countries. These findings confirm earlier studies but differ as they also point out that this process also has an influence on formal institutional arrangements. Economic changes, particularly the economic migrations of China's rural

\footnotetext{
${ }^{517}$ Note: institutional division still exists as evidenced by the value of gaining local urban hukou in areas of high economic development.
} 
citizens were precursors to significant change in the formal institutional arrangements. This formal change increased the propensity of economic migration and further marketization of China's economy. These formal institutional changes reflect efforts to improve local and central government officials' ability to meet one of the fundamental objectives of the huji institution, to accelerate economic development. However, these formal changes also reflect changes in the institutional objective itself. Previously the objective was to utilise huji arrangements to plan and control economic development. This has changed to one of management of market forces to accelerate economic development.

The formal regulations of the huji institution have also been reformed to better meet the objective to maintain social stability. Over the period of study huji management has been significantly reformed by increasing governance of both the temporary and permanent population and by nationalising and modernising huji record collection. Central and local authorities have consistently enforced formal huji regulations to maintain social stability. The influx of rural migrants to urban areas has created new challenges for local public security officials. Prior to the reform era these officials managed a tightly governed, registered and largely static huji population with a large amount of surveillance. Failure to control 'outside the plan' non-huji migration led to temporary residency permits and ever-increasing numbers of non-huji residents in urban areas. Formal regulations concerning the non-huji population have been issued by central and local authorities regularly since the mid-1990s. A web of temporary residency permits, employment permits and temporary identification cards have been employed over the years to bring the non-huji population into the registry and surveillance systems of local authorities. Whilst non-compliance remains, these efforts have greatly increased local public security officials' ability to monitor and manage the 
non-huji population as well as enforce temporary population rates. This has also provided local authorities with the tools to enforce labour regulations (labour contracts, labour conditions, pay) and punish employers exploiting non-registered non-huji employees. Further improvement in this area is required as with cases of huji sales and corruption by local government. Some evidence suggests this is occurring with regulations strictly condemning hukou sales and professionalizing huji management regularly appearing, though, the potential for corruption remains high with such a high value placed on hukou status by Chinese citizens and a lack of independent oversight into huji management by insulated government officials. Huji record collection management has been modernised, nationalised, digitalised and become far more sophisticated and unified. This has provided local officials in urban areas with the institutional tools to greatly improve their management and surveillance of both the huji and non-huji populations residing and working in their hukou zones. These changes reflect efforts to improve local officials' ability to enforce formal huji regulations to achieve the objective to maintain social stability.

The third huji objective identified is to manage and restrict migration. The methods employed as well as the formal regulations have changed considerably to achieve this goal over the reform era. This study has found that a variety of formal huji regulations have been employed to influence population growth and to manage and restrict migration and urbanisation with varying success. Since 1978, China has grown by over 300 million people whilst India has grown by nearly twice that amount. ${ }^{518}$ This is remarkable considering China's population was 400 million greater than India's in 1978. This gap has now closed to nearly 100 million with India most likely to overtake China in the near future. China has successfully slowed the overall population growth through

${ }^{518}$ India 600 million (1978) to 1.2 billion (2007); China nearly 1 billion (1978) to 1.3 billion (2007). 
the family planning policy which relies heavily on huji regulations to be effectual. This has created better conditions for rural to urban migration than would have been possible if the government had not put measures in place to slow population growth. Furthermore, disparity between rural and urban incomes has grown considerably, especially since the 1990s and investment in rural areas remains disproportionately low. Western and central regions remain considerably less developed than the eastern region. Citizens in the east have on average a higher per capita income and create more of China's GDP. These factors create ideal west/central to east and rural to urban push and pull forces for migration and urbanisation. Enforcement of the huji institution has been used to manage and restrict these urbanisation and migration forces in an effort by local government to influence local development trends.

Migration and urbanisation is slowed through an institutional buffer category in the huji system. 'Temporary residency' reduces the desirability of permanent migration and settlement to areas of comparatively high economic development (urban and eastern). ${ }^{519}$ This 'institutional buffer' to residency decreases the desirability of permanent settlement or migration for employment purposes because migrants are assigned a 'second-tier' institutional status in their area of destination. This lowers budgetary pressures on municipal governments and slows the rate of inward migration to developed areas of China. Central authorities have also used the huji system to encourage migrants to migrate to less densely populated areas of China through special inward hukou transfer categories for the non-huji population. For example, the 'selfsupporting grain hukou' for market towns (1984) and the 'small city and town hukou' (1997) included categories for inward hukou transfer for nongmin (steady employment and stable residency) far more liberalised than inward hukou transfer into areas of high

\footnotetext{
${ }^{519}$ As compared to a situation where through migration, employment and accommodation a 'migrant' with citizenship or permanent residence can obtain the same residential status as permanent citizens in urban areas, for example, in New Zealand or the United States.
} 
population density and advanced economic development (for example Beijing). This suggests central authorities use the huji institution to encourage potential migrants to settle in small cities, towns and market towns instead of flooding the large developed centres in the east in centres such as Beijing, Tianjin, Shanghai and Guangzhou. Local municipal governments also have the regulatory authority to entice skilled employees and investors through the introduction of competitive hukou transfer categories. This shows the huji institution has been adapted to governed market conditions to act as a development tool for the state (predominantly local government) to macro-manage and influence migration and urbanisation.

Hukou transfer has however remained controlled at an annual rate of roughly $1.5 \%$ of the size of the existing huji population. Cities in China on average maintain this inward hukou transfer rate but there is considerable variation regionally. Cities will experiment with transfer rates (for example Chongqing) and some cities with large non-huji populations and rapid economic development and advanced marketization of labour markets and industry are found to have a higher rate of inward hukou transfer and more liberalised hukou transfer categories (for example Shenzhen at 6\%). The introduction of competitive inward hukou transfer categories in the late 1990s and early 2000s came after it became apparent to local officials that the 'temporary' residents were residing and settling in urban areas on an increasingly permanent basis. Localisation of huji management has allowed local government officials to use hukou transfer as a way of attracting investment and skilled employees. Whilst hukou transfer is dominated by Chinese elites and local agricultural hukou holders (local rural people granted nongzhuanfei as urbanisation sweeps over their residency) the introduction of competitive hukou transfer categories is a significant trend towards marketization of residency. The Shenzhen blue chop hukou and similar 'intermediary' hukou in other 
cities such as Shanghai represent the forerunners of the competitive hukou transfer categories of the late 1990s and early 2000s. Blue chop hukou are an additional institutional hurdle to full hukou transfer that act as a buffer on migration and settlement much like temporary permits. They grant the holder many of the benefits enjoyed by the local huji population. They are dominated by investor/business and talented employee categories much like hukou transfer and function as a means for local government to attract investment, skills or knowledge in specific technology areas signalled by local government planners as crucial to local development (municipal labour and personnel bureaus). This provided a model for hukou transfer categories introduced in the late 1990 s and early 2000s.

This study also found that Blueprints for Experiments in Small City and Town Huji Management (1997) is a significant institutional adaptation of the huji institution because it increased hukou transfer and nongzhuanfei in low density urban areas. This hukou applied to nongmin engaged in non-agricultural employment or with a steady source of income and fixed domicile for over two years in the experimental zones designated as small city and town huji management reform zones. These zones and the accompanying liberalised hukou transfer system is a form of targeted huji liberalisation to influence urbanisation by guiding the flow of migrants to less densely urbanised areas. Medium and large cities were explicitly excluded. The reforms have been limited for even in these experimental zones quotas have for most remained. In some of the more extreme cases of hukou transfer liberalisation, such as Shijiazhuang City or Zhengzhou City, large growth of the huji population following the introduction of these hukou led to increased local government burdens that led to an abrupt reversal of this policy. These experiments show clearly that hukou transfer remains limited even in targeted areas and that hukou transfer remains open only to relatives of locals, military or cadre 
personnel and to a select group of wealthy investors and businesspeople and China's best and brightest employees or students. In short, hukou transfer policies are used to manage migration in an effort to shape urbanisation.

The huji institution still acts as an intervening variable for migration and urbanisation. Over the period of study the urban population of China grew by 421 million people. ${ }^{520}$ The rural population declined by 63 million. ${ }^{521}$ Urbanisation was found to be more advanced in the east, as were non-agricultural hukou rates, economic development, per capita incomes, the size of the temporary population and rates of hukou transfer. As urbanisation rates in a city grew so too did the percent of non-agricultural hukou holders. The non-agricultural population rate is also higher in cities than counties. These trends were found to be more pronounced in the eastern region. Of the 619 million people in Chinese 'cities' in 2007, 316 million had non-agricultural hukou status (51\%) and 303 million had agricultural hukou status (49\%). Excluding Chongqing, this study found that of this 'city' population, large cities are more likely to have a higher rate of nonagricultural hukou status (for example, Beijing at $80 \%$ ). As the size of the city decreases so too does the likelihood of having non-agricultural hukou status (around $40 \%$ in cities below 2 million in size). As the majority of China's city population live in cities below 2 million in size (453 million people) the problem of urban workers and residents not being accorded non-agricultural hukou status is a large problem in most cities in China. The level of urbanisation is also related to the average wage across the 31 administrative regions in China. As the level of urbanisation grows so too does the average wage. Beijing and Shanghai stand out as highly urbanised areas with well above average wage. Average wage is also related to the rate of non-agricultural hukou. In regions with higher rates of non-agricultural hukou status the average wage is generally higher.

\footnotetext{
${ }^{520} 172$ million (1978) to 593 million (2007).

521790 million (1978) to 727 million (2007).

522 Note: Many Chinese 'cities' also have rural areas making them not strictly 'urban'.
} 
Furthermore, this study has found that there is a significant gap between the rate of urbanisation and the rate of hukou transfer. With 594 million urban residents in 2007 only 431 million people had non-agricultural urban residential hukou. This 'gap' shows the formal rules of the huji institution that categorise China's citizens as agricultural or non-agricultural residents is becoming increasingly non-representative of the type of employment and residency of a large proportion of the Chinese public. The institutional division retains discrimination of rights and benefits as does the local/non-local division. In Beijing there are both 'rural' and 'urban' communities with differing local government services. Local and non-local residents in 'cities' can be agricultural or non-agricultural. Whilst huji reform has in essence targeted these gaps, this study has shown they remain and are in fact increasing. Local/non-local divisions remain stronger than ever. Moves to abolish 'hukou dualism' (agricultural/non-agricultural hukou status) have succeeded in some areas but as of 2007 this division remains in most areas. It is likely agricultural and non-agricultural hukou divisions are being slowly eradicated. Moreover, non-agricultural hukou rates were found to be on average $10 \%$ lower than urbanisation rates. This is consistent over the different rates of urbanisation across the eastern, central and western regions. This suggests that setting local huji population rates at roughly $10 \%$ below the rate of urbanisation is a deliberate policy to try to slow the growth of the permanent urban population by decreasing the likelihood of nongzhuanfei for nongmin or inward hukou transfer and therefore decreasing the appeal of permanent migration to urban areas. Therefore, hukou remains a significant tool utilised by local government officials to try to slow the rate of urbanisation in rapidly developing regions to try to maintain a match between the employment opportunities available in an area and the size of the temporary and huji population through inward hukou transfer. 
Finally, the first case study showed the formal institutional arrangements of the huji institution act as a means for government officials to strengthen the party-state. This is done through the first three objectives, prioritising economic development, maintaining social stability and managing and restricting migration and urbanisation. However, as the case study outlined, the use of the huji institution by local officials to achieve these objectives and to strengthen their overall rule is becoming more and more problematic. This is due to a series of contradictions in the formal government structure of China. On the one hand the Chinese constitution, Chinese law and various international treaties China is signatory to enshrine the principle of equality and freedom of migration in the Chinese government structure. On the other hand, this study and many others have shown that there are very real limits to equality in the Chinese nation-state. Labour migrants holding temporary residency permits are both non-local and for most $(80 \%)$ agricultural hukou holders in their region of non-agricultural employment and residency. Urban nongmin have local huji status but remain agricultural hukou holders. Both groups are urban residents paying urban taxes and contributing to the urban economy. However, both groups fail to have their hukou status reflect their residential and employment conditions and this puts them at a distinct disadvantage compared to the local huji non-agricultural population. This study found that this issue has been prevalent in China since the reform era began but in recent years due to increasing numbers of non-huji nongmingong in urban areas a civic rights movement has begun to emerge. ${ }^{523}$

This emerging civic rights movement has the potential to derail the Chinese development model if central and local governments cannot reform or abolish the huji

\footnotetext{
${ }^{523}$ Pre-reform the division of rural/urban and prevention of migration also contradicted the principle of equality.
} 
institution to safeguard each Chinese citizen's fundamental right to equality. All citizens in China are in legal terms free and equal before the law. Each has the right to compulsory education, to equal employment opportunities, to a variety of civil and political rights and to the right to freedom of migration, settlement and residency. However, this study has shown that each of these rights is secondary to hukou status, that in fact, these rights are at best protected for local, huji and non-agricultural residents in urban areas. The remaining residents in China often have these rights disregarded in their rural areas or when they move out of their permanent hukou location without being allowed to transfer their hukou to the new area they reside and work in. This is leading to labour advocacy and some activism that has the potential to grow into a civic rights movement on a scale unprecedented in China. Similarities here abound with the dualistic system South Africa employed when segregating people based on race and ethnicity prior to the fall of the apartheid government. This leaves the writer wondering if a similar fall of government will occur in China in the future or if the Chinese government of today has the foresight and capacity to reform the discriminatory huji regulations that divide and discriminate against so many of its citizens.

In response, the Chinese government has clearly signalled its intention to incrementally reform the huji institution but even this rhetoric falls well short of what will be necessary to protect the right to equality enshrined in the Chinese constitution and in law. Local and central government openly acknowledge the use of the huji institution as a system to manage and guide China's urbanisation by excluding most rural-to-urban migrants from residency. ${ }^{524}$ There is still secrecy and insulation in huji decision-making and a non-agricultural/local bias still exists in hiring employees, education entrance and

\footnotetext{
${ }^{524}$ Less is mentioned about the economic and security benefits of institutional residency tiers.
} 
various other state affairs. This emerging civic rights movement is not easily reconcilable with formal huji regulations and the objectives of the huji architects. As Fei-ling Wang noted in a 2009 conference at Victoria University of Wellington hosted by the New Zealand Contemporary China Research Centre, the Chinese hukou system remains key to China's institutional reform. ${ }^{525}$

\subsubsection{Major Findings from Cases 2 \& 3: Beijing and Shenzhen}

The second and third case studies were at the local level focusing on huji reform in Beijing and Shenzhen. These case studies identified similarities and differences in huji institutional arrangements over two regions in China at the local government level. The major differences included: a far higher proportion of non-huji residents in Shenzhen than Beijing; a far older and more established huji population in Beijing; a higher rate of inward hukou transfer in Shenzhen (6\% compared to Beijing's 1.5\%); and, earlier hukou transfer reform in Shenzhen than Beijing. These differences, in particular the proportion of the total population that is non-huji, reflect regional economic differences. Shenzhen is a Special Economic Zone and its employers have an insatiable appetite for cheap rural labour to work in the manufacturing and processing zone that fuels the majority of its export-led industries. Beijing in comparison is an established city that requires less cheap rural labour, just enough to provide cheap labour in the service sector and in particular the construction sector. Therefore, local authorities in these regions have created and utilised huji regulations slightly differently to promote economic development because of the differing economic development models in each region. Various similarities were also identified. Firstly, local authorities in both municipalities maintain high conditions on inward hukou transfer that prioritise skills and investment. Secondly, in both municipalities 'temporary' migration is increasingly permanent.

${ }^{525}$ Fei-Ling Wang, "China's Evolving Institutional Exclusion: The Hukou System and Its Transformation," in The Wellington Conference on Contemporary China 2009: Institutional Dynamics and the Modern Transformation of China, ed. Xiaoming Huang (Wellington: The New Zealand Contemporary China Research Centre, 2009). 
Because urbanisation under temporary residency permits is becoming more permanent this represents a significant deviation in actor behaviour from the intention of the formal arrangements to shape the behaviour of actors. More specifically, temporary residency was intended to shape the behaviour of actors to stay for short durations in urban areas for the purpose of contract employment not to remain indefinitely and settle in these regions. The main results from each case study are presented below.

Beijing hukou are highly sought after because Beijing is highly developed with a wide variety of economic opportunities. National ministries and central government are stationed in Beijing. It is an international city with many company offices and it is often the headquarters of China's most successful national companies. The natural growth rate (birth/death) was found to have decreased over the period of study from $9.7 \%$ in 1985 to below $1 \%$ since 1998 . Natural growth of the non-agricultural population was generally above replenishment but natural growth of the agricultural population was generally below replenishment. Most growth in the Beijing huji population was found to come from non-natural growth through inward hukou transfer. Hukou transfer was found to reflect Beijing development interests. Hukou transfer decision-making was found to be predominantly localised and remained insulated. ${ }^{526}$ Highly competitive hukou transfer criteria were found to act as a localised development tool. Transfer categories include relative categories and military, cadre and government categories as well as those applicants applying through a Beijing work unit. Whilst there are 18 categories of inward hukou transfer, the majority of Beijing's 'temporary' migrants (non-huji residents) are excluded from hukou transfer because the conditions on inward hukou transfer are extremely hard to meet, usually requiring connections, accommodation, investment or highly valued employment skills. There are now 7

\footnotetext{
${ }^{526}$ Including: Beijing Personnel Bureau; Beijing Labour and Social Security Bureau; Beijing Public Security Bureau; Ministry of Labour and Social Security; Ministry of Personnel.
} 
categories of inward hukou transfer into Beijing based on what an applicant can offer the city. These focus on investment, business enterprises, skills and education and sporting or cultural talent/fame. There is also some variation within the different regions of Beijing. For example, to transfer hukou into Dongcheng using the investor category, an applicant needs roughly twice the level of capital, paid tax and employee numbers that an applicant for inward hukou transfer to Changpin requires. Therefore, local authorities have an important regulatory tool to influence the socio-economic development of Beijing through the selection of residents deemed in the interests of development. Because Beijing hukou are so valuable, this highly competitive system of huji transfer management increases Beijing local government officials' ability to ensure Beijing remains a leading city in China. From this perspective, the huji system has been successfully modernised through the liberalisation of transfer categories to meet these development goals.

Formal huji regulations for Beijing's non-huji population have also changed significantly over the period of study. A series of regulations since 1985 have formalised the temporary residency permit system in response to increased non-huji population numbers. This represents attempts by local authorities to manage this population and regain governance of the entire Beijing population. Local authorities stress the need for 'orderly population flows' that are linked to the creation of employment opportunities. The temporary residency category has significant benefits compared to non-compliance. Non-huji residents with temporary residency permits can gain a legal work permit, apply for insurance and pension schemes and have a degree of legal protection especially regarding labour rights and payments. These policies have provided officials with the institutional tools to re-gain governance over the increasingly mobile non-huji population. Overall, growth in the Beijing huji population has been 
incremental and steady whilst non-huji population growth has been sporadic. This shows the importance of the 'institutional buffer' that temporary residency provides. Whilst the overall growth has been sporadic and extreme at times, these challenges have been in many ways kept from influencing governance because temporary residents are not entitled to most government services.

Non-huji residents were found to be disproportionately represented in service industries, construction and production. The huji population by comparison are far more likely than the non-huji population to be employed as professionals, state and party personnel or clerks. Their employment is far more evenly spread over the variety of employment opportunities in Beijing. The huji population also earn far more on average and consume far more than the non-huji population. Non-agricultural hukou holders in the Beijing non-huji population are significantly better placed economically than their agricultural hukou holder brethren. This shows the continual significance of both local huji status and non-agricultural hukou status. Growth in employment opportunity in Beijing has occurred in urban industries. Agricultural employee rates have remained steady. As the population has increased this shows evidence of the Lewis Transition in effect. Local government has recently recognised the important contribution the nonhuji population make to Beijing's economy and some effort has been made to decrease the institutional discrimination they are subject to by increasing the local government services provided to non-huji residents with temporary residency permits. ${ }^{527}$

Since 1985, the increasing number of non-huji residents in Beijing has preceded institutional reforms of the formal huji arrangements. This began with the introduction of temporary residency permits and was followed by employment permits, family

\footnotetext{
${ }^{527}$ For example, through the provision of compulsory education to migrant children and through the availability of greater social security.
} 
planning certificates and employment cards for outward migration (required by migrants from their sending area). The Beijing huji management system has been fully integrated into the national system and unified with the other provinces, especially the sending provinces. This has greatly increased the ability of Beijing Municipal authorities to govern the floating population and to better match the size of the temporary resident population with the economic opportunities available in Beijing for predominantly unskilled rural migrants. However, as in other parts of China an informal practice that diverts significantly from the formal huji regulations has developed. This emergent practice is seen in the increasing permanence of 'temporary' migrants who settle in Beijing. The urban bureaucracy has adapted many of the discriminatory policies in response to this, including, employment and housing, education, workplace safety and labour rights and provision of social security and insurance. It is however still far better to be a Beijing huji resident for those migrants wanting permanently to migrate and settle in Beijing. Hukou transfer is still strictly controlled and kept 'artificially low' by local government and is becoming an increasingly contentious and important area of debate. Hukou transfer is still predominantly off-limits to the vast majority of the nonhuji population in Beijing. The competitive hukou transfer categories apply only to a select few candidates that can meet the high conditions set out. Therefore, there is now emerging not just a call from the non-huji population for improved rights as Beijing non-huji 'temporary' residents but increasingly as residents deserving of local huji and non-agricultural residency status the same as the existing huji population and their offspring.

Shenzhen in comparison exhibited high rates of both natural growth of the huji population and high rates of inward hukou transfer, though this growth was steady over the entire reform era. Population planning targets were found to have an inward hukou 
transfer rate over four times as high as Beijing's for 2008. This suggests that cities with small huji populations and large non-huji populations are more likely to have a higher rate of inward hukou transfer than established cities with a large existing huji population and a lower proportion of non-huji residents. Shenzhen, as a young and comparatively 'under-populated' city, also has a lot more opportunity for inward hukou transfer. As one of China's SEZs, employment opportunities and the need to attract skilled employees through hukou transfer is a lot higher than in Beijing. Conservative estimates of the non-huji population also show that Shenzhen's non-huji population is proportionately high. Non-huji migrants grew to one million by 1991 and to nearly 6 million by the year 2000 . Other estimates place the non-huji population at 12 million in 2005. Baoan and Longgang districts accounted for the majority of the non-huji population.

These factors have led to a different process of emerging huji regulations in Shenzhen. As a SEZ, the Shenzhen municipal government has had more freedom to experiment with market-orientated reforms and has benefited from high rates of FDI and national investment. As an SEZ with a small huji population, Shenzhen industry has required a large non-huji population to labour in these industries. At the beginning of the $1980 \mathrm{~s}$ Shenzhen's local government became one of the first local governments to face the challenge of adapting the huji institution to the influx of large numbers of unskilled labour without local huji status. This led to early reforms in the areas of health insurance and social security, education for migrant children and employment rights and labour standards, though many issues still remain. Reforms such as these removed some institutional exclusion between the huji and non-huji populations. But perhaps the most significant reforms that came early in Shenzhen have been in the area of temporary residency permits, blue chop hukou and hukou transfer. The decision-making bodies 
responsible for these reforms include the Shenzhen Public Security Bureau, the Shenzhen Personnel Bureau and the Shenzhen Labour and Social Security Bureau. These bureaus were responsible for introducing some of the earliest competitive hukou transfer (and blue chop) categories in China. These focussed on employment, home ownership and business investment and set the model for the rest of China to follow.

In Shenzhen, as opposed to most other cities, there are three tiers of residency: temporary residency, blue chop hukou, and huji residency. The addition of an extra tier can be seen as a further buffer on pressures on local government to increase hukou transfer rates even further. Hukou transfer policies have prioritised transfers deemed by local authorities to be in the interests of economic development of the city. Temporary residency permits have provided some management of the unskilled labour force used in the large factories of the SEZ. As in other parts of China what was intended as temporary residency has in fact become more permanent. This has increasingly put pressure on local officials to increase transfer rates. Though, as in other parts of China these changes have focused primarily on improving temporary resident permit conditions (primarily labour conditions) and on attracting skilled employees and investors at the top end of the labour market through competitive inward hukou transfer and blue chop hukou categories. Shenzhen's population management is unique in China because there is an extremely high proportion of non-huji residents; it has an above average rate of inward hukou transfer; there was early liberalisation of employment and residency for the non-huji population; there was early liberalisation of non-huji exclusion; there was early liberalisation of hukou transfer categories to incorporate attracting employment skills and investment; and there has been the addition of an intermediary residence category in the form of the Shenzhen blue chop hukou. These moves are mainly due to Shenzhen's role as an export manufacture and processing zone 
which requires expert managers and technicians and investors as well as a large army of generally low-skilled workers.

Overall, reform has been incremental in both Beijing and Shenzhen and huji management still has the power to intervene in the labour market and shape the development of these cities. Localisation of huji decision-making has allowed greater diversity in huji policy as local governments use enforcement of huji regulations to promote local development under varying socio-economic conditions. Shenzhen has a workforce predominantly made up of non-huji residents. Beijing has a workforce predominantly made of huji residents. Growth of the non-huji population has been an important feature of the economic development of Beijing whereas in Shenzhen it has been critical to its development. Liberalisation of non-huji residency and employment as well as hukou transfer has been more pronounced in Shenzhen. This suggests a greater path dependency in areas where the institution has been used as a governing tool for longer periods of time and there is a proportionately large huji population with established interests. Employment opportunities in Shenzhen by comparison have led to greater liberalisation of temporary residency and hukou transfer to attract the needed labour force for development of the SEZ. Huji reform in Beijing and Shenzhen as well as reform of the nationalised huji institution has come about through a variety of factors. The following section presents the results from all three cases regarding the process of formal institutional change in China's huji system.

\subsubsection{Continuity and Change: Major Findings}

Explaining continuity and change in the huji system can be confounded by the complexities of its goals and functions as well as the complexities of huji policy and implementation foreign to most non-PRC citizens. The national level case study clarified how local and central authorities have used the formal huji regulations to 
accelerate economic development, maintain social stability, restrict and manage migration and urbanisation and strengthen the party-state. Continuity is shown in the behaviour of central and local officials (both enforcers and architects) who have maintained the huji institution as a governance tool that provides them with the power to influence the behaviour of actors (all Chinese citizens). Informal institutional practices have developed diverging from the formal regulations but this does not negate the fact these local authorities still utilise the formal huji regulations to influence the behaviour of China's citizens to meet these traditional institutional objectives. Enforcement has maintained strict controls on hukou transfer rates and a significant degree of institutional exclusion of the non-huji population. Whilst the new institutional category of nongmingong is increasingly permanent at destination, these Chinese citizens are not accorded the same institutional status with accompanying benefits as local huji residents. This decreases the desirability of long-term/permanent migration to the city, increases the likelihood of return migration and places a buffer on pressures for greater inward hukou transfer, in effect slowing migration. Whilst central and local authorities no longer attempt to strictly control the movement of Chinese citizens (except in special circumstances such as the 2008 Beijing Olympics) they still maintain a large degree of influence over migration and settlement and continue to shape the migratory and settlement behaviour of actors through strict control of hukou transfer and continual huji/non-huji institutional exclusion. Settling in Beijing as a local huji resident (hukou transfer) and settling there as a non-huji temporary migrant (with or without temporary residency) are very different circumstances. This suggests the rate of urbanisation is being slowed by local authority control of hukou transfer and the creation of the temporary residency category and that Chinese authorities use these unique institutional arrangements to better align temporary and permanent migration and urbanisation with local levels of economic development. 
Therefore, the huji institution remains an important regulatory tool for local authorities. Whilst China's economy has liberalised considerably over the period of study the huji institution still acts as an intervening variable on socio-economic behaviour. It remains an indispensable regulatory tool for local government authorities. This confirms the importance of institutional studies for research into China's socio-economic transition. There remains a strong degree of continuity in the objectives local authorities use the huji system to try to achieve. This continuity remains because by and large huji regulations and transfer decisions are made by insulated local body officials of the municipal government in their governing interests. ${ }^{528}$ Changes have however occurred and there is an increasing trend towards a more marketized and competitive hukou transfer decision-making process. The major change in the decision-making process has been the inclusion of market interests and the modern value of efficiency to the governed market economic development models. The modern values of equality, democracy and representation have been introduced to some extent but overall this has lagged far behind the introduction of economic rationales focusing on efficiency, competitiveness and development.

The huji institution has liberalised in two key areas. The first and most significant change has been the liberalisation of controls on non-huji employment and residence in urban areas. The second is the liberalisation of inward hukou transfer regulations through the introduction of competitive hukou transfer categories. Both changes occurred in conjunction with the growth of the secondary and tertiary sectors in urban areas, particularly on the east coast, and the construction of new economic rationales for the development and modernisation of China. The movement of China's rural

${ }^{528}$ These decision-makers are local officials in the labour bureau, personnel bureau and public security bureau. There remains some central government oversight from the Ministry of Labour, Ministry of Personnel and most importantly, the Ministry of Public Security. 
workforce into employment in urban zones began prior to the formal directives allowing this practice. Inward hukou transfer for investors and skilled employers took place through illegal hukou sales prior to the directives at the central and local level setting out conditions for competitive hukou transfer categories. Without the need from business for access to China's rural and non-local workforce it is unlikely temporary residency permits or competitive hukou transfer categories would have been introduced. The liberalisation of huji management has been to the benefit of employers and local government in urban areas and this is the primary driving force behind these moves. Local government decisions are now highly influenced by the requirements of local enterprises when setting huji policy where once government decision-making was almost exclusively insulated from non-government forces. ${ }^{529}$ This is true at the bottom end of the labour market where local authorities issue temporary permits to migrant workers employed in local enterprises and at the very top end of the labour market where local enterprises and local government attract talented employees through the enticement of inward hukou transfer. However, the interests of a vast number of institutional actors have not been met by these formal institutional changes and this has led to increasing divergence in formal institutional arrangements and informal institutional practices.

As with any formal institution, there is a gap between the formal rules of the huji institution and the practice of the actors bound by the formal regulations. This gap has been exemplified in two main areas over the period of study. First, the gap between regulations preventing rural to urban migration and the increasing prevalence of rural to

\footnotetext{
${ }^{529}$ Prior to the reform era command economy conditions meant the Ministry of Personnel, the Ministry of Labour and the Ministry of Agriculture controlled and planned China's economy. Huji policy and enforcement served the directives of these ministries. Post-1978 these ministries, and to some extent the Ministry of Public Security, became increasingly responsive to the requirements of non-government economic interests whilst setting huji policy. Moreover, a vast number of SOEs in China became increasingly 'marketized' and now more closely resemble private companies.
} 
urban labour migrations appeared early in the period of study. Pre-1978 the huji institution was enforced by the 1958 Hukou Registration Regulation. This regulation did not have formal rules for non-huji residents from rural areas with agricultural hukou to reside in urban areas employed in non-agricultural work. As this trend began in the late 1970 s and early 1980 s, the gap between the formal rules of the institution and the informal practice grew. An informal practice developed to accommodate the interests of employers in urban areas and the rural population keen to earn more labouring in the city. This informal practice occurred prior to the 1985 directive that formalised the temporary residency of non-huji residents in urban areas for temporary contract employment. This shows that prior to significant formal institutional change an informal practice diverging from the formal rules appeared. This suggests formal institutional arrangements not only shape the behaviour of actors through enforcement but that the behaviour of actors can also shape formal institutional arrangements.

Second, the trend towards increasing permanent rural to urban migration without permanent hukou transfer has appeared representing an informal practice that diverges significantly from the formal rules outlining temporary residency of the non-huji population for contract employment and temporary residency in urban areas. As the temporary population have become increasingly permanent, the gap between the formal rules outlining temporary residency has grown. This has preceded some liberalisation of inward hukou transfer and a lowering of institutional exclusion of non-huji/temporary residents. This suggests the informal practice of permanent rural to urban migration by 'temporary residents' also shapes the formal institutional arrangements. This will likely continue to lead to further decreases in discriminatory policies towards non-huji residents and further liberalisation of hukou transfer. There will likely be a gradual phasing out of agricultural and non-agricultural hukou status making nongzhuanfei 
irrelevant, a strengthening or adaptation of the temporary residency permit system and a lessening of discriminatory huji/non-huji exclusion, and finally, further development of residency schemes promoting inward hukou transfer of skilled employees and investors. ${ }^{530}$ This seemingly contradictory combination of continuity and change can be explained through an analysis of the institutional objectives and the changing socioeconomic environment.

The huji institution is employed by local and central officials as a development tool. In the 1960s and 1970s the formal rules of the huji institution were central to the division of rural and urban populations through the creation of agricultural and non-agricultural hukou categories. The agricultural population, accounting for around $80 \%$ of the entire population, was made responsible for food provision to the urban population whilst the urban population was allocated employment by central planners and made responsible for China's socialist modernization. This 'heavy handed' approach to population mobility and employment by central planners has diminished over the reform era. The huji institution is now used by local officials as a development tool to manage and slow the rate of urbanisation and to influence the migratory and settlement behaviour of Chinese citizens but not to strictly control and plan these things as it once did. This is done by placing limits on both the growth of the huji population and the growth of the non-huji/'temporary' population. This effectively creates a two-tiered institutional division decreasing the attractiveness of permanent urbanisation and migration to urban areas of high socio-economic development for those who fail to either gain temporary residency (second-tier) or hukou transfer (first-tier). Obtaining temporary residency requires accommodation, employment or connections in the city. Obtaining inward hukou transfer requires a successful business, talent or a large amount of capital to

\footnotetext{
${ }^{530}$ There is very little evidence to suggest that policymakers intend to abolish the huji non-huji division.
} 
invest in the city. Migrants that fail to obtain temporary residency permits find themselves living outside the law, unable to obtain legal employment and more susceptible to abuse and exploitation. Migrants that obtain temporary residency can apply for employment permits, workplace insurance schemes and can legally sign employment contracts. Labour rights are more likely to be upheld for these temporary labourers than unregistered 'floaters'.

The first institutional tier applies only to a select group of the non-huji population. Inward hukou transfer has incorporated competitive transfer categories but the conditions in these categories remain extremely high. Moreover, municipal authorities set planning transfer rates to slow the 'non-natural' growth of the local huji population. There is considerable variation in both second-tier and first-tier population rates over varying regions in China with differing economic conditions. This is shown in the comparison of Beijing and Shenzhen. In places like Shenzhen, there is a further intermediary institutional tier for the non-huji population (between temporary non-huji residency and local huji). The blue chop hukou is a hukou status in Shenzhen one step short of full huji status. These residency tiers act as breaks on what local officials predict could be blind rural to urban migration and a swamping of urban areas leading to social instability, greater economic exploitation and lowered socio-economic development of these regions. Therefore, local government efforts to manage the development of China's urban areas through managed urbanisation are an important feature of the Chinese development model.

Officials and academics in China and abroad have been promoting modernisation since the late Qing era but only since the late 1990s has China's modernist project achieved 
astounding success. ${ }^{531}$ This study has shown that one of the keys to this recent success has been the transfer of rural agricultural hukou labourers to non-agricultural employment in urban areas. This study has also shown local government authorities have managed that transfer in line with their local development goals. This has required liberalisation of formal huji regulations guiding residency and settlement. The introduction of temporary residency permits allowed the mass movement of rural workers into the secondary and tertiary industries in urban areas. The introduction of competitive inward hukou transfer categories liberalised hukou transfer for China's most successful people providing further market rationales. It is tempting to conclude the successes of the last few decades of reform are primarily due to the successful management of the urbanisation of the Chinese workforce, and, with a large underemployed rural population remaining, it is tempting to predict China's rapid economic growth could if other factors remain favourable continue for another 20 years if managed well. ${ }^{532}$ As the non-huji population grows, hukou transfer will most likely continue to be liberalised and temporary residency may gradually be phased out. ${ }^{533}$ The institutional challenge for the architects and enforcers of the huji institution will be managing the rate of liberalisation and giving enough freedom to ensure economic development is not stifled by government intervention.

This study has shown that socio-economic change leads to divergent actor behaviour evidenced in the informal institutional practices. Moreover, if the gap between the formal rules of the huji institution and the informal practices of the actors and enforcers grows enough then this is usually followed by formal institutional change as the institutional architects reformulate the formal institutional arrangements to better meet

\footnotetext{
${ }^{531}$ This is not to negate the importance of the earlier development later development grew from.

532 Such factors include, export markets, the exchange rate, resource security, political stability and so on.

${ }^{533}$ Recent news articles (2010) suggest this has already begun with moves to replace 'temporary residency' with 'residency' permits.
} 
their institutional objectives. This is evidenced by catering to the needs of employers for access to the rural labour pool by the introduction of temporary residency cards and by catering to the needs of China's growing pool of well-off people through the introduction of competitive hukou transfer categories. Central and local authorities have successfully managed the growth of these market forces over the reform era by liberalising two key areas of huji management, temporary residency and inward hukou transfer. The reforms reflect a strong degree of influence from local employers and the local huji population. Institutional 'tiers' influence and shape behaviour whilst allowing market forces to operate where once they were obstructed and controlled. The findings of this research point not only to a particular case of institutional change in a Chinese institution but can also be generalised. A model of institutional change can therefore be devised from these observations.

\subsection{A Model of Institutional Change in China's Huji System}

Historical institutional analysis of formal institutional change interprets linear events by comparing later events with prior events to distinguish what and how formal institutional change occurs. Whilst formal institutional arrangements are for most static or changing in clear ways at set times, informal institutional practices (institutional enforcement and actor behaviour) are fluid and constantly in flux. The distinction between formal institutional arrangements and informal institutional practices is central to understanding the process of formal institutional change. Change predominantly originates in this formal/informal 'gap'. Combinations of socio-economic factors change actor interpretation of static formal institutional arrangements leading to actor behaviour that differs significantly from the intentions of the arrangements. If institutional arrangements remain static whilst the socio-economic environment changes,

a corresponding change in actor behaviour and enforcement in practice will occur. Actors will be shaped differently by the same formal institutional arrangements and 
intended enforcement if the socio-economic conditions that play such an important role in their interpretation of the formal regulations differ. The emergent behaviour will differ from previous behaviour due to these new socio-economic conditions. This shows the importance of the institutional 'environment' and the emerging informal institutional practices to the process of formal institutional change. Whilst formal institutional arrangements go unchanged, informal arrangements can differ significantly due to external factors. For example, prior to the reform era there were few employment opportunities for rural migrants in urban areas. This changed in the early 1980 s as rural migrants were increasingly employed in low-end urban industries. Whilst the formal institutional arrangements had not changed, actor interpretation of the formal regulations in the new socio-economic environment led to behaviour that differed from when there were few employment opportunities for them. This shows the importance of exogenous factors to the way enforcement of an institution shapes the behaviour of actors. Moreover, when the informal institutional practice diverges from the intentions of enforcement of the formal institutional regulations to such a degree that it no longer corresponds to the behaviour intended by the architects of the formal institutional arrangements, these architects are likely to change the formal institutional arrangements and their enforcement of them so they better meet their institutional objectives. ${ }^{534}$

A second type of change identified in this study occurs when an institutional objective changes. This can occur both from exogenous factors, resulting in changed actor behaviour (as above), or through endogenous factors such as a changing institutional culture. When institutional objectives change, architects change the formal regulations and their enforcement so they better shape the behaviour of the actors to meet the new

\footnotetext{
${ }^{534}$ Failure to change the formal institutional arrangements and their enforcement when faced with changed actor behaviour that no longer meets institutional objectives endangers the efficacy of the institution. Any institution that no longer serves its purpose is redundant and of little use (or harmful) to the institutional architects and enforcers.
} 
or adapted objectives. Distinguishing whether this type of change is exogenous (originating outside of the institution) or endogenous (originating from within the institution) is in no way clear. For example, the introduction of competitive hukou transfer categories (a significant change to the formal huji arrangements) can be attributed to both exogenous and endogenous factors. Exogenously, the growth of the market economy led to an increased demand from employers for inward migration and settlement with hukou transfer to attract talented employees to their urban industries. These demands influenced policy-making decisions. Endogenously, since Deng Xiaoping the culture of the party-state has increasingly prioritised marketization of most aspects of the Chinese governance model and encouraged local officials to introduce new methods of promoting economic development in their region. Therefore, whilst the distinction between endogenous and exogenous factors in the study of institutional change highlights the difference between change originating from within or without the institutional setting, this study has shown that more often than not, both endogenous and exogenous factors are involved in the long and often complicated process of change to formal institutional arrangements, especially if these changes involve deep reform of the actual institutional objectives.

Figure 76 presents a model of institutional change that sets out the dynamic process of formal institutional change. Enforcement and actor behaviour represent the informal institutional practice. Endogenous and exogenous factors are shown to have significant influence on and be affected by the interpretation and behaviour of the actors, enforcers and architects of the institution. The following three parts of this section explain the interdependent relationships between these actors focusing on exogenous and endogenous factors. The final part of the section re-states the process of formal institutional change. 


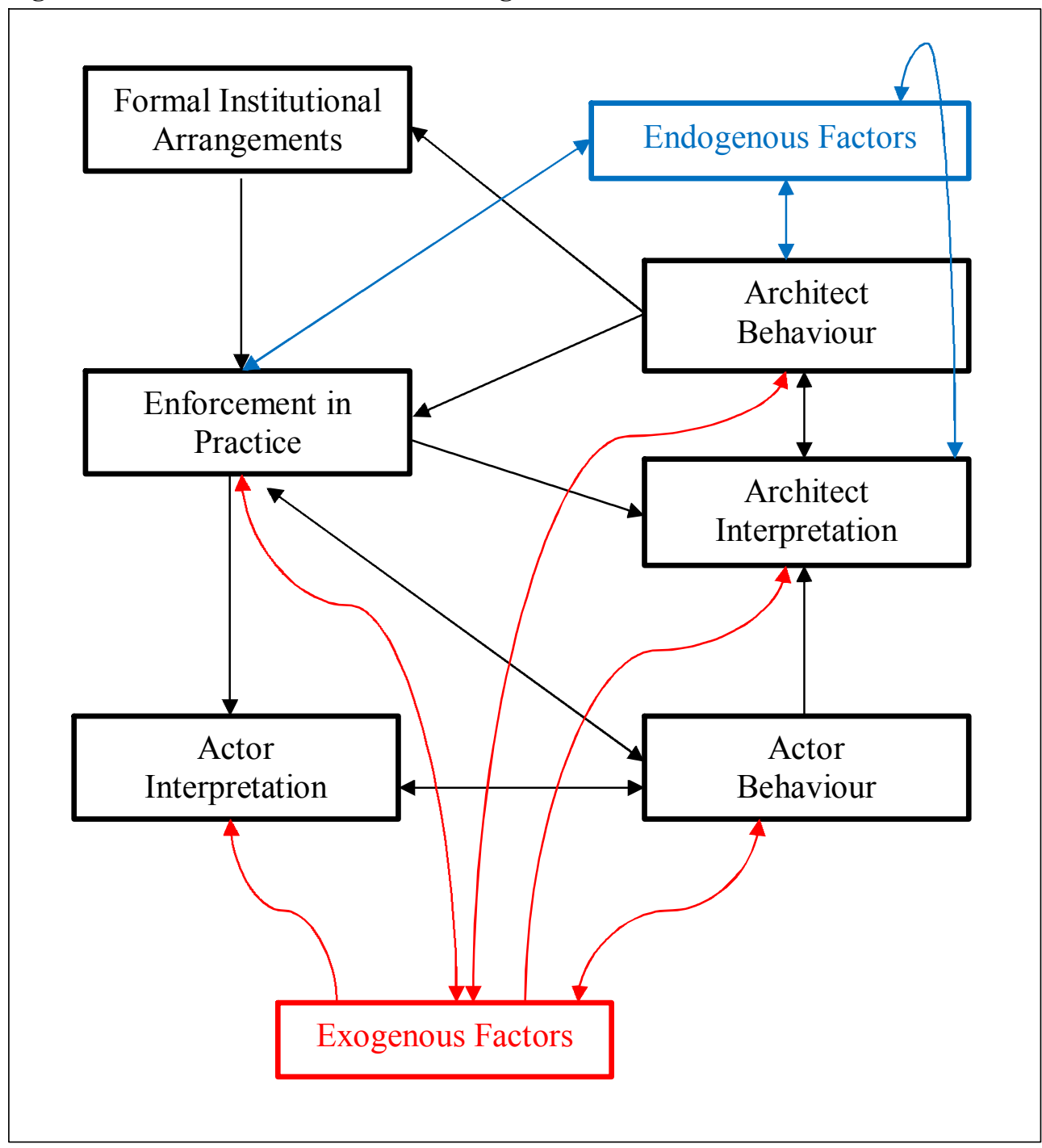

\subsubsection{Formal Institutional Arrangements \& Enforcement in Practice}

The formal institutional arrangements of the huji institution are defined by a collection of rules, regulations, laws, policies and plans. Examples include the $1958 \mathrm{Hukou}$ Registration Regulations, the 1985 Interim Provisions for Temporary Residency, the Shenzhen blue chop hukou introduced in 1996 or Beijing inward hukou transfer categories and rates. The formal institutional arrangements of the huji institution can only be modified by central and local government officials. These 'architects' are the only people with the power to directly modify the formal institutional arrangements. However, as figure 76 shows, there are a number of important factors that influence 
architect behaviour and the construction of the formal institutional arrangements. The most significant of these include a variety of factors internal and external to the institutional setting (exogenous and endogenous factors), the behaviour of the actors (the litmus test for institutional efficacy) and the enforcement in practice of the formal institutional arrangements.

Formal institutional arrangements are enforced by local government. The most important enforcers include public security officers (especially huji police) and local public security, personnel, labour and social security bureau officers. Enforcement of the formal huji regulations by this group of people shapes the behaviour of the actors. ${ }^{535}$ For example, a non-huji migrant resident who fails to apply for temporary residency cannot obtain an employment certificate and work legally. This has obvious and significant consequences for the actor. Enforcement will also have a significant impact on an actor's interpretation of the institution. For example, the ability of urban enforcers of the huji institution to prevent most non-sanctioned rural to urban migration in the 1970s through exclusion from the urban rationing regime (food allocation, social services and employment), was an important consideration for anyone contemplating moving outside of their permanent hukou location without government sanctioned hukou transfer. In the early $1980 \mathrm{~s}$, the increasing inability of urban enforcers to prevent outside the plan rural to urban migration represented a significant change in enforcement in practice. This changed actor interpretation of enforcement of the huji institution. Both actors and architects interpret the functioning of the huji institution not through the formal regulations themselves but through enforcement of these regulations in practice and ultimately through their experience of the behaviour of the institutional

${ }^{535}$ This is the fundamental institutionalist assumption, that institutions shape the behaviour of actors. 
actors. ${ }^{536}$ This highlights the gap between what the formal written regulations of an institution state and how the formal regulations are enforced. This study has shown that such gaps, if large enough, are often followed by changes in the formal institutional arrangements. Architects make these changes to meet new institutional objectives or to better meet existing objectives. The introduction of temporary permits after an influx of rural migration for employment in the $1980 \mathrm{~s}$ is an example of this process.

Whilst formal institutional arrangements are intended to guide enforcement there are other factors contributing to hukou enforcement in practice. The behaviour of the institutional actors is obviously influenced by enforcement but enforcement is also influenced by the behaviour of institutional actors. This is one of the reasons why there is often a gap between the formal written regulations and enforcement in practice. For example, the growing influx of non-huji rural migrants employed and residing in urban areas in the 1980s due to growing low-end employment opportunities meant it became increasingly difficult for local authorities to enforce the 1958 regulations by returning these migrants to their registered hukou location, (especially because local industries gained significant benefits from employing migrant contract labourers). Additionally, the architects of the formal institutional arrangements also directly influence enforcement. This is a more direct route than influencing enforcement through changes to the formal regulations. The chance of this is high because the same people who are responsible for determining the formal regulations of the huji system are also responsible for managing the enforcers. They belong to the same overarching institutions, the CPC and the Chinese government. Both endogenous and exogenous factors can also influence enforcement. Exogenous factors include the development of surveillance technology or the size of the local tax revenue due to private economic

\footnotetext{
${ }^{536}$ Architects are concerned with the ability of enforcement of the formal institutional arrangements to shape the behaviour of actors in a manner intended to meet the institutional objectives. Actors are concerned with the likely consequences of their intended behaviour.
} 
activity. Endogenous factors include the culture, habits and learned behaviour of the institutional enforcers. The 'culture of enforcement' can change over time. An example of this is the sale of illegal hukou transfers in many municipalities in the 1980s and 1990s and perhaps still today. Whilst this is an extreme example, it again illustrates the point that there will always be a gap between the formal arrangements of any institution and the actual enforcement of those formal arrangements. If the gap grows large enough this drives formal institutional change.

\subsubsection{Actor Interpretation \& Behaviour}

Actor interpretation is the cognitive precursor to actor behaviour. Actors will interpret an institution on the basis of their knowledge of how it is enforced and past experiences of collective and individual actor behaviour. This interpretation is based on partial information and influenced by a variety of factors including intelligence, education, culture, national discourses, and so on. Institutions shape the behaviour of actors by influencing their decisions through enforcement. A constant feedback loop informs actors of the consequences or benefits of certain types of behaviour. Learned behaviour develops through the interaction of enforcement of the institution and the individual and collective behaviour of the institutional actors. Institutional actors have a limited understanding of how local government officials enforce the huji institution in varying areas through word of mouth and general knowledge and one's own experience. Enforcement has, of course, very real consequences for actors and through learned collective and individual experience actors learn the likely outcome of their intended behaviour. For example, rural to urban migration by nongmin means they will almost definitely be institutionally excluded from local huji residency in the area these non-huji permanent residents live and work. In the 1970s, actor interpretation of enforcement led to very little outside the plan migration due to the consequences of enforcement in the planned economic setting. Whilst there has been only minimal change to formal 
institutional arrangements of hukou transfer for nongmin, a phenomenal number of rural migrants have moved to the cities since the period of study began. This is because under a similar formal institutional setting, non-sanctioned migration is viewed differently and is more achievable in the new socio-economic environment. This shows the behaviour of institutional actors is not only determined by the enforcement of the formal institutional arrangements. The same or similar formal institutional arrangements can in fact result in divergent actor behaviour due to varying 'environmental' conditions. ${ }^{537}$

The interpretation of both individual and collective learned actor behaviour and institutional enforcement is also mediated by the objectives, beliefs and understandings of the actors themselves. Actors interpret enforcement of institutional arrangements from the perspective of their own individual and collective interests. These interests are informed by a multitude of factors external to the institution. These factors can significantly change the way an actor interprets the institution and forms their plan of action even when there has been no change in the formal regulations and little change in the enforcement of the institutional arrangements. This study has highlighted the increasing availability of low-end employment in China's rapidly expanding secondary and tertiary sectors (as well as limited high-end employment opportunities for talented migrants) as important exogenous factors that have significantly change the way actors interpret enforcement of the institutional arrangements and ultimately changed the way actors behave. Therefore, institutions shape the behaviour of actors but the way behaviour is shaped is dependent on how the institutional actors interpret enforcement of the institution. Interpretation of enforcement is mediated by the individual and collective aspirations of the actors which are strongly influenced by a variety of factors external to the institutional arrangements and enforcement of them. Examples include

\footnotetext{
${ }^{537}$ This has obvious implications for both historical institutionalist studies and institutionalist studies comparing the outcome of similar institutional arrangements in various comparative settings.
} 
increasing employment opportunities in urban areas or a changing national discourse that prioritises urban development and relegates agricultural traditional ways of living to an inferior status.

The behaviour of actors is the definitive test of the efficacy of any institution because institutional architects establish and enforce formal regulations precisely to shape the behaviour of actors to meet their institutional objectives. This is how local and central government have the power to influence (but no longer control) the socio-economic behaviour of their citizens. Enforcement has a significant influence on actor interpretation and actor behaviour. Actor interpretation informs behaviour and that behaviour is again mediated by the limits, consequences or divisions placed on that behaviour by the enforcers of the institution. For example, an actor may interpret enforcement of huji regulations as no longer an impediment to their migration to an urban centre in China. This may lead to them attempting to migrate to the city but the local labour bureau stepping in to place them on a work programme in another part of China. Or, if employment is not found and the migrant fails to obtain even temporary residency they may find the formal institutional arrangements that exclude them form legal residence as too uninviting and return to their permanent hukou location. Both an actor's interpretation of events and the actual enforcement of institutional regulations will shape the behaviour of actors.

A similar limitation on actor behaviour comes in the form of a variety of external factors. The enforcement of the formal regulations and a variety of external factors play important roles in how the actor interprets their place in the institutional setting and what they interpret as the best course of action for them. For example, an actor may interpret current huji regulations as no longer being an impediment to survival in an 
urban area because of the availability of employment and the growth of the market economy that allows them to rent accommodation and buy life necessities if they have the money. This may lead them to migrate to an urban centre. When they arrive they may not be able to find suitable employment and are forced to return to their family plot in order to survive. Therefore, interpretation of the formal institutional arrangements takes place within a particular socio-economic setting that leads to actor behaviour based on their decision whether migration is deemed in their best interests. This actor behaviour is again subject to the consequences of enforcement of the formal institutional arrangements and the actual socio-economic conditions they encounter.

Clearly then, institutions shape the behaviour of actors but this is mediated by a variety of 'environmental' factors. Moreover, the behaviour of actors not only culminates in an informal institutional practice but (and this is a significant finding of this research), this practice has the potential to shape the formal institutional arrangements. In short, these relationships are dynamic. If enforcement of formal regulations produces actor behaviour that diverges from the objectives of the institutional architects it is likely enforcement, the formal regulations and/or the actual institutional objectives will be changed by the institutional architects. This shows the significance of actor behaviour to institutional change through its importance to both enforcement and architect interpretation of the efficacy of the institution to meet their institutional objectives. In the case of the huji institution, actor behaviour has significantly changed both enforcement and architect interpretation of the efficacy of the institutional arrangements. Changing interpretation by institutional architects due to changing actor behaviour leads to changing architect behaviour which leads to changing formal regulations. These changing formal regulations then shape the behaviour of actors in the changing socio- 
economic environment. Architects then re-assess the efficacy of the formal institutional process. This is a constant but imperfect process.

Actor behaviour also influences actor interpretation of the institutional setting and a variety of variables external to the institution but often closely linked to institutional objectives. Actor behaviour that is perceived as rewarding will have an important influence on individual and collective actor interpretation of the institution. For example, rural to urban migration from the perspective of many nongmin in rural areas is generally seen to bring material benefit. This increases the likelihood that other nongmin will also migrate to urban areas in search of employment and creates positive feedback loop increasing the likelihood of further migration. Secondly, actor behaviour influences the institutional environment. For example, as socio-economic factors influence migration, migration in turn influences society and the economy. Increased non-huji residency has led to an economic boom in the eastern region that further increases the desirability of rural to urban migration and western to eastern migration. These migrations have also created many local government challenges such as increased crime and the difficulties of managing a non-huji population. All these factors contribute to how the architects of the formal regulations interpret the efficacy of the institution to meet their institutional objectives.

\subsubsection{Architect Interpretation \& Behaviour}

Architect interpretation is the cognitive precursor to architect behaviour and should therefore not be understated. Architect behaviour results directly in the construction of both the formal regulations and the institutional goals. Architect interpretation plays an important role in institutional change because institutional architects have the only direct link to the formal regulations and the ability to change them through their behaviour. In the case of the huji institution the same local and central government 
authorities are responsible for creating and overseeing enforcement of the institution. A variety of factors inform architect interpretation including, enforcement, actor behaviour, architect behaviour and external factors such as the growth of non-agricultural employment. Architects interpret the efficacy of the institution by measuring its ability to shape the behaviour of actors according to their institutional objectives. Constant feedback loops inform the institutional architects of the efficacy of the current institutional arrangements. Enforcement and actor behaviour is analysed by architects to assess whether their objectives are being met and whether enforcement or the formal regulations need to be adjusted to better meet these objectives, or in some cases, whether the actual institutional objectives themselves need to be adjusted or dropped or new objectives created.

Institutions are path dependent. Architect interpretation of the institutional arrangements is shaped by the formal regulations and objectives they inherit. Past architect behaviour is the baseline for how an architect interprets the efficacy of the institutional arrangements. This seems to be particularly important in China where so much of ones' political legitimacy is defined by continuity with past leaders' goals and directives. The architects of the huji institution have maintained the 1958 Hukou Registration Regulations and this important regulation still acts as the basis for contemporary policy decisions. The formal regulations they inherit become the starting point for their action. For example, the division of rural and urban employment in the 1960s and 1970s through agricultural and non-agricultural hukou significantly shaped the labour market in China. When rural migrants began increasingly residing and working in urban centres without hukou transfer the institutional architects were not free to implement whatever regulation they felt fit as is often the assumption of institutional architects in a 'communist state'. Rather, the architects were bound by past architect behaviour that 
introduced and codified the formal regulations of the huji institution and set up the means to enforce them. In order to preserve the current and future legitimacy of their leadership, architects are careful to respect past decisions and not contradict or critique past regulations. ${ }^{538}$ Change is therefore a move from an existing position to another position over time, from one set of institutional arrangements to another, not the creation of new institutional arrangements from a 'clean slate'. Architect interpretation of the institutional objectives, the efficacy of enforcement of the formal regulations to meet those objectives and the influence of past arrangements on their cognition are all critical to informing architect behaviour. The huji institution has maintained continuity in many of its objectives. Local authorities still use huji regulations to maintain social stability, manage and restrict urbanisation, promote economic development and modernisation and to overall strengthen the party-state. But in recent times the regulatory means of achieving these goals has changed considerably. Most change has occurred in the formal regulations to use huji to accelerate economic development. Regulation and enforcement increasingly focuses on managing population flows to attempt to match them to employment opportunity, type and scale. Architects over the period of study have made formal regulatory changes including the introduction of temporary permits and competitive hukou transfer categories to meet these institutional objectives.

Just as a variety of external factors influence the way actors interpret enforcement of an institution they also influence the way architects view the efficacy of institutional arrangements and enforcement. These external forces also have a bearing on the collective institutional objectives formulated by the institutional architects. For example, local government officials in Beijing came to realise in the 1980s that the growth of the

\footnotetext{
${ }^{538}$ At times this requires a great deal of creativity, such as the construction of the term the 'socialist market economy' to maintain a rhetorical link to socialism whilst introducing market reforms.
} 
secondary and tertiary sector that relied heavily on rural labour was a key to local and national development. The institutional goal to use the huji institution to allocate labour and prevent agricultural hukou holders from residing and working in urban areas evolved into the new institutional goal to accelerate economic development through managed rural to urban labour flows and temporary residency permits. Whilst migrant agency is an important factor in changing architect objectives (the fact that enforcers could no longer stop rural to urban migration meant it needed to be accommodated) the most significant factor was the economic benefits temporary residency was found to have during the early 'experimental' period at the beginning of the 1980s. Therefore, architects are heavily influenced by external factors as they interpret the efficacy of the enforcement of the formal regulations to meet their objectives and even the efficacy of the objectives themselves. Behaviour follows this interpretation in the form of action. This action is a direct causal link to the formal institutional arrangements. Architects have the power to change or maintain the formal regulations and will make formal changes to the institutional arrangements based on their interpretation of how to better shape the behaviour of actors in a constantly changing socio-economic environment in order to better meet existing, modified or new institutional objectives. This action is again constrained and enabled by a variety of external and internal factors.

Change to either the formal regulations or to the institutional objectives occurs because enforcement of the formal regulations no longer shapes actor behaviour in the desired manner. Change originating from these external factors represents exogenous change. This change does not have to be a 'shock' to play a significant role in emerging institutional regulations. In fact, external factors continuously play an important role in emerging huji regulations because they continuously shape actor and architect interpretation of the institutional arrangements and enforcement. Therefore, change in 
informal institutional practices is a continuous process. This is often hidden because change in the formal institutional arrangements is not continuous or fluid but rather sporadic and bound by institutional objectives which remain resistant to change. Two types of change to the formal regulations of an institution occur when external factors change the manner in which enforcement of regulations shape the behaviour of the actors so they diverge from achieving the existing institutional goals of the institutional architects. The first involves architects adjusting the formal institutional arrangements and enforcement so they better meet existing goals by shaping the behaviour of the institutional architects. The second involves adjusting, dropping or creating new institutional objectives as well as new formal regulations to achieve those new or reformed objectives. The first can be described as institutional adjustments to better meet existing goals when facing non-compliant actor behaviour. The second is significant 'deep' institutional reform.

This is also the case for a variety of 'internal' factors. Endogenous factors that lead to formal institutional change remain a contentious area of debate because institutional architects are not isolated actors. Their action takes place in an environment where a number of external factors act as constraints, enablers and influences on their objectives, psychology and behaviour. To decipher what is 'internal' to the institution and what is 'external' is largely impossible. Architects and enforcers act both within a socioeconomic environment and within a government and party structure. The architects and enforcers of the formal regulations of the huji institution are local and central government officials and party members. The MPS and local public security officials are responsible for the day to day enforcement of the formal regulations. Hukou transfer is enforced by officials in local public security bureaus, personnel bureaus and the labour and social security bureaus. Municipal governments set hukou transfer and 
temporary residency targets based on information from economic advisors and urban planning officials. Changes within the culture and governing style of the party-state have significantly influenced enforcement and design of the formal huji regulations over the period of study.

These changes include a general move to a more 'hands-off' and regulatory approach to the day to day running of an increasingly privatised domestic economy and the devolution of responsibility to local government officials. These two broad political trends in the Chinese political system can also be seen in evolving formal regulations of the huji system. Over the period of study officials of the party-state have encouraged the development of economic entrepreneurialism and the market economy. Changes in the formal regulations of the huji institution can therefore be seen as part of broader central and local government changes that sought to accelerate economic development through the incremental move to market economics and regulatory enforcement of economic practice as opposed to economic planning. The second broad political trend is the devolution of responsibility to local government. In the late 1980s and early 1990s this trend was recognizable in huji management by the increasing prevalence of illegal hukou sales and local variation in hukou transfer policies. By the mid-1990s localisation of hukou policy was formally adopted by central government through a variety of regulations that gave local governments the power to set hukou transfer and huji population growth targets. This allowed significant variation in huji management to suit regional economic development goals whilst maintaining a degree of uniformity through increased nationalisation of communication and registry details. These moves can be seen as part of a general government reform trends within the party-state. 


\subsubsection{Changing Formal Institutional Arrangements}

Therefore, informal institutional change is an ongoing and constant process that creates the conditions for formal institutional change. Feedback loops inform both actor and architect behaviour. Actor behaviour is shaped by the enforcement of the formal regulations and their interpretation of past individual and collective experience. Change occurs when enforcement of the institutional arrangements no longer shapes the behaviour of actors to meet the objectives of the institutional architects or when the objectives are modified, dropped or new ones introduced. This occurs because actor behaviour is also influenced by a variety of external factors and architect and enforcer behaviour is influenced by a variety of external and internal factors. In the case of the huji institution, it is clear that early non-compliance with the 1958 huji regulations preventing non-sanctioned employment of agricultural hukou holders in urban areas preceded formal regulatory change (the introduction of temporary permits) and that current long-term 'temporary' settlement is influencing emerging hukou regulations. A variety of external factors influenced the behaviour of actors, such as increased employment opportunities in Shenzhen for example, and this changed the way the actors responded to the enforcement of formal hukou policy. At the same time, the architects of the institutional arrangements interpreted the formal institutional arrangements differently in light of the changing actor behaviour and also in light of their changing conceptualisation of how the formal regulations should shape the behaviour of actors. Architects increasingly came to view non-huji migration to urban centres as a means to achieve the goal of accelerating economic development. Shenzhen is the clearest case of this. This then led them to change the formal regulations to account for the new socio-economic environment and allow them to achieve their institutional goals by different regulatory enforcement intended to shape the behaviour of the actors in the new socio-economic environment. 
This shows that change cannot be attributed purely to actor agency or state planning or exclusively to external factors such as the growth of the market economy and employment opportunities for agricultural hukou holders in urban areas. Rather, change is a constant process that is influenced by a multitude of interdependent variables. If one part of the dynamic system is modified, this will flow through to all parts of the system of relations. The degree and type of informal practices created and the extent they diverge from the formal institutional arrangements and/or new institutional objectives, will determine the degree and type of formal institutional change. Causal relations between these factors remains unclear due to the multiplicity of relations, the interdependency of variables and the long causal chain to formal institutional change. Clearly institutions shape the behaviour of actors through enforcement but it is just as true to argue that the behaviour of actors shapes the formal institutional arrangements. Both actors and architects have goals and objectives and are influenced by factors external to the institutional arrangements. Power lies with the architects and enforcers of the institution but power also lies with actors whose behaviour is the definitive test of the efficacy of the institutional arrangements. Both actors and architects influence each other to some degree and both are constrained and enabled by the institutional environment. In short, formal institutional change is a dynamic process.

\subsection{Theoretical significance}

Historical institutionalism is dominated by theories of institutional stability, institutional stickiness and path dependency. Theories of institutional change for most involve exogenous shocks and theories of endogenous change remain few. This study has shown that there is a great deal of continuity and stability in the objectives local authorities have hoped to achieve through huji regulations. It has also shown that huji regulations have experienced two significant changes, the introduction of temporary 
permits and competitive inward hukou transfer rates. Existing theories fail to adequately account for the process of change explained above.

\subsubsection{Economic Models of Migration, Solinger and Wang}

The reforms outlined above show some liberalisation of huji management but make clear the huji institution still acts to slow urbanisation for both employment and settlement. The huji institution still acts as an intervening variable in the labour market, in the Lewis transition and the overall pattern of urbanisation in China. Economic models of migration, such as those outlined in the literature review, fail to identify this important 'intervening variable'. Whilst the results of this study show that economic migrations in China confer with push and pull theories and the assumptions of the Lewis Transition, they also show clearly how the formal institutional arrangements of the huji system have a strong and ongoing bearing on actor behaviour. The failure of these models to include this intervening variable skews results and leads to predictions with obvious inaccuracies. This observation should not be brushed aside as a short-term nullity of the lingering planned economy. As forms of huji management have been around for millennia and China's polity is far from liberalised, it is important for researchers to incorporate the affect of institutions like the huji system when they are conducting research on China's economic development. It is also highly likely that formal institutions in developed economies also shape the economic behaviour of their residents. Therefore, both macro and micro economic studies should not ignore the important role formal institutions play shaping the economic behaviour of their residents. This is a significant finding for scholars researching China's economic development that utilise models based on findings from cases of development in western states or current development in other developing countries. 
Solinger (1999) identified the significance of China's move to market economics for the urban rationing regime and the huji institution. The systematic dismantling of the urban rationing regime has continued to decrease the urban benefits local huji residents enjoy over their more recent non-huji neighbours but the importance of the huji institution to socio-economic opportunity remains. Solinger identified the importance of migrants, markets and the state and argued they were mutually dependent. This study has found that the economic change China has experienced over the reform period has given rise to hundreds of millions of migrations and that these migrations have been influential on evolving huji regulations. Solinger conceptualised the impetus for changing state policy in the agency rural migrants were exerting on the state structure. This study has found that this is true but only in part. Changing state policy and the formal rules of the state have come about through a combination of changing economic rationales that have influenced migrants, employers and local authorities keen to economically develop their region. As the socio-economic conditions of reform China have experienced great change, so too have the formal rules of the huji institution. As explained above, the dynamics of formal regulatory change cannot and should not be reduced and merely attributed to migrant agency. Nor should it be reduced exclusively to the role of state planning or to the rise of markets as some other studies do. The reality is far more complicated. A variety of actors with a variety of interests form fluid informal practices within changing socio-economic environments and architects and enforcers act within changing institutional cultures and settings in response to these changes.

Wang (2005) conceptualised huji reform in China as a move from an exclusively type III form of institutional exclusion to a predominantly type III form of institutional exclusion with elements of type II. The results in this study also confirm this finding. Huji regulations have increasingly prioritised the attributes of the applicant in hukou 
transfer particularly focusing on level of education and skills and business and investment potential. There remains a considerable degree of type III institutional exclusion but a trend towards further prioritising of type II is clear. China's huji reforms are also a long way from abolishing the system and regulating migration and settlement primarily through a type II form of institutional exclusion overseen by markets as Wang concludes. The introduction of temporary residency, found to be a significant change in the formal institutional arrangements, is also evidence of these processes identified by Wang and an important addition to his conceptualisation of changing institutional division in China's hukou system.

\subsubsection{Theories of Institutional Change}

Theories of institutional change are dominated by path dependency and institutional stickiness. There is a 'conservative bias' that views changes in formal institutional arrangements as mere adaptation of the institution to better shape the behaviour of actors in the desired way. This 'conservative bias' is lacking for the following reasons: Firstly, formal institutional change occurs when the 'rules' of the institution change. If these 'rules' change to better meet existing institutional objectives, the formal institutional arrangements have still changed. Studies that fail to point out the significance of such changes are confusing the level of analysis. Whilst change in institutional objectives is significant deep reform of the institution, changes in formal arrangements to better meet existing institutional objectives can also be significant and should therefore not be ignored. Secondly, this study has shown that informal institutions (enforcement and actor behaviour or what some scholars term enactment) are constantly in flux. Institutions in a practical 'real-worldly' sense, are always changing as changes in the institutional environment and psychology of the actors and enforcers are never static. Even if the informal institution in practice does not lead to changed formal institutional arrangements, to ignore the fluid nature of informal 
institutions is to miss much of the importance of how institutions operate and shape the behaviour of actors in practice. Lastly, by ignoring the fluid and dynamic nature of informal institutions, scholars run the risk of incorrectly attributing changes in formal institutional arrangements when they occur. This study has shown clearly that the behaviour of institutional actors has the potential to influence how the institutional architects interpret the functioning of the institution and lead them to make changes to the formal institutional arrangements or even to their objectives for the institution. These studies suggest that studies that focus exclusively on path dependency, stability or institutional stickiness, are failing to tune their analysis to the constant process of dynamic change that occurs in the enactment of the formal institutional arrangements.

Whilst change is a constant feature of informal institutional practices, the formal institutional arrangements are, as the above scholars point out, 'resistant to change'. The costs of formal institutional change are high. Moreover, most institutions operate within a 'band of acceptability' whereby the shaping of actor behaviour does not have to be precise to be effective, merely within a certain range. The model of institutional change proposed in the previous section accounts for this by proposing that the architects of an institution construct formal institutional arrangements to shape the behaviour of actors to meet the overarching institutional objectives. These objectives are often broad policy objectives such as to 'accelerate economic development' or to 'manage and restrict urbanisation and migration'. The formal institutional arrangements are then constructed and enforced to meet these objectives by shaping the behaviour of actors in the desired manner. As institutional objectives are broad, the gap between informal institutional practice and the formal institutional arrangements needs to reach a point whereby the architects no longer view the arrangements as being in their interests. A minor gap however will result in no such formal institutional change. 
The model of institutional change proposed in the previous section highlights the importance of studying institutions as dynamic systems. It highlights a variety of groups in an institutional framework (actors, enforcers, architects) and notes that within these categories there are again different groups with differing interests. ${ }^{539}$ The relationship between these groups is not unidirectional as a linear assumption of institutional analysis suggests. Institutions do shape the behaviour of actors, but actors also shape the interpretation and behaviour of architects who construct the institutional arrangements and oversee enforcement. Moreover, a significant finding from this thesis is that institutions operate within a setting in which forces external to the institution will change the operation of the informal institution in practice even when there has been no formal institutional change. ${ }^{540}$ Lastly, the relationship between the institutional culture and the institutional architects has a significant bearing on their interpretation and behaviour. This suggests more focus needs to be put on how changes in the socioeconomic environment (factors external to the institutional arrangements) and how changes in the broader institutional culture (factors internal to the institution) have a bearing on the process of formal institutional change. These findings suggest studies of institutional change that posit linear lines of unidirectional causality or other studies that isolate architect behaviour from the broader institutional culture and environment are reducing and simplifying to a level of analysis that provides very little insight into the actual process of institutional change.

These findings are significant for political and economic studies of China. Firstly, China has been conceptualised as an authoritarian state where elite-led decision-making determines the nature of the politico-economic environment. This study, however, finds

\footnotetext{
${ }^{539}$ For example, there are rural and urban, local and non-local institutional actors as well as public security architects and architects from the city planning division.

${ }^{540}$ Just as the informal institutional practice will shape the institutional environment.
} 
a great deal of evidence to suggest China's state-led development programme is in reality more a 'state-shaped' process of development. Whilst the study shows that the institutional architects in China have great power to shape the behaviour of residents through their enforcement and construction of formal regulations it has also shown that this power is far from exclusive. In fact, the actors in the institution have enormous power to shape the institutional arrangements through their action. Neither actors nor architects operate 'freely' as each are bound by differing constraints. Actors are shaped by the consequences of enforcement of the formal regulations and the actual socioeconomic conditions they encounter as well as the limits of their own cognition. Architects are shaped by the institutional arrangements they inherit that act to maintain their political legitimacy, by their own changing cognition, by wider institutional objectives and by the changing socio-economic environment. This suggests, political and economic reform in the Chinese party-state is an ongoing process of negotiation in which a variety of actors with different interests try to manoeuvre to obtain what they at that time view to be in their collective and individual interests. This is a complex process fraught with mistakes but one that ultimately leads to greater freedoms for nonstate actors as evidenced in the controlled liberalisation of the hukou institution over the period of study.

In sum, the process of formal institutional change is dynamic. Change occurs when formal institutional arrangements no longer shape the behaviour of actors to meet the institutional objectives or when the objectives themselves change. In the first instance, there are many factors external to the institutional setting that can change the way enforcement of formal institutional arrangements shape the behaviour of the actors leading to formal change. In the second instance, both external and internal factors have a bearing on architect interpretation and behaviour that lead to formal institutional 
change. This suggests future studies need to focus on these two processes of change to understand better the dynamic process of formal institutional change.

\subsubsection{Research Shortcomings and Future Research Questions}

Two major research shortcomings have been identified. The first is a lack of focus on the cognition, institutional culture and group dynamics of the architects and enforcers of the huji institution. Understanding the culture of the Chinese bureaucracy, the process of decision-making and the general psychological changes that have occurred over the reform era would greatly aid our understanding of the formal institutional changes identified. The second relates to the methodology. The research design of this thesis has utilised the inductive method. This has involved observing the process of formal institutional change in China's huji system and from these observations producing a specific claim in the form of a model of institutional change in China's huji system. This research methodology was employed due to the general lack of understanding of the formal institutional significance of China's huji regulations and due to the general lack of viable theoretical models of institutional change that could be used to generate testable hypotheses. This methodology has been beneficial to this research but also has many limitations. The task now for researchers is to test this model of institutional change in the context of Chinese development and elsewhere through deductive methodologies.

These research shortcomings and unanswered questions point toward future research endeavours. In particular, the process of change identified has been shown to be complex and dynamic. To study such a process two methodologies are suggested. The first involves generalising the model of institutional change to other institutions in China. This will help refine the model and show if institutional change is a universal phenomenon or if there are a variety of institutional processes occurring in different 
cultural, political and economic settings. The results from this study point the author to predict institutional change is a universal process as cultural, economic and political factors can be accounted for within the model proposed above. The second future research endeavour involves isolating parts of the model and testing the relationship between variables. This will require a shift to the deductive methodology and more rigorous use of scientific methodology. Whilst the inductive method has allowed the researcher the chance to observe and explore the process of institutional change in China's huji institution from which a model has been created, such a methodology does not provide a predictive model because the assumptions in the model remain 'untested'. Moreover, regarding future studies of the huji institution, a greater focus on the institutional culture of the institutional architects is required to identify endogenous factors and how these factors relate to the overall process of change. Similarly, more focus needs to be put on the cognitive factors involved in architect and actor interpretation of formal institutional arrangements in the institutional environment that act as the cognitive precursors to behaviour. Finally, studies of institutions in general suffer from a heavy focus on path dependency and institutional stability. It is hoped that the separation of formal institutional arrangements enforced to meet institutional objectives and the informal institution in practice can provide a productive theoretical framework for distinguishing between change and continuity.

\subsection{Conclusion}

This research has used a historical institutionalist approach to explain formal institutional change in China's huji institution over the period 1978 to 2007. The major finding of the study is that the huji institution has exhibited both change and a great deal of stability. In terms of stability, the huji institution still acts as an important intervening variable for economic development, migration and urbanisation and to maintain social stability and strengthen the rule of the party-state. In terms of change, the formal 
arrangements of the huji institution are considerably different to those of 1978. The major changes include, liberalisation of labour migration through the introduction of temporary residency permits, limited liberalisation of hukou transfer through competitive hukou transfer policies, the decentralisation of hukou decision-making and policy-making and the inclusion of modern values of efficiency and equality into the huji paradigm. Whilst equality as a modern value in China is nascent in huji policymaking, increasing calls from the emerging civic rights movement and the lowering of discrimination suggest this will continue to evolve in future. Efficiency on the other hand, has been found to be at the basis for nearly all significant formal changes over the period of study. This suggests that once isolated huji architects and enforcers are increasingly taking into consideration the interests of an increasingly influential group of employers in urban areas. Future reform relies not so much on the need to create greater economic efficiency but on the need to secure the equality of Chinese citizens. For as this study found, without moves in this direction, the efficacy of huji policy is at risk of bringing the entire Chinese development strategy into jeopardy creating an unstable and potentially catastrophic political situation.

The inductive methodology has focussed on two tasks, explaining what changes have occurred and explaining how and why these changes came about. The major theoretical insights from the study are that institutional change is a dynamic process in which a variety of factors both external and internal to the institution can affect change; that no isolatable linear change was found and that change is seen to reside in the 'gap' between the informal institution in practice and the formal institutional arrangements. This gap is created in two ways. The first occurs when socio-economic factors change the way actors interpret enforcement of the formal institutional arrangements leading to changed actor behaviour without formal institutional change. The significance here is that 
external factors can change the behaviour of actors that then lead architects to reevaluate the formal institutional arrangements in light of the new actor behaviour. If the gap created by these external factors is great enough this will lead the architects to change the formal institutional arrangements to better meet their institutional objectives or in some cases to even change the objectives themselves. The second process of change identified occurs both through changing factors external to the institution and through internal changes in the broader institutional culture. This second track of institutional change occurs when these factors change the cognition of the institutional architects leading them to create new institutional objectives that require new formal institutional arrangements.

Therefore, formal institutional change is a dynamic process in which a variety of factors come to bear on the interpretation and behaviour of the institutional architects. These factors are usually expressed through changed actor behaviour but can at times be expressed through the institutional culture itself. Socio-economic factors, particularly the increasing marketization of the Chinese economy and the growth in economic disparity (east/west \& rural/urban) have created ideal conditions for economic migrations that have led to behaviour diverging from the formal institutional arrangements of the huji institution that has led to a process of incremental formal institutional change to better meet the existing objectives of the huji institution. At the same time the broader institutional culture of the party-state has itself experienced change. This has led to the adaptation of existing huji objectives to better meet the changing socio-economic and politico-economic rationales of the time.

In sum, informal institutions in practice are constantly in flux leading to formal institutional change in the formal institutional arrangements when the gap grows to the 
extent that the institutional objectives are no longer being generally met. A parallel process of formal institutional change occurs through changes in the institutional culture as brought about by socio-economic change and internal cultural evolution. These changes represent a general prioritising of the modern values of efficiency and equality, though far more the former than the latter. 


\section{Appendix I - Timeline of Institutional Change}

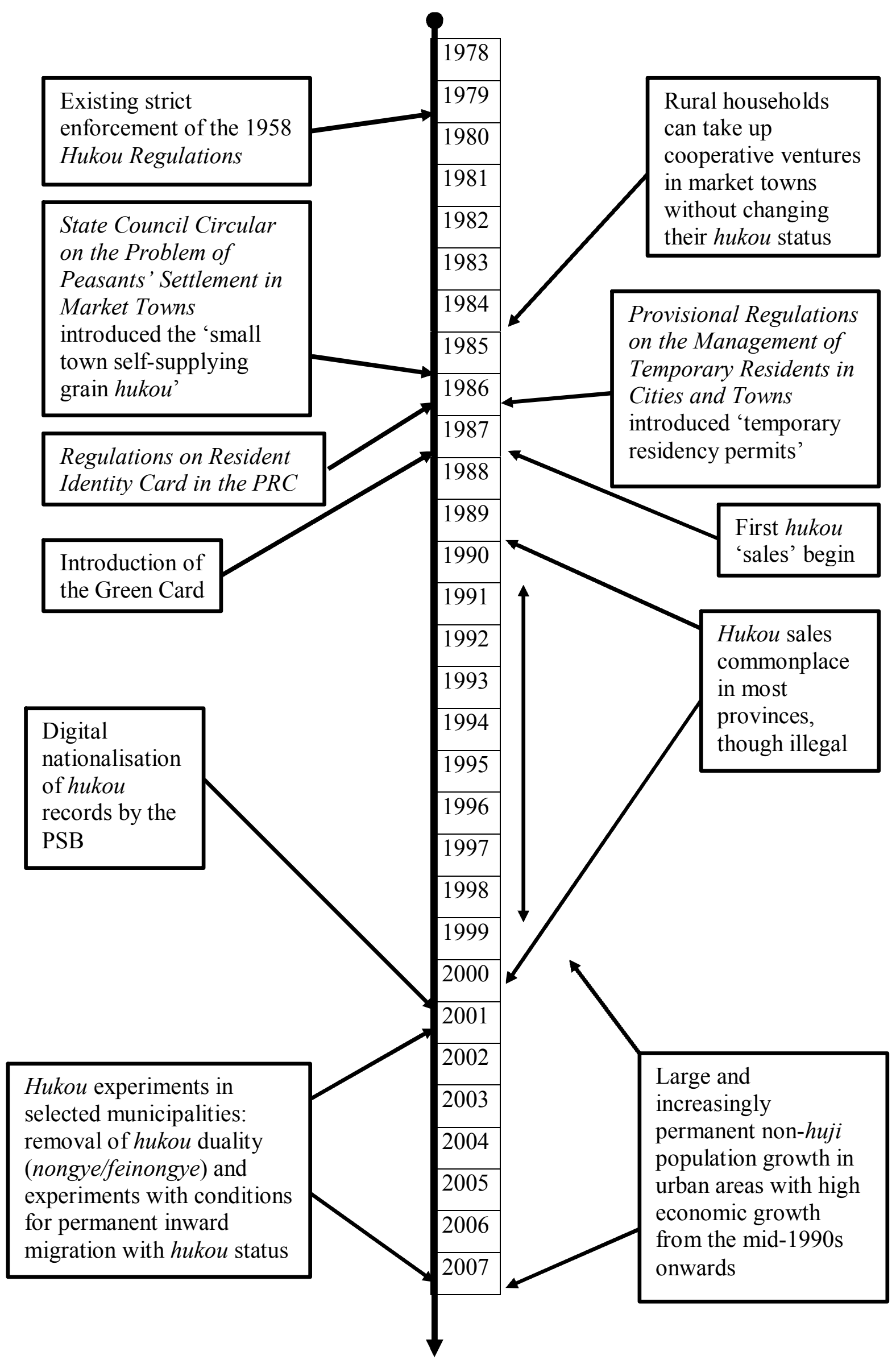




\section{Appendix II - Glossary of Terms}

In Alphabetical Order

1. 保甲制度 (baojiazhidu): 'Mutual responsibility system' - used by both Ming and Qing governments to register the population.

2. 城市化 (chengshihua): 'urbanisation'. 城市 (chengshi) means 'city'. This type of urbanisation is usually used to mean 'urbanisation from above' or urbanisation whereby people move from rural areas to urban areas.

3. 城镇化 (chengzhenhua): 'urbanisation'/'urbanisation from below'. 城镇 (chengzhen) means 'towns and small cities'. 城镇化 refers to the modernization of town or rural areas so they become synonymous with urban areas. 城镇化 is not synonymous with urbanization in the sense of people migrating from rural to urban areas. See Ma and Lin (1993) and Liang et al. (2002) for more detail. ${ }^{541}$

4. 城镇户籍 (chengzhen huji), 城镇户口 (chengzhen hukou): 'urban household registration'.

5. 打工妹 (dagongmei): a combination of 'part-time worker' and 'little sister'

6. 单位 (danwei): 'work unit'

7. 改革开放 (gaige kaifang): 'reform and opening'. This group of policies began at the end of 1978 and included the Four Modernisations (四个现代化: Agriculture; Industry; Science and Technology; National Defence) as well as the allowance of private enterprise, individual capital accumulation and opening China to foreign investment, global markets and joint enterprises in China.

8. 关系网 (guanxi wang): A person's network of relations.

9. 户籍警察 (huji jingcha): 'huji police'

10. 户籍人口 (huji renkou) 非户籍人口 (feihuji renkou): the huji population and non-huji population. This refers to the hukou status of people living in an urban area. In recent times officials have distinguished between residents with local hukou status and those without using these terms.

11. 户籍制度 (huji zhidu): 'household registration system'. The term 户口制度 (hukou zhidu) is also commonly used to refer to the 'household registration system' but strictly speaking hukou refers to an individual household whereas huji refers to the system of household registration. This system is dualistic. There are two main categories of 'household registration', 'urban household registration' for 'shimin' and 'rural household registration' for 'nongmin'. This duality is expressed as 农业和非农业户口 (nongye he feinongye hukou): 'agricultural and non-agricultural household registration'. The second duality is local/non-local.

12. 户口 (hukou): 'household registration'. This is the individual status of people in China as defined by their registration under the huji system.

13. 户口所在地 (hukou suozaidi): permanent hukou location. This is the zone in which a resident's hukou is held by the local public security organ. In this area a resident can vote and receive local state services such as health and education if available. If a person moves without obtaining hukou transfer their hukou remains at this permanent hukou location.

\footnotetext{
${ }^{541}$ Ma and Lin, "Development of Towns in China: A Case Study of Guangdong Province.", Liang, Chen, and $\mathrm{Gu}$, "Rural Industrialization and Internal Migration in China."
} 
14. 户口转移 (hukou zhuanyi) 户口迁移 (hukou qianyi) 户口迁入 (hukou qianru): Hukou transfer and inward hukou transfer. Permanent transfer of a resident's hukou status by the MPS and other local officials to a new hukou location.

15. 计划 (jihua): literally 'planned'. This term refers to state socialist political, economic and social planning. In relation to migration, a 'planned' migration refers to migrations that are state sanctioned or initiated. Therefore, the migration of millions of Chinese students to rural areas during Mao's 'rustification' movement, were 'planned' migrations because they were initiated by Government planners.

16. 计划外 (jihuawai): 'outside the plan'. This term refers to activities that occur independently of state socialist political, economic and social planning. In relation to migration, 'outside the plan' migration refers to migrations that occur independently of state planning. 'Nongmingong' are defined by their absence of household registration in the areas where they live and work, and so, by definition their migration is 'outside the plan'. With the advent of temporary residency permits and the scalling back of economic planning, this term is no longer used.

17. 家庭联产承包责任制 (jiating lianchan chengbao zeren zhi): 'household responsibility system' (HRS) or 'household contract system'. This system replaced the strict quotas rural communes were forced to produce for the planned economy. After the breakdown of the communes, families re-claimed their land and in 1981 the government finally introduced the HRS in which a drastically reduced portion of a farmer's crop (quota) was taken by the state at set prices allowing the remainder of the crop to be sold at market prices.

18. 粮票 (liangpiao): 'ration cards'.

19. 流动人口 (liudong renkou): the 'floating population'. This term is synonymous with 'nongmingong'. However, the term 'floating population' is often used to convey a lack of government oversight and regulation of 'nongmingong' as 'nongmingong' reside for most outside the traditional control mechanisms of the 'household registration system' and 'work units'.

20. 盲流 (mangliu): literally 'blind flow'. This term refers to 'unplanned' migration to the cities by 'nongmin'. Newspapers and government bodies in the 1950s and still today often describe this type of 'unplanned' migration and urbanization negatively. Many scholars, journalists, government officials and 'shimin' view 'outside the plan' migration as disorderly (无序 wuxu and 乱 luan), and as contributing to rising crime and decreasing social stability in the urban areas of China.

21. 农村户口 (nongcun hukou), 农业户口 (nongye hukou): 'rural household registration' and 'agricultural household registration'.

22. 农民 (nongmin): 'Peasant'. 农 (nong) refers to 'agriculture' or 'farming' and 民 ( $\mathrm{min})$ refers to 'people'. The term 'peasant' is commonly used to translate phrases such as 农民意识 (nongmin yishi) 'peasant mentality’ or 农民协会 (nongmin xiehui) 'peasant association'. However, in this thesis the term is rendered in pinyin as 'nongmin' to direct the reader to what defines 'nongmin', their 'rural household registration'. Many 'nongmin' are not 'peasants' in strict accordance with the English meaning (agricultural labourer or small farmer; a rural person). Many live and work in urban areas but remain 'nongmin' and are denied access to public goods and services. It is argued that the English word 'peasant' does not convey this meaning adequately.

23. 农民工 (nongmingong): literally 'rural people workers' or 'rural workers'. WEI Liqun (2006) states, "Nongmingong are predominantly defined by their 
household registration status remaining rural when they enter cities to work or are engaged in non-agricultural work in their local area or other areas of China." 542 Their 'rural household registration' limits their access to public goods and services to their registered rural location only. As they are not shimin of the area they are residing in and are for most denied permanent residency in urban areas, they have no right to access public goods and services even though they live, work and reside for most in these urban areas. Nongmingong have also been described as the 'floating population'.

24. 农业户口 (nongye hukou) and 非农业户口 (feinongye hukou) (or huji): agricultural and non-agricultural hukou/huji. This defines whether a resident is nongmin or shimin, agricultural or non-agricultural, rural or urban.

25. 农转非 (nongzhuanfei): to transfer from agricultural to non-agricultural hukou status.

26. 人口流动 (renkou liudong): 'population flows'

27. 'Registered residents': This term is used to describe those residents who live and work in the place of their household registration and therefore those people who are entitled to access public goods and services in that area. 'Nongmingong', by definition, are not 'registered residents' in their destination as their household registration remains 'rural' when they live and work in cities. They remain 'registered residents' in terms of their 'rural household registration' (at place of origin) but are not 'registered residents' at their place of destination.

28. 社会主义 (shehuizhuyi): 'socialism'. When used in China, this term almost exclusively refers to 中国特色社会主义 (Zhongguo tese shehui zhuyi) 'socialism with Chinese characteristics'.

29. 社会主义计划经济 (shehuizhuyi jihua jingji): 'socialist planned economy' often known as 计划经济 (jihua jingji), a 'planned economy'.

30. 社会主义市场经济 (shehuizhuyi shichang jingji): 'socialist market economy'.

31. 市民 (shimin): literally 'city people' but often translated as 'citizens' or 'city residents'. 市 (shi) refers to 'markets', 'cities' or 'urban areas' and 民 (min) refers to 'people'. In order to convey the privileged status 'shimin' have through their 'urban household registration' that gives them access to public goods and services in the relatively well developed urban areas of China that each is registered in (from Shanghai to Lhasa), and to avoid confusion with 'state citizenship' or the 'urban population' (many of who are nongmin), in this thesis the term is rendered in pinyin as shimin.

32. 'Transition': this term is translated in Chinese as 变迁 (bianqian). It is included in this list of terms because of the propensity for both Chinese and other scholars to use the term to describe the politico-economic changes occurring in China since 'reform and opening' began. Very different premises can underlie the use of the word. 'Transition' can refer to the move through the first stage of communism (socialism) toward a communist utopia. 'Transition' can also refer to a move from communism to a form of capitalism (socialist market economy).

33. 同乡 (tongxiang): People from the 'same village', meaning people that come from the same village, town, province or region of China that share economic and cultural similarities such as dialect.

34. 暂住证制度 (zhanzhu zheng zhidu): 'Temporary Resident Permit System'. Many 'nongmingong' who live and work outside the area of their household

${ }^{542}$ Wei Liqun 魏礼群. "正确认识和高度重视解决农民工问题（代序言）" [Properly Recognising and Placing High Importance on Resolving the Nongmingong Issue (Preface)]. p.1 
registration have a 暂住证 (zanzhuzheng) 'temporary residence card' that allows them to reside and work in the area specified on the permit but does not grant the holder the same benefits a permanently 'registered resident' is entitled to. The 寄住证 (jizhuzheng) 'card for residents living with others' is similar and is also used for residents (predominantly nongmin) permanently registered elsewhere but currently living and working in an urban area. Officials will often describe temporary permit holders as the 暂住人口 'temporary population'

\section{Notes on the Use of Chinese Names and Terms:}

1. Chinese words are presented in standard simplified Chinese text. Translation to English is provided but Romanisation is used only where it is deemed necessary that non-Chinese readers need to be able to pronounce the term to aid comprehension of the text (E.g., the term huji is Romanised and appears often in the text).

2. The pinyin Romanisation system standard in the PRC since 1979 (invented 1959) is used throughout and appears in italics.

3. Chinese references can be found in the 'References' section and in the lists of laws, regulations and directives. Chinese language references are not presented in pinyin form. Rather, Chinese is translated into English and the original Chinese characters are presented. 


\section{Appendix III - Relevant National Laws, Regulations and Directives}

\begin{tabular}{|c|c|}
\hline Date & Law, Regulation or Directive \\
\hline 1958 & $\begin{array}{l}\text { PRC Hukou Registration Regulation } \\
\text { 《中华人民共和国户口登记条例》 }\end{array}$ \\
\hline 1977 & $\begin{array}{l}\text { The Ministry of Public Security Regulations Regarding the Management of } \\
\text { Hukou Transfer } \\
\text { 《公安部关于处理户口迁移的规定》 }\end{array}$ \\
\hline 1977 & $\begin{array}{l}\text { Recommendations Regarding Earnestly Carrying Out State Council } \\
\text { Notification of 'The Ministry of Public Security Regulations Regarding the } \\
\text { Management of Hukou Transfer' 《关于认真贯彻〈国务院批转"公安部关 } \\
\text { 于处理户口迁移的规定"的通知〉的意见》 }\end{array}$ \\
\hline 1980 & $\begin{array}{l}\text { PRC Nationality Law } \\
\text { 《中华人民共和国国籍法》 }\end{array}$ \\
\hline 1980 & $\begin{array}{l}\text { Regulations Regarding Resolving Some Skilled Agricultural Cadre Having } \\
\text { Problems with State Grain and Oil supplies for their Families from the } \\
\text { Villages Migrating into Urban Areas } \\
\text { 《关于解决部分农业技术干部的农村家属迁往城镇由国家供应粮食问题 } \\
\text { 的规定》 }\end{array}$ \\
\hline 1984 & $\begin{array}{l}\text { State Council Notification Regarding the Problem of Nongmin Settling in } \\
\text { Market Towns } \\
\text { 《国务院关于农民进入集镇落户问题的通知》 }\end{array}$ \\
\hline 1984 & $\begin{array}{l}\text { Central Committee of the Chinese Communist Party Notification Regarding } \\
\text { Rural Employment in } 1984 \\
\text { 《中共中央关于一九八四年农村工作的通知》 }\end{array}$ \\
\hline $\begin{array}{l}1984 \\
\text { (enacted } \\
1985)\end{array}$ & $\begin{array}{l}\text { Provisional Regulations Regarding the Management of Temporary Residents } \\
\text { in Cities and Towns } \\
\text { 《关于城镇暂住人口管理暂行规定》 }\end{array}$ \\
\hline 1985 & $\begin{array}{l}\text { PRC Resident Identity Card Regulations } \\
\text { 《中华人民共和国居民身份证条例》 }\end{array}$ \\
\hline 1988 & $\begin{array}{l}\text { Notification Regarding Prevention of Public Sales of Urban Hukou by Some } \\
\text { Cities [and] Counties } \\
\text { 《关于制止一些市、县公开出卖城镇户口的通知》 }\end{array}$ \\
\hline 1989 & $\begin{array}{l}\text { Interim Provisions for Management of Temporary Identification Permits } \\
\text { 《临时身份证管理暂行规定》 }\end{array}$ \\
\hline 1989 & $\begin{array}{l}\text { Notification Regarding Strictly Controlling Overly Rapid Increase in } \\
\text { 'Nongzhuanfei' } \\
\text { 《关于严格控制 “农转非” 过快增长的通知》 }\end{array}$ \\
\hline 1991 & $\begin{array}{l}\text { Notification of Recommendations Regarding the Distribution of } \\
\text { 'Nongzhuanfei' Policy Management Work } \\
\text { 《关于 “农转非”政策管理工作分工意见报告的通知》 }\end{array}$ \\
\hline 1991 & $\begin{array}{l}\text { Notification Regarding Practically Resolving Difficulties the Masses Have } \\
\text { Processing Hukou } \\
\text { 《关于切实解决群众办户口难问题的通知》 }\end{array}$ \\
\hline 1991 & $\begin{array}{l}\text { Notification Regarding Issues Relating to Handling 'nongzhuanfei’ Housing } \\
\text { and Provisions for Personnel with 'Self-supporting Grain Hukou' } \\
\text { 《关于自理口粮户口人员 “农转非”办理户粮关系有关问题的通知》 }\end{array}$ \\
\hline
\end{tabular}




\begin{tabular}{|c|c|}
\hline 1992 & $\begin{array}{l}\text { Notification Regarding Implementing Locally Effective Urban Residential } \\
\text { Hukou Systems } \\
\text { 《关于实行当地有效城镇居民户口制度的通知》 }\end{array}$ \\
\hline 1992 & $\begin{array}{l}\text { Urgent Notification Regarding Resolving and Preventing the Flawed Method } \\
\text { of Publicly Selling Non-Agricultural Hukou } \\
\text { 《关于坚决制止公开出卖非农业户口错误做法的紧急通知》; }\end{array}$ \\
\hline 1992 & $\begin{array}{l}\text { Urgent Notice Regarding Immediate Cessation of Selling Non-Agricultural } \\
\text { Hukou } \\
\text { 《关于立即制止出卖非农业户口的紧急通知》 }\end{array}$ \\
\hline 1993 & $\begin{array}{l}\text { State Council Decision Regarding Huji System Reform } \\
\text { 《国务院关于户籍制度改革的决定》 }\end{array}$ \\
\hline 1994 & $\begin{array}{l}\text { Notification Regarding Resolving and Preventing the Continued Sale of Non- } \\
\text { Agricultural Hukou } \\
\text { 《关于坚决制止继续出卖非农业户口的通知》 }\end{array}$ \\
\hline 1994 & $\begin{array}{l}\text { Notification Regarding Using New Hukou Relocation Certificate, [and] } \\
\text { Hukou Permits } \\
\text { 《关于启用新的户口迁移证、户口准迁证的通知》 }\end{array}$ \\
\hline 1994 & $\begin{array}{l}\text { Notification Regarding Issues Relating to Hukou Transfer for Redeployed } \\
\text { Cadres, [and] Labourers } \\
\text { 《关于干部、工人调动办理户口迁移手续有关问题的通知》 }\end{array}$ \\
\hline 1995 & $\begin{array}{l}\text { Notification Regarding Introducing New Permanent Population Registration } \\
\text { Forms and Resident Hukou Registers } \\
\text { 《关于启用新的常住人口登记表和居民户口簿有关事项的通知》 }\end{array}$ \\
\hline 1995 & $\begin{array}{l}\text { Application Procedures for Temporary Residency Permits } \\
\text { 《暂住证申领办法》 }\end{array}$ \\
\hline 1995 & $\begin{array}{l}\text { Notification Regarding Earnestly Cooperating to Complete Small City and } \\
\text { Town Huji Reform Work } \\
\text { 《关于认真配合做好小城镇户籍改革工作的通知》 }\end{array}$ \\
\hline 1995 & $\begin{array}{l}\text { Report Regarding Establishing } 8 \text { Counties (Cities) as 'Small City and Town } \\
\text { Huji System Reform' Experiments } \\
\text { 《关于建议将八县（市）列为 “小城镇户籍制度改革” 试点的报告》 }\end{array}$ \\
\hline 1995 & $\begin{array}{l}\text { State Council Decision Regarding Issues with Reform and Improvement of } \\
\text { Rural Urban Huji Management } \\
\text { 《国务院关于改革和完善城乡户籍管理制度若干问题的决定》 }\end{array}$ \\
\hline 1997 & $\begin{array}{l}\text { Blueprint for Experiments in Small City and Town Huji Management Reform } \\
\text { 《小城镇户籍管理制度改革试点方案》 }\end{array}$ \\
\hline 1997 & $\begin{array}{l}\text { Recommendations Regarding Perfecting the Rural Huji Management System } \\
\text { 《关于完善农村户籍管理制度的意见》 }\end{array}$ \\
\hline 1997 & $\begin{array}{l}\text { State Council Notification and Endorsement of Ministry of Public Security } \\
\text { Recommendations for the Programme of Experiments in Reform of the Small } \\
\text { City and Town Huji Management System and Regarding Perfecting the Rural } \\
\text { Huji Management System } \\
\text { 《国务院批转公安部小城镇户籍管理制度改革试点方案和关于完善农村 } \\
\text { 户籍管理制度意见的通知》 }\end{array}$ \\
\hline 1997 & $\begin{array}{l}\text { 'Reply to Issues Related to Experiments in Reform of the Small City and } \\
\text { Town Huji Management System and Perfecting the Rural Huji Management } \\
\text { System' } \\
\text { 《关于小城镇户籍管理制度改革试点和完善农村户籍管理制度有关问题 } \\
\text { 的解答》 }\end{array}$ \\
\hline
\end{tabular}




\begin{tabular}{|c|c|}
\hline 1998 & $\begin{array}{l}\text { Job Specification for Processing Hukou [and] Identity Cards for Residents } \\
\text { 《办理户口、居民身份证工作规范》 }\end{array}$ \\
\hline 1998 & $\begin{array}{l}\text { Recommendations Regarding Resolving Several Issues with Current Hukou } \\
\text { Management Work } \\
\text { 《关于解决当前户口管理工作中几个突出问题的意见》 }\end{array}$ \\
\hline 1998 & $\begin{array}{l}\text { Notification Regarding Issues Relating to Carrying Out Putting into Effect } \\
\text { 'State Council Notification and Endorsement of the Ministry of Public } \\
\text { Security Recommendations Regarding Resolving Several Issues with Current } \\
\text { Hukou Management Work' } \\
\text { 关于贯彻落实《国务院批转公安部关于解决当前户口管理工作中几个突 } \\
\text { 出问题意见的通知》有关问题的通知 }\end{array}$ \\
\hline 1998 & $\begin{array}{l}\text { 1998 Experiments in Small City and Town 'Nongzhuanfei’ Population } \\
\text { Planning } \\
\text { 《1998 年试点小城镇 “农转非”人口计划》 }\end{array}$ \\
\hline 1998 & $\begin{array}{l}\text { Notification Regarding Making Known to Lower Levels the } 1998 \\
\text { Experiments in Small City and Town Rural Population Controlled Planning } \\
\text { of Processing Urban Permanent Hukou } \\
\text { 《关于下达 } 1998 \text { 年试点小城镇农村人口办理城镇常住户口控制计划的 } \\
\text { 通知》 }\end{array}$ \\
\hline 2001 & $\begin{array}{l}\text { Recommendations Regarding Accelerating Reform of the Small City and } \\
\text { Town Huji Management System } \\
\text { 《国务院批转公安部关于推进小城镇户籍管理制度改革意见的通知》 }\end{array}$ \\
\hline 2001 & $\begin{array}{l}\text { Notification by the MPS Regarding Issues Practically Implementing } \\
\text { 'Recommendations Regarding Accelerating Reform of the Small City and } \\
\text { Town Huji Management System' } \\
\text { 公安部关于贯彻落实《国务院批转公安部关于推进小城镇户籍管理制度 } \\
\text { 改革意见的通知》有关问题的通知 }\end{array}$ \\
\hline 2001 & $\begin{array}{l}\text { 15th Session of the Third and Fifth National Committee of CPPCC, and the } \\
\text { Central Committee of the Communist Party of China, State Council } \\
\text { Recommendations Regarding Accelerating the Healthy Development of Small } \\
\text { Cities and Towns } \\
\text { 党的十五届三中、五中全会和《中共中央、国务院关于促进小城镇健康 } \\
\text { 发展的若干意见》 }\end{array}$ \\
\hline 2004 & $\begin{array}{l}\text { PRC Resident Identity Card Law } \\
\text { 《中华人民共和国居民身份证法》 }\end{array}$ \\
\hline 2005 & $\begin{array}{l}\text { PRC Temporary Resident Identity Card Management Measures } \\
\text { 《中华人民共和国临时居民身份证管理办法》 }\end{array}$ \\
\hline
\end{tabular}




\section{Appendix IV - Relevant Beijing \& Shenzhen Laws, Regulations \& Directives}

\begin{tabular}{|c|c|}
\hline Date & Law, Regulation or Directive \\
\hline 1985 & $\begin{array}{l}\text { Beijing Municipal Government Regulations Regarding Hukou Management } \\
\text { of the Temporary Population (no longer in force) } \\
\text { 《北京市人民政府关于暂住人口户口管理的规定 <已经失效>》 }\end{array}$ \\
\hline 1985 & $\begin{array}{l}\text { Detailed Regulations [Regarding] Implementing 'Beijing Municipal } \\
\text { Government Regulations Regarding Hukou Management of the Temporary } \\
\text { Population' (no longer in force) } \\
\text { 实施《北京市人民政府关于暂住人口户口管理的规定》的细则<已经失 } \\
\text { 效> }\end{array}$ \\
\hline 1989 & $\begin{array}{l}\text { Notification Regarding Strengthening Personnel File Management of the } \\
\text { Floating Population } \\
\text { 《关于加强流动人员人事档案管理工作的通知》 }\end{array}$ \\
\hline 1989 & $\begin{array}{l}\text { Interim Provisions for the Personnel File Management of Labourers in } \\
\text { Beijing's Floating Population } \\
\text { 《北京市流动中的工人人事档案管理暂行规定》 }\end{array}$ \\
\hline 1994 & $\begin{array}{l}\text { Provisional Regulations Regarding Employment of Rural Inter-Provincial } \\
\text { Migrants } \\
\text { 《农村劳动力跨省流动就业管理暂行规定》 }\end{array}$ \\
\hline 1995 & $\begin{array}{l}\text { Shenzhen Special Economic Zone Temporary Personnel Management } \\
\text { Regulations } \\
\text { 《深圳经济特区暂住人员户口管理条例》 }\end{array}$ \\
\hline 1995 & $\begin{array}{l}\text { Interim Provisions for Huji System Reform in Shenzhen City } \\
\text { 《深圳市户籍制度改革暂行规定》 }\end{array}$ \\
\hline 1995 & $\begin{array}{l}\text { Beijing City Regulations for Huji Management of Personnel in Beijing from } \\
\text { Foreign Areas } \\
\text { 《北京市外地来京人员户籍管理规定》 }\end{array}$ \\
\hline 1995 & $\begin{array}{l}\text { Procedures for Managing the 'Beijing City Foreign Personnel Employment } \\
\text { Permit' } \\
\text { 《〈北京市外来人员就业证〉管理办法》 }\end{array}$ \\
\hline 1997 & $\begin{array}{l}\text { Experimental Procedures for Beijing City Suburban Small City and Towns } \\
\text { Establishing Experimental Urban Huji Management } \\
\text { 《北京市郊区小城镇建设试点城镇户籍管理试行办法》 }\end{array}$ \\
\hline 1997 & $\begin{array}{l}\text { Implementation Details for the Experimental Procedures for Beijing City } \\
\text { Suburban Small City and Towns Establishing Experimental Urban Huji } \\
\text { Management } \\
\text { 《关于转发北京市郊区小城镇建设试点城镇户籍管理试行办法实施细 } \\
\text { 则》 }\end{array}$ \\
\hline 1999 & $\begin{array}{l}\text { Interim Provisions of Beijing City for Attracting Talent and Processing } \\
\text { 'Beijing City Employment Residence Permit' } \\
\text { 《北京市引进人才和办理（北京市工作居住证）的暂行办法》 }\end{array}$ \\
\hline 2000 & $\begin{array}{l}\text { Notification of Problems Relating to Beijing City Personnel Bureau } \\
\text { Accepting Family Hardships of Graduates not Born in Beijing City } \\
\text { 《北京市人事局接受家庭有实际困难非北京生源毕业生有关问题的通 } \\
\text { 知》 }\end{array}$ \\
\hline
\end{tabular}




\begin{tabular}{|c|c|}
\hline 2000 & $\begin{array}{l}\text { Regulations for Beijing City Encouraging Students Returning from Abroad to } \\
\text { Carve out a Career in Beijing } \\
\text { 《北京市鼓励留学人员来京创业工作的若干规定》 }\end{array}$ \\
\hline 2001 & $\begin{array}{l}\text { Notification Regarding Issues Relating to Accepting } 2002 \text { Vocational School } \\
\text { Graduates not Born in Beijing City } \\
\text { 《关于北京市 } 2002 \text { 年接受普通高等学校非北京生源应届毕业生有关问 } \\
\text { 题的通知》 }\end{array}$ \\
\hline 2001 & $\begin{array}{l}\text { Procedures for Zhongguan Village Science and Technology Zone to Accept } \\
\text { Vocational Graduates not Born in Beijing City } \\
\text { 《中关村科技园区接受非北京市生源高校毕业生办法》 }\end{array}$ \\
\hline 2001 & $\begin{array}{l}\text { Implementation Procedures for Regulations for Beijing City Encouraging } \\
\text { Students Returning from Abroad to Carve out a Career in Beijing } \\
\text { 《北京市鼓励留学人员来京创业工作的若干规定实施办法》 }\end{array}$ \\
\hline 2001 & $\begin{array}{l}\text { Implementation Procedures Regarding Non-local Investors and Business } \\
\text { Owners Applying for Permanent Beijing Hukou } \\
\text { 《关于外地来京投资开办私营企业人员办理北京市常住户口试行办法》 }\end{array}$ \\
\hline 2002 & $\begin{array}{l}\text { Implementation Recommendations for Policy Relating to Highly Talented } \\
\text { Personnel from Hong Kong, Macao and Taiwan } \\
\text { 《香港、澳门和台湾地区高级人才来京工作有关政策的实施意见》 }\end{array}$ \\
\hline 2002 & $\begin{array}{l}\text { Notification Regarding the Beijing Municipal Government Endorsement of } \\
\text { the City Public Security Bureau Recommendations Regarding Accelerating } \\
\text { Reform of the Small City and Town Huji Management System } \\
\text { 《北京市人民政府批转市公安局关于推进小城镇户籍管理制度改革意见 } \\
\text { 的通知》 }\end{array}$ \\
\hline 2003 & $\begin{array}{l}\text { Notification Regarding Recommendations for Implementing the Beijing City } \\
\text { Employment Residence Permit System } \\
\text { 《关于实施北京市工作居住证制度若干意见的通知》 }\end{array}$ \\
\hline 2004 & $\begin{array}{l}\text { Notification Regarding Issues Relating to Accepting Vocational School } \\
\text { Graduates not Born in Beijing City in } 2004 \\
\text { 《关于北京市 } 2004 \text { 年接受非北京生源高校毕业生有关问题的通知》 }\end{array}$ \\
\hline 2004 & $\begin{array}{l}\text { Implementation Procedures for Interim Provisions Regarding Regulations of } \\
\text { Beijing City Encouraging and Attracting Talented People Exhibiting } \\
\text { Excellence in Culture or Sports Carving out their Career in Beijing } \\
\text { 《北京市关于鼓励和吸引优秀文化体育人才来京创业工作若干暂行规定 } \\
\text { 实施办法》 }\end{array}$ \\
\hline 2004 & $\begin{array}{l}\text { Notification of Interim Provisions Regarding Regulations of Beijing City } \\
\text { Encouraging and Attracting Talented People Exhibiting Excellence in } \\
\text { Culture or Sports Carving out their Career in Beijing } \\
\text { 《北京市关于鼓励和吸引优秀文化体育人才来京创业工作若干暂行规定 } \\
\text { 的通知》 }\end{array}$ \\
\hline 2004 & $\begin{array}{l}\text { Committee and Organisation Regulations for Beijing City Sporting and } \\
\text { Cultural Talent Qualifications } \\
\text { 《北京市优秀文化体育人才资格认定委员会组织工作章程》 }\end{array}$ \\
\hline 2005 & $\begin{array}{l}\text { Beijing City } 2005 \text { Procedures for Attracting Graduates not Born in Beijing } \\
\text { 《2005 年北京市引进非北京生源毕业生工作程序》 }\end{array}$ \\
\hline 2005 & $\begin{array}{l}\text { Notification Regarding Recommendations on Accelerating the Development } \\
\text { of the Capital's Financial Sector } \\
\text { 《关于印发促进首都金融产业发展的意见的通知》 }\end{array}$ \\
\hline
\end{tabular}




\section{References}

Amnesty International. "People's Republic of China: Internal Migrants: Discrimination and Abuse, the Human Cost of an Economic 'Miracle'." New York: Amnesty International, 2007.

AsiaNews.it. "Migrant Worker Condemned to Death: He Killed to Get His Wages." AsiaNews, http://www.asianews.it/index.php?l=en\&art=4050, 06.09.2005.

"Migrant Worker Sets Himself Ablaze in Tiananmen Square." AsiaNews, http://www.asianews.it/index.php?1=en\&art=6763, 21.07.2006.

Averill, Stephen C. "The Shed People and the Opening of the Yangzi Highlands." Modern China 9, no. 1 (1983).

Bakken, Børge. "Comparative Perspectives on Crime in China." In Crime, Punishment, and Policing in China, edited by Børge Bakken. Lanham: Rowman and Littlefield, 2005.

Beijing City Philosophy and Social Sciences Planning Office 北京市哲学社会科学规 划办公室. 《北京人口发展研究报告》[Research Report on the Growth of the Beijing Population]. 北京[Beijing]: 同心出版社[Tongxin Publishers], 2007.

Beijing City Research Group 北京市调研组. "北京市农民工管理和服务问题研究" [Research into Beijing City Nongmingong Management and Service Issues]. In 《中国农民工调研报告/国务院研究室课题组》[China's Nongmingong Research Report/Discussion Group of the Research Department of the State Council], edited by Wei Liqun 魏礼群 and Han Changfu 韩长赋. 北京[Beijing]: 中国言实出版社[China Yanshi Publishing], 2006.

Bell, Stephen. "Institutionalism." In Government, Politics, Power and Policy in Australia, edited by John Summers, Dennis Woodward and Andrew Parkin. NSW Australia: Pearson Education Australia, 2002.

Bian, Morris L. The Making of the State Enterprise System in Modern China: The Dynamics of Institutional Change. Cambridge: Harvard University Press, 2005.

Borjas, George J. "Economic Theory and International Migration." International Migration Review 23, no. 3 (1989).

Brandt, Loren, and Thomas G. Rawski, eds. China's Great Economic Transformation. New York: Cambridge University Press, 2008.

Brun, J.F., J.L. Combes, and M.F. Renard. "Are There Spillover Effects between Coastal and Noncoastal Regions in China?" China Economic Review 13, (2002): $161-69$.

$\mathrm{Bu}$, Kitty. "Beijing Olympic Clean up Sweeps out Migrant Workers." Reuters (21.07.2008), http://www.reuters.com/.

Buckley, Chris. "Migrant Workers Protest and Riot for 3 Days in East China." Reuters (14.07.2008), www.reuters.com/.

Cai Fang 蔡昉, and Lin Yifu 林毅夫. 《中国经济》[Chinese Economy]. 北京 [Beijing]: 中国财政经济出版社[China Finance Economics Publishing House], 2003.

Caira, Mara. "The Concept of Migration and Clandestinity in the Chinese Culture." Social Science and Information 47, no.4 (2008).

Castles, Stephen, and Mark J. Miller. The Age of Migration. New York: Guilford Press, 2003.

Chan, Kam Wing, and Will Buckingham. "Is China Abolishing the Hukou System?" The China Quarterly 195, no. September (2008).

Chan, Kam Wing, Ta Liu, and Yunyan Yang. "Hukou and Non-Hukou Migrants in China: Comparisons and Contrasts." International Journal of Population Geography no. 5 (1999). 
Chan, Kam Wing, and Li Zhang. "The Hukou System and Rural-Urban Migration in China: Processes and Changes." The China Quarterly no. 160 (1999).

Chen Biao 陈彪. 《关于深圳市 2007 年国民经济和社会发展计划执行情况与 2008 年计划 (草案) 的报告》 [Draft Report Regarding the Implementation of the Shenzhen City 2007 Socio-Economic Development Plan and the 2008 Plan]. edited by 深圳市发展和改革 [Shenzhen Bureau of Development and Reform]. 深圳 [Shenzhen]: 深圳市政府 [Shenzhen Municipal Government], 2008.

Chen, Guidi, and Chuntao Wu. Will the Boat Sink the Water? The Struggle of Peasants in 21st-Century China. Translated by Hong Zhu: HarperCollinsPublishers, 2006.

Cheng, Kai-Ming, Xinhuo Jin, and Xiaobo Gu. "From Training to Education. Lifelong Learning in China." Comparative Education 35, no. 2 (1999).

Cheng, Tiejun, and Mark Seldon. "The Origins and Social Consequences of China's Hukou System." The China Quarterly no. 139 (1994).

Chi Jianyu 池建宇, and Yang Junxiong 杨军雄. "中国户籍制度变迁的供求分析--从 农村经济改革角度作出的一种解释" [Analysis of Supply and Demand in China's Transitional Huji System: An Explanation from the Perspective of Rural Economic Reform]. 《经济体制改革》[Reform of Economic System] no. 3 (2003).

China Daily. "Migrant Children Stay Bottom of Class." People's Daily Online, http://english.peopledaily.com.cn/ 04.11.2004.

China Labour Bulletin. "Home." Hong Kong: China Labour Bulletin http://www.clb.org.hk/en/, 2009.

—. "Rural and Urban Disparity in China." China Labour Bulletin http://www.china-labour.org.hk/en/node/100454\#10a, 2009.

China Popin 中国人口信息网。《全国政协委员呼吁尽快制定适应发展 ‘户籍法”》

[National Political Consultative Conference Committee Appeal to Establish a 'Huji Law' Suitable for Development as Quickly as Possible]. 中国人口与发展 研究中心 [China Population and Development Research Centre], http://www.cpirc.org.cn/news/rkxw_gn_detail.asp?id=415.

Chow, Gregory C. China's Economic Transformation: Second Edition. Oxford: Blackwell Publishing, 2007.

Das, Dilip K. The Chinese Economic Renaissance: Apocalypse or Cornucopia? New York: Palgrave MacMillan, 2008.

Davin, Delia. Internal Migration in Contemporary China. London: MacMillan Press, 1999.

Deng, Xiaoping. "Building a (Sic) Socialism with a Specifically Chinese Character." In Excerpt from a talk with the Japanese delegation to the second session of the Council of Sino-Japanese Non-Governmental Persons. China: People's Daily, 1984.

Duan Minfang 段敏芳. "中国人口变迁流动现状及发展趋势" [Current Trends in the Development of China's Migration Flows]. 《中南财经政法大学学报》

[Journal of Zhongnan University of Economics and Law] 6, no. 141 (2003).

Dutton, M. R. Policies and Punishment in China. Cambridge: Cambridge University Press, 1992.

Fan, C. Cindy. China on the Move: Migration, the State, and the Household, Routledge Studies in Human Geography. Oxon: Routledge, 2008.

. "The Elite, the Natives, and the Outsiders: Migration and Labor Market Segmentation in Urban China." Annals of the Association of American Geographers 92, no. 1 (2002). 
"Of Belts and Ladders: State Policy and Uneven Regional Development in Post-Mao China." Annals of the Association of American Geographers 85, no. 3 (1995).

. "Urbanisation from Below: The Growth of Towns in Jiangsu, China." Urban Studies 31, no. 10 (1994).

French, Howard W. "Chinese Success Story Chokes on Its Own Growth." New York Times, $\quad$ http://www.nytimes.com/2006/12/19/world/asia/19shenzhen.html, December 192006.

Glaser, Barney G., and Anselm L. Strauss. The Discovery of Grounded Theory: Strategies for Qualitative Research. New York: Aldine, 1967.

Goldman, Merle, and Elizabeth J. Perry. "Introduction: Political Citizenship in Modern China." In Changing Meanings of Citizenship in Modern China, edited by Merle Goldman and Elizabeth J. Perry. Cambridge: Harvard University Press, 2002.

Goldstein, Steven M. "China in Transition: The Political Foundations of Incremental Reform." The China Quarterly no. 144 (1995).

Goodkind, Daniel, and Loraine A. West. "China's Floating Population: Definitions, Data and Recent Findings." Urban Studies 39, no. 12 (2002).

Guang, Lei. "The State Connection in China's Rural-Urban Migration." International Migration Review 39, no. 2 (2005).

Guo, Fei, and Robyn Iredale. "The Impact of Hukou Status on Migrants' Employment: Findings from the 1997 Beijing Migrant Census." International Migration Review 38, no. 2 (2004).

Hall, P. A., and R. C. R. Taylor. "Political Science and the Three New Institutionalisms." Political Studies 44, no. 4 (1996).

Harbin Rural and Urban Planning Bureau 哈尔滨市城市规划局. 《镇规划标准: 中华 人民共和国国家标准 gb 50188 - 2007》 [Town Planning Standards: People's Republic of China National Standards Gb 50188 - 2007]. 哈尔滨市城市规划局 [Harbin Rural and Urban Planning Bureau], 2007 http://www.hrbghj.gov.cn/view/caghxgfg/article/013238.html.

Hare, Denise. '"Push' Versus 'Pull' Factors in Migration Outflows and Returns: Determinants of Migration Status and Spell Duration among China's Rural Population." The Journal of Development Studies 35, no. 3 (1999).

Hay, Colin, and Daniel Wincott. "Structure, Agency and Historical Institutionalism." Political Studies XLVI, (1998): 951-57.

Hollifield, James F. "The Politics of International Migration: How Can We 'Bring the State Back in'?" In Migration Theory: Talking across Disciplines, edited by Caroline B. Brettell and James F. Hollifield. New York: Rouledge, 2000.

Hook, Brian. "China in the First Decade of Reform and Opening Out: An Edited View." The China Quarterly no. 143 (1995).

$\mathrm{Hu}$, Xiaobu, Gabe T. Wang, and Yimin Zou. "Political Economy of the Floating Chinese Population." Journal of Contemporary Asia 32, no. 4 (2002).

Huang, Ping, and Shaohua Zhan. "Internal Migration in China: Linking It to Development." In Regional Conference on Migration and Development in Asia. Lanzhou, China: People's Republic of China Ministry of Foreign Affairs, 2005.

Huang, Xianbi. "Guanxi Networks and Job Searches in China's Emerging Labour Market: A Qualitative Investigation." Work, Employment and Society 22, no. 3 (2008).

Huang, Yasheng. "China's Cadre Transfer Policy toward Tibet in the 1980s." Modern China 21, no. 2 (1995).

Jacka, Tamara. "Working Sisters Answer Back: The Representation and SelfRepresentation of Women in China's Floating Population." China Information 13, no. 43 (1998). 
Jia, Xijin, and Yusi Zhao. "China Civil Society Report: Chinese Civil Society Impacts on Urban Migration." Nautilus Institute for Security and Sustainable Development, 09.12.2008.

Jiang Lihua 江立华. "我国户籍制度的历史考察" [China's Huji System: An Historical Review]. 《人口世界》[Population World], 2002.

Kasinitz, Philip, John Mollenkopf, Mary C. Waters, and Jennifer Holdaway. "Becoming American/Becoming New Yorkers: The Second Generation in a Majority Minority City ": Migration Policy Institute, 2006.

Keister, Lisa A. "Adapting to Radical Change: Strategy and Environment in Piece-Rate Adoption During China's Transition." Organization Science 13, no. 5 (2002).

Kiser, Edgar, and Yong Cai. "War and Bureaucratization in Qin China: Exploring an Anomalous Case." American Sociological Review 68, no. 4 (2003).

Knight, John, Lina Song, and Huaibin Jia. "Chinese Rural Migrants in Urban Enterprises: Three Perspectives." The Journal of Development Studies 35, no. 3 (1999).

Lantai World 兰台世界. "高校户籍档案管理模式初探" [Elementary Exploration of the University Huji Archive Management Model]. 《兰台世界》[Lantai World], no. 15 (2007).

Lary, Dianny. "The "Static" Decades: Inter-Provincial Migration in Pre-Reform China." In Internal and International Migration: Chinese Perspectives, edited by Frank N. Pieke and Hein Mallee. Cornwall: Curzon Press, 1999.

Lee, Everett S. "A Theory of Migration." Demography 3, no. 1 (1966).

Lewis, W. A. The Theory of Economic Growth. London: Allen and Unwen, 1955.

Li Chengming 李成名, Yin Hao 印浩, Wang Jizhou 王继周, and Jin Yimin 金逸民. 《人口地理信息系统》[Population and Geography Information Systems], 地 理信息系统理论与应用丛书 [Geography Information Systems Theory and Application Series]. 北京[Beijing]: 科学出版社 [Science Press], 2005.

Li, Heming, Paul Waley, and Phil Rees. "Reservoir Resettlement in China: Past Experience and the Three Gorges Dam." The Geographical Journal 167, no. 3 (2001).

Li, Rose Maria. "Migration to China's Northern Frontier, 1953-82." Population and Development Review 15, no. 3 (1989).

Li, Siming. "Population Migration and Urbanization in China: A Comparative Analysis of the 1990 Population Census and the 1995 National One Percent Sample Population Survey." The International Migration Review 38, no. 2 (2004).

Li Guiru 李桂茹. "深圳一非户籍居民: 选举权与他若即若离" [A Non-Huji Resident in Shenzhen: The Right to Stand for Election Kept at Arm's Length] 《中国青 年 报》[China Youth Paper], http://news.xinhuanet.com/legal/200506/16/content_3091566.htm, 2005.

Liang, Zai. "The Age of Migration in China." Population and Development Review 27, no. 3 (2001).

. "Foreign Investment, Economic Growth, and Temporary Migration: The Case of Shenzhen Special Economic Zone, China." Development and Society 28, no. 1 (1999).

. "Patterns of Migration and Occupational Attainment in Contemporary China: 1985-1990." Development and Society 33, no. 2 (2004).

Liang, Zai \& Yiu Por Chen. "Migration and Gender in China: An Origin-Destination Linked Approach." Economic Development and Cultural Change 52, (2004).

Liang, Zai, Yiu Por Chen, and Yanmin Gu. "Rural Industrialization and Internal Migration in China." Urban Studies 39, no. 12 (2002). 
Liang, Zai, and Zhongdong Ma. "China's Floating Population: New Evidence from the 2000 Census." Population and Development Review 30, no. 3 (2004).

Liang, Zai, and Michael J. White. "Market Transition, Government Policies, and Interprovincial Migration in China: 1983-1988." Economic Development and Cultural Change 45, no. 2 (1997).

Lin Fei 林斐."人口流动与城乡发展：探索发展中国家的经验" [Population Migration and Urban-Rural Development: Exploring the Experiences of Developing Countries]. 《重庆工商大学学报（西部论坛）》[Journal of Chonqing Technical and Business University (West Forum)], 16, no. 6 (2006).

Lin, Justin Y, Gewei Wang, and Yaohui Zhao. "Regional Inequality and Labor Transfers in China." Economic Development and Cultural Change 52, no. 3 (2004).

Lin, Justin Yifu. "Rural Reforms and Agricultural Growth in China." The American Economic Review 82, no. 1 (1992).

Little Bird 小小鸟. 《关于我们》[About Little Bird]. 北京 [Beijing]: 小小鸟打工互 助 热 线 [Little Bird Labour Help Hotline] http://www.xiaoxiaoniao.org.cn/index.htm, 2008.

Liu Zenghui 刘增辉. "就业歧视--大学生心中永远的痛" [Discrimination in Finding Employment: The Never-Ending Pain of University Students]. 《教育与职业》 [Education and Vocation], no. 1 (2007).

Lu Yilong 陆益龙. 《户籍制度: 控制与社会差别》[The Huji System: Control and Social Disparity], 社会图像从书 [Social Images Series]. 北京 [Beijing]: 商务印 书馆 [The Commercial Press], 2003.

—_— . 1949 年后的中国户籍制度: 结构与变迁" [Structure and Transition: The Household Registration System in China after 1949]. 《北京大学学报（哲学 社会科学版) 》[Journal of Peking University (Humanities and Social Sciences)] 39, no. 2 (2002).

—. 《超越户口: 解读中国户籍制度》 [Transcending Hukou: Making Sense of China's Huji System]. 北京 [Beijing]: 中国社会科学出版社 [China Social Sciences Press], 2004.

Luyn, Floris-Jan van. A Floating City of Peasants. New York: The New Press, 2008.

Ma, Laurence J. C., and Chusheng Lin. "Development of Towns in China: A Case Study of Guangdong Province." Population and Development Review 19, no. 3 (1993).

Ma, Rong. "Han and Tibetan Residential Patterns in Lhasa." The China Quarterly no. 128 (1991).

Mallee, Hein. "Migration, Hukou and Resistance in Reform China." In Chinese Society: Change, Conflict and Resistance, edited by Elizabeth J. Perry and Mark Seldon. New York: RoutledgeCurzon, 2000.

Mao, Zhipeng, and Bo Ren. "Closure of Migrant Children Schools Exposes Education Deficiency." http://www.caijing.com.cn/20071225/43075.shtml, 2004.

Mason, T. David. "Modernization and Its Discontents Revisited: The Political Economy of Urban Unrest in the People's Republic of China." The Journal of Politics 56, no. 2 (1994).

Massey, Douglas S., Joaquin Arango, Graeme Hugo, Ali Kouaouci, Adela Pellegrino, and J. Edward Taylor. "Theories of International Migration: A Review and Appraisal." Population and Development Review 19, no. 3 (1993).

McNeill, William H. "Human Migration in Historical Perspective." Population and Development Review 10, no. 1 (1984). 
Meng Xiuqin 孟秀勤, and Shi Shaoqin 史绍洁, eds. 《北京人才工作报告》[Beijing Talent Employment Report]. 北京 [Beijing]: 中国人民大学出版社 [Renmin University of China Publishing], 2007.

National Bureau of Statistics of China. China Statistical Yearbook 2007. Beijing: China Statistics Press, 2007.

. "People's Republic of China Yearbook." Beijing: National Bureau of Statistics of China, 2001.

National Bureau of Statistics of China Department of Population and Employment Statistics 国家统计局人口和就业统计司, ed. 《中国人口和就业统计年鉴 2008》[2008 China Population and Employment Statistics Yearbook]. 北京 [Beijing]: 中国统计出版社 [China Statistics Press], 2008.

National Bureau of Statistics of China Department of Population and Employment 国家 统计局人口就业司. 《2005 中国人口》[2005 China Population]. 北京 [Beijing]: 中国统计出版社 [China Statistics Press], 2006.

Naughton, Barry. The Chinese Economy: Transitions and Growth. Cambridge: MIT Press, 2007.

Naughton, Barry J. Growing out of the Plan: Chinese Economic Reform, 1978-1993. Cambridge: Cambridge University Press, 1995.

Ngai, Pun. "Women Workers and Precarious Employment in Shenzhen Special Economic Zone, China." Gender and Development 12, no. 2 (2004).

Nielsen, Ingrid, Chris Nyland, Russell Smyth, Mingqiong Zhang, and Cherrie Jiuhua Zhu. "Which Rural Migrants Receive Social Insurance in Chinese Cities?" Global Social Policy 5, no. 3 (2005).

Nielsen, Ingrid, Russell Smyth, and Marika Vicziany, eds. Globalisation and Labour Mobility in China. Victoria: Monash University Press, 2007.

Nolan, Peter. Transforming China: Globalization, Transition and Development, Anthem Studies in Political Economy and Globalization: Anthem Press, 2004.

O'Brien, Kevin J. "Discovery, Research, (Re)Design and Theory Building." In Doing Fieldwork in China, edited by Maria Heimer and Stig Thogersen. Honolulu: University of Hawai'i Press, 2006.

People's Daily. "China to Make New Household Registration Law." People's Daily, http://english.people.com.cn/200502/24/eng20050224_174578.html, 24.02.2005.

Pomeranz, Kenneth. The Great Divergence: China, Europe, and the Making of the Modern World Economy. Princeton: Princeton University Press, 2000.

Ranis, Gustav, and John C. H. Fei. "A Theory of Economic Development." The American Economic Review 51, no. 4 (1961).

Rawski, Evelyn S. "Research Themes in Ming-Qing Socioeconomic History--the State of the Field." The Journal of Asian Studies 50, no. 1 (1991).

Research Directorate. "Issue Paper: China: Reforms of the Household Registration System (Hukou) (1998-2004)." edited by Immigration and Refugee Board of Canada, 2005.

Roberts, J. A. G. A History of China. 2nd ed. New York: Palgrave Macmillan, 2006.

Roberts, Kenneth D. "The Changing Profile of Labor Migration." In Transition and Challenge: China's Population at the Beginning of the 21st Century, edited by Zhongwei Zhao and Fei Guo. New York: Oxford University Press, 2007.

. "China's 'Tidal Wave' of Migrant Labor: What Can We Learn from Mexican Undocumented Migration to the United States?" The International Migration Review 31, no. 2 (1997).

. "Female Labor Migrants to Shanghai: Temporary 'Floaters' or Potential Settlers?" The International Migration Review 36, no. 2 (2002). 
—. "Rural Migrants in Urban China: Willing Workers, Invisible Residents." Asia Pacific Business Review 8, no. 4 (2002).

Rohlf, Greg. "Reproduction and State-Building Along China's Frontiers." China Information no. 21 (2007).

Rong, Jiajiao. "Hukou 'an Obstacle to Market Economy'." China Daily, http://www.chinadaily.com.cn/china/2007-05/21/content_876699_2.htm, 05-21 2007.

Schwarz, Henry G. "Chinese Migration to North-West China and Inner Mongolia, 1949-59." The China Quarterly no. 16 (1963).

Shanghai Daily. "Beijing to Aid Migrant Schools." China.org.cn, http://www.china.org.cn/english/government/180555.htm, 08.09.2006.

Shao, Sijun, Ingrid Nielsen, Chris Nyland, Russell Smyth, Mingqiong Zhang, and Cherrie Jihua Zhu. "Migrants as Homo Economicus: Explaining the Emerging Phenomenon of a Shortage of Migrant Labor in China's Coastal Provinces." China Information 27, no. 7 (2007).

Shenzhen Industry Information Website 深圳企业信息网。《中国户籍管理制度的变 迁》 [Changes in China's Huji Management System]. 深圳企业信息网 [Shenzhen Industry Information Website], $\leq$ http://www.smers.com.cn/site49/news 643.htm>.

Shenzhen City Public Security Bureau 深圳市公安局.《人口管理》[Population Management]. 深圳市 [Shenzhen]: 深圳市公安局 [Shenzhen City Public Security Bureau ] http://www.szga.gov.cn/4hzgl/index.asp, 2007.

Shih, Chih-yu "National Role Conception as Foreign Policy Motivation: The Psychocultural Bases of Chinese Diplomacy." Political Psychology 9, no. 4 (1988).

Smith, Kidder. "Sima Tan and the Invention of Daoism, "Legalism," "Et Cetera"." The Journal of Asian Studies 62, no. 1 (2003).

Solinger, Dorothy J. "China's Urban Transients in the Transition from Socialism and the Collapse of the Communist 'Urban Public Goods Regime'." Comparative Politics 27, no. 2 (1995).

- Contesting Citizenship in Urban China: Peasant Migrants, the State, and the Logic of the Market. Berkley: University of California Press, 1999.

-. "The Creation of a New Underclass in China and Its Implications." Irvine: Center for the Study of Democracy, University of California, 2005.

Standing Committee of the National People's Congress. "Constitution of the People's Republic of China." People's Daily Online, http://english.peopledaily.com.cn/constitution/constitution.html, 1982.

Steinmo, Sven. "Historical Institutionalism." Colorado University, 2007.

Streeck, Wolfgang, and Kathleen Thelen. "Introduction: Institutional Change in Advanced Political Economies." In Beyond Continuity: Institutional Change in Advanced Political Economies, edited by Wolfgang Streeck and Kathleen Thelen. New York: Oxford University Press, 2005.

Su Zhixia 苏志霞, and Wang Wenlu 王文录. "论户籍制度的功能定位" [A Discussion of the Function of the Hukou System ]. 《河北师范大学学报/哲学社会科学 版》 [Journal of Hebei Normal University/Philosophy and Social Sciences Edition ] 30, no. 2 (2007).

Tait, Arch. Russia--Lost in Transition : The Yeltsin and Putin Legacies. Washington, D.C.: Carnegie Endowment for International Peace, 2007.

The Central People's Government of the People's Republic of China 中华人民共和国 中央人民政府. 《户籍》[Huji]. 中国政府门户网站 [Chinese Government Internet Portal], http://www.gov.cn/banshi/gm/huji.htm, 2009. 
.《法律依据》[Legal Basis].中国政府门户网站 [Chinese Government Internet Portal], http://www.gov.cn/banshi/2005-05/30/content_2029.htm, 2009.

Thogersen, Stig, and Maria Heimer. "Introduction." In Doing Fieldwork in China, edited by Maria Heimer and Stig Thogersen. Honolulu: University of Hawai'i Press, 2006.

Tian Bingxin 田炳新. 《中国第一证件: 中国户籍制度调查手稿》[China's First Credential: China's Huji System Research Manuscript]. 广州 [Guangzhou]: 广 东人民出版社 [Guangdong People's Publishing House], 2003.

Todaro, Michael P. Internal Migration in Developing Countries: A Review of Theory, Evidence, Methodology and Research Priorities. Geneva: International Labour Organisation, 1976.

Tunon, Max. "Internal Labour Migration in China: Features and Responses." Beijing: International Labour Organisation, 2006.

UNdata: a World of information. "Gdp Annual Rate of Growth (World Bank Estimates)." United Nations Statistics Division, http://data.un.org/, 2008.

. "Gdp at Market Prices, Current Us\$ (Wb Estimates)." United Nations Statistics Division, http://data.un.org/, 2008.

. "Gdp in Current International Dollars (Ppps) (Wb Estimates)." United Nations statistics Division, http://data.un.org/, 2008.

Walton, Greg. "China's Golden Shield: Corporations and the Development of Surveillance Technology in the People's Republic of China." Quebec: International Centre for Human Rights and Democratic Development, 2001.

Wang, Fei-Ling. "Brewing Tensions While Maintaining Stabilities: The Dual Role of the Hukou System in Contemporary China." Asian Perspective 29, no. 4 (2005): 85-124.

- "China's Evolving Institutional Exclusion: The Hukou System and Its Transformation." In The Wellington Conference on Contemporary China 2009: Institutional Dynamics and the Modern Transformation of China, edited by Xiaoming Huang. Wellington: The New Zealand Contemporary China Research Centre, 2009.

- Organizing through Division and Exclusion: China's Hukou System: Stanford University Press, 2005.

Wang Fei 王飞, and Liu Wenhai 刘文海. "部分地方户籍制度改革情况调查报告" [Research Report on the Conditions of Reform of the Huji Institution in Selected Areas]. In 《中国农民工调研报告/国务院研究室课题组》[China's Nongmingong Research Report/Discussion Group of the Research Department of the State Council], edited by Wei Liqun 魏礼群 and Han Changfu 韩长赋. 北 京 [Beijing]: 中国言实出版社 [China Yanshi Press], 2006.

Wang, Feng, and Xuejin Zuo. "Inside China's Cities: Institutional Barriers and Opportunities for Urban Migrants." The American Economic Review 89, no. 2 (1999).

Wang Weihai 王威海. 《中国户籍制度：历史与政治的分析》[China's Huji System: A Historical and Political Analysis]. 上海 [Shanghai]: 上海文化出版社 [Shanghai Culture Publishing House], 2006.

Wei Liqun 魏礼群. "正确认识和高度重视解决农民工问题（代序言）" [Properly Recognising and Placing High Importance on Resolving the Nongmingong Issue (Preface)]. In《中国农民工调研报告/国务院研究室课题组》[China's Nongmingong Research Report/Discussion Group of the Research Department of the State Council], edited by Wei Liqun 魏礼群 and Han Changfu 韩长赋. 北 京 [Beijing]: 中国言实出版社 [China Yanshi Press], 2006. 
Wei Liqun 魏礼群, and Han Changfu 韩长赋, eds. 《中国农民工调研报告/国务院研 究室课题组》[China's Nongmingong Research Report/Discussion Group of the Research Department of the State Council]. 北京 [Beijing]: 中国言实出版社 [China Yanshi Press], 2006.

Wong, Daniel Fu Keung, Chang Ying Li, and He Xue Song. "Rural Migrant Workers in Urban China: Living a Marginalised Life." International Journal of Social Welfare no. 16 (2007).

Wong, Linda, and Wai-Po Huen. "Reforming the Household Registration System: A Preliminary Glimpse of the Blue Chop Household Registration System in Shanghai and Shenzhen." The International Migration Review 32, no. 4 (1998).

Wu, Saifeng, Xiaogu Song, and Bo Zeng. "Shenzhen: Lonestar of China's Reform and Opening-Up." Beijing: China Today, http://www.chinatoday.com.cn/English/e2008/e200812/p40.htm, 2008.

Wu, Weiping. "Migrant Housing in Urban China: Choices and Constraints." Urban Affairs Review 90, no. 119 (2002).

Wu, Xiaogang, and Donald J. Treiman. "The Household Registration System and Social Stratification in China: 1955-1996." Demography 41, no. 2 (2004).

Xiang, Biao. Transcending Boundaries : Zhejiangcun : The Story of a Migrant Village in Beijing. Translated by Jim Weldon. Boston: Brill, 2005.

. "Zhejiang Village in Beijing: Creating a Visible Non-State Space through Migration and Marketized Networks." In Internal and International Migration: Chinese Perspectives, edited by Frank N. Pieke and Hein Mallee. Cornwall: Curzon Press, 1999.

Xinhua News Agency. People's Republic of China Year Book. Beijing: Xinhua Publishing House, 2001.

Xinhua News Agency 新华社. 《商国是 谈履职一一记三位农民工代表的首次会 面》[Discussing Important Matters of the State ... Recording the First Meeting of Three Nongmingong Representatives]. 新华网 [Xinhua Online], http://news.xinhuanet.com/photo/2008-03/04/content_7714576.htm, 04.03.2008.

———. 《公安部等 14 个部委正协商户籍管理制度改革》 [Mps and 14 Ministries and Commissions Negotiating Huji Management System Reform]. 成都商报 [Chengdu Business News], 2008.

Xu Xueming 徐学明. 《进京户口完全手册》 [Manual to Enter Beijing Hukou]. 北京 [Beijing]: 法律出版社 [Legal Press], 2005.

Xu Zengyang 徐增阳."民工、民工问题与民工的 “终结” --国家治理视角的解读”

[Mingong, Mingong Issues and the 'End' of Mingong: A New Perspective on National Governance]. 《中共宁波市委党校学报》[Journal of the Party School of CPC Ningbo Municipal Committee], 29, no. 1 (2007).

Yan, Hairong. New Masters, New Servants: Migration, Development and Women Workers in China. Durham and London: Duke University Press, 2008.

Yan Wenhua 燕文华. "高考招生制度不平等拷问法律公平" [University Entrance Examination and Student Recruitment System Is Unequal and Questions the Impartiality of the Law]. 《牡丹江大学学报》[Journal of Mudanjiang University ], 16, no. 4 (2007).

Yang, Dennis Tao. "Urban-Biased Policies and Rising Income Inequality in China." The American Economic Review 89, no. 2 (1999).

Zhang Hengshan 张恒山。"关于公民迁徙自由的立法" [Legislation Regarding Freedom of Migration ]. In 《庆祝中德建交三十周年 “中国与 WTO” 研讨会, 慕尼黑对话》[Celebrating 30 Years of Diplomatic Relations between China 
and Germany, 'China and the WTO']. 慕尼黑 [Munich]: 汉斯 - 赛德尔基金会 共同举办 [Hanns Seidel Foundation], 2002.

Zhang, Kevin Honglin, ed. China as the World Factory, Routledge Studies in the Growth Economies of Asia. New York: Routledge, 2006.

Zhao, Shukai, and Andrew Kipnis. "Criminality and the Policing of Migrant Workers." The China Journal no. 43 (2000).

Zhao, Yaohui. "The Role of Migrant Networks in Labor Migration: The Case of China." Contemporary Economic Policy 21, no. 4 (2003).

Zhao, Zhongwei, and Fei Guo, eds. Transition and Challenge: China's Population at the Beginning of the 21st Century. New York: Oxford University Press, 2007.

Zheng, Yongnian. "Political Incrementalism: Political Lessons from China's 20 Years of Reform." Third World Quarterly 20, no. 6 (1999).

Zhong Liang 钟良. “深圳户籍体制变革 “一市两制”户籍管理终结” [Shenzhen Huji System Transformation: 'One City Two Systems' Huji Management Structure]. 《21 世纪经济报道》[21st Century Business Herald], 2008.

Zhou, Daming. How the Farmers Changed China: Power of the People. Boulder: Westview Press, 1996.

Zhou, Xueguang, and Liren Hou. "Children of the Cultural Revolution: The State and the Life Course in the People's Republic of China." American Sociological Review 64, no. 1 (1999).

Zhu Konglai 朱孔来, and Li Hongze 李洪泽. "城市化与城镇化的区别和联系" [Distinguishing and Relating Chengshihua and Chengzhenhua], 《时代金融》 [Times Finance], no. 5 (2006). 